Historic, archived document

Do not assume content reflects current scientific knowledge, policies, or practices. 


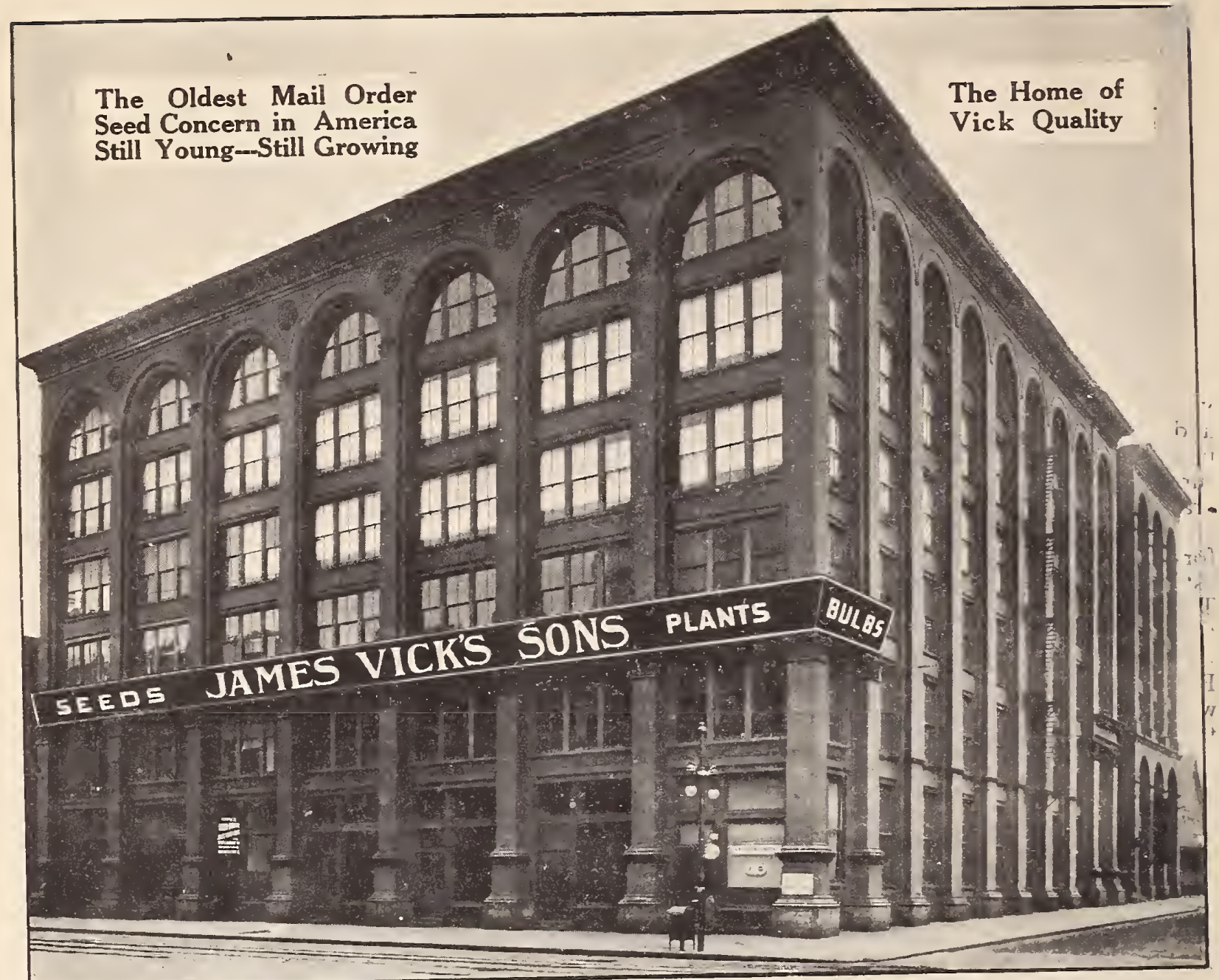

Here, in one of the finest buildings in this city, we are so situated that we can handle more orders with better care and greater speed than ever before. Except under unusual circumstances, all orders will be filled within a few hours of their cumstances, all Every department is in the hands of efficient superintendents of wide experience and thorough knowledge of the business.

\section{CONVENIENCE IN ORDERING}

Remember at the prices named in this catalogue, we send Seeds, Bulbs and Plants to any part of the United States, postage or express prepaid, unless otherwise stated. No inconvenience or delay. Simply fill out our order blank carefully, giving full post-office address and the name of the nearest express station, and enclose your remittance. Your order will be filled promptly and with the best quality stock. We guarantee its safe arrival at your express or post-office address. Therefore, no matter where you live, it is just as easy and safe to order of us as if you lived next door. No Goods Sent C. O. D.

\section{SAFETY IN SENDING MONEY}

Money may be sent at our Risk and Expense if forwarded according to any of the following methods:

1. Post-Office Money Order, which is the most popularway.

2. Express Money Order.

3. New York or Chicago Draft.

4. Registered Letter.

We disclaim responsibility for all other forms of remittances.
Our seed house is daily receiving stocks either from our own farms or those of other growers, each of whom makes a specialty of growing a few good things; or from some of the famous seed growers of Europe. Our greenhouses are filled to the doors with plants of every kind, while our root cellars are packed with bulbs and dormant plant stock, all waiting for your spring orders.

1. We prepay postage or express rates, unless otherwise noted, on all shipments to any part of the United States or Canada.

2 . If you have occasion to refer to a previous order, placed with us, be sure to mention the post-office to which the goods were shipped, the post-office from which the order was mailed, and give the same name as in the first order.

3. On account of risk from cold weather, orders for plants will be held until about April first. In case they are wanted at an earlier date, mention that fact and they will be shipped accordingly, in which case, however, we do not assume responsibility for damage from cold weather.

4. Unless otherwise instructed we will ship the best and cheapest way, whether by mail or express. Therefore, you should mention both your post-office address and your express station.

5. We do not pay export duties.

6. Customers ordering seeds by express or freight, should promptly advise us in the case of delay or overcharges on shippromptly advise us inilar matters. Very frequently we are able ments or in other similar matisfactory to all concerned. Our services are always at your command. 
EOR a number of weeks we have been working over the material for every page of the $191+$ edition of our Garden and Floral Guide, reducing, condensing, leaving out some varieties which may possibly be spared, in an effort to prepare roum for a large number of thoroughly tested new varieties which deserve a place in our Vick Quality List.

There is much more we want to say but it is out of the queston to pack more into our Garden and Floral Guide this year. We sincerely believe it is the best book we have ever issued. We are certain that our customers and friends will find each page interesting whether yo.1 turn to the plants and bulbs or the flowers an 1 vegetables. The best thing we have to say in the little space we have left is that our stocks s..pass, if that is possible, in all around genral excellence any we have heretofore offered.

This house was founded sixty-five years ago the purpose of growing and selling the newc and best varieties of seeds, plants, and bulbs. his was the first mail order house in any line of business to be established in America. It was the first seed concern to catalogue Sweet 'eas, the first to introduce many other now vell known varieties. It was the first to realize the commercial value of the Aster, which is now conceded to be the leading mid-summer annual. While some of the old varieties in common use thirty or forty years ago are still in demand today, every year finds. a large list of new and better types. Consequently every year the field of our operations grows in size and in importance.

It has always been the aim of this concern not so much to sell the largest quantity as to sell the best quality the earth produces. Our customers may rest assured, therefore, that their orders, whether large or small, will receive from us the best care and attention our long experience and wide knowledge of conditions enable us to give.

For the large measure of success we have attained, and the confidence in which our seeds are held from coast to coast, in fact, in every corner of the civilized world, we are profoundly grateful. It is our hope and belief that every purchase from this catalogue will not only spread the popularity of our goods, but add to the happiness and prosperity of every purchaser.

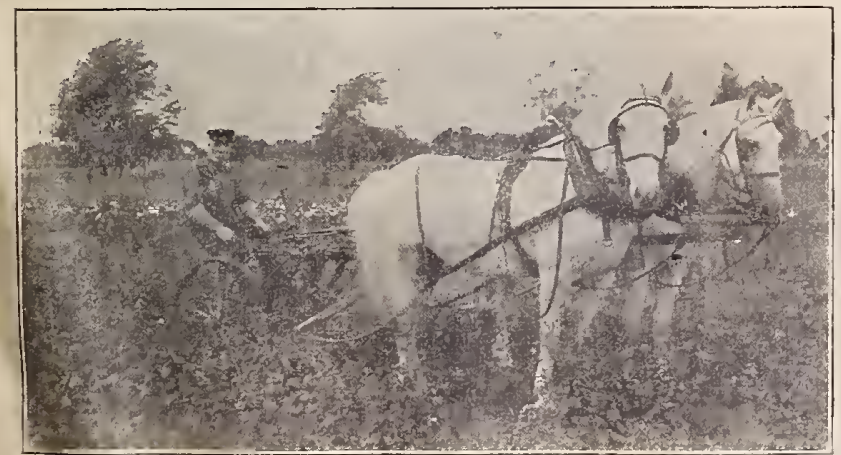

January 24,1870 , just forty-four years ago, James DeForest, then a mere boy, began working for James Vick, the founder of this concern. During all of the years since then he has continuously and faithfully worked for the "Vick" interests. Forty-four years is a long time in the life of any man, but there is not a man anywhere who can do a better job of plowing, or plant a straighter row.

One of these "colts" is twenty-six years old; the other is eighteen. Both are "sound as a dollar," and have been in the harness more days every year than any other team on our farms, which speaks volumes for Mr. De Forest's care. It is a pleasure to us to express in this public way our appreciation of the faithfulness and long service of this, our oldest employee.

We like to think that the faithfulness and loyalty of the men and women connected with this house have had much to do with its success.

Vick's Garden and Floral Guide, Copyrighted, Igr4, by James Vick's Sons, Rochester, N. Y. 


\section{NOVELTIES AND SPECIALTIES}

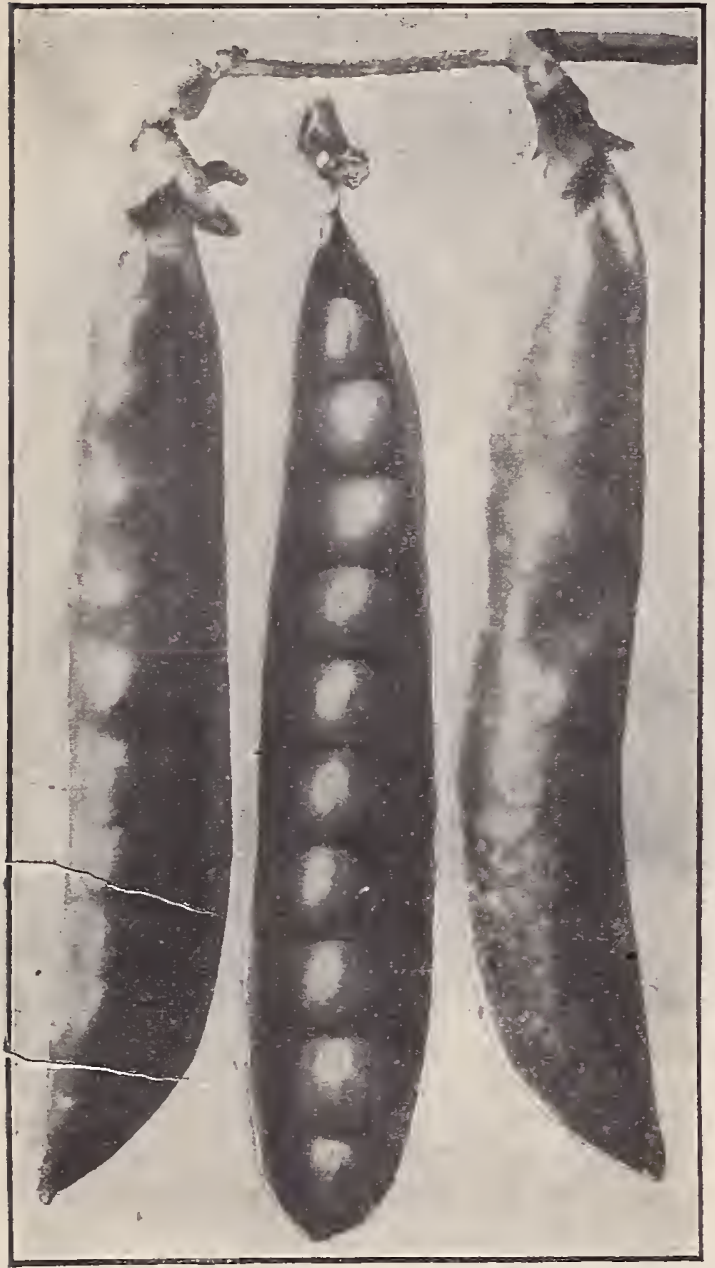

THE HARVESTER

A magnificent new medium early $\mathrm{Pea}$ of very high quality, and especially valuable on account of its enormous yield. The dark green pods are very large, borne in pairs, and are filled with peas of delicious flavor. Last season it nutyielded all of the standard varieties in our trial ground. The vines are very stout and grow from eighteen inches to two feet in height; they are hearily loaded with the handsome, well-filled pods.

Packet, 15 cents; $1 / 2$ pint, 25 cents; pint, 40 cents.

\section{The Best Early Cabbage}

Copenhagen Market. (Page 12). The large, solid heads are tender and fine srained. It is a thoroughbred variety, remarkably nniform in size and season, and every head marketable.

Packet, Io cents; $1 /+$ ounce, I5 cents; ounce, jo cent; ; $1 / 4$ pound, $\$ 1.40$; pound, $\$ 5.00$.

\section{Vick's Three Weeks Radish}

\section{A New Forcing Radish of Great Value}

\section{Extremely Early. Brilliant Color. Small Top and Tap Root.}

Tick's Three Weeks Radish can be gro:n, ready: for the table, in less than three weelis from the day of suring the seed. The root begins to develop with the development of the first leares. This new Radish has a color quite distinctive, a light, fiery scarlet, giving it a very altractive appearance in the market or on the table. Tick: Three Weeks has a small top, even for an early Radish, and a remarkably slender tap-root. This is well shown in the illustration below. Vick's Three Weeks Radish is perfectly round and grows to a nniform size; in fact, it is remarkably uniform both in size and in shape. As a forcing Radish we bave found Vick's Three Weeks all that could be desired. Solid, crisp and tender. Equally valuable for the garden.

Vick's Three Week's Radish is entirely distinct from any Radish heretofore offered. As an all-round Radish we do not think it can displace Vick's Scarlet Globe; but it has sterling qualities of its own that will give it a permanent place in the list of best Radishes. We urge our customers to give it a trial.

Packet, I5 cents; five packets, 65 cents.

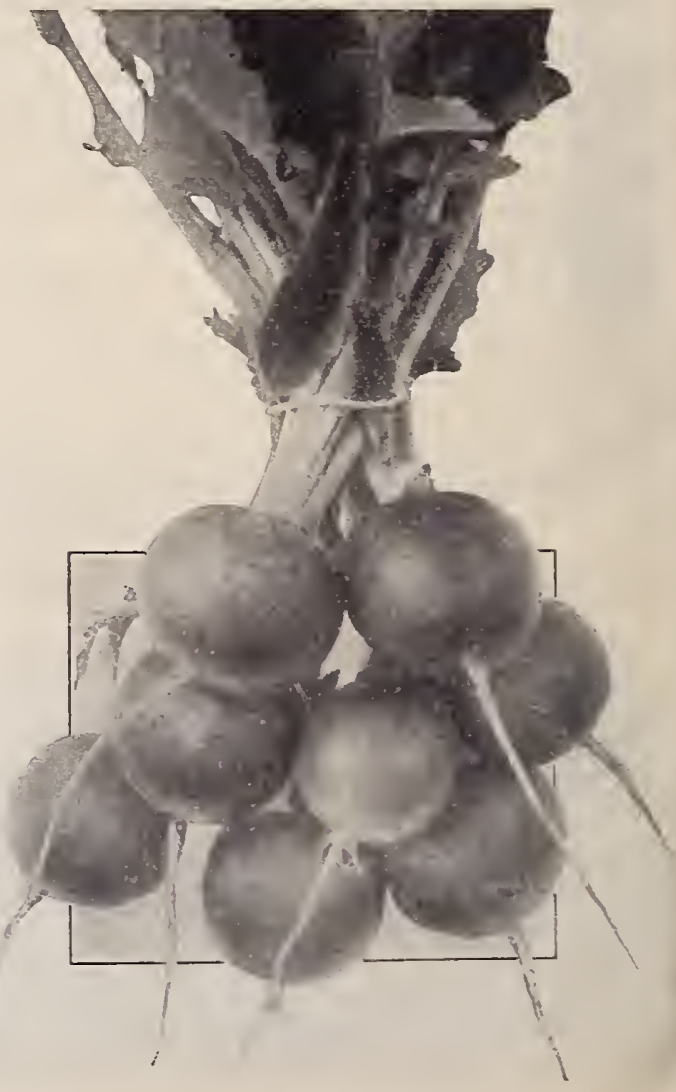




\section{ROCHESTER WHITE} THE BEST WHITE GLADIOLUS

The Rochester White originated about five years ago with a wellknown firm of commercial florists, within the city limits of Rochester, and the bulbs have all been grown by them.

The flower is a beautiful clear white throughout. It has no markings in the throat and even the anthers are white. The large, broadly opened biooms have nicely rounded petals, well arranged in an ample spike three feet in height. They form bulbs of good size which produce strong, heálthy plants, comparing well in size and vigor with any of the standard varieties.

There has never been any question among those familiar with this Gladiolus about the great merit of Rochester White; but the introductory price of $\$ \mathbf{I} .00$ for a single bulb was so high as to discourage its general introduction. By a special arrangement with the originators, we are now able to offer this splendid Gladiolus at a price within the reach of all lovers of Gladioli.

Igro. The Rochester White was first shown, not in competition, at the American Florists' Convention in Rochester, I9lo, where it attracted much favorable' comment.

I9I 1. August I5-I8, American Gladiolus Society, Baltimore.

First Prize, for 6 best spikes of any White variety.

First prize for 25 best spikes of any White variety.

\& Sons, Rochester, N. Y., had a small but notable exhibit at Baltimore, MId., of Gladiolus blooms, an unnamed White Seedling of their own raising, took several prizes; was thought by many to be the best White in sight today. It looked particularly well with a vase of Europa, the German white, that sold for \$2.50 per bulb." - The Florists' Reviezw, August 17, 1911.

"This new White Seedling Gladiolus unnamed, at the Baltimore Convention, but in the future to be known as 'Rochester White, has certanly every indication of proving a gond commercial sort. The spikes of very large blooms are welt supported on strong, straight stalks which carry also broad green foliage."-The Florists' Exchange, September. $9,1911$.

I gI I. August 27, New York Horticultural Society, N. Y. Botanical Gardens, Bronx Park. First Prize for 25 spikes of best White. IgI2. N. Y. State Fair, Syracuse, N. Y. First Prize for best White. IgI3. N. Y. State Fair, Syracuse, N. Y. First Prize for best White.

Each. 40 cents; three for $\$ 1.10$; six for $\$ 2.00$; dozen, $\$ 4.00$.

\section{Tomato}

Vick's Improved Earliana. (Page 37). This valuable Tomato has been one of our specialties for several years. The seed we offer was grown on our own farm and zee know that it is right. Packet, ro cents ; half ounce, 25 cents ; ounce, 40 cents ; qualter pound, $\$ 1.25$; pound, $\$ 4.00$.

\section{Summer Asparagus}

The Summer Asparagus, introduced by tus in 1912, is fully described on page 34. The name "Summer Asparagus," was applied to this vegetable on account of its fancied resemblance in flavor to the ordinary garden Asparagus. One of the most delectable vegetables that has been introduced in years.

Packet, I5 cents; ounce, 75 cents.

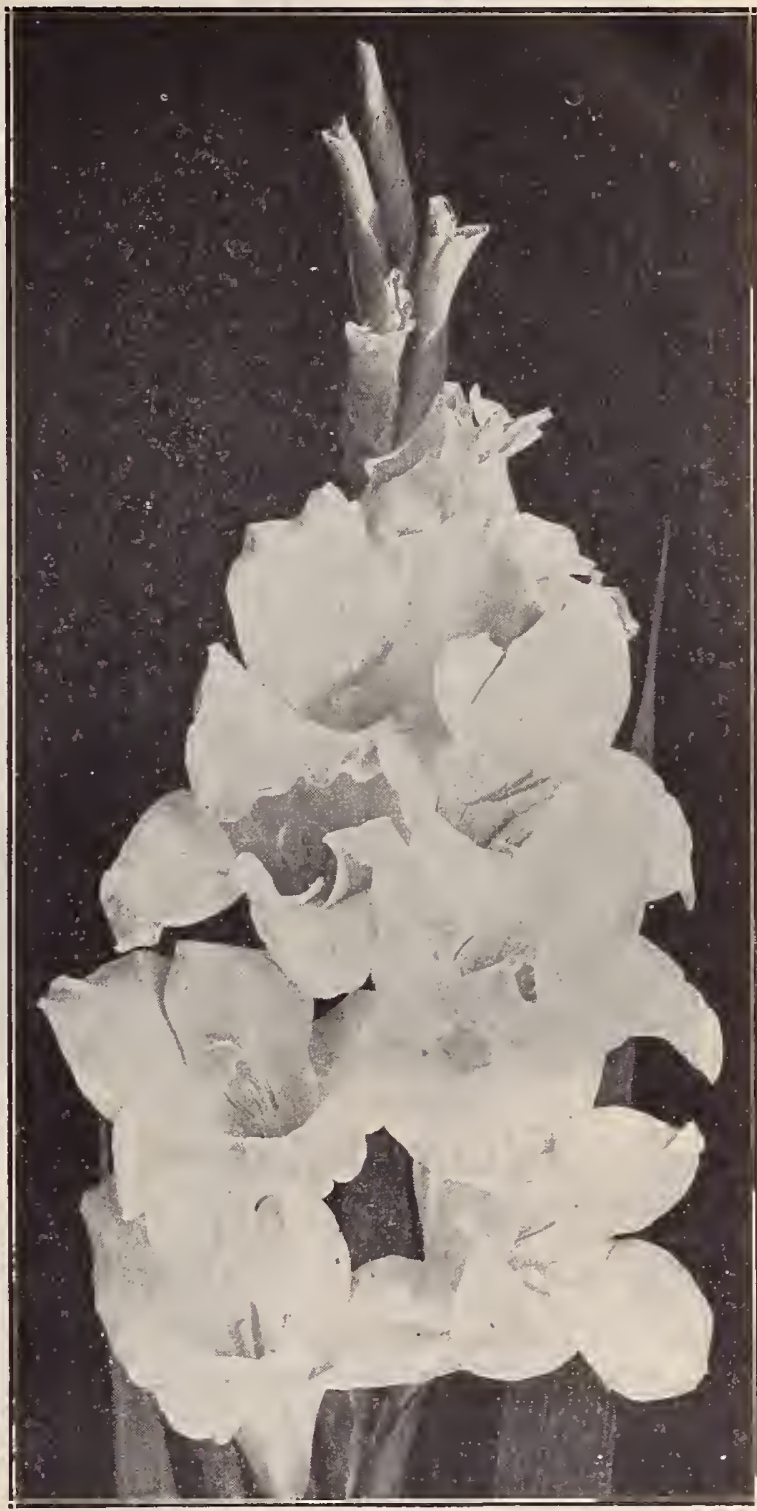

THE ROCHESTER WHITE GLADIOLUS

\section{Muskmelon.}

Vick's Irondequoit. (Page 23). Do not omit this from your list of good things for the garden. We have tried every Muskmelon that has been offered since we introduced Irondequoit, and we have never found one that, in our opinion, was its equal,

Packet, ro cents; $1 / 2$ ounce, 30 cents; ounce, 50 cents $1 / 4$ pound, $\$ 2.00$; pound, $\$ 7.50$.

It is our idea in these novelty pages simply to call your aitention to a few of the leading vaiteties with which every grower should become familiar. Please do not get the impression that these varieties are necessarily better under all circumstances than many other varieties listed in the body of this Guide. It is our belief that every variety in this catalogue is the, best for the purpose for which it is intended, because we use all possible care to secure the best grade of each variety.

When we use the expression "Vick Quality, the Best the Earth Produces"

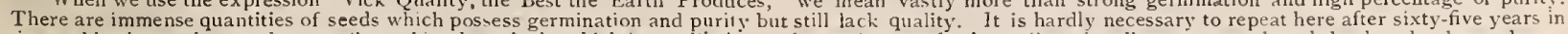

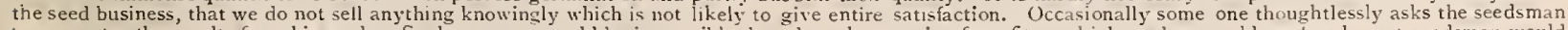

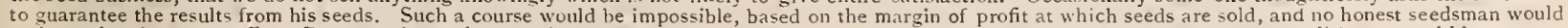

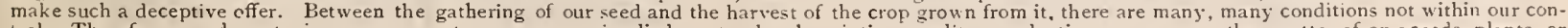

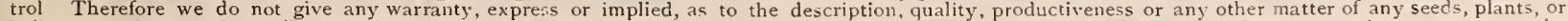

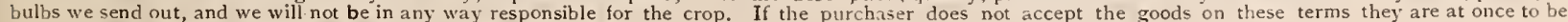
retumed, and the price paid for same will be refunded. 


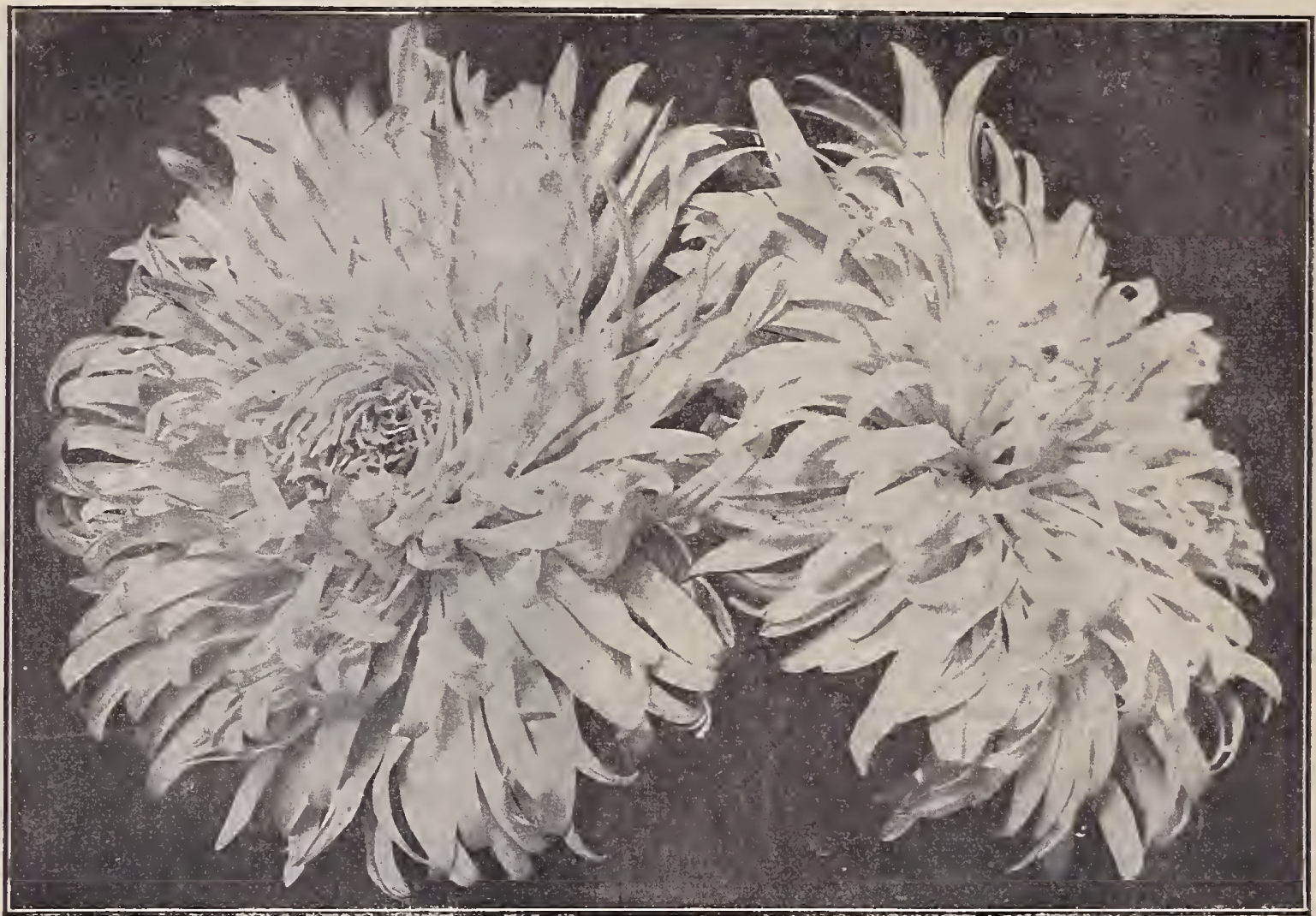

\section{Triumph Comet}

A magnificent new class of midseason Aster. They come into bloom at about the same time as the Imperial class, remaining in lsloom a long time. The plants are upright, about two feet in heiglit, and crowned with immense flowers of the finest Comet troe. Splendid flowers for cutting, having very long stems, and the beautiful feathery flowers lasting well when cut

White, Shell Pink, Lavender, Rose and Purple.

Packet, 25 cents; two packets, of one variety, for 40 cents. The set of five colors, 51.00 .

\section{Vick's Autumn Glory}

\section{Illustration on Front Cover}

Pure sea-shell pink. While similar in color to Semple's Pink, with which most growers are familiar, it has a better and more substantial flower, a deeper and longer lieeping color,

larger and stronger type of plant. Its most distinctive charact eristic and chief claim for recognition, however, is the fact that it is later in season than any of the other varieties. Whsle it camnot take the place of uthers of similar color, which are earlier, it supplements them by bloming after the other Late Asters are.past their prime, and before the early Clirysanthemums are ready, thus prolonging the Aster season two weeks, and coming at a time. when good fowers are extremely scarce. Vick's Autımn Glory will be a money-maker for the commercial grower, and a delight to the amateur. It comes uniformly true to color and type. The flowern are very dnulsle and are lome on stems of unusual length. Packet, 25 cenis; two for 40 cents.

\section{Shell Pink Perfection Rose Perfection}

The flowers of these two new colors in the beautiful Perfection class have the same strongly whorled, incurved type as those of the Blush Perfection, introduced in IgI3, and the plants also have the same tall, slender, very long stemmed habit. Many of our New York State friends will recall seeing, in our exhibit at the 1913 State Fair, a vase of Rose Perfection, at that tine not yet named; beautiful, bright rose-colored flowers, with a pronounced twist to the petals, Packet, either color, 25 cents; two for 40 cents.

\section{Non-Lateral Rochester}

The flowers are borne stifty erect and are more clouble than those of the original Rochester, while the color is the same charming shade of lavender pink. They have a remarkable thickness and are without any trace of a center. About one week earlier than the original, or branching type of Rocliester. Packet, 25 cents; two for 40 cents.

\section{Vick's Lavender King}

The massive flowers of the new Laventer King are of the same thick, flutfy type as those of the White King. The color is a very pleasing shade of deep Lavencler. We offer Lasender King in two types - with brancling or with upright plants.

Lavender King. Brancling type, pkt., 25 cะn:s.

Lavender King. Upright type, plit.,25 cen:s. 


\section{SWEET PEAS}

\section{FOUR GRAND NEW SPENCERS}

King White has every requisite of a perfect Sweet Pea. The flower has inmense size, a bold expanded form splendid sub. stance and is exquisitely frilled. It has long stems, a large proportion of which carry four blossoms. When we add to this that the vine ia a vigorous grower and a free bloomer, we think that you will agree that it would be difficult to imagine any improvement on King White.

Packet of 15 seeds, 15 cents. Packet of 30 seed, 25 cents.

Illuminator. A new and wonderfully striking color in Sweet Peas. Illuminator is a combination of shades, producing, under artificial light, a color effect of glowing orange scarlet. The ground color of salmon orange, shining through the rich cerise-pink with which it is overlaid, gives a delightfully rich effect. Our printed description conveys but a faint suggestion of the glowing beauty of this rare combination of unusual shades.

\section{Pkt., of I 5 seeds, I 5 cts.} Fkt., of 30 seeds, $2 j \mathrm{cts}$.

Margaret Atlee. A rich shade of salmon pink overlaid on a background of cream color. A charming shade that is unlike any other pink in Sweet Peas. The flowers are very large and most of them have double standards. A mag. nificent new Spencer in the desirable creamy pink class.

Small packet, I 5 cents. Regular size packet, $25 \mathrm{cts}$.

Elfrida Pearson. Huge flowers of a dainty light pink, an extremely delicate shade. The buds and the opening flowers show a light salmon tint. One of the most vigorous and free-llooming varieties. The immense flowers are almost invariably borne four on a stem and many of them have clouble standards.

Small, packet, I5 cents. Regular size packet, 25 cents.

\section{Vick's Extra Early Cosmos}

The Cosmos has long been a general favorite, because it is so admirably adapted for use as a cut flower. The flowers are large with a beautiful silken texture; they are borne on long stems and the foliage is beautiful and feathery; making them exceedingly useful for decorating. In the Noth, however, unless plants are started in a hot bed, the Cosmos blooms so late that it is often caught by an early frost before it has begun flowering. Vick's Extra Early Cosmos will come into bloom early in July from seed sown in the open ground in May, thus giving us a long season of these beautiful flowers. Packet, mixed colors, 15 cents.

\section{PELARGONIUM}

\section{Lady Washington Geranium}

\section{The New Everblooming Pelargoninm, Easter Greeting}

The flowers of Easter Greeting have the large size and the gorgeously rich coloring of the "Lady Washington Geranium." To this is added, in Easter Greeting, the habit of continuous blooming, which has made the ordinary bedding geranium so highly valued. Easter Greeting is the first of a new race and one of the most valuable introductions in recent years. An an Easter plant it rivals the Azalea; but unlike the Azalea, Easter Greeting, will continue in full bloom all summer Each, 25 cents; dozen, $\$ 2.50$.

\section{Ivy-Leaved Nasturtiums}

The beautiful foliage of this distinct, new class of Climbing Nasturtiums, closely resembles that of the old English Ivy, the thick angular leaves having a very dark glossy green color. The petals of the flowers, which do not overlap as do those of the other classes, are prettily fringed. The brilliant flowers make a striking contrast with the dark leaves.

Princess Juliana. $\mathrm{R}$ ich golden orange; blotches of red brown. Packet, 1o cents; ounce, 25 cents.

Emma Alida. Golden yellow and orange; deep scarlet blotches. Packet, ro cents; ounce, 25 cents.

\section{New Deutzias}

The Deutzias are among the most satisfactory of all our Hardy Flowering Shrubs. They are extremely hardy; succeed well in any situation; have a neat, desirable habit of growth, and are profuse bloomers. Two fine new varieties, Deutzia crenata latifolia, and Deutzia crenata magnifica are described on page 83 . Each $50 \mathrm{cts}$.

\section{Hybrid African Daisy Beautiful New Colors}

A graceful and charming new class of annnal flowers. These new Hybrids are a great improvement over the original African Daisy, Dimorphotheca aurantiaca. They are very easily grown, coming into bloom quickly from seed sown in the open ground, and continuing to bloom profusely until after hard frosts. The colors rangre from white to orange, but are mostly delicate shacles of salmon and primrose. The plants grow in a spreading form and the graceful flowers are borne well above the foliage. Free blooming, easily grown, bearing graceful flowers of charming colors, Hybricl African Daisy is sure to become a popular plant, adapted to many places and a great variety of purposes.

Packet, mixed colors, 15 cents. 


\section{ASPARAGUS}

As Asparagus seed germinates very slowly, it is advisable to pour hot water over it. When cool, pour off the water and treat it again with hot water. Sow sied qujte early in spring, in a bed of light, rich, well-manured soil, in drills ore foot apart and two inches deep. When the plants are well up, thin to sout ane inch ápart. When the plants become withered, cut them down, and spread weil-rotted stable manure two inches deep over the bed. Let the plants remain in tbe seedbed until they are about to grow, early in spring. The subsoil of the permanent bed sbould be $\mathrm{dry}_{\mathrm{r}}$, and if not so, it must be well drained. It should be dug thoroughly at least two and one-half feet deep, and mixed with plenty of welt rotted manure. For private garden use set the plants in rows two feet apart, and about a foot apart in the row, with crowns four inches below the surface, and spread the roots. For field culture the rows sbould be six feet apart and two feet apart in the rows. Before winter cover the transplanted beds with about four inches of manure, and fork it in the next spring, being carefiul to not injure the roots. In autumn, cut the ripe tops and burn the refuse. One pound of seed will produce plants sufficient for an acre, and one ounce of seed will sow a drill fifty feet long.

Vick's Mammoth is, without exception, the Inrgest, heariest and best Asparagus gromn.

A bunch of twelve stalks will weigh three to four pounds. In size, color and yield, it far surpasses any other variety. The delicacy of its color notably distinguishes it from other green varieties, while its thick stalks are unusually tender and succulent and of delicious flavor.

Packet, 5 cents; oz., Io cents; $1 / 4$ lb., 30 cents; $1 \mathrm{~b}$., $\$ 1 . \infty$.

Conover's Colossal. The old standard variety; of large size, rapid growth, and of best quality.

Ounce, 5 cents; $1 / 4 \mathrm{lb}$., I5 cents; $1 \mathrm{~b}$., 50 cents.

Palmetto. Of Southern origin, but equally adapted for North or South. Early, large, productive, and of excellent quality.

Packet, 5 cents ; oz., ro cents ; $3 / 4 \mathrm{lb}$., 20 cents ; $1 \mathrm{~b} ., 60$ cents.

Columbian Mammoth White. A variety, producing white stalks of large size and finest quality and favor.

Packet, 5 cents ; oz., Io cents ; 1// lb., 25 cents; 1b., 75 ceats.

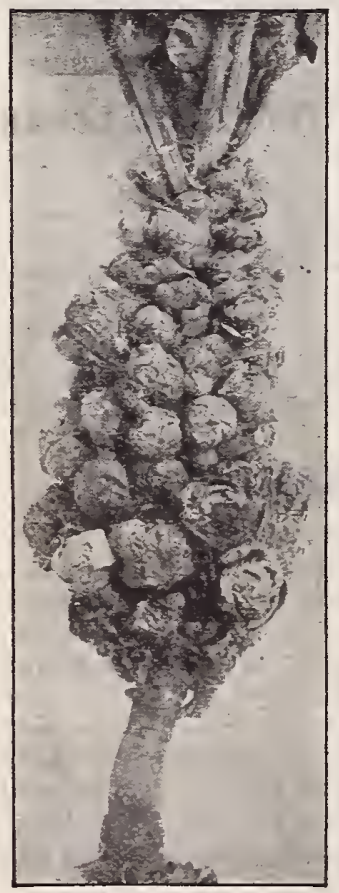

BRUSSELS SPROUTS

\section{Asparagus Roots}

By purchasing plants at least a year of time is saved. The young sboots may be cut for the table the second season. A bed $8 \times 27$ feet, requiring roo plants will supply an ordinary family.

Vick's Mammoth. StRoNg TwO-YEAR Roots-Ioo, by mail, prepaid, \$1.50. By express or freight, not prepaid, per 100,\$I.00; per $1000, \$ 6.00$.

Conover's Colossal. Strong Two-year Roots-ioo, by mail, prepaid, \$r.25. By express or freight, not prepaid, per Ioo, 75 cents ; per $1000, \$ 5.00$.

\section{Brussels Sprouts}

Brussels Sprouts are hardier than cabbages, and the "sprouts," or little heads growing along the stem are considered the most delicately flavored vegetables of the entire Cabbage family. Grown in the same manner as winter Cabbage. The late crop is usually the most satisfactory. One ounce of seed will produce about 5,000 plants.

Improved Dwarf. Packet, 5 cents; oz., 25 cents; lb., \$2.50.

Asparagus
Roots
Home
grown
Aspara-
gus is
superior
in flavor
and ten-
derness
to that
purchas-
ed at the
market.
Strong
two-year-
old from
seed give
the best
satisfac-
tion, pro-
ducing
an earlier
and more
abundant
crop than
either one
or three-
year old
roots.
After plant-
ing, the bed
will last for
years.

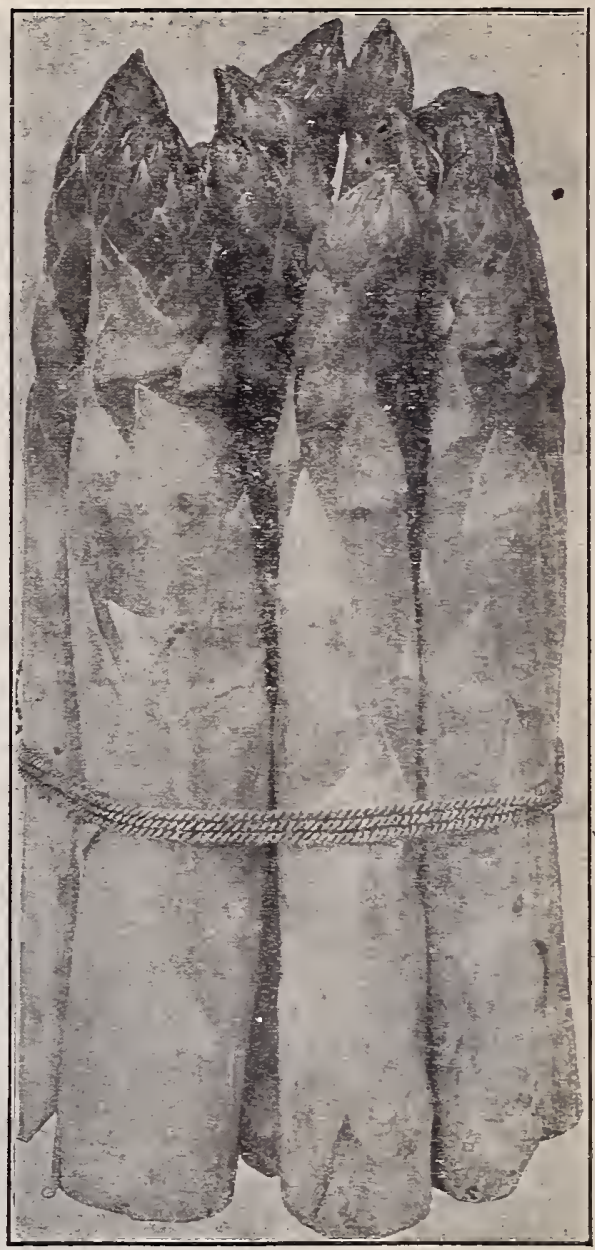

ASPARAGUS, VICK'S MAMMOTH

\section{ARTICHOKE}

The Globe Articboke is cultivateo for its flower heads, which are used in an undeveloped state, cooked like Asparagus. Plant seed early in spring, three inches apart, in rows one foot apart. When one year old, transplant to rows three feet apart and one foot apart in the row. Where the winters are severe protect the plants with leaves or dry litter, to keep the crowns from freezing. Green Globe. (Seed). Packet, ro cents; 0z., 35 cents; 1b., \$3.5०. Jerusalem. (Tubers). See Farm Seeds, page 42

\section{BORECOLE OR KALE}

A hardy plant of the Cabbage family, of easy culture, extensively grown for greens. Sow seed early in June and transplant. Culure same as for Cab. bage. One ounce will sow 300 feet of drill.

Packet, 5 cents ; oz., ro cents; $1 \mathrm{~b} ., \$ 1.00$.

Tall Green Cùrled Scotch. Finely curled : verg hardy; one of the best.

Dwarf Green Curled Scotch. Dwarf, beautifully curled, and bright green; hardy, and may be cut from the ground all the early 'art of winter. 


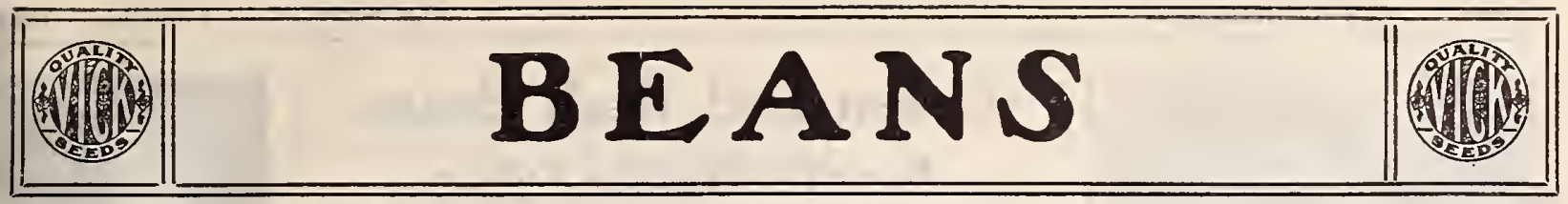

THE Dwarf Beans are earliest and most hardy, as a general rule. In garden culture, Beans are usually planted about two inclies deep, in rows eighteen inches apart, and three inches apart in the row; in field culture, in drills two to three feet apart, so as to cultivate with horse one way. Until blossoming season, frequent but shallow cultivation should be given. Seed of the large varieties should be planted with the eye downward. One quart of seed will be sufficient for 100 hills of Limas, and 250 to 300 hills of the other varieties, and for about too feet of drill. Sow one bushel per acre.

For prices on larger quantities, by express or freight. see page 9. Special prices to commercial growers on application.

\section{Yellow or Wax-Pod Bush Beans}

Brittle Wax. Eury, Productive, Tender, and of Extru Fine Quality. Stringless and crisp. Pods round, a rich golden yellow, five or six inches long. In comparison witb otber varieties on our trial grounds, it bas proved itself to be a superior sort.

Packet, Io cents ; $1 / 2$ pt., 20 cents ; pt., 30 cents ; qt., 55 cents.

(Illustration on page 9)

Wardwell's Kidney Wax. This variety is very hardy, extremely prolific, producing a heavy crop of long, flat pods, of a delicate waxy yellow stringless and brittle. The Beans are large and kidney-shaped.

Packet, ro cents; 1/2 pt., 20 cents ; pt. 30 cents ; qt., 55 cents.

Rustless Golden Wax. A strong grover, positively free from dust, and of remarkable vigor. The pods are meaty and well filled, of fine quality, and stringless from first to last. With its fine quality, hardiness, productiveness, and freedom from rust, it has become a general favorite and a great improvement over Golden Wax. Packet, io cents; $1 / 2$ pt., 20 cents; pt., 30 cents; qt., 55 cents.

Pencil-Pod Black Wax. Of recent introduction. Plants about fifteen inches high, when in bearing filled with long, round, handsome, golden yellow pods. Perfectly stringless, brittle, tender and mild in flavor when cooked. One of the best wax varieties.

Packet, 10 cents ; $1 / 2$ pint, 20 cents ; pint, 30 cents ; quart, 55 cents.

Golden Wax. Pods long, broad, flat, golden-ృellow, very fleshy and wax-like, stringless and brittle.

Packet, 10 cents; $1 / 2$ pt., 20 cents; pt., 30 cents ; qt., 55 cents.

Prolific German Black Wax. An old sort but still retaining its place in the front, and in quality being exceedingly tender and crisp. In our estimation it is one of the best. It is early and productive; long, yellow, round pods. Packet, 10 cents; $1 / 2$ pt., 20 cents ; pt..30 cents ; qt., 50 cents.

\section{"Sure-Crop" Stringless Wax. An absolutely} stringless, rist-proof wax-pod bush Bean. Pods seven to seven and a half inches long, about half an inch in diameter, and a oeautiful rich yellow color. Plant hardy, extremely prolific-in fact it bears more freely than any variety of recent introduction. Just the Bean for the family garden and on account of its size it will prove to he a ready seller on the market.

Packet, Io cents; $1 / 2$ pint 20 cents; pint, 35 cents ; quart, 65 cents.

Yosemite Mammoth Wax. The pods of this monster Wax Bean are often ten to fourteen inches in length, mearly all solid pulp, and absolutely stringless, cooking tender and delicious. The color of the pods is a rich golden jellow. The plants are extremely large, and should be planted twice as far apart as the ordinary Bush Beans.

Packet, 10 cents; $1 / 2$ pt.,25 cents; pt., 35 cents ; qt., 60 cents.

Refugee Wax. One of the very best of the wax-pod of long, round wax-like pods, perfectly stringless, tender and of the finest quality. In color, the pods are a rich. creamy white. This variety is classed among the early sorts, coming into bearing about 40 days after planting and continuing in bearing for several weeks. It is certainly one of the best Bealus for either the home garden or market.

Packet, ro cents ; 1/2 pt., 20 cents; pt. 30 cents; qt., 55 cents.

Michigan White Wax. A Bean of exceptional value on account of its earliness, vigorons growth and productiveness. The seed is clear white, and for cooking cannot be excelled. Will give unlimited satisfaction to those preferring a white Bean. May be cooked early in the pod, or used lat $r$ as dried Beans.

Packet, to cents; $1 / 2$ pt., 20 cents ; pt., 30 cents ; qt., 55 cents,

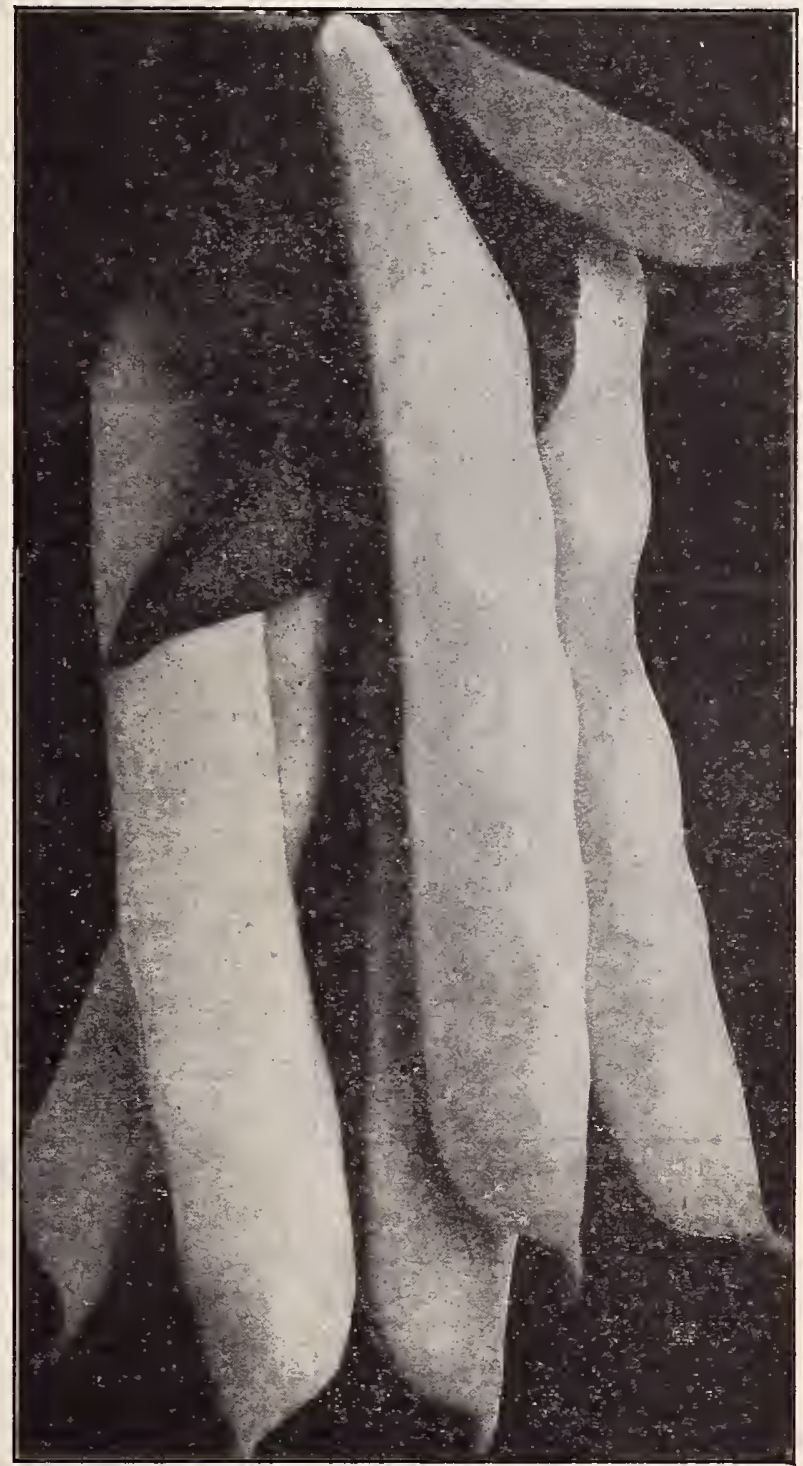

Fisher Stringless Golden Wax

A Bush Bean, with the immense Wax Pods of the Pole Bean; the highest quality; and pure white seed. The beautiful golden yellow pods are very tender, of the finest flavor and perfectly stringless. The plant is extraordinarily vigorous and productive, and free trom disease. The dry beans are pure white in color and of very superior quality for cooking. In season, it comes after other wax Beans are gone. This is one of the strong est features and will surely be appreciated by the market gardeners who grow for late market.

Packet, 15 cents ; one-half pint, 30 cents. 


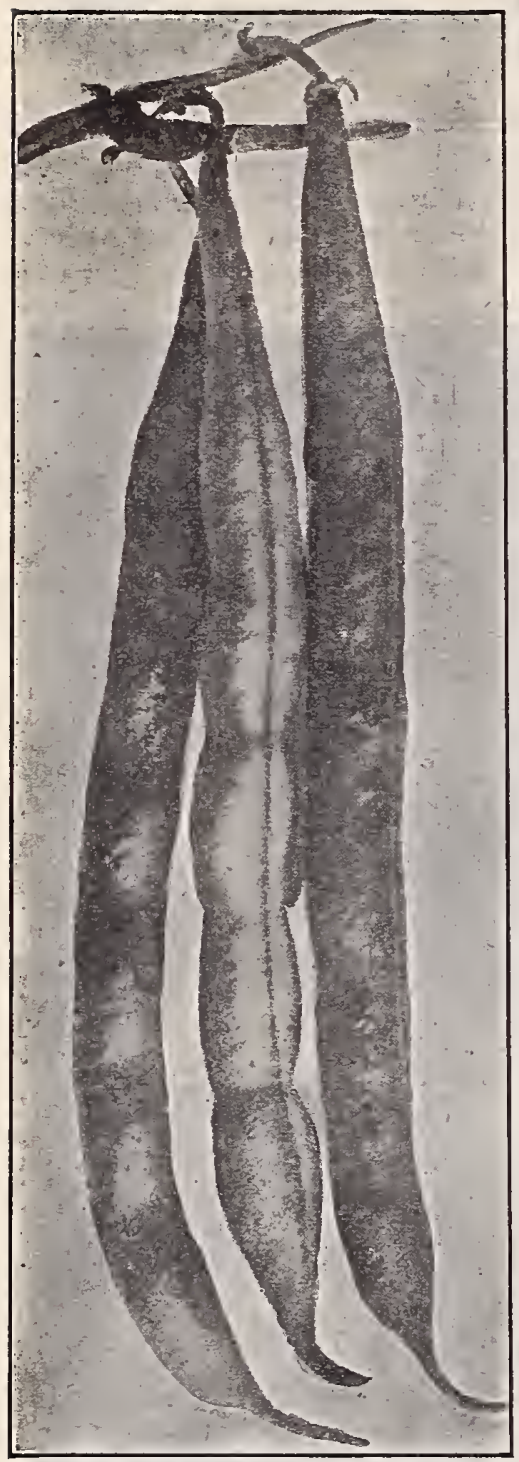

BRITTLE WAX BEAN (Page 7)

\section{FIELD BEANS}

Large White Marrow. Extensively grown as a dry bean for winter use. The beans are large, clear white, cooking dry and mealy. $1 / 2$ pt., 15 cts.; pt., $25 \mathrm{cts}$; qt., $40 \mathrm{cts}$.

Per bushel, at expense of purchaser, $\$ 4.50$

Red Kidney. A popular field sort. Hardy and heavy yielder. $1 / 2$ pt., $15 \mathrm{cts}$.; pt. $25 \mathrm{cts}$.; qt. $40 \mathrm{cts}$. Bushel, $\$ 4.50$. Freight or express to be paid by purchaser.

Unless otherwise stated, all the prices given in this Catalogue are postpaid. On page 9 we give prices on Beans when sent at the expense of the purchaser.

\section{Green Pod Bush Beans}

\section{Keeney's Stringless Refugee}

This grand NEW sort introduced by Mr. Keeney, the Bean expert, is without doubt the best green podded variety. After years of work and careful selection he has perfected a Hean having all the good points of the oldfashioned Refugee, differing only in tbe fact that it is perfectly stringless. It forms a strong, rank bush of many branches free from rust. Extremely: hardy. Pods are long, round as a pencil ; color light gray-green.

Packet, Io cents; crop failure ; packets only.

Stringless Green Pod. The pods are absolutely stringless, full, fleshy,-crisp, very tender, and of the finest flavor, remaining long in edible condition. Ready for the market two weeks earlier than Valentine, and very' prolific. 'Too much cannot be said in favor of this most excellent Bean, which has become a general favorite among growers. Packet, Io cents; $1 / 2$ pt., 20 cents; pt., 30 cents; qt., 50 cents.

Full Measure. A bush variety, popular on account of its wonderful yield and quality. Handsome long green, ronnd pods, of the highest quality and perfectly stringless. It also remains in picking condition many days after maturing, a strong point in its favor, either for market or home garden. Packet, $10 \mathrm{cts}$.; $1 / 2$ pt., $20 \mathrm{cts}$.; pt., $30 \mathrm{cts}$.; qt., $50 \mathrm{cts}$.

Giant Stringless Green-Pod. This is a distinct cross-bred variety, possessing all the merits of the old favorite Round-Pod Valentine, but is more prolific; the pods are large, being five to six inches in length, and are absolutely stringless, unusually crisp, round, full, and fleshy; qualities which highly recommend it for home and mark et garclens.

Packet, 10 cents ; $1 / 2$ pt., 20 cents ; pt., 30 cents ; qt., 50 cents.

Longfellow. A round, solid, very early, Green-Podded Bean. Good quality, being tender and crisp, also exceedingly prolific. One of the best for the home garden or market.

Packet, Io cents ; $1 / 2$ pt., 20 cents; pt., 30 cents ; qt., 50 cents.

Extra Early Red Valentine. One of the most popular of the extra early sorts. Pods roumd, fleshy, and well filled with beans of excellent quality. Pkt., 10 cents; $1 / 2$ pt., I5 cents; pt., 25 cents; qt., 45 cts.

Extra Early Refugee. One of the earliest of the green-podded surts, about two weeks earlier than the ordinary Refugee, while possessing all the superior qualities of that variety; straight, tencler pods, of fine flavor. Excellent for pickles. It is an enormous yielder.

Packet, Io cents ; $1 / 2$ pt. 20 cents ; pint, 30 cents ; qt., 50 cents.

\section{Bountiful.} into prominence in the past few years, owing to its superior quality, earliness and productiveness. One great feature is that while it bears early. its pods remain in an edible condition for a long time.

Packet, 10 cents; $1 / 2$ pt., 20 cents; pt., 30 cents; qt., 50 cents.

Dwarf Horticultural. A standard New. England sort. The pods are medium in length, cy-lindrical, curved, splashed with bright red on a g'ellowish ground. The beans are round and speckled.

Packet., 10 cents; $3 / 2$ pt., 20 cents; pt., $30 \mathrm{cts} ; \mathrm{qt}$., 50 cents.

Long Yellow Six Weeks. A very early standard variety, much prized for its productiveness and excellent quality. The green pods are oftent eight inches long, fender and brittle.

Packet, lo cents ; $1 / 2$ pint, 15 cents ; pint, 25 cents ; quart, 45 cents.

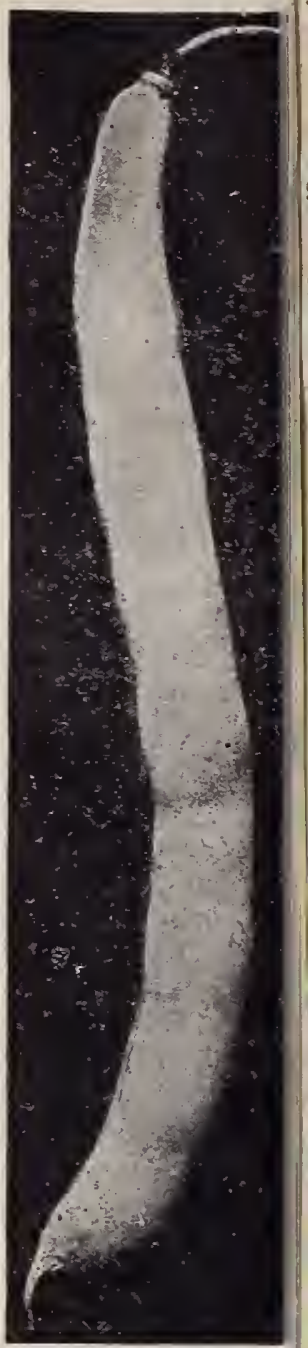

$\triangle E W$ SURE-CKUP

STRINGLESS WAX (Page 7)

\section{Pole, or Running Beans}

About the middle of May plant four to six beans around poles eight to ten feet high, setting poles four feet apart each way. Thin to three plants to a pole if the soil is rich.

Old Homestead (Kentucky Wonder). Earliest of the green Pole Beans and enormously pro. dictive. The pods though large, cook tender, and are delicious. A most excellent snap variety.

Packet, ro cents ; $1 / 2$ pint., 20 cents ; pint., 30 cents ; quart, 55 cents.

Early Golden Cluster Wax. Vigorous and very productive: pods enormously large and long, fl:at, waxy y'ellow, tender, and of excellent yuality.

Packet, Io cents ; $1 / 2$ pt., 20 cents ;pt., 30 cents; qt., 55 cents.

White Dutch Case-Knife. Good as a shell bean, either green or drv. One of the earliest and very productive. Packet, 1o cents; $1 / 2$ pt., 20 cents ; pt., 30 cents; qt., 55 cents.

London Horticultural, or Speckled Cranberry (Wren's Egg.) Vines moderately vigorous: pods short, broad, pale green, but becoming streaked with bright red. Popular as a shelled bean, either green or dry. Many people prefer it to the Limas.

Packet, Io cents ; $1 / 2$ pt., 20 cents ; pt., 30 cents; qt., 50 cents.

Scarlet Runner. An old favorite; used both as string and slielled beans. Vines strong, rapid growers, often used for ornamenting porches and trellises. Flowers brilliant scarlet. Blooms trom early in sum. mer until late in fall. Packet, 10 cents; $1 / 2$ pt., 20 cts.; pt., 30 cts.; qt., 55 cts. 


\section{LIMA BEANS}

POLE, or RUNNING

Siebert's Early Lima. An extra early Lima and extremely productive, remaining in bearing the whole season.

The beans are nearly as large as those of Large White Lima, and of the best quality.

Packet, ro cts.; 1/2 pt., 20 cents; pt., 30 cents ; qt., 55 cents.

Extra Early Jersey Lima. Does not differ materially from other varieties of Lima Beans, exicept in earliness in this it has the advantage of from ten days to two weeks over the Large White Lima.

Packet, Iocts; $1 / 2$ pint, 20 cts.; pt., 30 cents ; qt., 55 cents.

Improved Lima (Dreer's). Early and productive. Vines very stout and vigorous. The pods are much thicker than those of the other Limas and contain from four to five large, thick, white beans, of the very best quality. Packet, to cents; $1 / 2$ pt., 20 cents ; pt., 30 cents ; qt., 55 cents.

King of the Garden" Lima. A vigorous grower, requiring but two vines to each pole. Pegins flowering early, at the bottom of the pole, producing a contintous bloom and fruitage to the end of the season. Pods measure from five to eight inches, and contain five, six, and seven perfectly formed beans of superior edible quality. Packet, to cents ; 12 pt., 20 cents; pt., 30 cents ; qt., 55 cents.

Large White Lima. This old well -known sort needs 1 o description. The green beans most tender and delicious, are a delight to all in summer, and the dried beans in winter are excellent.

Packet, to cents ; $1 / 2$ pt., 20 cents ; pt., 30 cents ; qt., 55 cents.

\section{Dwarf Bush Lima Beans}

Fordhook Bush Lima. Without doubt the best Dwarf Bush Lima. Earlier than the Pole Limas by ten days. Pods measuring from four to five inches in length, containing four to five large beans. The plants grow to a height of 20 to 30 inches; are strong and bushy, of a rich dark green color.

Packet, I5 cents; $1 / 2$ pt. 25 cents; pt., 40 cents ; qt., 75 cents.

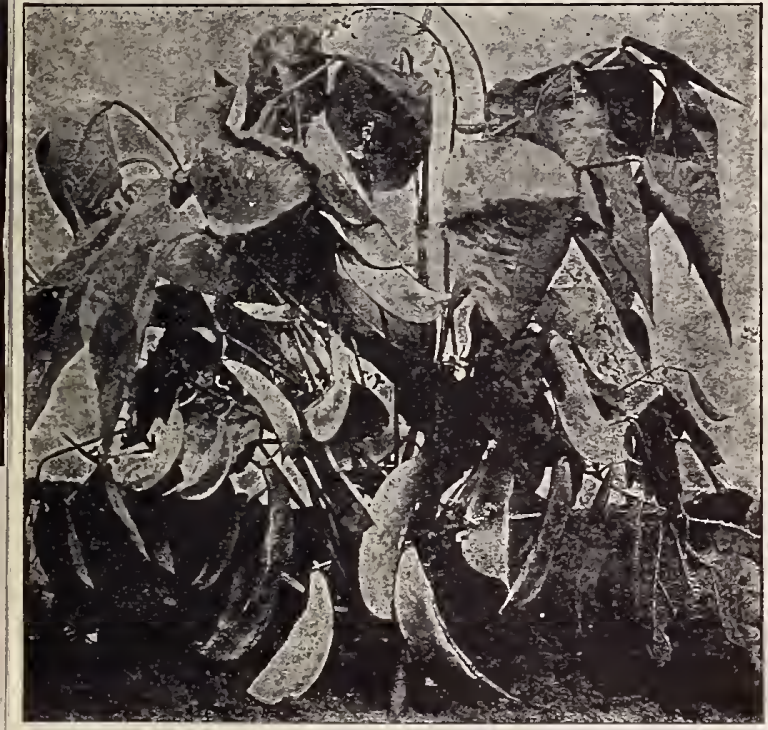

TRUE BUSH LIMA

True Bush Lima. (Burpee's.) The bush grows from eighteen to twenty-four inches high, branching freely, beariug from 50 to 200 large pods, well filled with delicious buttery beans. Plant in rows three feet apart, and thin to twelve or eighteen inches apart in the row. Packet, 10 cents : $1 / 2$ pt., 20 cents; pt., 35 cents; qt., 65 cents.

Wood's New Prolific Bush Lima. A greatly improved strain of Henderson's Bush Lima, or Dwarf Sieva Bean. Equally as early and prolific, and produces much larger pods and beans. About two weeks earlier than the true Limas; it is very desirable for planting for an early supply, or in latitudes where the true Limas do not succeed well.

Packet, 10 cents; $1 / 2$ pt., 20 cents ; pt., 30 cents : qt., 55 cents.

Improved Bush Lima Dreer's, Kumerle, or Thorburn.) Similar to above. The beans in the pod grow close together, are very thick, and of superior flavor. Packet, so cents; $1 / 2$ pt., 20 cents; pt.,: 30 cents; qt., 55 cents.

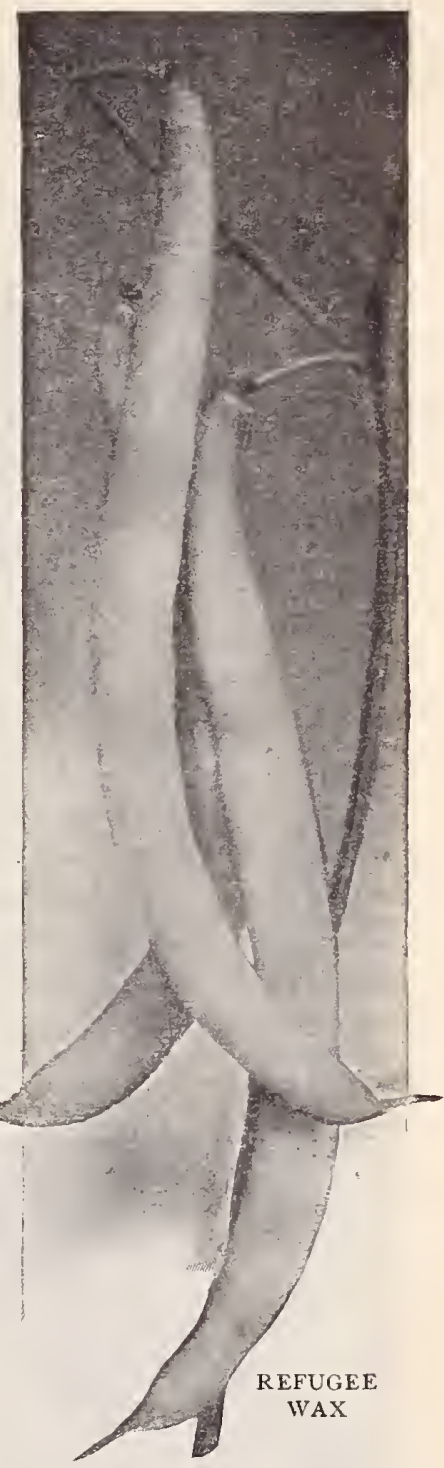

\section{Beans in Larger Quantities}

\section{By Express or Frieght, Not Prepaid}

In the following list we quote prices fo: Beans, when the express or freight charges are paid by the purchaser. No charge for bags, packing or cartage. On all seeds not includecl in this list, ordered to be shipped by express or freight not prepaid, the purchaser may derluct from the prices given in the preceding pages Io cents per pound in all seeds quoted by the pound.

Liountiful

Brittle Wax.

Extra Early Red Valentine

Extra Early Refugee.

Fordhook Bush Lima.

Full tleasure.

G i a n t Stringless Green-Pod Golden Wax, Rustless

Improved Bush Lima (Dreer's) London Horticultural.

\begin{tabular}{|c|c|c|c|}
\hline & $\$ 125$ & $\$ 225$ & Longfellow \\
\hline 35 & I 25 & $? 5$ & Long Yellow Six Weeks. \\
\hline $3^{\circ}$ & 110 &.$\infty$ & Michigan White Wax. \\
\hline $\begin{array}{l}35 \\
60\end{array}$ & $\begin{array}{ll}1 & 25 \\
2 & 25\end{array}$ & $\begin{array}{l}235 \\
400\end{array}$ & $\begin{array}{l}\text { Pencil Pod Black Wax } \\
\text { Prolific German Black Wax }\end{array}$ \\
\hline 35 & $x 25$ & 225 & Refugee Wax. \\
\hline 35 & 125 & 225 & Surecrop Stringless Wax \\
\hline $4^{\circ}$ & I 35 & 250 & Refingee 1000-1. \\
\hline $\begin{array}{l}40 \\
35\end{array}$ & $\begin{array}{l}135 \\
135\end{array}$ & $\begin{array}{ll}2 & 50 \\
2 & 25\end{array}$ & $\begin{array}{l}\text { Stringless Green Pod } \\
\text { True Bush Lima (Burpee;'s) }\end{array}$ \\
\hline
\end{tabular}

Wood's Prolific Bush Lima . Wardwell's Kidney Wax

Dreer's Improved Lima. Extra Early Jersey Lima. Early Golden Clinster Wax King of the Garden Lima. Large White Lima

Old Homestead.

Seibert's Large Early Lima
White Dutch Case Knife
Qt. 4 gts. Peck

$40 \quad 135 \quad 250$

$\begin{array}{lllll}40 & 1 & 35 & 2 & 50\end{array}$

$40 \quad 135 \quad 2 \quad 50$

$\begin{array}{lllll}40 & \text { I } & 35 & 2 & 50\end{array}$

40 I $35 \quad 250$

(Pole $4^{40} \quad 1 \quad 35 \quad 2 \quad 50$

$\begin{array}{lllll}40 & 1 & 35 & 2 & 50\end{array}$

$\begin{array}{lllll}40 & 1 & 35 & 2 & 50\end{array}$ 


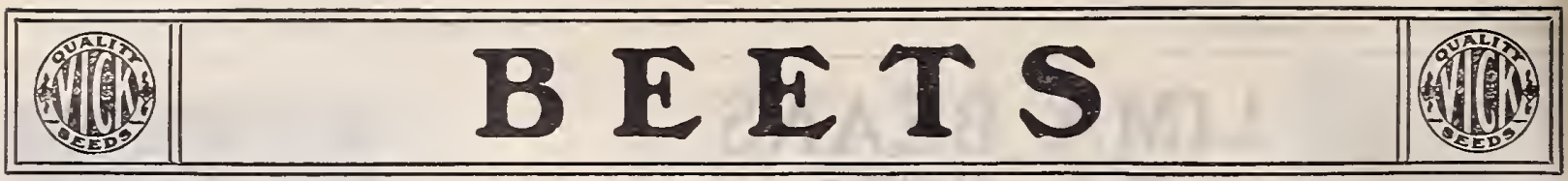

FOR Beets the soil should be rich, mellow, and deep. For early $F$ use, sow in a hotbed, and transplant, cutting off the outer leaves. For main crop, sow as early as the ground can be worked, in drills about one inch deep and the rows about fifteen or eighteen inches apart, dropping the seeds about two inches apart, and pressing the soil firmly over them. When the young plants are two to three inches high, thin to five or six inches. For winter use, the turnip rarieties may be sown the first week in June, and in October the roots can be stored in a cellar, corering them with sand to prevent shrireling; or they may be kept in pits out of doors. One ounce to fifty feet of drill; five pounds to an acre.

\section{Crosby's Eg'yptian. A Acareflly} strain of Egyptian, as early' as the original, but larger, thicker, smoother and of better quality. Flesh deep blood-red. It is a rapid grower, attaining a usable size quicker than any other variety, and does not become woody with age. Profitable in almost any soil and extremely satisfactory for the small gardener as well as for the market.

Packet, 5 cents; ounce, I5 cents; $1 / 4$ pound, 40 cents ; pound, $\$ 1.35$.

Extra Early Egyptian Blood Turnip. A standard sort; ten to twelve days earlier than the old Blood Turnip: fine for forcing and for first early crop out of doors. Roots rich, dark crimson, with very small tap roots: flesh dark blood-red, zoned with lighter shade: crisp, sweet and a desirable and profitable Beet for the market gardener, as well as an exceptionally good variety for the home garden.

Packet, 5 cents; ounce, 15 cents, $1 / 4$ pound, 40 cents ; pound, $\$ 1.25$.

Early Eclipse. This variety is exceedingly popular, and is one of the best early sorts. The tops are small, which admits of close planting. The roots are of a globular shape. Flesh fine-grained, very sweet, crisp, and tender: dark red, zoned with a lighter shade.

Packet, 5 cents; ounce, 15 cents ; $1 / 4$ pound, 40 cents ; pound, \$1.35.

Early Bassano. A good early turnip Beet, tender and juicy. Flesh white and rose. Grow's to a good size. Sown late, it keeps well in winter. Packet, 5 cents; ounce, 15 cents; $1 / 4$ pound, 40 cents; pound, \$I.25.

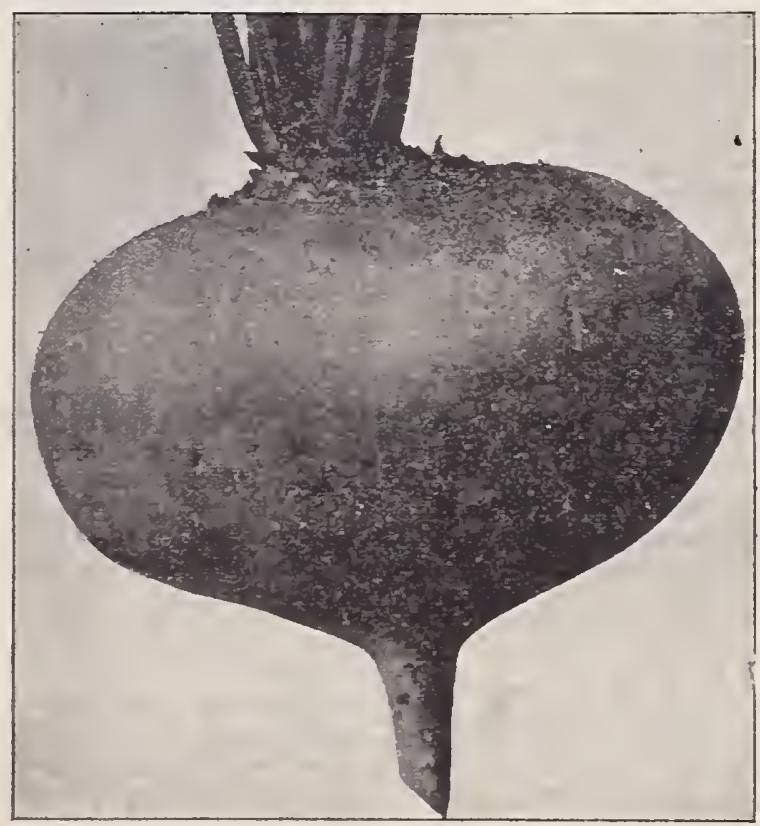

CRUSBY'S EGYPTIAN

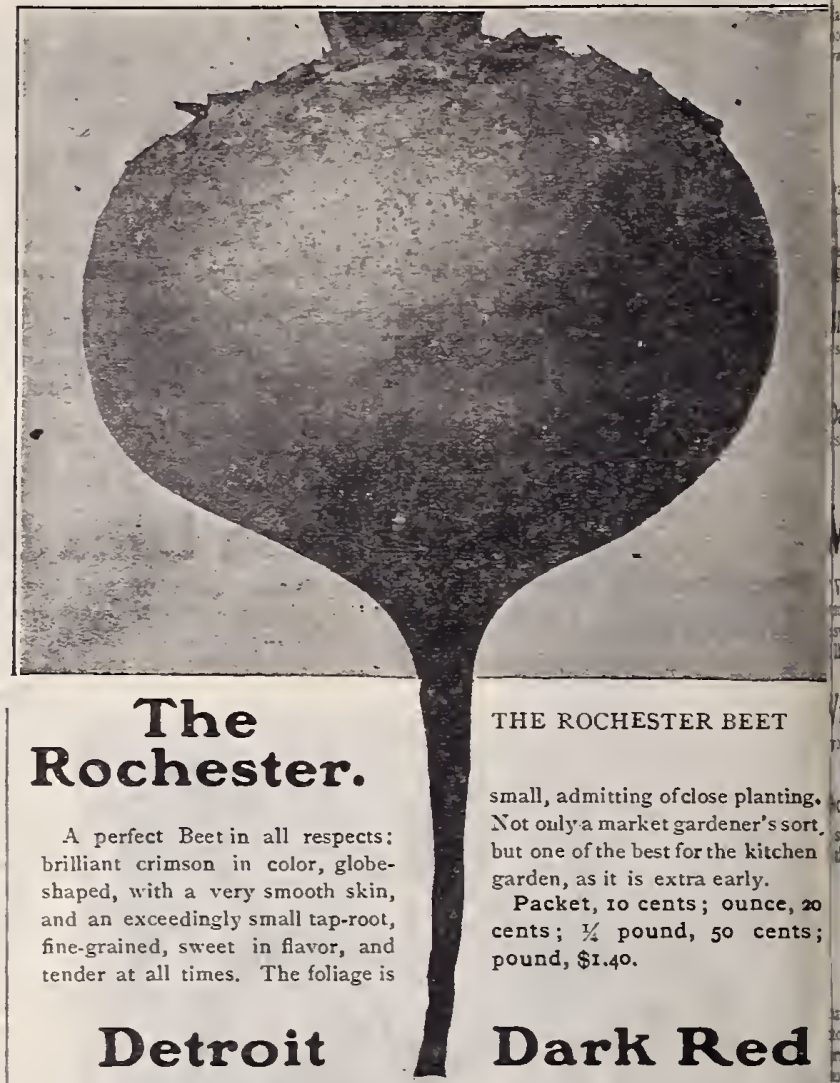

Roots medium in size, globular, and very smooth: skin a dark blood-red; flesh deep bright red, fine-grained, tender and sweet, remaining so long after many sorts become woody. Tops sniall, admitting of close planting. On account of its fine appearance it has been said to be particularly a market gardener's variety, but Detroit Dark Red is in every way a desirable Beet for bome gardening.

Packet. 5 cents; ounce, 15 cents ; $1 / 4$ pound, 40 cents; pound, $\$ 1.35$.

Edmand's Early Blood Turnip. A market gardener's strain regular in shape, round, with very small tap-root; flesh a deep blood-red, sweet and tender.

Packet, 5 cents; ounce, 15 cents; $1 / 4$ pound, 40 cents; pound, $\$ 1.35$.

Bastian's Early Blood Turnip. Tops small; roots turnip shaped; flesh tender, blood-red color. A good second early variety.

Packet, 5 cents ; ounce, 15 cents ; I/ pound, 40 cents ; pound, \$1.25.

Dewing's Improved Early Blood Turnip. Turnip-shaped, smooth, tender, and good. About ten days after Bassano.

Packet: 5 cents; ounce, 15 cents ; $1 / 4$ pound, 40 cents ; pound, $\$ 1.25$.

Half-Long Blood Red. An entirely distinct variety. The roots are symmetrical, somewhat pear-shaped, smooth and handsome: flesh a rich dark red, and very sweet, never becoming woody:

Packet, 5 cents ; ounce, 15 cents; $1 /$ pound, 40 cents ; pound, $\$ 1.25$.

Long Smooth Blood Red. Tops large, with good-sized long roots, tapering, and growing even with the surface; dark red; flesh very sweet and tender, remaining so when kept till spring. A popular winter sort. Packet, 5 cents; ounce, 15 cents; $1 / 4$ pound, 40 cents; pound. $\$ 1.25$. 


\section{MANGEL WURZEL For Stock Feeding}

Mangel Wurzels are of especial vaine to the stockman and dairyman. The roots are juicy, sweet and refreshing, act as a mild laxative, keep the cattle in good health, thus tending to produce flesh and to increase the fow of milk. The owner of even one or two cows should grow a sufficient quantity of Mangels to provide fresh food in winter when green food is unobtainable. For field culture the rows should be wide enough to admit the horse cultivator, and the roots not nearer than one foot in the row. Sow five or six pounds of seed to the acre.

\section{TWO NEW MANGELS}

Here are two improved varieties of Mangel, which have been worked up under the direction of the Danish Government. By careful selection they have secured Mlangels which yield a larger tonnage of sugar and other food material than was ever before known. Both of these stocks come from a grower who was granted a First Class Certificate by the Danish Government for the high percentage of sugar and solids in his stocks of these varieties. Sludstrup Barres is the variety to sow on light, deep soil, while Danish Tarroje surpasses all other varieties where the soil is shallow.

Sludstrup Barres. Long reddish yellow, grows well above ground, easy to pull. It is considered by the Danish growers to be the best Mangel in the world.

Ounce, to cents ; $1 / 4$ lb., 25 cents ; lb., 75 cents.

Danish Taaroje. Has all the good points of the Sludstrup. Barres, is. more dwarf, ovoid or oliveshaped, golden yellow. Grows more above the surface and is used extensively on heavy soil. Ounce, 10 cents; $1 / 4$ lb., 25 cents ; 1b., 75 cents.

\section{Vick's Golden Giant the Reliable Variety}

Very productive. Root of magnificent size, growing with half its bulk above ground, making it easy to lift and gather. Root uniform in shape, with a smooth, russet yellow skin; fiesh white, firm sweet, and greatly relished by cattle, An excellent keeper. Ounce, to cents: $1 / 41 \mathrm{~b} ., 20$ cents ; $1 b ., 60$ cents.

Vick's Mammoth Long Red This is truly a mammoth, a single root often productive, yielding, under favorable conditions, thirty to forty tons of roots per acre.

Ounce, 1o cents; $1 / 4 \mathrm{lb}$., 20 cents ; $1 \mathrm{~b}$., 60 cents.

Golden Tankard. A distinct variety, particularly valuable on account of its richness in saccharine matter, and highly prized by dairymen for its milk-producing qualities. All stock will thrive on it. Deep yellow fiesh and skin. Ounce, 10 cents; $1 / 41 \mathrm{~b}$., 20 cents; $1 \mathrm{~b}$., 60 cents.

\section{SUGAR BEETS}

When planted for a sugar crop, from six to eight pounds of seed will be required for an acre. Seed may be sown in drills twenty to thirty inches apart. When beets are up two or three inches high, they should be thinned out so as to stand from six to eight inches apart. Discontinue cultivation after formation of roots has commenced. The large amount of sugar contained in the Sugar Beet makes it much relished by stock, and desirable for fattening.

Klein Wanzlęben Sugar. Is being cultivated in Germany almost exclusively for sugar, on account of its great yield of saccharine matter. It gives good returns in any_ordinary soil. Ounce, ro cents ; $3 / 4$ lb., 25 cents ; lb., 75 cents.

Imperial White Sugar. One of the sweetest and best of Sugar Beets, Very productive and desirable for stock of all kinds. Ounce, ro cents; $1 / 41 \mathrm{~b},{ }_{2} 5$ cents; $1 b ., 75$ cents.

Vilmorin's Red-Top Sugar. Matures earlier than other varieties of Sugar Beet, and yields a good percentage of sigar. A heavy cropper, largely grown for cattle feeding.

Ounce, to cents; $1 / 4$ lb., 20 cents; 16.60 cents.

\section{FOLIAGE BEETS-Swiss Chard}

\section{Used for Leaves and Leaf-Stalks Only}

The Swiss Chard is cultivated exclusively for the leaves, which may be cooked like Spinach. Seed may be sown in April or May, in drills eighteen inches apart and an inch and a half deep. Thin the plants to ten or twelve inches apart and cultivate the same as for the common Red Beet.

Beck's Improved Sea Kale. A variety of Beet with tender leaves, popular for . cooking as "greens;" if sown at the same time uch earlier. The large leaves may be cut from time to time all summer. The middle of the leaf is cooked and served like Asparagus; the other portions used like Spinach. Packet, 5 cents ; oz., 1o cents; $1 / 4 \mathrm{lb}$., 25 cents; $1 \mathrm{~b} ., 80$ cents.

Large-Ribbed Scarlet Brazilian. Stems and veins a beantiful crimson color; fine for garnishing. Packet, 5 cents; oz., to cents ; $1 / 4$ ib., 25 cents; lb., 75 cents.

Large-Ribbed Yellow Brazilian. Same as above, except in color, which is golden yellow. Packet, 5 cents ; oz., 10 cents ; $1 / 4$ 1b., 25 cents; 1 b., 75 cents.

Large-Ribbed Silver. Packet, 5 cents ; oz., ro cents ; $1 / 4$ lb., 25 cents; $1 b ., 75$ cents.

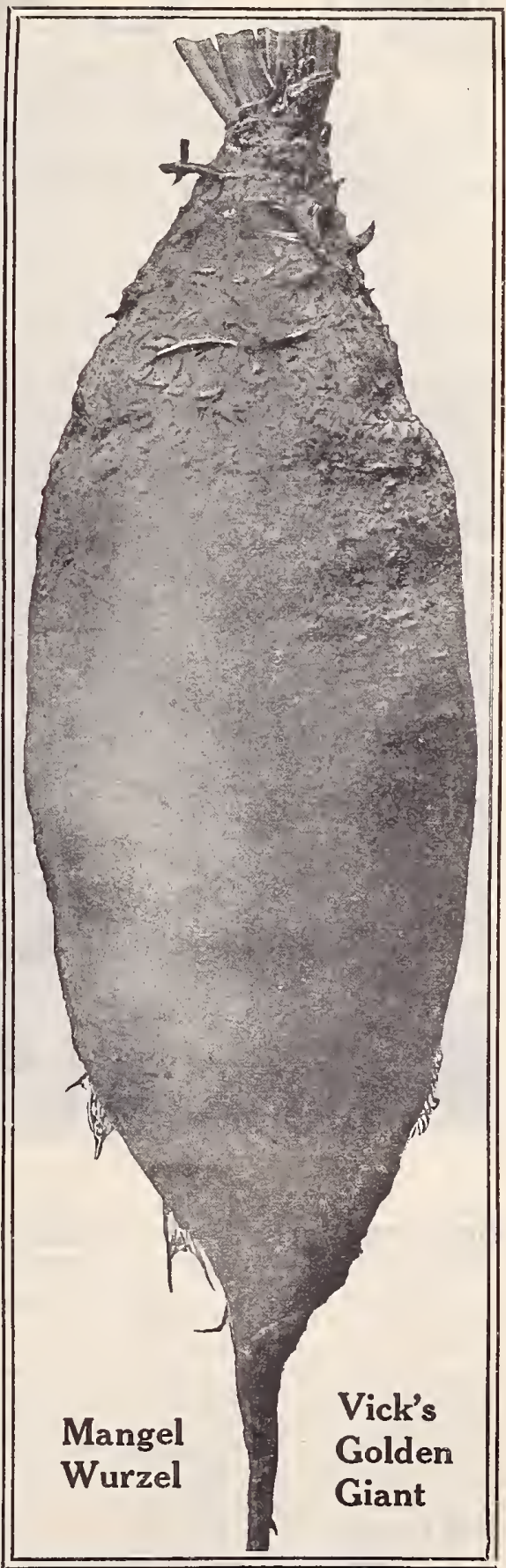

We pay the postage or express charges on all goods listed in this catalogue, unless otherwise noted. It is just as easy to order of us as if you lived next door. 


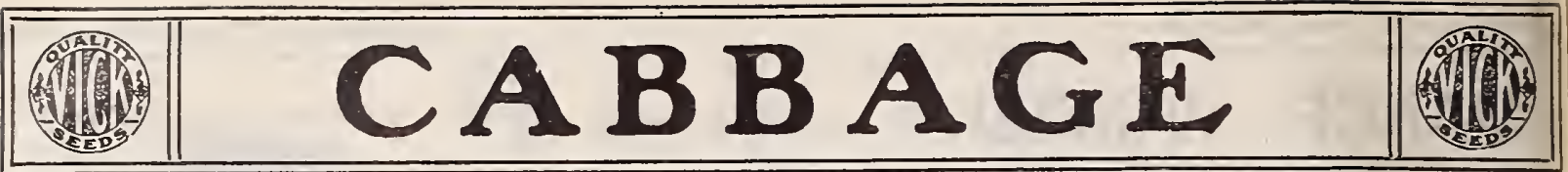

E ARLY Cabbage is a most important crop for the gardener and trucker, while each year late varieties become more valuable to the

E man who has a small farm. Realizing the importance of providing only the best varieties, we have given special attention to our stock of Cabbage seed, and we know that no varieties listed by any seed firm are more dependable in every way than ours. Plant the Inrge varieties three feet apart; the small, early sorts, eighteen inches to two feet, setting the plants clown to the first leaf. About four ounces of seed to one acre. If calsbages are troubled by insects, use Vick's Insect Exterminator - see page 101.

To those growing for market we shall be pleased to quote special prices on large lots.

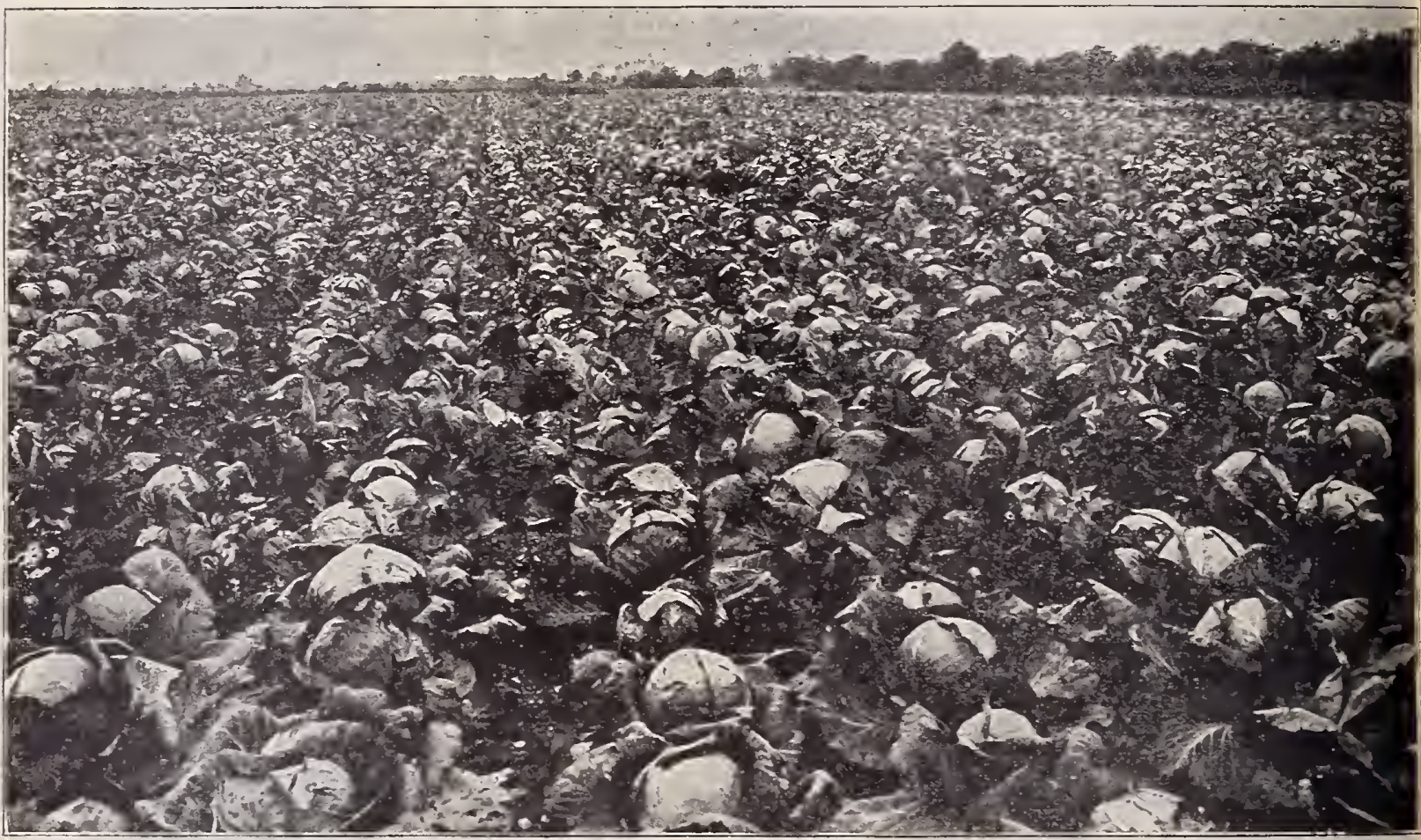

FIELD OF COPENHAGEN MARKET

\section{Selected Early Jersey Wakefield. The headsare}

Packet, 5 cents; oz., 25 cents; $1 / 4$ lb., 75 cents; $1 b ., \$ 2.50$

Charleston, or Large Wakefield. A strain of Wakefield in wicl Packet, 5 cents; oz., 25 cents; $1 /$ lb., 75 cents; Ib., \$2.50.

Early Winnigstadt. A distinct second early sort, and an old favorite

niform in size, sharply conical in shape, and very solid $i t$ is raluable makes a good winter Cabbage.

Packet, 5 cents; oz., 20 cents $1 / 4$ lb., 60 cents ; ib., $\$ 2 . \infty$.

20th Century.

duge, and is without exception the carliest round hcad Cabbage yet intro-
duced. The heads are round mediun sized, and solid as a cannoul ball.

Packet, ro cents: oz., 40 cents; I/4 Ib., \$1.10; Ib. \$3.50.

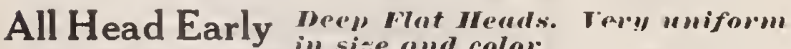
The earliest of all extra large Cithbages. The leaves are compact, so will Packet, 5 cents ; oz., 20 cents ; $1 / 416 ., 60$ cents; 1b., $\$ 2 . \infty$.

\section{COPENHAGEN MARKET}

\section{THE BEST OF ALL EARLY CABBAGE}

Stands Longer Without Bursting Than Other Early Sorts

It is with pleasure and confilence that we offer this new early Calbbage, knowing it will give perfect satisfaction wherever grown, both as to quality and yield. Everyone faniliar with the-Cabbage knows the old and propular Danish Ballhead, the best of all the late Cabbages. This new extra early variety, ripening with Charleston Waleefield, also originated in Denmark, and is as good, in its class, as the old farorite Danish Ballhead. The stem is short, the head round and solid. When ready for cutting, Copenhagen Market is the heariest of the extra early varieties, and if left until fully mature, frequently weighs eight to ten pounds. The leaves are small, compact and close to the head so it will stand close planting. The inside is fine grained, tencler, pure white and compact. Fither for the home garden or market it is bound to become a leader.

Packet, ro cents; ' 0 ., I5 cents; ounce; 50 cents ; If $1 \mathrm{~b} ., \$ 1.40 ; 1 \mathrm{~b} ., \$ 5.00$. 


\section{Volga.}

We cousider this the most profitaole Cabbage we have ever grown for a fall crop. The heads are extremely solid, large, round as a ball, of uniform size, and do not crack: few outer leaves and a short stem. Not only have we tested it on our tria farm, and found it in all respects an exponent of Vick Quality, but multitudes of growers proclaim its superiority. Packet, ro cents; oz., 40 cents; $1 / 4$ 1b., \$1.10; 1b., \$3.50.

Improved Early Summer. It is a large-heading, second early variety, nearly round, somewhat flattened, solid and uniform in size, and will keep longer withuut bursting than most of the early sorts. Packet, 5 cents ; oz., 20 cents ; $1 / 2$ lb., 60 cents ; 1 b., $\$ 2.00$.

A 11 Seasons A very superior, sure-heading, long-keeping are large, nearly round, somewhat flattened, very solid, and in quality the best. Packet, 5 cents; oz., 25 cents ; $1 / 4$ lb., 75 cents; 1 b., $\$ 2.50$.

Autumn IKing or World Beater. Grows to an enormous size, making heads as solid as a rock, and coming unifurmly true to type. It can be relied upon to produce a greater weight of crop from the sime space of ground than most of the late sorts, having fow outer leaves.

Packet, 5 cents; oz., 20 cents ; $1 / 4$ lb., 60 cents ; 1 b., $\$ 2 . \infty$.

Louisville Drumhead. A variety grown largely by market gardeners in the Southwest. It stands hot weather better than most sorts, and is a sure cropper. Packet, 5 cents ; oz., 30 cents ; $1 / 4$ lb., 85 cents ; lb., $\$ 3.00$.

Ther. A selection from the Danish Ballhead. The the ty.pe to a lirger and flatter liead and shbrter stem. It is preferred by some on account of its size. Packet, 5 cents; $1 / 4$ oz., ro cents oz., 30 cents; $1 / 41$ lb., 85 cents; lb., $\$ 3.00$.

\section{Selected Premium Late Flat Dutch.} An old, reliable, and popular" Cabbage. It produces large; soiid heads of stuperior quality, keeping in hest condition for a long time.

Packet, 5 cents; oz., 30 cents ; 1/4 lb., 85 cents; lb. $\$ 3.00$.

Improved American Savoy. The Savoy Cabbages deserve to be better known in America. They are superior to other Calsbages for cooking, having greater tenderness and delicacy of flavor Improved American Savoy is the best of all either for market or kitchen garden, and a reliable header. The heads are large, solid, and possess a fine clelicate flavor The curled and crimped leaves are of a dark rich green color. Packet, 5 cents; oz., 20 cents; $1 / 41 \mathrm{lb} ., 60$ cents; Ib., $\$ 2.00$.

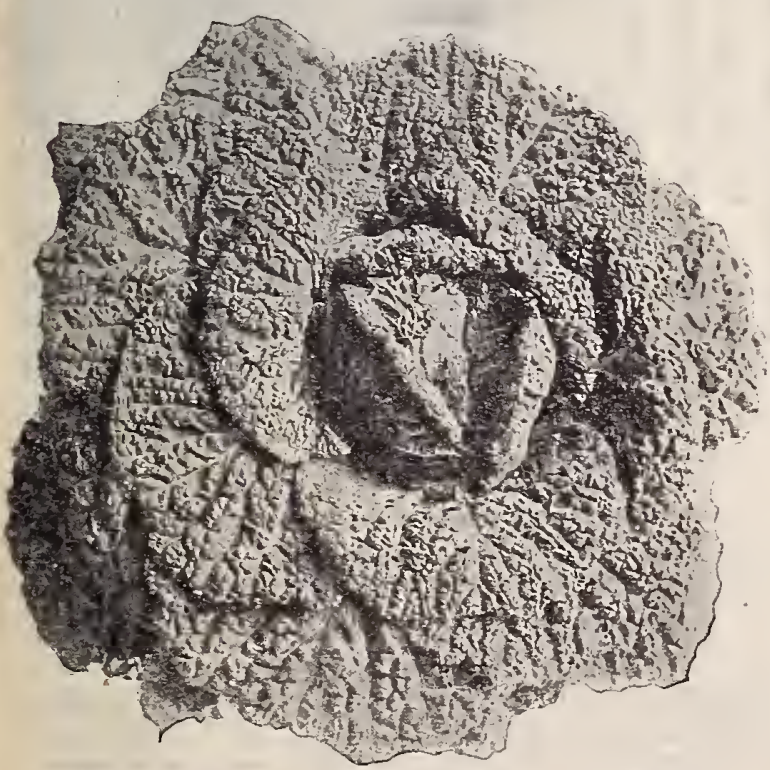

CABBAGE, IMPROVED AMERICAN SAVOY

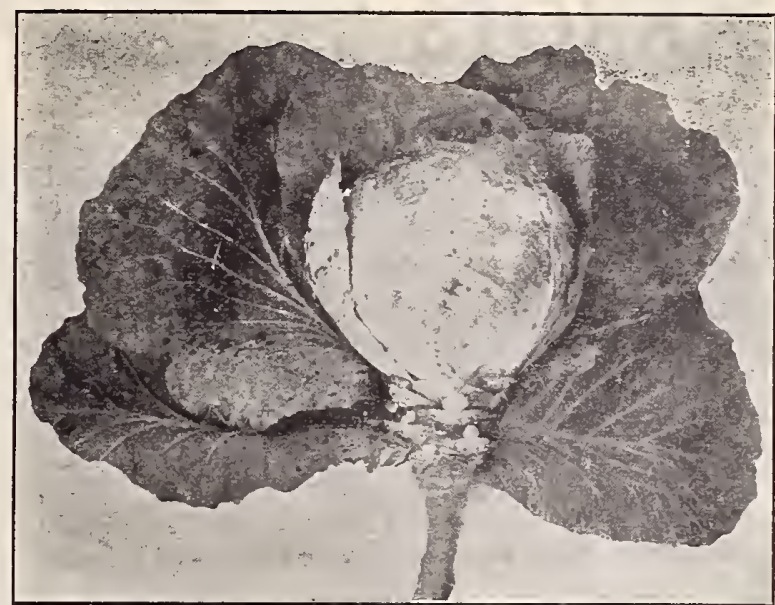

IMPROVED DANISH BALLHEAD

\section{Vick's Improved Danish

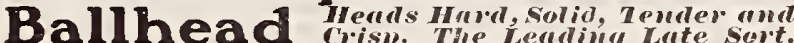

\section{No Cabbage of late introduction has attined such great popularity, or given}

such general satisfaction as V'ick's Improved Danish Ballhead. It commands a higher price in the market than any other variety. It is reheads are of medium size, with few outer leaves, admitting of close planting; exceedingly fine-grained, hardiest of all, tender, crisp, solid, with no waste Danish Balihead Cabbage, and this we import dircct from our original grower in Denmark. Packet, 5 cents; $1 / 40 z$., Io cents; oz., 30 cents ; $1 / 4$ lb., 85 cents ; 1b., \$3.00.

\section{Vick's Short-Stemmed Early Danish Ballhead. A choice strain selected from}

Cahbage, that has become one of the best and most popular sorts both for homeand market growing. The heads are very large: as round as balls and as solid as bullets. It is short-stemmed and as strong and vigorous as as well as Danish Ballhead. Packet, 5 cents; $1 / 40 z$, 10 cents; oz., 30 cents ; 1/4 lb., 85 cents ; lb., \$3.00.

The Danish Ballheads are particularly adapted to the Northern States, and do not reach perfection in the warmer southern climates.

Mammoth Rock Red. This is a fine red Cabbage and a most reliable header. The quality is excellent. The head is extra large, round, very solid, 1b., $\$ 2,00$

Stonehead (Round Red) A new variety of of good qualities. Hard almost as a rock. Rich dark red, large round heads, measuring eight inches in diameter, uniform in size. Fine quality, keeps well through the winter. Short-stemmed and compact in growth. The growers of Denmark have introduced a number of splendid varieties in the past few years. The The Stonehead is one of the best. Packet, ro cents; $1 / 4 \mathrm{oz}$, 20 cents; ounce, 50 cents, I $41 \mathrm{~b}, \$ 1.50$; pound, $\$ 5.00$

OTHER STANDARD VARIETIES OF CABBAGE. Early Blood Red. Early Spring Fottler's Improved Brunswick.

Surehead Improved Succession Large Late Drumhead. Packet, 5 cents ; ounce, 20 cents ; $1 / 4$ lb., 75 cents; pound, $\$ 2.00$.

\section{COLLARDS}

This is a variety of Cabbage largely grown in the South, where it is extensisely used for both table and stock. It forms a large, loose, open head or mass of leaves. Freezing does not injure it. Sow steds in the South from January to May, and August to September.

True Georgia, Packet, 5 çents; oz., Io cents; 1 b., $\$ 1 . \infty$, 


\section{CARROTS For the Home and CARROTS Market Garden}

GOR garden culture, sow in drills sixteen to eighteen inches apart, 1 covering the seed half an inch to an inch deep. For field culture, sow in drills from twenty to thirty inches apart, and when plants are one to two inclies high thin out from three to eight inches apart in the rows, according to the variety. One ounce will sow 100 feet of drill; three to four pounds to an acre.

Earliest French Forcing. The earliest of all varieties, and especially adapted for cultivation under glass, both on account of its earliness and the shortness and small size of its roots. It is also one of the best sorts for the table: delicate, fine grained, and remarkably fine flavored. It is also used by gardeners for bunching for early market. Root orange-red. Top very small. Packet, 5 cents; ounce, 20 cents; $1 / 4$ pound, 65 cents; pound, $\$ 2.25$.

Early Scarlet Horn. This is a favorite for early crop, but not large; sold extensively in all markets bunched. The tops-are small; roots topshaped, stump-rooted, therefore easily pulled. Grows well in shallow soil.

Packet, 5 cents ; ounce, 20 cents ; $1 / 4$ pound, 65 cents ; pound, $\$ 2,15$.

Half-Iong Nantes Stump-rooted. Of medium size admirably adapted for bunching, and one of the best for summer use in the home garden. Roots about six inches long, very smooth and cylindrica!. with no core; trery sweet and tender.

Packet, 5 cents ; ounce, 25 cents ; $1 / 4$ pound, 60 cents ; pound, $\$ 2.00$.

Chantenay Stump-rooted. One of the best early Carrots in cultivation. In shape it is midway between the Half-Long Nantes Stump-Rooted and the Guerande or Oxheart varieties, nearly equaling the former in length, and having the broad shoulder and tapering root of the latter. Its color is orange-red: the flesh crisp and tender. Early and a heavy cropper. A Carrct which market gardeners should plant for main crop. Packet, 5 cents ; ounce, 20 cents ; $1 / 4$ pound, 55 cents; pound, $\$ 1.90$.

Guerande or Oxheart. This variety has given great satisfaction. While not attaining one-half the length of many other varieties, it will compare favorably in bulk of crop, as on good land it will produce Carrots four to six inches in diameter. The crop can be pulled by hand. Excellent for table use, as well as for stock. Roots are about six inches long, smooth and cylindrical; no core; sweet and tender.

Packet, 5 cents ; ounce, 20 cents ; 1//4 pound, 55 cents ; pound, \$1.90.

Danvers Ialf-Long Orange. A first-class variety: flesh dark orange. The smooth, handsome roots are of medium length, tapering uniformly to a blunt point ; flesh sweet, crisp and tender. A gredt favorite with market gardeners; also va!uable for a field crop.

Packet, 5 cents ; ounce, 20 cents; T/4 pound. 55 cents; pound, $\$ I .90$.

St. Valery Intermediate. One of the best and handsomest màin-crop Carrots. The roots are symmetrical, tapering regularly from the shoulder to tip, smooth, and free from side roots. Enormously productive. Very desirable for private gardens, as well as for market.

Packet, 5 cents ; ounce, 20 cents ; I/ pound, 55 cents ; pound, \$r.9o.

Improved Long Orange. It grows to a large size, some specimens measuring twelve iuches in length. Enormous crops can te grown under fair culture. One of the best varieties for feeding stock.

Packet, 5 cents ; ounce, 15 cents; $1 / 4$ pound, 50 cents; pound. $\$ 1.75$

Improved Short White (Vosges). For a field Carrot this is unexcelled. The roots are short, very heavy at the shoulder, tapering to a point, and therefore easily harvested. Especially suited to shallow soils.

Packet, 5 cents ; ounce, 20 cents ; $1 / 4$ pound, 60 cents; pound, $\$ 2.00$.

Belgian Carrots. The great stock-feeding Carrots of Europe. Grow to a large size. Very productive. Orange Belgian, White Belgian.

Packet, 5 cents ; ounce, 15 cents ; $1 / 4$ pound, 45 cents ; pound, \$r. 50.

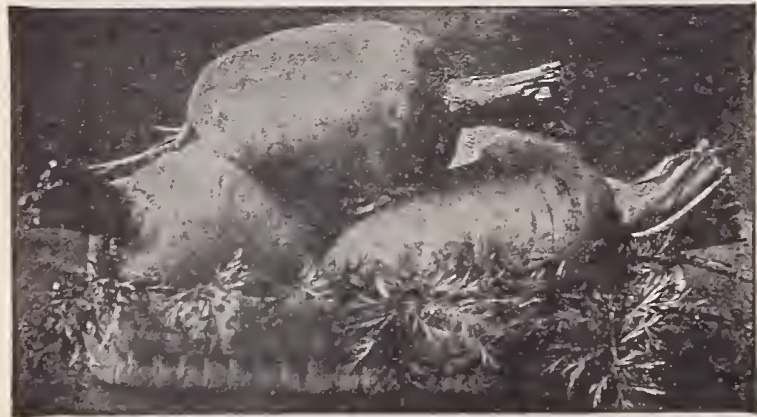

CARROT, GUERANDE OR OXHEARI
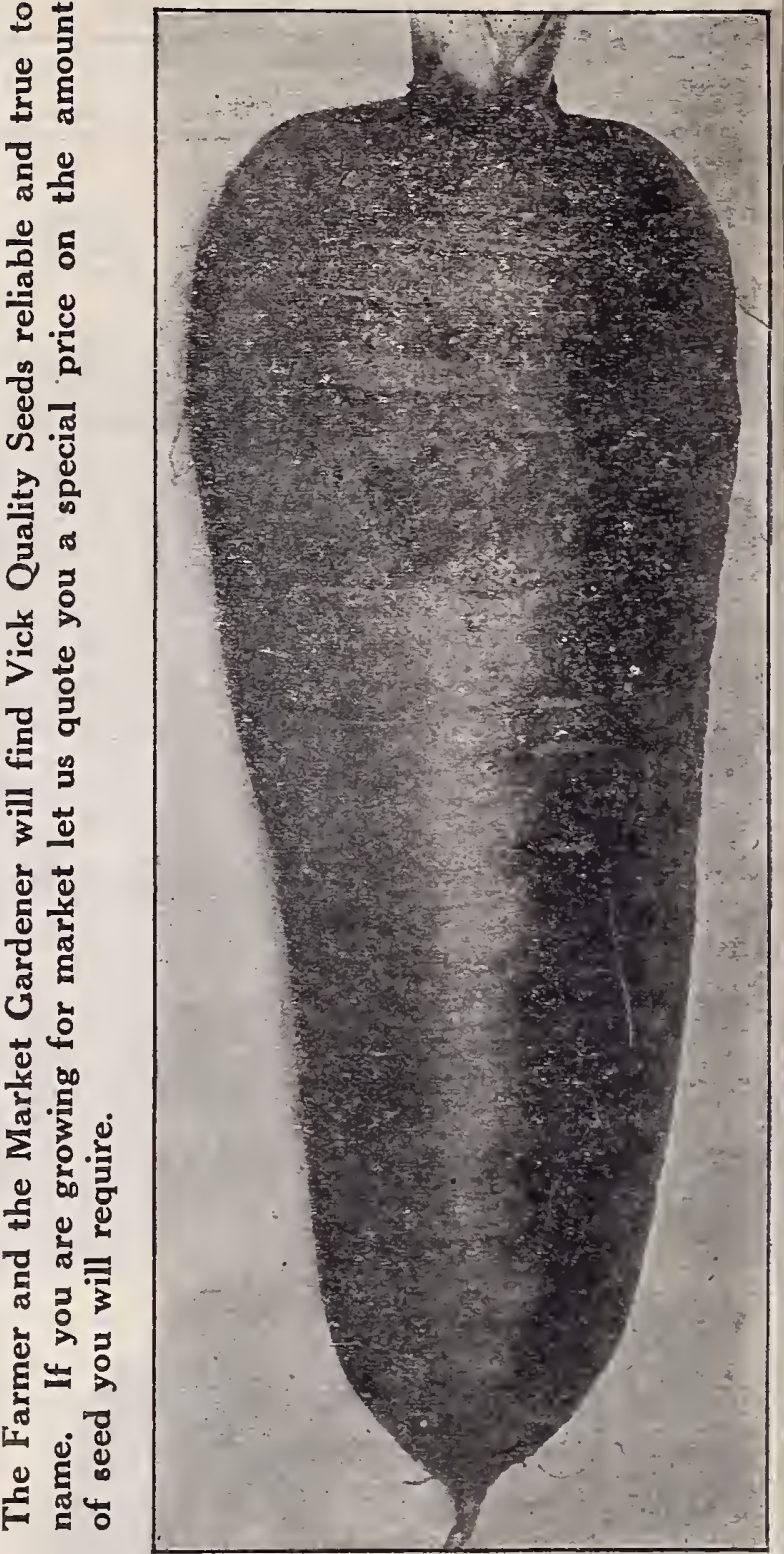

CARRO'J', CHANTENAY STUMP-ROOTED Illustration Natural Size

\section{CIVES OR CHIVES}

These are very hardy perennial plants, belonging to the Onion family. They are grown exclusively for their tops, which are used for giving a mild onion-like Havor to soups, stews, etc. Planted in clumps in any good garden soil, they grow readily, and increase so as to render a division necessary. The tops appear, very early in spring, and can be cut throughout the season.

\section{Roots, per bunch, 25 cents, by mail, prepaid.}

\section{CORN SALAD, Fetticus}

A favorite salad plint in Europe, used in winter and spring as a substitute for Lettuce. The leaves are sometimes boiled and served as Spinach. It is hardy and quick-growing. Sown in August and September, in drills one foot part, and protected with a few leaves or straw during winter, it can be gathered very early in spring. Sown in April it is soon fit for use. The soil for Corn Salad should be very rich. Sow two ousces to 100 feet of drill. Packet, 5 cents; 0z., so cents; lb., 60 cents. 

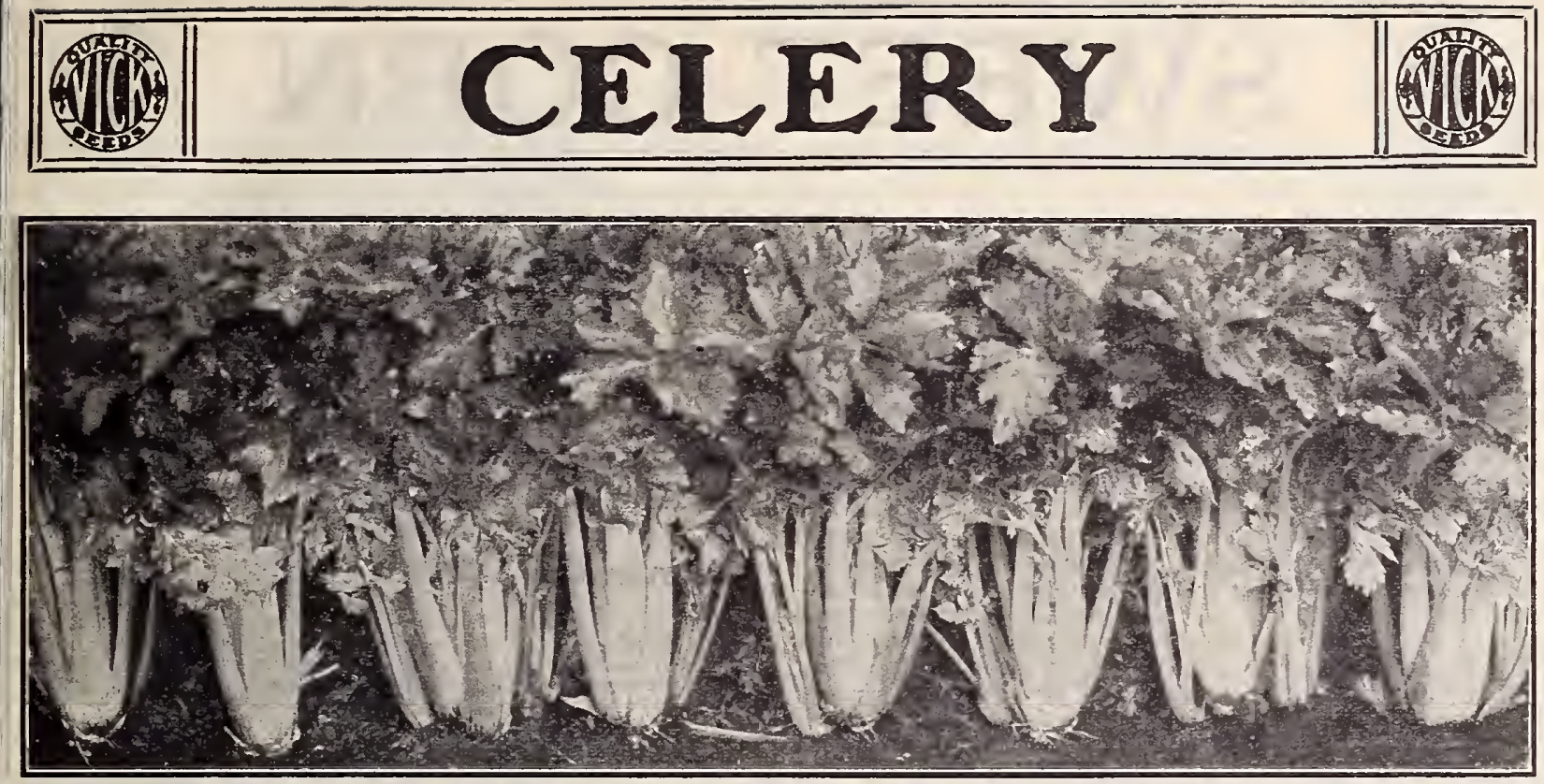

CELERY, PARIS GOLDEN DWARF SELF-BLANCHING

\section{If you are growing for market write for}

\begin{abstract}
Celery seed is slow to germinate, and when early plants are wanted it should be sown in a hotbed in February or March, barely covering the seed. When the flant: are large enough, transplant into coldframes, one and one half inches apart; water and attend carefully ; keep the temperature moderate; and when the weather is suitable, from middle of May till June, transplant into the open ground. For main crop or home garden, sow in shallow drills in the open ground, as soon as the soil can be worked. Rolling or pressing in the seed will give more satisfactory results than merely covering it. See that the bed is kept well watered. When the plants are two inches high, thin out to three inches apart in the rows; and when four inches high, cut off the tops to make the plants stocky. The best time to plant is that which will bring the plants to maturity during the cool, moist weather - in this locality from the middle of June to early in July. Never hoe or earth up in moist weather, nor when the plants are wet with dew, as it would cause serious injury. One ounce of seed will produce 4,000 to 5,000 plants.
\end{abstract}

\section{Paris Golden Dwarf Self- Blanching}

No Celery offered to the American people approaches this variety in quality, flavor, color or habit of growth.

Paris Golden Dwarf Self-Blanching forms a solid stalk, tender and crisp; the delicate cream-yellow color makes it attractive when offered for sale as well as inviting when on the table. The flavor is of the best-rich and nutty. In habit of growth it is dwarf, stocky, uniform in height, and very compact. This variety originated in France and our seed is grown by the originator, who ships it directly to us; it is the best that money will buy.

Our special gardener's strain, packet, 20 cents ;

$$
1 / 2 \text { oz., } \$ 1.25 ; \text { oz., } \$ 2.00 \text {. }
$$

Rose-Ribbed Paris Self-Blanching. This magnificent sort comes to us from the originator, the grower of our market garden strain of Golden Self-Blanching, and resembles in general character that most valuable variety. The stalks are large, thick, and beautiful, tinted with rose color at the base, while the upper part of the stems, particularly the hearts, are a deep, rich yellow.

Packet, 5 cents; one-half oz., Is cents ; oz., 25 cents.

\section{special prices on any seeds you may need.}

Pink Plume. The red Celeries are of very fine quality, possessing a peculiarly rich nutty flavor. This variety possesses all these good qualities, while its delicate pink color gives it a handsome appearance. Packet, 5 cts., one-half oz., I5 cents., oz., 25 cts.

White Plume. A variety especially adapted to cultivation by amateurs as its inner stalks and leaves are naturally white, and do not require blanching by the old process of high banking. Bytying up the stalks and drawing up the soil with the hoe, the work of blanching is complete. Tender, crisp, and of gnod flavor.

Packet, to cents; half oz., 30 cents.; oz., 50 cents.

Giant Pascal. This is a selection from the Golden Self-Blanching Celery. The stalks are very large, thick, solid, and crisp. It has a fine nutty flavor, and is free from any trace of bitterness. It blanches with but slight earthing up and retains its fieshness a long time after being marketed. Packet, ro cents; half oz., 20 cents ; oz., 35 cents.

Improved Golden Heart. A from the old favorite Golden Heart Celery. Grown extensively for private use as well as for market. Improved Golden Heart is one of the finest late varieties. The heart, when blanched is a rich golden yellow:

Paçket, 5 cents ; half oz., I5 cents; oz., 25 cents; $1 \mathrm{~b}$., $\$ 2.25$.

Winter Queen. A splendid new variety, having the long keepeasily, like the Golden Self Blanching. Hardy, vignrous and of fine quality. The stalks are rounder than those of Golden Self-Blanching and the heart vary large, creamy white, brittle and delicious.

Packet, ro cents; half oz., I5 cents; $0 z ., 25$ cents.

Turnip-Rooted (Celeriac) Large Smooth Prague. An morod form of the Turnip-rooted Celery. Roots smooth, and free from side roots; a profitable variety for market gardeners. Sow seed same as Celery, transplant into rows two feet apart and about six to eight inches in the row. No earthirg up is required for Celeriac, as it is the roots which are the edible portion of the vegetable. Packet, 5 cents; half oz., 20 cents; $0 z ., 35$ cents.

Celery Seed for flavoring. Excellent. Ounce, to cents; lb., 40 cents 


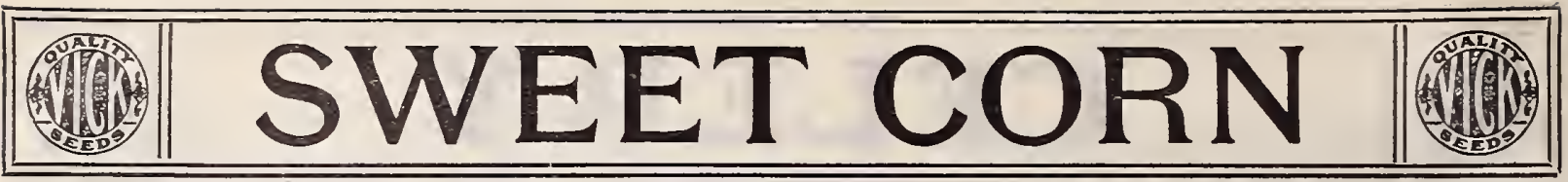

CWEET CORN should not be planted very early in the season, for it will not make any progress until the weather is warm, and the $\checkmark$ seed will be very apt to rot. Plant in hills, three feet apart for the earlier varieties, and three and one half to fourfeet for tlie late ones. One quart will plant 200 hills; 8 to 10 quarts for an acre in hills. For a succession use Cory, Vick's Golden Nugget, Stowell's Evergreen and Country Gentleman.

\section{Vick's Golden Nugget}

The most popular Sweet Corn we have ever sold

Ripens only a few days after the White Cory

Vick's Golden Nugget was introduced in 1892 and was received with great enthusiam by our customers. During all these years it has been grown side by side with many other varieties and in every case it has widened its circle of friends. Its great productiveness is one of its strongest features. It invariably produces from two to four ears to a stalk. The ears are large, from one and a lialf to two inches in diameter, and fully seven inches long. There are twelve rows of plump, tender, sweet and milky kernels. It is particularly attractire when cooked, showing a rich creamy culor-and it tastes just as good as it looks, far excelling any other variety in quality and flavor. In season Vick's Golden Nugget follows Golden Bantam, maturing about a week later, when planted at the same time. The plants of Golden Nugget are from one to two feet taller, the ears are larger and there are more ears to the stalk; making the yield double that of Golden Bantam.

Vick's Golden Nugget is grown on our own farm, cultivated with the idea of producing the very best corn obtainable; the seed is carefully cured and you may be sure it is right. You are not absolutely sure of getting Vick's Golden Nugget Sweet corn unless you buy it of James Vick's Sons.

Packet, 10 cents; half pint, 15 cents; pint, 25 cents ; quart, 40 cents.

\section{FIRST EARLY VARIETIES}

Packet, 10 cents; half pint, 15 cents ; pint, 25 cents; quart, 40 cents; except as noted.

Vick's Earliest of All. This is in fact the "earliest of all." Very excellent, tender, and sweet. To market gardeners this variety is of great value, as the first Sweet Corn will bring two or three times the price it commands when the supply becomes general. Also desirable for home garden.

Mammoth White Cory. An excellent sirt, but liest of All. In fact our selection of seed stock and careful growing of this strain make it the largest and best extra early in our list. The stalks are large, while each stalk bears two or more large, fine-shaped ears, twelverowed: remarkable for its good quality for so early a sort. All gardeners who cater to the best trade should plant this variety.

Early Minnesota. An old and popular dwarf variety. Ears fine, of good sw eet quality Desirable for both the market and private garden.

\section{Extra Early Golden Bantam The Golden Bantam is} will stand pianting earlier in the season than other varieties. It grou's about four feet high, bearing one or two medium sized ears of a rich, golden, yellow color. When cooked is exceedingly sweet and tender. Next to Vick's Golden Nugget it is the ideal corn for the home garden.

Packet, 10 cents; $1 / 2$ lpint, 15 cents ; pint, 25 cents ; quart, 45 cents.

Iendel's Early Giant. This variety is one of the largest Early Squect Corns. Is comes in soon after the Cory. Ears eight to ten inches long, 12 to 18 rowed, filled well to the tip with broad whitc, sweet kernels of excellent fiavor. 'Stalks short, bearing one or two ears.

Crosby's Early. Remarkahly early and of best flavor. Ears medium size; twelve-rowed; sweet and thick. Largely grown for canning.

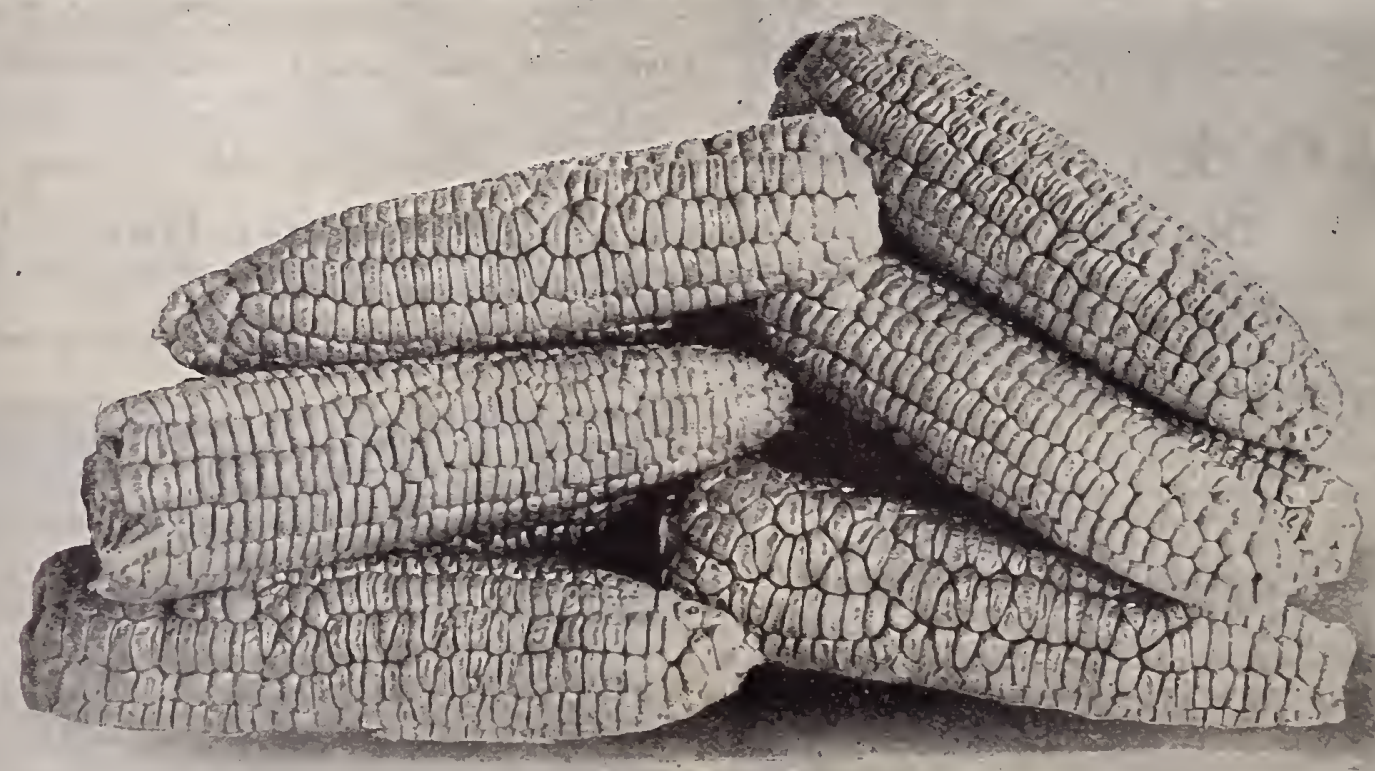




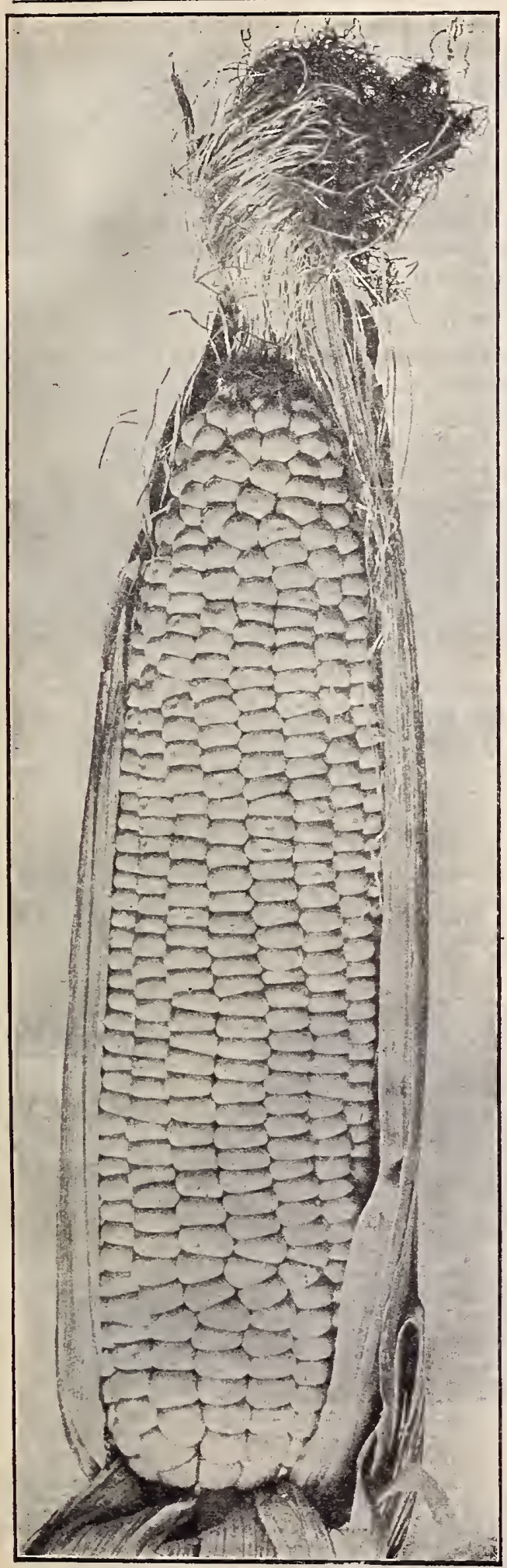

STUWELL'S EVERGREEN

\section{Medium and Second Early}

Packet, to cents; $1 / 2$ pint, 15 cents; pint, 25 cents; quart, 40 cents; except as noted.

Perry's Hybrid Sugiar. A very popular and remarbably long-eared sort for one so early. Ears ready for use a few days later than the Early Cory and Minnesota, but double tbe size of either. liars twelve. rowed; kernels large, tender and deliciously sweet. Stalks of great vigor, about six feet high, with two perfect ears to the stalk.

Early Evergreen. This fine variety is from ten to twelve days earlier than Stowell's; and though it is not quite as tall, it yields large, handsome ten or twelve-rowed ears.

Early Mammoth. The earliest, sweetest, and largest of the mamnoth sweet varieties. Probably no other Sweet Corn will yield as much fodder, and for this reason it is extensively planted, to be fed green or dry'

Potter's Excelsior (Squantum). A well-known sort, extensively grown for market and canning purposes: also used throughout New England in their famous clambakes. It is remarkably sweet, and wonderfully productive.

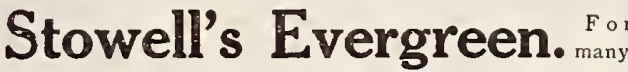

years this variety has stood at the head of the list of late Sweet Corn, and it bids fair to hold the position for years to come. For main late crop, for the family garden, for the market grower and the canner, it is unexcelled. Stalk stroug, bearing two 12-rowed ears with large sweet kernels. Remains in good condition for some time after gathering, thus continuing the season after frosts.

Black Mexican. The ripe grain of this novel variety is black or bluish black, but when in condition for the table looks remarkably white. This is considered the sweetest and most tender of any variety of Sweet Corn.

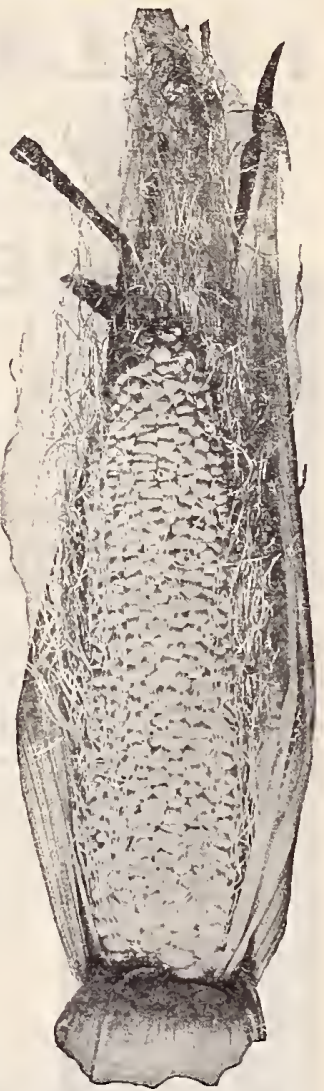

COUNTRY GENTLEMAN
Country Gentleman. A delicious Corn for family use. The enrs are good-sived and produced in great abundance. Its long, small, milky keruels are full of sweetness; the cob is small, and the corn white and tender; it is sure to please. It is somewhat later than Stowell's Evergreen.

Mammoth Late Sugar. Green ears of this variety have been exhibited weighing from two to three pounds. The sweetest and largest of all the mammoth sweet sorts. Valuable on accorint of its yield of stalks for fodder

\section{Sweet Corn}

By express or freight, charges not prepaid

\begin{tabular}{|c|c|c|c|c|c|c|}
\hline Black Mexican & $\$ 25 \$$ & 75 & 8125 & Mammoth Late Sugar. . . \$ & 25 & $\$ 75 \$ 2 \quad 25$ \\
\hline Country Gentleman & 25 & 75 & I 25 & Mammoth White Cory. & 25 & 75 \\
\hline Crosby's Early. & 25 & 75 & 25 & Perry's Hybrid Sugar. . . & 25 & 75 \\
\hline Early Evergreen & $\begin{array}{l}25 \\
25\end{array}$ & 75 & 5 & Potter's Excelsior (Squantum). & 25 & 75 \\
\hline $\begin{array}{l}\text { Early Mammoth } \\
\text { Early Minnesota }\end{array}$ & $\begin{array}{l}25 \\
25\end{array}$ & $\begin{array}{l}75 \\
75\end{array}$ & $\begin{array}{l}125 \\
125\end{array}$ & Stowell's Evergreen & 25 & $7 j$ \\
\hline Golden Bantam. . . & $30^{\circ}$ & 85 & I 50 & Vick's Earliest of All & 25 & 75 \\
\hline Kendel's Early Giant . & 25 & 75 & I 25 & Vick's Golden Nugget. . & 30 & 85 \\
\hline
\end{tabular}

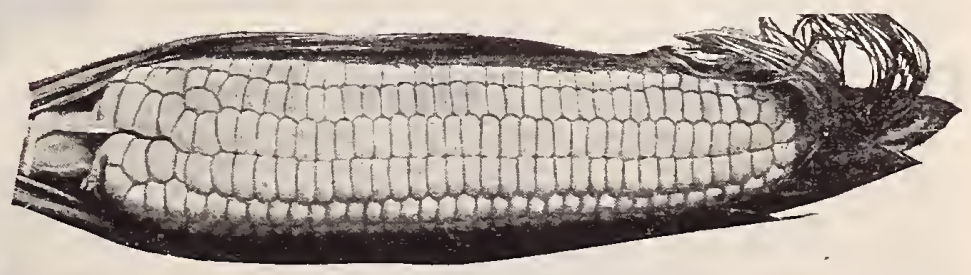

VICK'S EARLIEST OF ALL 


\section{FIELD CORN}

Eight to ten quarts per acre in hills; one bushel in drills; two bushels if sown broadcast, are required per acre.

Please add cost of bags when ordering; $1 / 4$ bu., 8 cents; $1 / 2$ bu., to cents ; 1 bu., 12 cents; 2 bu., 22 cents. Corn by peck or bushel not prepaid.

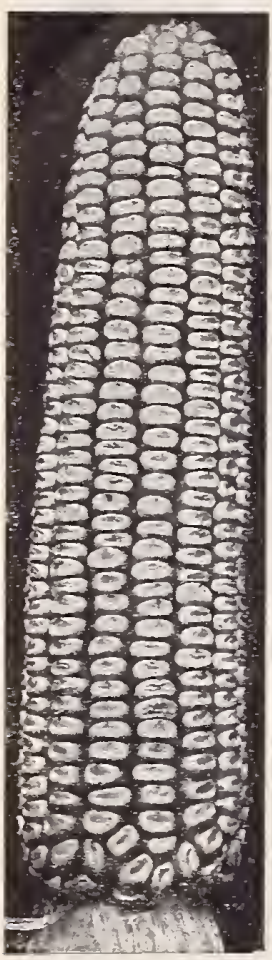

\section{Early Wonder White Dent}

Every good farmer knows that the Dent corns are more valuable for feeding than the Flint sorts. One difficulty has been that most Dent varieties are too late for the extreme North, but

\section{Early Wonder White Dent} overcomes this objection. In 95 days from planting we hare harrested all enormous crop of pure white ears that measured seven to nine inches long. Early Wonder White Dent will grow on poorer soils than yellow corns and give a good stand of strong plants. It comlines the hardiness of the Flint corus with the yielding qualities of the Dents, which fact makes it a profitable variety for either market or feeding purposes. Early Wonder White Dent shells easily and quickly, and as the cob is filled to the tip with large, deep kernels, it yields a large quantity of shelled corn per ear. We have grown Early Wonder White Dent on our own farms, near Rochester, for three years and we consider it the most profitable variety for this latitude, yielding the largest crops we have ever grown.

Quart 40 cents, postpaid. Peck, 75 cents; bushei, $\$ 2.50$; bag of two bushels, $\$ 4.50$; freight or express not paid.

Pride of the North. A sixteen-rowed Yellow Dent variety. Ears eight to ten inches in length; cob very small and red, with grain above medium size and closely set. It produces an enormous quantity of shelled corn to the amount of cob. Stalks six to eight feet, and frequently bearing two ears. An exceedingly early and prolific variety.

Quart, 30 cents; postage paid; Peck, 55 cents; bushel, $\$ 1.75$.

Improved Leaming. Similar to above in every respect, but abnutt one week later in matıring. A very desirable variety for fodder.
Quart, 30 cents, postage paid. Peck, 55 cents; bushel, $\$ 1.75$.

Genesee Valley. with a choice local stock. The cob is white, twelve to fifteen inches in length, and very slender. Tbe grain is a golden yellow, large and compactly set, covering both butt and tip. It is an exceedingly early, hardy, and productive variety yielding on good land from eighty to one hundred busbels of shelled corn per acre. It is easy to husk, and the stalks make good fodder. IVe make a specialty of this variety, growing and selecting it on our farm, Quart, 30 cents; peck, 75 cents; bushel, $\$ 2.50$

\section{Drought-Proof Yellow Dent}

As its name implies will stand more hot, diy weather than any other variety and produce large crops. While it is desirable for all Iocalities where Dent Corn is grown, it is doubly valuable for extreme warm climates. It is of strong growth, maturing in from 90 to 100 days. Ears large, unusually small cob, bright golden kernels. Try it and be convinced.

Quart, 30 cents; peck, 60 cents; bushel, \$2.00.

\section{Iowa Gold Mine It is early, ripening in 95}

(1) days. Can be grown suc. ( Ears are not extra large, but good stze and symmetrical; color, bright golden yellow. Grain is very deep, cobsmall, and therefore dries out very quickly. Quart, 3o cents; peck, 6o cents; bushel, \$2.00.

Yellow Flint, Eight-Rowed. New York State-grown. Valuable for the North on account of earliness and hardiness.

Quart, 30 cents postpaid. Peck, 6o cents; bushel, \$2.00.

Champion White Pearl. Early, thoroughbred White Dent. Ears average sixteen rows, witb very small cob; ripens in 90 th 100 days from time of planting. Very productive, yielding fully as well as the Yelluw Quart, 30 cents, postage paid. Peck, 55 cents; bushel, $\$$ r.75.

Early Mastodon. An improved Yellow Dent, large yield, large gratns, and early ripening. It has the largest number of rows on a cob, and the largest grains of any Corn ever originated; brings a high price in the market, of medium height, grow's rapidly, and ripens in Ion day's. From 170 to 200 bushels per acre have leen produced as far north as latitude $42^{\circ} 30^{\circ}$.

Quart, 30 cents, postage paid. Peck, 55 cents; bushel, $\$ 1.75$.

Golden Beauty. This grand Dent variety is of vigorous growth and immensely productive on rich soil. The ears are of perfect form, remarkable in size, filled to the tip with ten to fourteen rows of remarkably large bright golden grains. Cob very small for so large an ear. Ripens in from rio to 120 days. Stalks ten to twelve feet in herght, with abundant foliage.

Quart, 30 cents, postage paid. Peck, 65 cents ; bushel, $\$ 2,00$.

Improved Early Sheeptooth. (Fodder ('orn). Earlier and better adapted for fodder aud ensilage in the Northern States than the ordinary Southern Sheeptooth. The staiks are twelve to fourteen. feet in height, and enormously productive. This improved sort is generally superseding all known varieties for ensilage purposes. Peck, 40 cents; bushel, \$1.40.

Sweet Fodder. There is nothing better for green feed, or for curing for winter, than Sweet Corn. Cattle highiy relish it, and when fed on it keep in fine condition and give an abundance of rich milk. It is also excellent for soiling. Sow in drills, one and one-half bushels per acre; or broadcast double the quantity. Peck, 55 cents; bushel, $\$ 1.75$.

\section{P O P C O R N}

Shelled_corn, packet, to cents; $1 / 2$ pint, 15 cents; pint, 25 cents; quart, 40 cents.

White Rice. The most popular for general use.

Queen's Golden. Pops creamy white.

Silver Lace. The best white-grained variety.

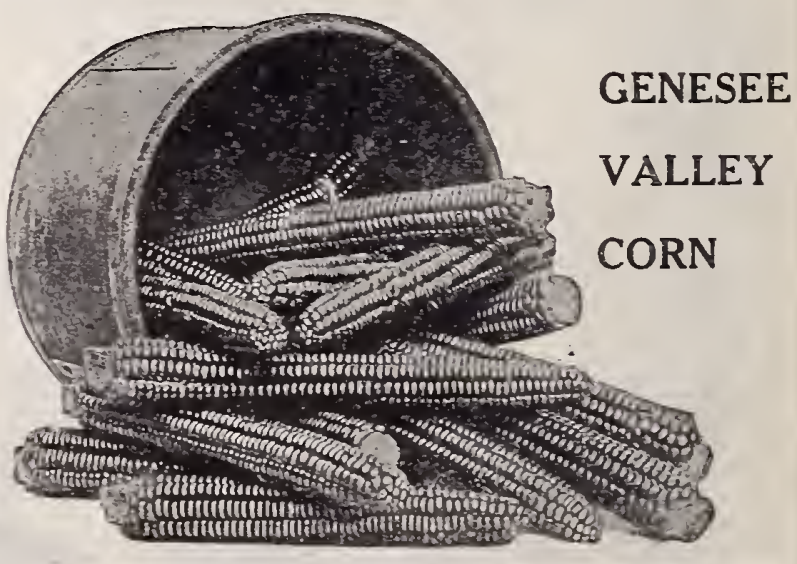

\section{CHICORY}

Sow Chicory seed as early in the spring as the ground can be worked, in drills half an inch deep and fifteen inches apurt, and in mellow soil. The after-culture is the same as for Carrots. In the autumn the plants will be ready for blanching, when it is used as a salad. The dried roots are used as a substitute for and adulterant of coffee. One nunce is sufficient for roo feet of drill. Large-Rooted Long Magdeburg.

Packet, 5 cents; ounce, ro cents; lb., $\$ 1 . \infty$. 


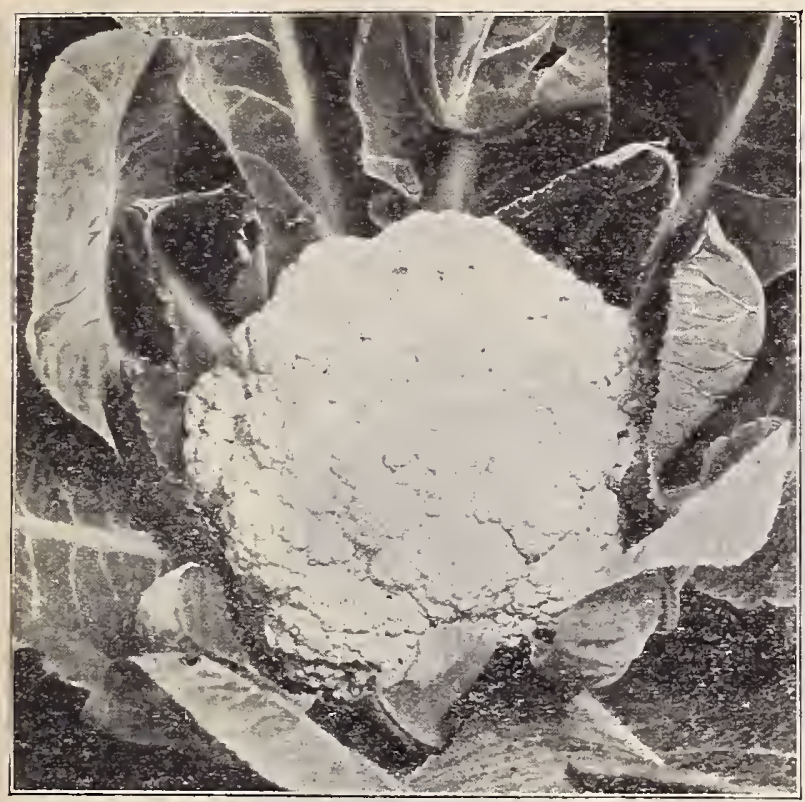

VICK'S IDEAL CAULIFLOWER

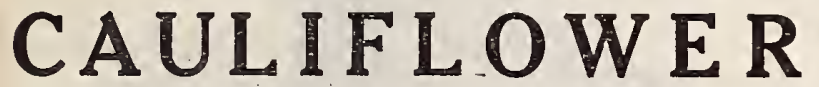

The Cauliflower delights in a rich soil and an abundance of water. Sow seed for an early summer crop in Februaby or March, in a hotbed, and when plants are three or fuur inches high transplant four inches apart in boxes or framcs. In the middle of spring, or as soon as the gardener deems it prudent, the plants can be removed to the open ground: Set plants from two to two and a balf feet apart each way. For late Cauliflower sow seed in a cool, moist place, in this latitude about the first of $M_{1} y$. One ounce will produce about 3,500 plants.

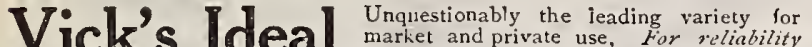
it is superior to any other variety. It is almost sure to head, even under unfavorable circumstances, and will attain to cnormous size under favorable cultivation. Packet, 30 cents; 1/4 Oz., \$1.75; oz., \$5.00.

\section{Vick's Danish Giant "Dry Weather"}

Its main feature is the fact that it will stand an unmsual amount of diy or warm weather and still produce perfect large, sulid heacls. In divtricts where beretofore it has been impossihle to grow Cantiflower. this fine variety has proven a success. It is ready for market or table about a week later than Extra Early Erfurt. Packet, 25 cents; $1 / 402 ., \$ 1.00 ; 02 ., \$ 3.50$.

Early Snowball. Next to our Ideal we can recommend the Snowbitl is one of the earliest and surest heading varieties. Its dwarf habit and sliort onter leaves allow it to be planted very close- eighteen to twenty inches ap.trt. It is well adapted for forcing under glass thronghout the winter and spring. It gives a pure snow-white, medium-sized head.

Packet, 15 cents; $1 / 4$ ounce, 75 cents ; oz., $\$ 2.50$.

Erfurt Earliest Dwarf. This variety will stand the test with any extra early sort. It is very dwarf in habit, producing pure $\mathrm{u}$ hite heads of great solidity and finest quality: quite desirable for forcing or for planting in open ground. For a general all-round market garden variety we can highly recolnmend the Lrfurt strain. Packet, 15 cents; $1 / 402 ., 75$ cents ; oz., $\$ 2.50$.

Early Paris, or Nonpareil. This is a well known standard French variety, producing very carly, goodi-sized, pure white heads, which are tender and delicious.

Packet, 10 cts.; $1 / 2$ oz. 40 cts.; oz., 75 cts.; $1 / 4$ lb. $\$ 2.50$.

Veitch's Autumn Giant. A distinct and valuable late variety for the South, producing large heads, pure white, firm, and compact : and being thoroughly protected by the foliage, remains a long time fit for us

Large Late Algiers. One of the best late sorts for the Sorith largely for fall usc. It is a sure header, and endures uninjured that would materially affect other sorts.

\section{Packet, to cents; 02., 75 cents; 1/4 lb., \$2.00.}

\section{CRESS, Peppergrass}

Cress should be sown in a hotbed or in a shettered spot in the garden, quite thick, in shallow drills, and in a short time it will be fit for cutting. It gives a pungent relish to Lettuce, and other salad plants. A fresh lot slould be sown every week, as it matures very rapidly and is useful only when young.

Packet, 5 cents; oz., 15 cents ; 1b., 75 cents ; except where noted.

Fine Curled. Superior:

Broad-Leaved Garden. Sometimes used for soups

Australian. Leaves delicate green; flavor nild and fine.

Water. Does wel! without care in mucky situations, or on the edre of streams, in shallow water. Packet, 1o cents; oz., 30 cents; 1b., \$3.00.

\section{DANDELION}

Sow as early in spring as the weather eighteen inches apart, covering the seed one-fourth of an inch deep. Thin the plants to twelve inches apart. Keep clear of weeds, and the following spring the leaves will be fit to cut. One ounce is sufficient fo: 100 feet of drill.

Improved Thick-Leaved. Leaves thicker than Arlington and not so finely curled. Packet, ro cents; oz., 50 cents.

Common. Packet, 5 cents; oz., 25 cents.

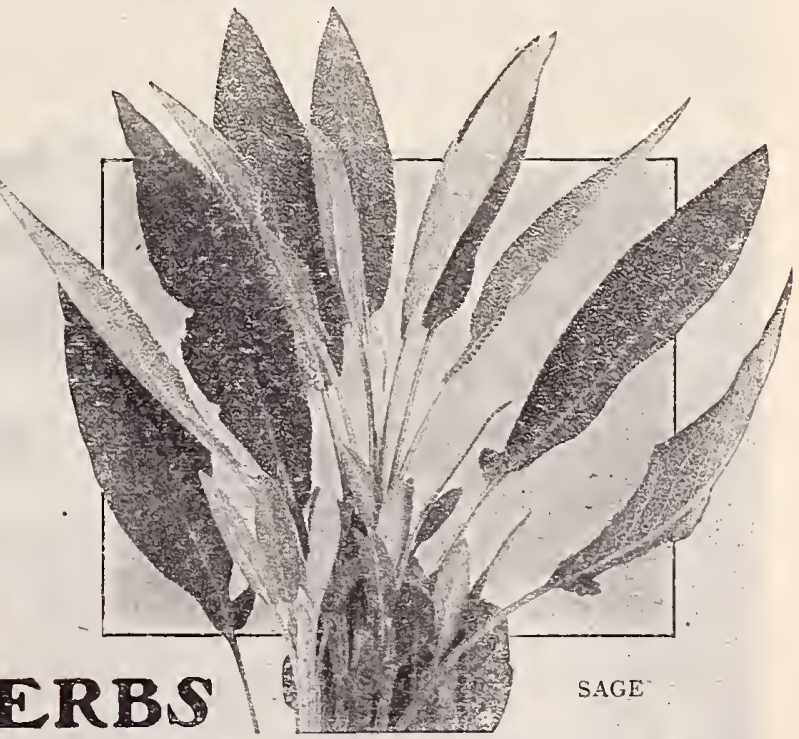

A very small space in the garden will give all thc herbs neęded in the family. The culture is very simple. The best way is to make a little seedbed in the early spring and set the plants out in a bed as soon as large enough. As a general rule it is best to cut the hcrbs when in flower, tie them up in small bunches, and hang in the shade to dry. We give a list of the herbs generally cultivated and prized. Of some linds we furnish roots, as will be seen below :
Anise, per lb., \$1.00: per ounce, ro ceirts, PKT
Balm, per ounce, $3^{\circ}$ cents
Basil, Sweet, per ounce, 20
Borage, per ounce, 20 cents
per ollince, 10 cents
Coriander, per lb., 75 cents:
Dill, per innce, 1o cents.
Fennel, Large Sweet, per ounce, io cents
Hoarhound, per ounce, 30 cents.
PKT.
Hyssop, per onnce, 25 cents. . . . . cis.
True, (Lavendula vera, , ounce, 25 cents
Marjoram, Sweet, per ounce, 20 cents.
Rosemary, per ounce, so cents
Rue, per ounce, 20 cents
Saffion, per ounce, xo cents
Sage, per lb., $\$ 2.00$; per ounce, 20 cents .

20
5
5
5
5
5
5
5
5
PKT.
Savory, Summer, per ounce, 15 cents . . . . . 5 Sorrel, French, per ounce, 15 cents.
Tansy, per ounce, 30 cents.
Thyme
Broad-Leaved,orWinter, pero7, 30 cts
Summer, per ounce, 30 cents.
Wormwood, per ounce, 30 cents.
Lavender Roots by mail, each, $r$ cts ; wo for 2 : $c^{5}$ Sage Roots by mail, each; 15 cts.; iwo for 25 c.

nill give all the herbs needed in the family. T
cut in a bed as soon as large elrongh. As a gener
ry. We give a list of the herbs generally cultivated
ceirts, ... 5 . Hop Seed, per ounce, \$1.50. 


\section{Twelve

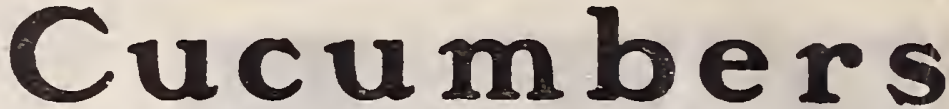

We have tested these twelve varieties on our trial grounds with many others; we have had the opinion of customers, and we believe they are far ahead of others for Home and Market Gardens $\mathrm{N}$ this latitude it is useless to plant in open ground until nearly the first of June. Make hills two feet in diameter and about six feet 1 apart, and enrich them with well-rotted manure. Plant a dozen or more seeds, covering half an inch deep. When all danger from insects is over, pull all but three or four of the strongest plants. One ounce for fifty hills; two pounds per acre when planted in hills. Packet, 5 cents; ounce, ro cents; If pound, 35 cents; pound, $\$ 2.25$; except as noted.

\section{Vick's Early Perfection White Spine}

\section{It excels in earliness, and} is one or the best for either the home garden or forcing; also extensively grown for pickles. This most valuable strain is grown from stock seed, produced on our own farm, our selections being made from the choicest and most perfect fruits only. Packet, ro cts.; 0z. 20 cts.; lb., \$I.50.

\section{Vick's Improved Early White Spine}

Very popular in all sections of the country. Flesh tender
form in size, straight and dark green, with few white spines.

Early Green Cluster. A short pale green variety. Fruit borne in clusters near the root: rather prickly
and very satisfactory for pickles.

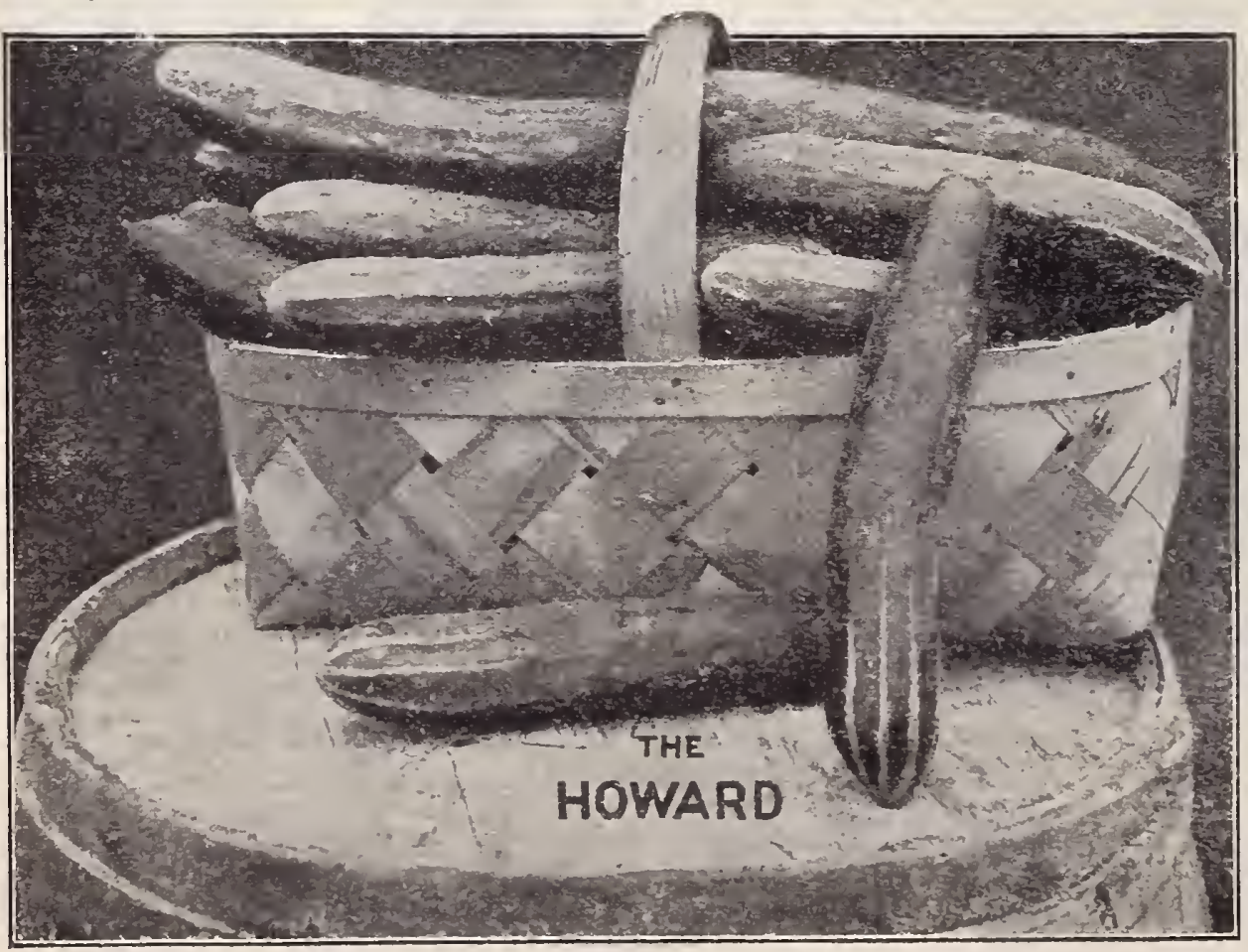

Chicago or Wosterfield Pickling.

Fruit medium length, pointed at each end, with large and prominent spines; color a deep green. It combines all the good yualities of an early Cucumber, and is much esteemed by Clicago market gardeners, and grown extensively for the large pickling establishments in that vicinity.

Green Prolific or Boston Pickling. A distinct variety. A favorite with pickle growers and commercial gardeners, and good for table use. Quite productive. Fruitsmall, uniform in size.

\section{The Howard}

A handsome and rery productive forcing variet5, making fruit of the finest quality and shape, with exceedingly small seed cavity. It is also an extra fine ppell ground variety, combining the good yualities of $1 \mathrm{~m}$ proved Long Green with the fine shape and color of the White spine; in fact it is a cross between these two excellent varieties, and is used for forcing by our Rochester market gardewers, on account of its carliness, size, and rich dark green color. Packet, ro cents: 1/2 oz, 20 cents ; oz, 35 cents ; $1 / 4$ ib., \$1.25.

Early Frame or Short Green. An excellent sort both for table use and for pickling. Fruit straight, handsome, sula!ler at e:tcli end, bright green, flesh tender and crisp, and mahes tine pichles.

Thorburn's Everbearing. Small size, very early, and enormously productive, ind valuahle as a green pickler. It continues to flower and produce frtit until killed by frost, whether the cucumbers are picked off or not. Remarkably solid, with very few seeds, and of ine quality. Invariably of perfect form, even when small. Packet, 5 cents; oz., 15 cents; ib., \$1.25. 


\section{CUCUMBERS-Continued}

Packet, 5 cents ; ounce, Io cents ; 1/4 pound. 35 cents; pound $\$$ r.25; except as noted.

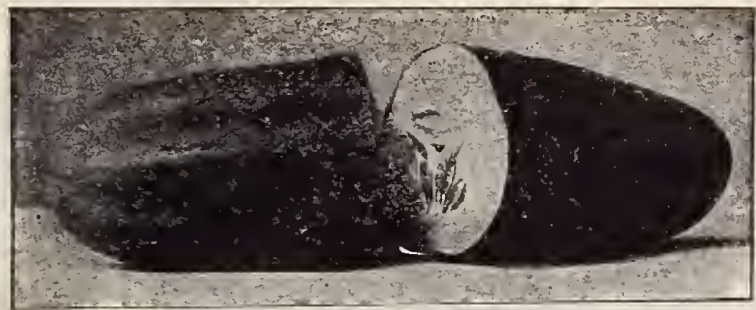

COOL AND CRISP CUCUMBER

Cool and Crisp. A strain of the White Spine, but longer and more cylindrical. Very early aud exceedinglyp prolific. While it is esteemed most highly as a pickling sort, it is one of the very best for slicing, being tellder, crisp, aud of fiue flavor.

Early Russian. Earlıest and hardiest small Cucumber in cultivation, being only three to four minches long; thick and oval in shape, and produced in pairs. Solid, with few seeds.

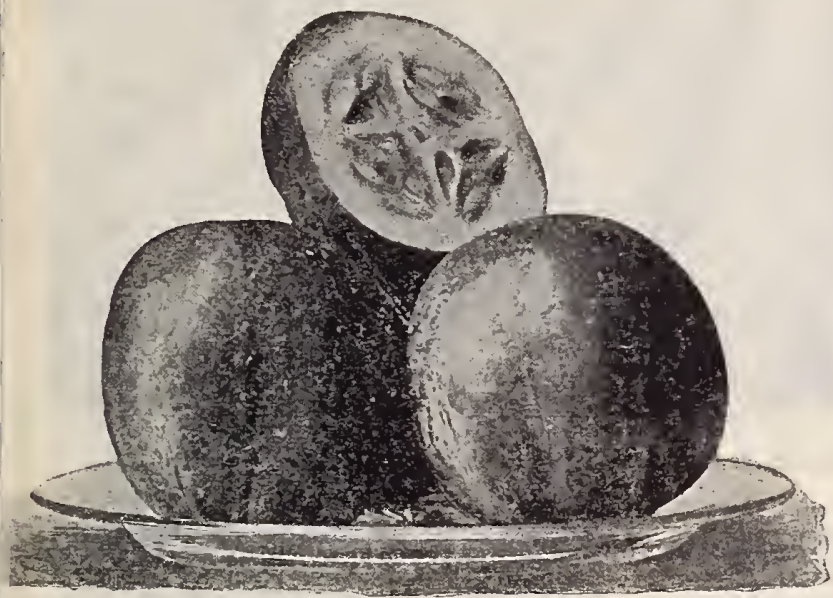

VICK'S LLMON CUCUMBER

\section{Vick's Lemon Cucumber}

The Lemon Cucumber is nearly round, with yellow and green markings and smooth slin, similar to the Lemon. The flesh is tender, crisp, and possesses a sweetness and flavor surpassing all other Cucumbers. The fruits are from two and a half to three inches in diameter, and very attractive in appearance. For pickling, either when green or ripe, they are unexcelled. They should be used for the table just as the fruits are turning yellow. Customers who grow the Lemon Cucumber say they prefer it for quality and productiveness to any other variety.

\section{Packet, Io cents; ounce, 25 cents.}

\section{Foreign Cucumbers}

\section{Used Chiefly by Market Gardeners}

Japanese Climbing. A strong and vigorous grower; and while all Cucum. bers are rumning or creeping vines, this variety attains mearly twice the length of ordinary sorts, and can be grown on trellises, fences, or poles. The fruit is from ten to twelve inches ir. length and of excellent quality either tor slicing or pickling. Packet, 10 cents; oz., 20 cents; 1b., \$2.00.

Rollison's Telegraph. The very best of all imported sorts; twenty-six 10 thirty inches long. Packet, 25 cents.

Noa's Forcing. Most productive sort; thirty to thirty-six inches long Packet, 25 cents.

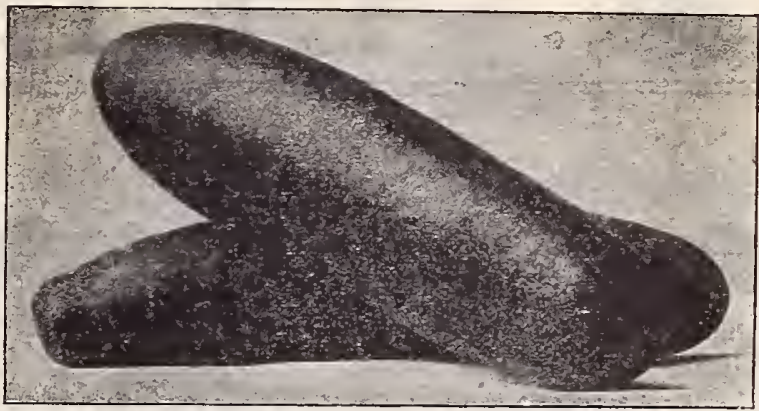

IMPROVEU LONG GREEN CUCUMBER

\section{Improved Long Green. A well-known}

about twelve inches in length, of most excellent quality, and when young makes the best of pickles. When ripe it is the best of any for sweet pickles. Vines vigorous and very productive. Our strain of this valuable sort is unsurpassed by any, being carefully selected from the best fruits.

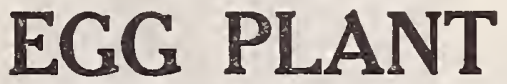

Those who have no hotbeds can sow a few seeds in boxes in the house, where a temperature of $75^{\circ}$ can be maintained. Plant out early in June two and a half feet apart. One ounce will produce about 1,500 plants.

Black Beauty. Distinct and nine. The fruit is quite as large as Improved N. Y. Purple, and from len day's to two weeks eariier than that variety. It is very altractive in appearance, and of excellent flavor. Packet, Io cents ; 1/2 oz., 25 cents ; oz., 40 cents ; 1/4 lb. $\$ 1.10 ; 1 b ., \$ 4.00$. Improved New York Purple, Spineless. The standard for home use and market. Fruit very large, productive, and of the highest qualiny. Packet, Io cts.; $1 / 20 z ., 25$ cents ; oz., 40 cents; $1 / 4 \mathrm{lb} ., \$ 1.25 ; 1 \mathrm{~b} ., \$ 4.00$. Early Long Purple. Cylindrical, eight or nine inches long. Earlier hardier, and more prolific than the larger kinds.

Packet, 5 cents ; $0 z ., 20$ cents ; 1b., $\$ 2.00$.

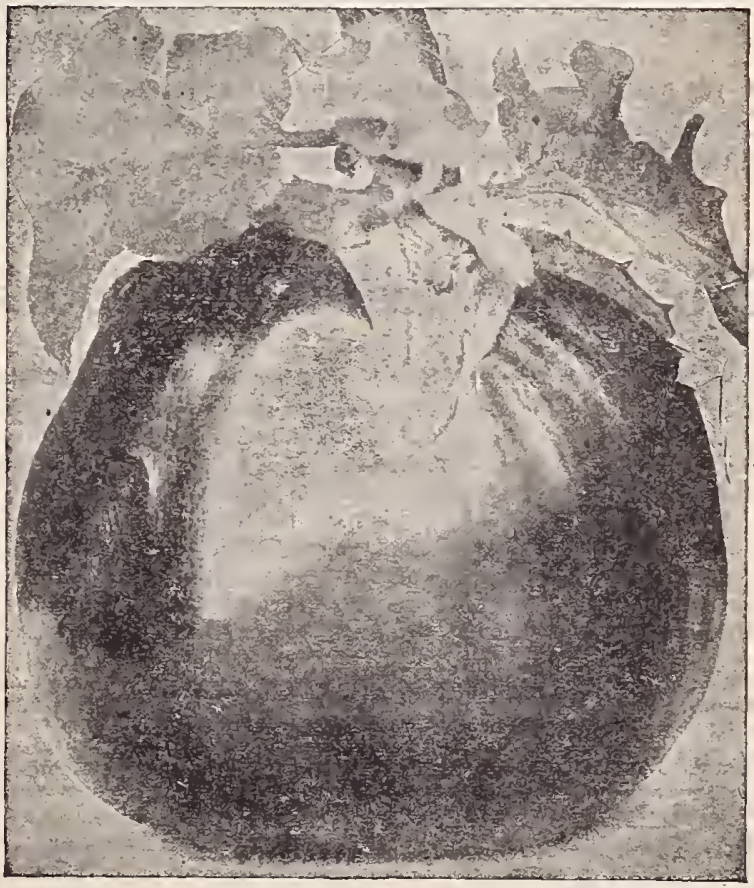

EGG PLANI, INIPROVED NEW YORK PURPLE SPINELESS 

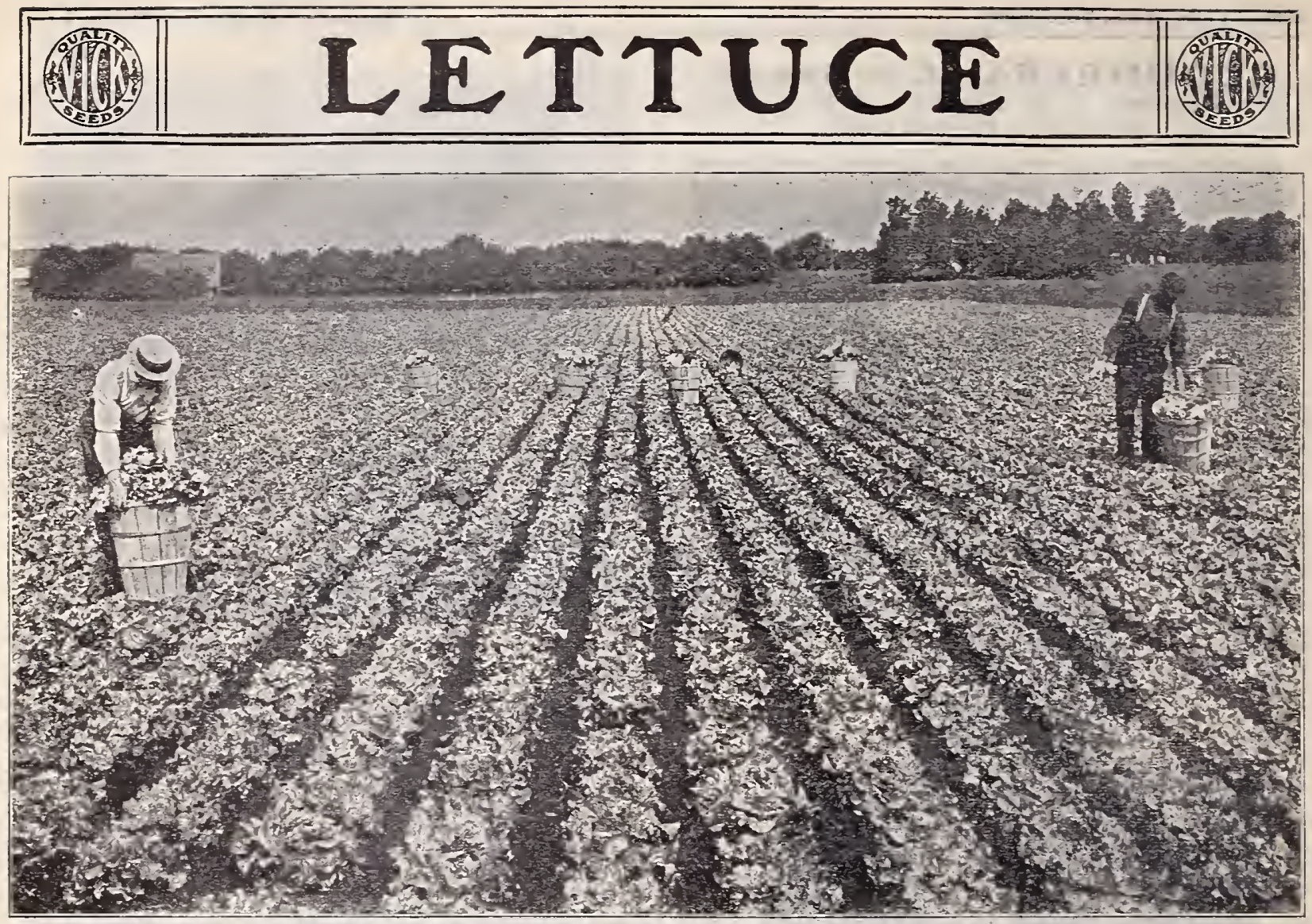

Field of BIG BOSTON-LETTUCE Grown from Vick's Selected Strain

SOW in the open ground as early as possible, barely covering the seed. If a hothed is used, let it be started quite early. Give but little heat, and on fine days plenty of water and air. Let plants be alout four inches apart in the bed. As they increase in size thin them out, or they will become weak. One-half ounce will sow Ioo feet of drill.

Packet, 5 cents; oz., 15 cents; $1 / 4$ lb., 35 cents; 1 b., $\$ 1.25$, unless otherwise noted. Market growers are invited to ask for special prices.

\section{Cabbage or Heading Varieties}

\section{BIG BOSTON Vick's Special or Selected}

\section{Strain. The outer leaves are a ricli green, crisp and tencler} and the center of the head a beautiful butter-yellow and white, very fine grained, and packed as close as a cabbage. Big Boston is more extensively used for market than any other variety, many acres being grown in the vicinity of Rochester alone. Plants are sure headers, and stand a long time before seeding. This is also one of the best varieties for the home garden.

Packet, ro cents; ounce, 25 cents; 1/4 1b., 40 cents; 1 b., \$I. 50.

Vick's Premium Cabbage. An oll favorie, excellent for all uses and seasons. Heads well: remaining in good condition for a long time withont
going to seed. Heads medium to large. Color bright green.

Vick's Royal. A fine variety, largely used in the Paris markets. The seed we offer comes direct from the originator. It produces a mediumsized licad of a beautiful golden color, crisp ais 3 tender.

The Keene. the Boston Forcing and other popular market sorts. It is extremely hurdy and does not burn, nor blight in any way. We are pleased to offer this excellent Packet, Io cents; 0z., 30 cents; 1/4lb., 60 cents; lb., $\$ 2.00$.

Cooper. Named after one of Rochester's leading market gardeners. It is sown in the fall and the young plants cuvered with stable litter just before the first hard freeze. In the spring the covering is removed. It soon variety is equally as good for spring and summer suwing.

Crisp as Ice. A splendid and distinct Cabbage I.ettuce. we ome shape, and solid. Whell cut open they have a rich creaniy yellow The leaves are so tender and britte as to marrant the llame, "Crisp as lce." ariegated with dark bronze and green.

Golden Queen. A fine quick growing hearl Lettuce, and one of the hest sorts for early ontcloor planting as well as for growing under glas's. The colo The heads are so solid that there is 110 waste whatever. ant they re.illy contain more substance than many virieties showing double the size.

Imperial White Cabbage.

cellent for family uve and market. It is the head. Heads large and extremely solld, of a lighegreen color: very best sumner lettlices in cultivation for the home garden. 


\section{Lettuce, Heading Varieties continued \\ Packet, 5 cents; oz., 15 cents; 1/4 lb., 45 cents; 1b., $\$ \mathrm{r} .50$; unless otherwise noted.}

Tennis Ball, or Boston Market. A well known forcing variety. One of the earliest and best heading sorts.

Improved Hanson. A standard summer Lettuce; none more reliable for out-door cultivation. The heads grow to a remarkable size, and are very solid. The outer leaves are a bright green, while the inner head presents a white appearance, as though blanched; tender and crisp, and free from any unpleasant bitter taste. It is slow to seed, and is an ideal Summer Lettuce.

May King. A new variety highly recommended. Mledium-sized round solid heads, light green in color, the heads turning to a rich golden yellow; as the plants develop; fine buttery flovor.

Salamander or Satisfaction. Forms large, solid, compact heads, resisting summer heat ard remaining long in head. Leaves smooth, thick, and very tender; the inner head blanching almost white. An excellent spring, summer, or fall variety. Invaluable in the Southern States.

\section{Curled or Loose-Leaf Varieties}

Grand Rapids Forcing. There is no better forcing variety - among the curled-leaved sorts than Large, beautiful leaves, very crisp and tender. Frequently a house full of this Lettuce will average one half pound to a plant.

Black-Seeded Simpson. The most popular sort of all the non-heading varieties. One of the best for use under glass as well as for early outdoor planting. The plants form large, loose heads; outer leaves a light, yellowish green, with inner leaves blanched almost white. Resists the heat and remains long in a good edible condition.

Early Curled Simpson (Silesia). Forms a close compact mass of leaves that are large and broad, crimped and blistered, and light green in color. Not desirable for forcing with bottom heat. It is however recommended for planting in cold frames, and extensively grown in the open.

Prize Head. Is very large; stained with red; outer leaves curled; very crisp and tender ; slow in rumning to seed.

Other Standard Varietie; of Lettuce: Deacon. Denver Market.

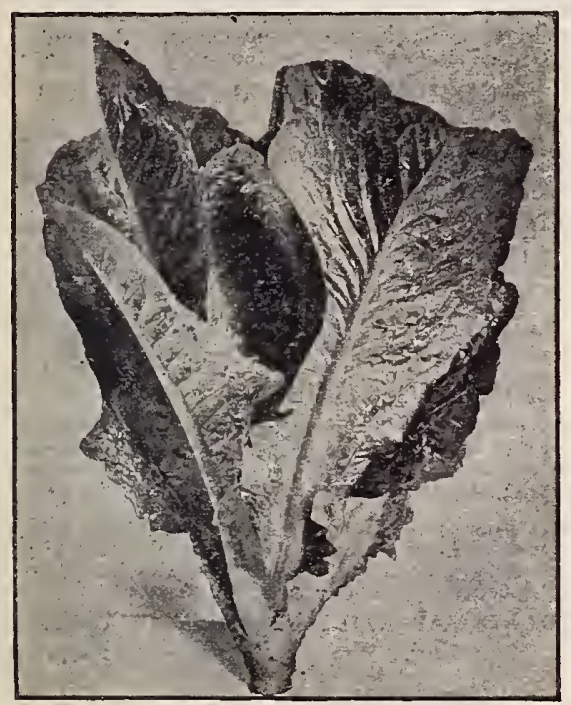

Cos or

\section{Romaine}

\section{Lettnce}

Paris White Cos

The Cos Lettuces are quite distinct, and are popular on account of their tendercrispleaves and delicate ff avor The leaves are long and narrow, and need to be tied up, when they soon form solid heads, and bleaeh snow white.

PARIS WHITE COS LETTUCE

\section{ENDIVE}

Endive is an excellent autumn and winter salad. Sow seed late in the spring or even as late as July, in shallow drills, fifteen inches apart, and when plants are strong, thin out to about a foot apart. To blanch, gather up the outer leaves over the center of the plant, and tie them together at their tips. Sow one ounce to roo feet of drill.

Packet, 5 cents; oz., ro cents; 1b., 1.25 .

Moss Curled, Foliage very dense and beautifully fringed.

Green Curled. The hardiest variety. Leaves dark green, finely cut; easily blanched to a fine white.

White Curled. Foliagesomewhat coarser than the Green Curled, moderately dense, pale green.

Broad-Leaved Batavian.' (Escarolle.) Leaves broad, thick, somewhat wrinkled.

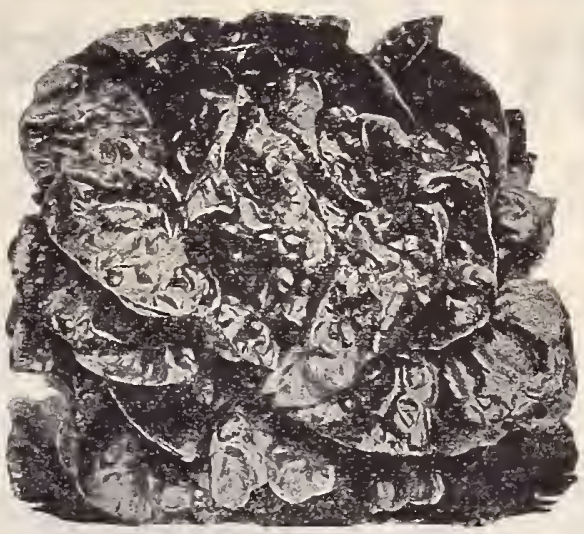

LETTUCE, MAY KING

\section{FENNEL}

To those who are looking for "something different" we commend a trial of the giant Sweet Fennel. It is an easily cultivated annual, maturing quickly from seed sowed in spring. The thickened bases of the leaf-stalks form a bulblike growth, which is blanched by earthing up like celery. It is cooked in various ways and will be found a pleasing addition to the vegetable list. Giant Messina. Packet, 5 cents; one-quarter ounce; lo cents.

\section{KOHL RABI}

Kohl Rabi is sown for general crop in the spring, like the Turnip, in drills, or may he transplanted like Cabbage. For winter table use, sow middle of June. Gather when small and tender, as later it becomes tough and stringy. The stem, just above the surface of the ground, swells into a bulb something like a Turnip. One ounce will sow 200 feet of drill.

Early White Vienna. Delicate; much prized for forcing.

Packet, 5 cents; oz., 25 cents; 1/4 lb., 60 cents; lb., \$2.00.

Early Purple Vienna. Another forcing variety, similar to above except in color. Packet, 5 cents ; oz., 25 cents; $1 / 4$ lb., 6o cents; lb., \$2.00.

Large Early White or Green. Used for feeding stock.

Packet, 5 cents ; oz., 20 cents ; 1b., \$1.50.

\section{LEEK}

The Leek is a mild onion-like plant that should be better known. The fong, bianched necks are milder and more tender than the onion. The green tops are esteemed superior to the onion for flavoring soups, etc., their strong odor disappearing in cooking. Sow as for onion.

Monstrous Carenton. A new and valuable strain of the easily blanched and of the finest quality. Packet, Io cents; ounce, 20 cents.

Broad Flag. An old favorite. Large, hardy, and productive,

Packet, 5 cents ; oz., 15 cents; $1 / 4$ lb., 40 cents ; 1b., $\$ 1.25$.

Musselburg. The largest variety. Hardy. Flavor very mild. Packet, 5 cents ; oz., 15 cents ; $1 / 4$ lb., 40 cents ; 1b.. \$1.25.

\section{HORSERADISH}

Horseradish is grown from pieces of the roots. Mark off rows two and one half feet apart, in rich, moist, well prepared ground; set the pieces of roots eighteen inches apart in the rows, the small end down, and the top, one to three inches below the surface. Cultivate thoroughly until the tops cover the ground, when their shade will keep the weeds down.

Roots, 3 for Io cents; per doz, 25 cents, postpaid. By freight or express at purchaser's expense, 75 cents per 100. 
can be successfully grown in a much larger territory than the Water. melons. They do not require so long a season for maturing their fruit as do the latter, and therefore can be planted in more northern latitudes. Neither do they require the warm, sandy soil of the Water. melon. They can be grown in colder and heavier soils with but little manuring, which should be placed in each hill. The hills should be six feet apart. Do not plant until the ground has become warm and dry. One ounce will plant fifty hills. Two pounds are sufficient for an acre, when plaisted in hills.

Packet 5 cents; oz., I5 cents; $1 / 4$ Ib., 40 cents, 1 b., $\$ 1.25$ except as noted.

The Irondequoit Muskmelon originated on the farm of James Vick's Sons, and was introduced by us in 1889 . The name was given in honor of

Rochester's

famous gardening issrict.
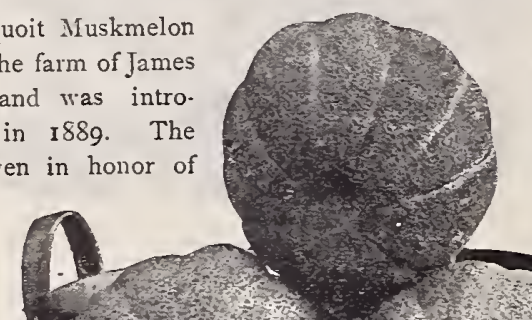

Rocky Ford. This is the most popular of the small Melons being extensively grown and shipped in car-loads for the markets. It is one of the finest early Melons, and one of the best for market gardeners and shippers as well as for the home garden. It is oval in shape, slightly ribbed, and covered with a coarse netting. The flesh is thick, green in color, very sweet and juicj, and solid clear to the rind.

Emerald Gem. Tbe fruit of this really pretty Melon is small to medium, globular in form, flattened at tbe blossom and stem ends; skin smooth and slightly ribbed. It shows a rich emerald green color with narrow stripes of light green in the ribs. Flesh very thick, ripening close to the rind, of a deep rich, salmon color, deliciously flavored and of superior quality. "The fruit should be picked as soon as it will separate readily from the vine, and kept in a cool place until needed. If left on the vine the skin becomes yellow, and the flesh soft and tasteless.

Paul Rose or Petosky. This sort has given perfect satisfaction to all growers, both for market and home garden. It is a cross between the Osage and the Netted Gem, combining the sweetness of the former with the fine gray netting of the latter, making it a handsome Melon. 'The flesh is thick and firm, a deep salmon or orange color; most delicious and appetizing.

Jenny Lind. This is one of the oldest varieties of Mluskmelon. The fruit is small and round, flat on both ends, deeply lobed, and finely netted. The flesh is green and luscious. It comes into market first of all.

\section{MEDIUM-SIZED VARIETIES}

Vick's Prolific Nutmeg. The vines are hardy and vigorous. Fruit medium size, round, slightly flattened at both ends, ribbed, with distinct netting; flesh green, thick, solid, and of delicious, spicy flavor.

Osage, or Miller's Cream. A remarkably fine variety, and a very profitable sort for market gardeners. It is of medium size, oval in form, dark green in color, handsomely netted, and slightly ribbed. The flesh is extremely and uniformly thick, of firm texture, ricb salmon in color, highly flavored and delicious to the rind. Cavity verg small. Good keeper and shipper.

\section{Vick's Irondequoit}

Color. The fiesh is a beautiful dark orange, and the closely netted skin is pale yellow when ripe, giving it a most attractive appearance when exposed for sale or when cut for the table.

Size. The fruit is unusually large, in fact it is one of the largest varieties grown.

Shape. The shape is well shown in the illustration. The Melons are distinctly ribbed and beautifully netted, The Hesh is solid and very thick, having but a small seed cavity.

Flavor. The flavor of a well ripened "Irondequoit" is delicious, sweet, rich, spicy and melting-the very highest quality in Muskmelons. Added to large size and attractive appearance the combination is absolutely the best obtainable.

The seed we offer is true to type in all respects. It is grown under our personal supervision by one of the most skillful Melon growers in Monroe County. Great care is taken in harresting the crop to exclude all Melons not of the highest grade.

The "Irondequoit" has succeeded so well under such a wide range of conditions that we confidently recommend it to our customers as the best all-around melon either for the home garden or for market. For many years it has held the Rochester market to the exclusion of all other varieties.

Packet, Io cents; $1 / 20 z, 30$ cents ; oz., 50 cents ; it lb $\$ 2.00$; pound $\$ 7.50$.

\section{LARGE VARIETIES}

Extra Early Hackensack. This is a very popular sort, producinglarge, handsome, and extra early Melons of best quality. Fruit nearly round, deeply ribbed, and very coarsely netted. The flesh is green, of most delicious flavor. Packet, 5 cents; 0z., I5 cents; $1 / 41$ b., 45 cents; 1 b., $\$ 1.50$.

Montreal Nutmeg. Fruit of the largest size, often attaining a weight of fifteen to twentr pounds. Shape nearly round, flattened at the ends, deeply ribbed: flesh remarkably thick, green, melting, and of the finest flavor. Packet, 5 cents ; oz., I5 cents ; $1 / 4$ 1b., 45 cents ; lb., \$1.50.

\section{OTHER STANDARD VARIETIES OF MUSKMELON}

Champion Market Large Hackensack Surprise

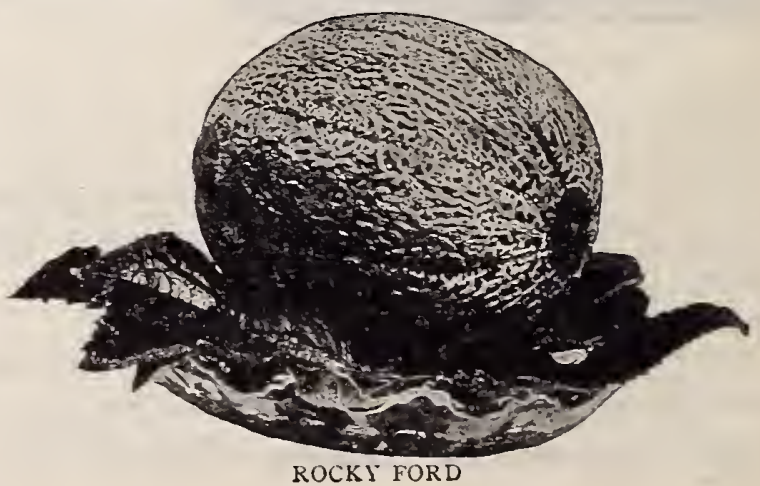




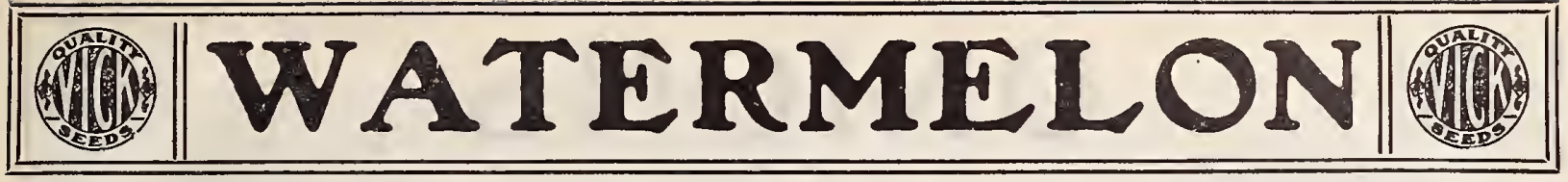

Plant in hills eight or ten feet apart. The same culture as recommended for Cucumbers will insure success. One ounce of seed will plant thirty hills, and four pounds an acre, with hills eight to ten feet apart. Allow three or four plants to remain in each hill. Packet, 5 cents; ounce, ro cents; one-quarter pound, 30 cents; pound, $\$ 1.00$; except as noted.

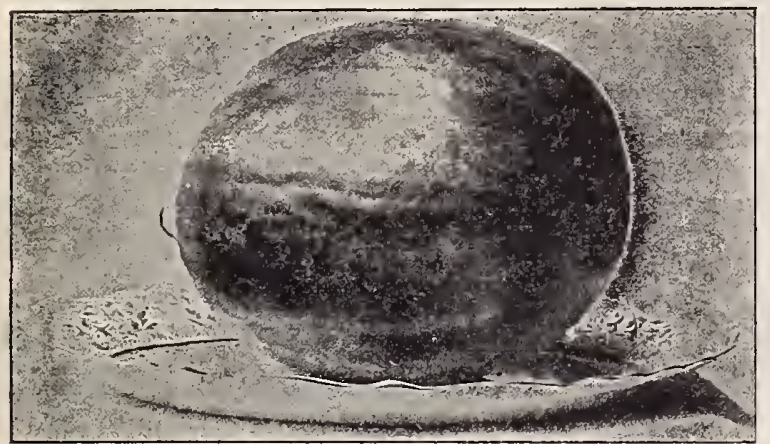

COLE'S EARLY-THE AMA'IEUR GROWER'S FAVORITE.

SW eet IR eart oue of the best varieties righ mality and envy for North. Large size, nearly globular in shape; skin a bright mottled green; rind thin; flesh bright red, firm, and solid to the center; heavy, but crisp, melting, and exceedingly sweet. A good keeper, and improves in quality for a long time after ripening. Vine vigorous and productive, ripening its fruit early.

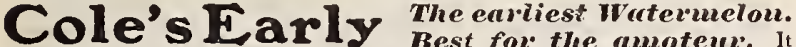
is not only the earliest variety in cultivation, but continues to bear enor. mously throughout the season. The fruit is nearly round; rind thin and brittle, hence not desirable for slipping; flesh deep red and of extremely delicate texture, sweet, juicy, and delicious.

\section{Kleckly Sweets considered the finest fintred} ten to tivelve inches in diameter; skin dark green; flesh bright red, extremely sweet, melting, and luscious. Ripens close to the rind, which is only about one-half inch in thickness. Not a shipper, but highly recommended for the home market and family garden.

Florida Favorite. An excellent variety of large size. Shape oblong skin mottled with alternate dark and light green stripes: rind thin but firm flesh bright crimson, very crisp, and deliciously sweet. Ripens early.

McIvor's Wonderful Sugar. Of Southern origin, and is one of the very hest Melons in cultivation. The Melons attain great size; oblong in shape, the rind showing broad stripes of light and dark green. The flesh is a rosy pink, perfectly solid, crisp, and of delicioun flavor. Ex. ceedingly sweet and juicy.

Dixie. In shape about one-third longer than thick: color of skin dark, green and beautifully striped; rind thin, but remarkably hard; flesh bright scarlet, sweet and juicy.

\section{Vick's Early}

A Melou prized for the shape, smooth, with a very dark skın, rather small in size; flesh bright pink, solid, and sweet. Vines strong, bearing freely, thus making it a desirable variety for the home gardener, and the man who grows melons for the market.

Ice Cream or Peerless. The old but extremely popular home market Melon. Medium in'size, almost round; the skin a pale green; flesh bright scarlet, fine-grained, solid to the center, sweet, crisp, and melting. Its delicious fiavor entitles it to the name of Peerless.

Prize Jumbo. Immense in size. The common weight of this Melon is sixty to eighty pounds. The rind is hard and firm, which makes it a superior variety for long-distance shipping. In shape it is nearly round: color solid dark green; flesh deep red and of fine quality.

Georgia Rattlesnake. One of the largest varieties, and stands shipping long distances. Fruit of good size, oblong in form, distinctly striped and mottled; flesh bright scarlet and of excellent quality.

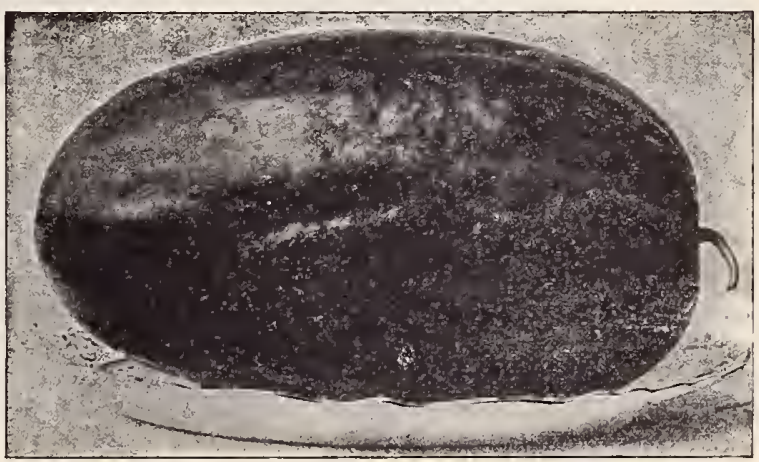

KLECKLEY SWEETS-A HOME GARDEN MELON

Citron. For Preserves. This variety grows uniformly round and smooth. It has a handsomely striped and marbled skin of light green. Used only for preserves and pickles, and not for eating in the raw state. Very prolific

OTHER VARIETIES OF WATERMELONS.

We can supply at the uniform price of: Packet, 5 cents; ounce, Io cents one-quarter pound, 25 cents; pound, 75 cents.

Black Diamond, Fordhook Early, Cuban Queen.

\section{MUSHROOMS}

Mushrooms can be grown in any dark room or cellar, where the temperature can be maintained at $50^{\circ}$ to $60^{\circ}$. If the temperature is right in six or eight weeks yoll may expect the first crop of Mushrooms. One Brick of spawn is enough for a bed $3 \times 3$ feet. Directions for preparing the beds will be sent with "New Culture" Spawn. Positively fresh, pure virgin which these bricks are made is "spawned" directly from lieavy, meaty mushrooms. Bricks, 35 cents each, postpaid. Five bricks. \$1.00; ro bricks, \$1.70; by express, charges not prepaid.

For books on Mushroom growing see page 40.

\section{MUSTARD}

Ostrich Plume. Exceedingly ornamental as well as useful. The leaves are long, ruffled, frilled, and curved as gracefully as an ostrich plume. For salad it is better than any other variety, and for boiling it is superior to spinach. Packet, 5 cents ; oz., ro cents.

White. Fine for salad or culinary purposes. oz., locents $\quad$ Packet, 5 cents , $1 / 2$ lb., 25 cents; lb., 40 cents. Jield until frosty weather. Packet, 5 cents; oz., Iu cents ; lb., 50 cents.

\section{OKRA OR GUMBO}

A large, vigorous, tender plant, cultivated in the South for its young seed pods, which are very nutritious, and are used in soups, stews, etc., and especially for making gumbo soup. Should be nore generally grown in the North wherever it is warm enough for Sweet Corn. About the last week in May sow seed thinly, in drills one inch deep and three feet apart. When well up. thin the plants out to one foot apart in the row. Gather the pods when quite young (about an inch and a half long), before woody fibre is formed. One ounce of seed will sow fifty feet of drill.

White Velvet (White Creole). Pods round, smooth, much larger than other sorts; produced in great profusion

Packet, 5 cents ; oz., Io cents ; $1 / 1 \mathrm{lb}$., 20 cents ; lb., 55 cents.

Perkin's Mammoth Long Pod. A dwarf but enormously produc-

tive variety. Pods long, slender, deep green, and remain tender much longer

than most sorts. Packet, 5 cts,; oz, ro cts.; $1 / 4$ lb., $20 \mathrm{cts}$.; $1 \mathrm{~b} .65 \mathrm{cts}$. 


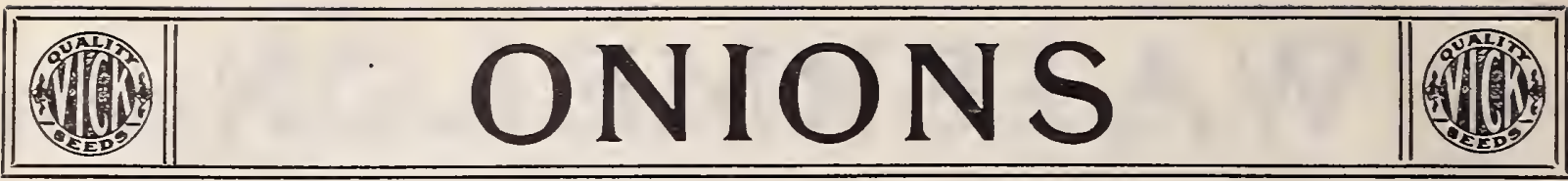

NIONS must have a clean and very rich soil, as it is useless to attempt to grow them on poor ground. A liberal use of manure is more essential to this than to any other crop. Sow in drills not less than a foot apart nor more than half an inch deep, keeping the soil mellow and clear of weeds. One ounce will sow Ioo feet of drill, or 5 pounds per acre.

Special prices to commercial growers will be quoted on application.

\section{Vick's Own Selected Strain Danvers Yellow Globe}

Successful onion growers use this strain in preference to all others. The seed is Northern grown, therefore adapted to growing in any section or climate. This variety is the standard in the eastem markets both for local use and shipping. It produces bullss of usable size early in the season, so that it is a profitable variety all summer. The globe shape and the brownish-yellow skin make it attractive in appearance at all times. It is an extremely hard and solid variety. The bulbs average fully six inches in circumference; the flesh is pure white, crisp and tender, while the flavor is sweet and mild. It is a sure cropper, which fact combined with its other characteristics makes it one of the best and most popular sorts, both for home use and for market.

Packet, 5 cents; oz., 20 cents ; $1 / 41$ 1b, 40 cents; 1 , $\$ 1.50$.

\section{Southport White Globe}

Handsome, large-sized, globular in form. Skin and flesh a pure white. To acceed in producing good pure white Onions, the crop should he pulled just as the stalks begin to fall down, and then allow them to dry off in the open air, keeping them free from rain or dew, which would cause discoloration of the bulbs.

Packet, 5 cents; oz., 25 cents; $1 / 4$ lb., 75 cents; lb., \$2.50.

\section{Southport Red Globe}

Our strain is unsurpassed; it is used for growing the exceedingly fine large bulbs seen in the New York markets. Its beautiful form makes it extremely desirable. It produces large crops on favorable soils, and is a good keeper. Packet, 5 cents ; oz., 20 cents; $1 / 4$ lb., 60 cents ; 1 b., $\$ 2.00$.

Southport Yellow. Globe. It is entirely distinct from the Danvers type, being somewhat more pointed at each end. The fesb is white and mild in flavor. It is quite productive and a good keeper. These onions aiway's command a higb prire in the markets.

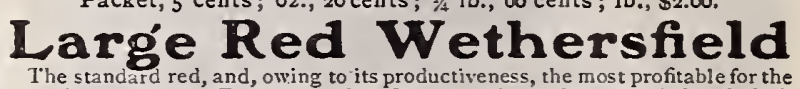
The standard red, and, owing to its productiveness, the most profitable for the
market gardener. Form somewhat fattened, skin a deep purplish red, flesh purplish white. The best variety for poor or dry soils.

Packet, 5 cents; oz., 20 cents; $1 / 4$ lb., 60 cents ; lb., $\$ 1.90$.

Mammoth Prize T aker. Genuine seed of this variety produces handsome, large, Iellow Globe Unions. We bave the seed specially grown for us. Our Americ an Growen Seed produces bulos enormous insize, and the yield per acre is larger than that of any other variety. While not so good a keeper as our Fellow Uanvers, it is a valuable sort for immediate or early fall use. The skin is of a rich yellow straw - color: flesh wbite, sweet, mild, and tender. Packet, 5 cts.; oz., 20 cts.; $1 / 416 ., 50 \mathrm{cts.;} \mathrm{1b.,} \mathrm{\$ 1.75.}$

Large Yellow Dutch or Strasburg. This variety is one of the old standard sorts. It is flat, white-fleshed, fine grained and mild. It is exceedingly productive and a good keeper. A popular sort for growing sets, the product being a round, bright, smooth set.

Packet, 5 cents; 0z., 20 cents ; $1 / 4$ lb., 60 cents ; lb., $\$ 1.90$.

Australian Brown. Distinct from all other Onions; uniform in size and shape; wonderfully hard and solid, and will keep almost indefinitely. Ripens extremely early. It is of medium size, round, with skin of a deep amber-brown; fiesh mild and agreeable.

Packet, 5 cents; oz., 20 cents; $1 / 4$ lb., 60 cents; 1 b., $\$ 2.00$.

Extra Early Flat Red. The earliest of the red sorts, coming into use from ten days to two weeks earlier than the Red Wethersfield. It is adapted to cold, damp, mucky soils, where other varieties fall to produce large-sized Onions. Packet, 5 cents; $0 z ., 20$ cents; $1 / 4$ lb., 60 cents; 1 b., $\$ 2 . \infty 0$.

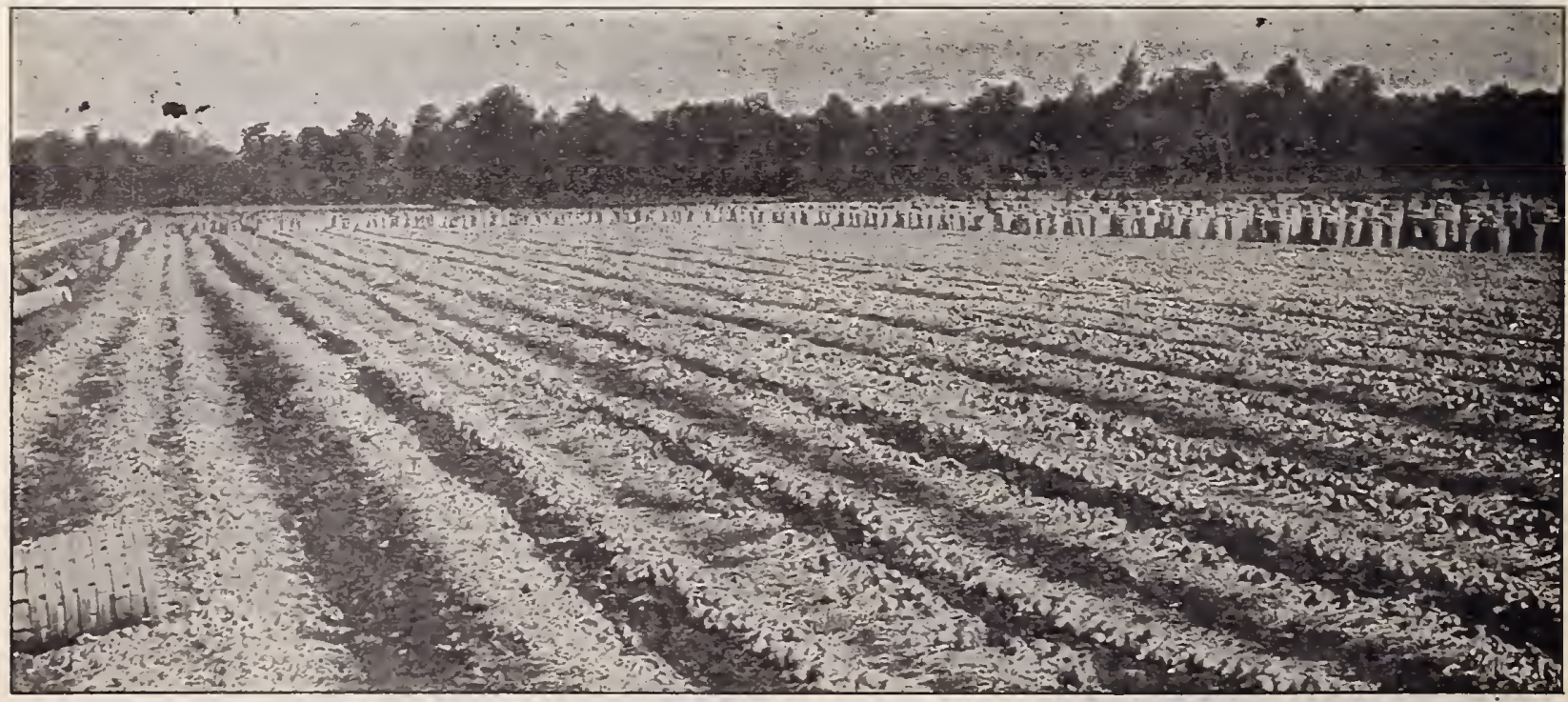

151/2 Acres Vick's Selected Strain of Danvers Yellow Globe Onions. Yield 14,000 Bushels. Grown from our seed at Conewango, N. Y. 


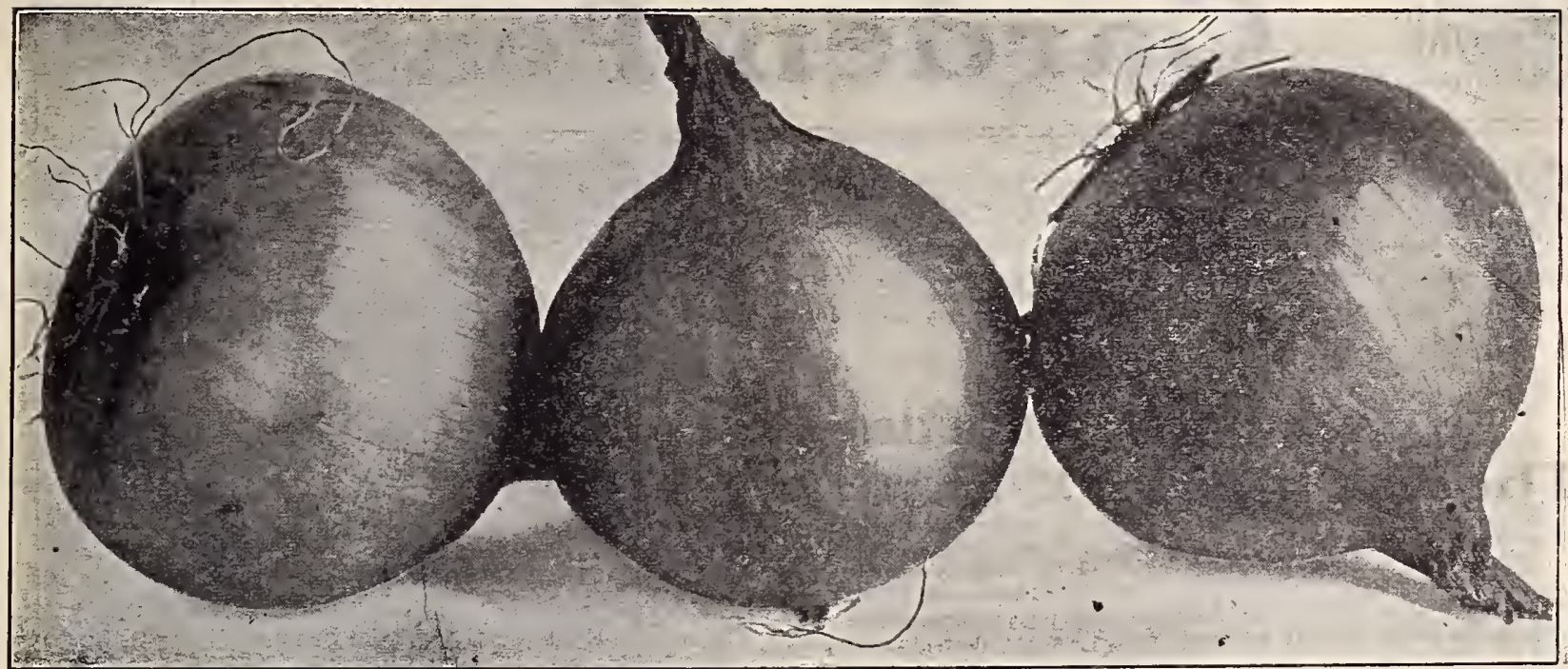

\section{SOUTHPORT WHITE GLOBE}

Ailsa Craig. For home use as well as exhibition purpeses, Ailsa Craig combines all the necessary qualities for the ideal Onion. The skin is pale yellow, flesh snow-white, delicious in flavor; in fact, equal in every respect to the popular Spanish Onions. Under favorable conditions it will grow to an immense size. Requires a long season and the seed should be sown inside and the Onions transplanted to rich soil when the tops are the size of quills. Plan to plant at least a packet this spring; more if you have room. Packet, sufficient to sow 25 feet, ro cts.; 1/2 oz., 25 cts.; oz., 40 cts.;. 1/7 lb., \$1.25; 1b., \$4.00.

White Portugal or American Silver Skin. A large flat white Onion of exceedingly mild flavor. It is a popular sort, and when young excellent for bunching or for pickles. It is also especially adapted for growing sets. Packet, 5 cents; oz., 25 cents ; $1 / 4$ lb., 75 cents ; lb., $\$ 2.50$.

\section{ITALIAN ONIONS}

The flavor of the Italian sorts is mild and well adapted for all culinary purposes. Seed should be sown thicker than that of the American sorts.

Mammoth White Garganus or Silver King. This is mammoth in size, the largest onion in cultivation. The bulbs are very attractive in form, fine-shaped, flattened but thick, with a silvery white skin. The flesh is snow-white, fine-gtained, exceedingly mild, and of pleasant flaror. It matures quite early.

Packet, 5 cents ; oz., 20 cents ; 1/4 lb, 6o cents; $1 \mathrm{~b} ., \$ 2.00$.

Large White Flat Italian Tripol. A handsome, large, pure snowwhite, flat Onion, mild and of excellent flavor. If seed is sown early in hothed and transplanted, it grows to a large-size.

Packet, 5 cents ; oz.,20 cents ; $91 / 4$ lb., $5^{\circ}$ cents; 1 b., $\$ \mathrm{r} .75$.

Large Blood Red Italian Tripoli. Same as preceding, except in color, which is a bright dark red. Used in the South when the Bermuda sorts cannot be had. Packet, 5 cents ; oz., 20 cents; $1 / 4$ lb., 50 cents; 1 b. , $\$ 1.75$.

Giant Rocca of Naples. A very large-growing, globe-shaped variety. The skin is reddish brown in color, flesh very mild and sweet-flavored. Packet, 5 cents ; oz., 20 cents ; $1 / 4$ lb., 50 cents ; 1b., $\$ 1.75$.

White Queen or Extra Early Barletta. This is an extra early, very sinall, round, hard, and handsome variety. The color is a beautiful waxy white; flavor unild and delicate. It is the Onion used in all famous pickle factories in our own country. A favorite for the home garden, as bulbs grown from seed will mature as early as those raised from the ordinary Onion sets. 'The best variety for pickling.

Packet, 5 cents ; oz., 20 cents ; 1/4 lb., 60 cents ; 1b., \$2.00.

White Bermuda (Teneriffe grown). The Bermudas are the earliest Onions in the market, and are grown extensively in the South. Outer skin straw color, flesh pure white.

Packet, 5 cents; oz., 30 cents ; $1 / 4$ 1b., 85 cents; 1b., \$2.75.

Red Bermuda. Similar to the white, but with red skin Packet, 5 cents ; oz., 25 cents; $1 / 4$ lb., 75 cents; $1 \mathrm{~b}$., $\$ 2.50$.

\section{EGYPTIAN or TOP ONION SETS (Perennial)}

The young sets of these are produced on top of the stalks. As they cannot be kept out of ground over winter they must be planted in the fall; therefore, orders for them should be given in the spring for delivery next automn. When once set out, they will come up year after year as soon as frost is ower. They need no protection, grow rapidly, and are very productive.

Quart, 30 cents ; peck, 75 cents ; bushel, $\$ 2.50$. At quart prices we prepay postage. Bushel and peck deliveced at freight or express office, Rochester.

\section{ONION SETS}

Onion sets should be planted as early as the ground is in condition to work , in rows 12 to 15 inches apart, with sets two inches apart in the rows. Green Onions for bunching come in very early, while the crop of large bulbs matures very much earlier than if planted from seed.

True English Multipliers or Potato Onion. Quart, 30 cents; peck, \$1.25; bushel, \$4.00.

Yellow Bottom Sets. Quart, 30 cents ; peck, \$1.25; bushel, $\$ 4-\infty$. White Bottom Sets. Quart, 30 cents; peck, $\$ 1.50$; bushe $1, \$ 4.50$. At quart prices we prepay postage. Bushel and peck deliveredi at: freight or express office, Rochester.

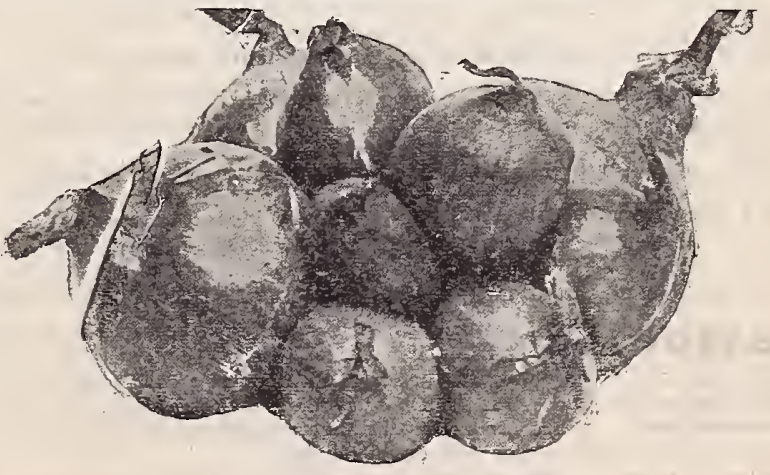

TRUE ENGLISH MULTIPLIERS 


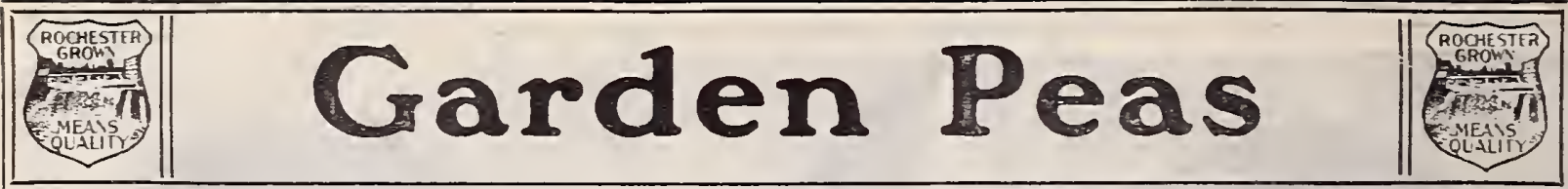

Cow Peas in drills about four inches deep. The drills must not be nearer $\checkmark$ than two feet, except for the lowest sorts. Those growing three feet high or more should not be nearer than three or four feet, and should have brush for their support. Avoid fresh manure and very rich soil, as they cause the vines to grow too rank. One pint will sow forty feet of drill; two bushels for an acre, in drills tliree feet apart.

\section{Extra Early Varieties}

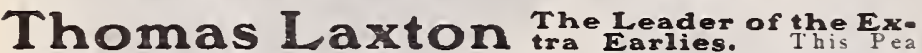

outrauks all other extra early wrinkled varieties in hardiness and productiveness. It has all the delicious sucetness of the Gracius; the pods are large and shapely, of a rich, dark green color, and filled from end to end with seven or eight very large whiteseeded, wrinkled sugar peas, the flavor of which is unsurpassed by any other Pea in cultivation. Vines are strong and hardy and from three to three and one-half feet high.

Packet, ro cents; $1 / 2$ pint, 20 cents ; pint, 35 cents ; quart, 60 cents.

Alaska. A smooth blue Pea, the earliest of all the extra early varieties; good flavor: pods dark green, well filled and ripen uniformly. One of the very best for marketgar deners. Fines two and one-half feet high.

Packet, 10 cents; $1 / 2$ pint, 20 cents ; pint, 30 cents ; quart, 50 cents.

Vick's Selected Extra Early. A Specially Selected Strain. 'The earliest of the early white Peas; unsurpassed either for market or family use; of excellent quality; unusually productive for so early a variety. Vines two and one-half feet high. Packet, Io cents; 1/2 pint, 20 cents; pint, 30 cents ; quart, 50 cents.

Gradus (Prosperity). As an extra early Pea, the Gradus, being a sugar Pea, is far superior to all smooth varieties, not only in its delicious quality, but also in the size of the peas and of the pods.

Packet, Io cents; $1 / 2$ pint, 20 cents ; pint, 30 cents; quart, 55 cents.

Surprise. One of the earliest wrinkled Peas in the market. Vines grow about two feet high, are vigorous and need no bushing; pods well filled, containing about six or seven peas, which are exceedingly tender, sweet, and fine flavored.

Packet, 10 cents ; $1 / 2$ pint, 20 cents : pint, 30 cents ; quart, 50 cents.

\section{Early Varieties}

Little Marve1. An English variety that has come to who have grown it, to be the best dwarf early on the market. W'hen better known it will supercede all other dwarf early sorts. Its strong points are its tendency to bear large crops, and its high quality. It is fully as early as American Wonder or Nott's Excelsior, vines dwarf, growing abuut fiteen inches in height, heavily set with pods two and one-half to three inches in length, filled will six to seven large, dark green peas Packet, Io cents ; $1 / 2$ pint, 20 cents; pint, 35 cents; quart, 60 cents.

Nott's Excelsior. An extra early dwarf, green, wrinkled sort. The peas are superior in sweetness and quality; the viness larger and more vigorous than American Wonder, and yield one quarter more in shelled peas.

Packet, Io cents; $1 / 2$ pint, 20 cents ; pint, 30 cents; quart, 55 cents.

Bliss' American Wonder. One of the rery best of the early winkled Peas bearing large, well-filled prods. The vines are ten to twelve inches high, and of robust habit. A fine variety for the home garden.

Packet, ro cents; 1/2 pint, 20 cents; pint, 30 cents; quart, 55 cents.

Extra Early Premium Gem. An improved Little Gem, another extra fine dwan Pea. Many consider it equal to either Nott's Excelsior or American Wonder. Vines 12 to 15 inches. Very productive, pods large and Peas of excellent quality. An old favorite. Packet, 10 cents ; / pint, 20 cents ; pint, 30 cents ; quart, 55 cents.

Laxtonian Anew dwarl Pea, having the same high quality as the iuches high and when in bearing are filled with immense dark-green pods containing eight or nine large peas. I $\mathrm{t}$ is but a few day's later than the early sorts, but is classed as a second early. It is so productive, the pods so large and well filled, the quality so good, it is deserving of a place in every home garden.

Packet, ${ }_{5}$ cents; ${ }^{1} 2$ pint, 20 cents, pint, 35 cents; quart, 60 cents.

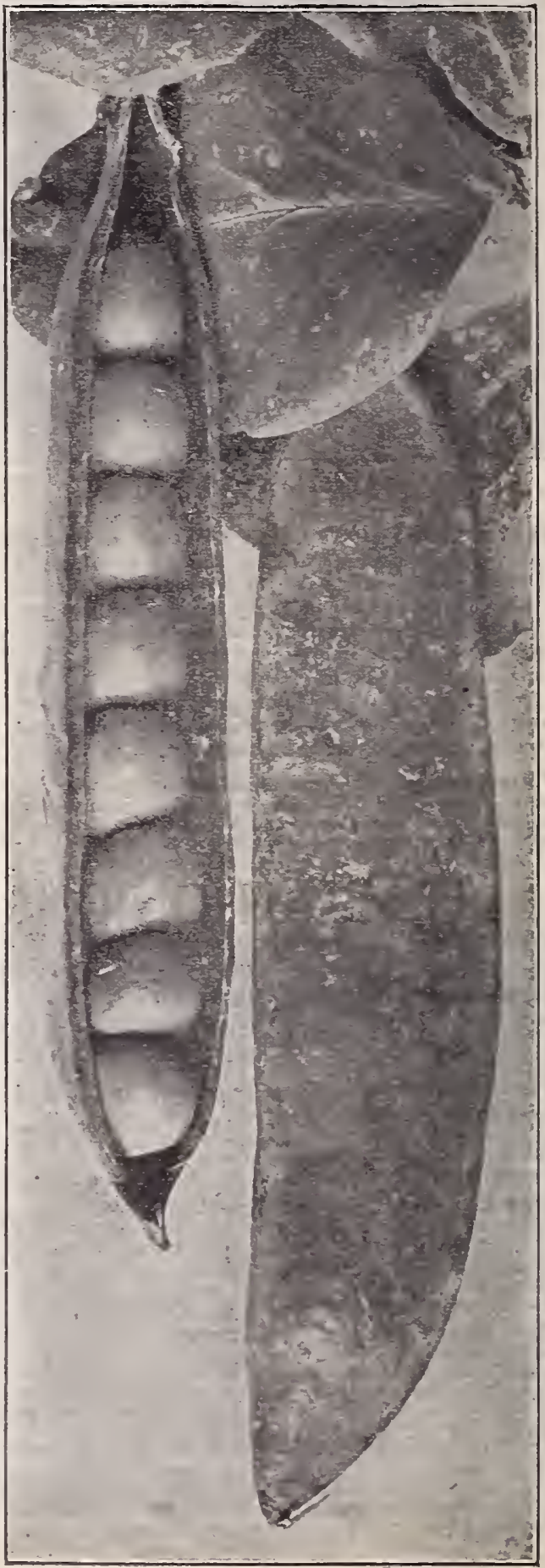

LA.TUNIAN 


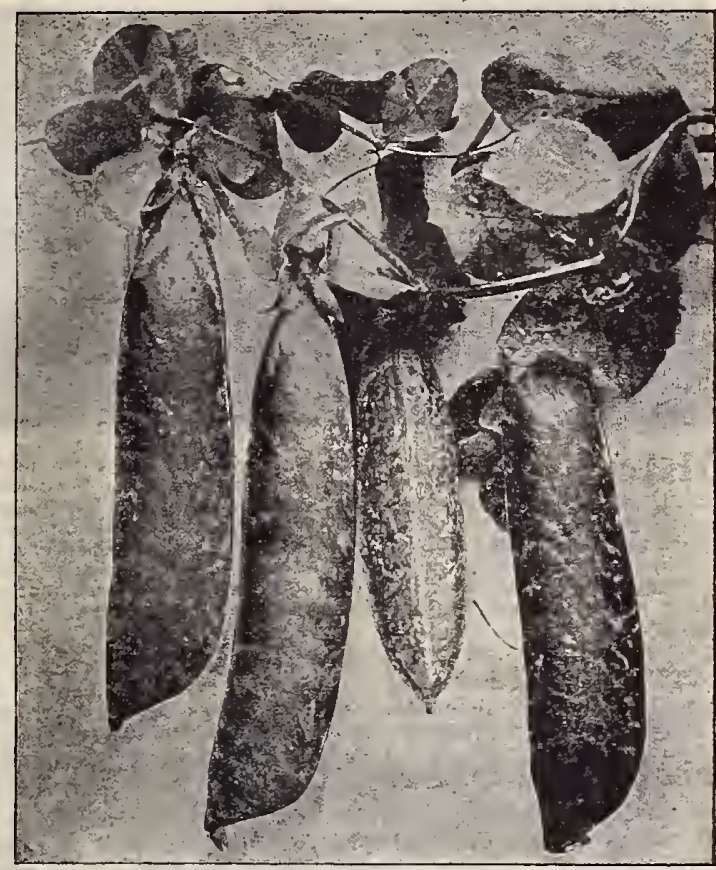

LITTLE MARVEL

\section{Medium Early Varieties}

\section{The Harvester}

See page two for illus. tration. A magnificent new medium early Pea, particularly valuable on account of its enormous yield. In addition to its great productiveness, The Harvester is a very handsome Pea of the highest quality.

Packet, 5 cents ; $1 / 2$ pint, 25 cents; pint, 40 cents.

\section{A d} green pods, well filled with large Peas of crops of large, dark splendid market gardener's variety. Vines four to five feet.

Packet, to cents; $1 / 2$ pt.,20 cents; pt.,30 cents; qt.,55 cents.

\section{Swastika}

"Good Luck" is certainly a wonder. pods five inches long, The plant is branching and covered with Peas almost as sweet as sugar. It is a second early, ready for picking a few days later than the extra early sorts. Vines dwarf, twelve to eighteen inches high, strong and branching, of a brilliant deep green color.

Packet, Io cents; $1 / 2$ pt., 20 cents; pt., 35 cents; qt., 65 cents.

Abundance. Remarkably productive. Plant one and a half to two feet in height; pods three inches long; peas large, wrinkled, of superior quality. Packet, ro cents ; $1 / 2$ pint, 20 cents ; pint, 30 cents ; quart, 55 cents.
Everbearing. A fine wrinkled sort, about thirty inches high; very robust, bearing heavy crops of large, well-filled pods; peas of excellent flavor. Owing to lts branching habit, the peas may be sown thinly.

Packet, 10 cents; $1 / 2$ pint, 20 cents; pint, 30 cents; quart,50 cents.

\section{Vick's Daisy The Daisy is a second early Pea} about two feet in height, bearing an abundanust habit; the vines grow seven to nine large and deliciously flavored peas. It is one of the finest early green wrinkled Marrow Peas in cultivation. Sturdy and branching in habit, requiring no stakes, coming early and remaining late in profitable productiveness, giving green peas of considerable size and of best quality, it is one in the very front rank.

Packet, 10 cents; $1 / 2$ pt., 20 cents ; pt., 35 cents ; qt., 60 cents.

Horsford's Market Garden. A wrinkled variety of superior quality growing two feet high, very stocky; requires no brushing: extremely prolific, bearing pods in pairs. A very desirable sort for canners' use.

Packet, ro cents ; $1 / 2$ pint, 20 cents ; pint, 30 cents ; quart, $5^{\circ}$ cents.

Telephone. A fine, tall, wrinkled variety, and a great cropper, bearing immense pods of large peas of exquisite flavor. It is decidedly a market garden Pea, filling a basket quicker than any other variety. Vines four feet. Packet, ro cents; $1 / 2$ pint, 20 cents; pint, 30 cents; quart, 50 cents.

Long Island Mammoth. One of the most productive Peas in the list. Pods large and handsome, and well filled with peas of excellent flavor. This is another one of those popular sorts for the market gardener, as the large pods soon fill a basket, requiring but little time for gathering the crop.
Packet, 10 cents ; $1 / 2$ pint, 20 cents ; pint, 30 cents ; quart, 55 cents.

\section{Late or Main Crop Varieties}

\section{Admiral Dewey A fine main crop variety Very} and large sugar Peas. Vines about three and one-hali feet.

Packet, to cents ; $1 / 2$ pint, 20 cents ; pint, 30 cents ; quart, 55 cents.

Improved Stratagem This is one of the best of the large podded sorts; vigorous, productive, and of exceedingly fine quality : a favorite with market gardeners everywhere. Vines two to two and one-half feet.

Packet, so cents ; $1 / 2$ pint, 20 cents ; pint, 30 cents ; quart, 55 cents.

Improved Pride of the Market. A very robust, strong-growing variety, about two feet high, requiring no bushing or support; wonderfully productive; fine in appearance, and quality most excellent. A fine Pea for the kitchen garden or for market use.

Packet, to cents ; $1 \frac{1}{2}$ pint, 20 cents ; pint, 30 cents ; quart, 55 cents.

Yorkshire Hero. A very fine, large, dwarf, wrinkled variety, of extra fine quality and very productive. Vines two and one-half feet high, bearing numbers of large well-filled pods.

Packet, Io cents; $1 / 2$ pint, 20 cents ; pint, 30 cents ; quart, 55 cents.

Champion of England. A handsome variety, popular everywhere. One of the richest and best-flavored green wrinkled Peas. Five feet in height. Packet, to cents ; $1 / 2$ pint, 20 cents; pint, 30 cents ; quart, $5^{\circ}$ cents.

Melting Sugar. This variety is used either shelled or cooked in the pod, like string Beans, and when young is very tender and sweet. It is but little known in this country, while abroad it is considered a great relish. Packet, 15 cents ; $1 / 2$ pint, 20 cents ; pint, 35 cents ; quart 60 cents.

Large Black - Eyed Marrowfat. Well-filled pods. Four feet tall. $1 / 2$ pint, 15 cents: pint, 25 cents ; qt., 40 cents.

Large White Marrowfat. Like the Black-Eyed Marrowfat, extensively grown as a field crop. $1 / 2$ pt., 15 cents; pt., 25 cents; qt., 40 cents.

Canada Field. Peck, \$1.00; bushel, \$3.50. Charges not prepaid. Subject to market change.

\section{Peas in larger quantities, by express or freight, not prepaid.}

Alaska (Earliest oא All)

Adniral Dewey

Alderman

American Wonder

Bliss', Abundance .

Bliss' Everbearing .

Champion of England

Extra Early Premium
Gradus (Prosperity).

\begin{tabular}{lllll} 
Qt. & 4 & qts. & \multicolumn{2}{c}{ Peck } \\
35 & I & 25 & 2 & 25 \\
40 & 1 & 35 & 2 & 50 \\
40 & I & 35 & 2 & 50 \\
40 & 1 & 35 & 2 & 50 \\
35 & 1 & 25 & 2 & 25 \\
35 & 1 & 25 & 2 & 25 \\
35 & 1 & 25 & 2 & 25 \\
40 & 1 & 35 & 2 & 50 \\
40 & 1 & 35 & 2 & 50
\end{tabular}

$$
\begin{gathered}
\text { Qt. } \\
35 \\
40 \\
40 \\
25 \\
25 \\
45 \\
45 \\
40 \\
35
\end{gathered}
$$

Qt. 4 qts. Peck

$\begin{array}{llll}1 & 25 & 2 & 25\end{array}$

I $35 \quad 2 \quad 50$

$\begin{array}{llllll}40 & 1 & 35 & 2 & 50 \\ 25 & 90 & 1 & 5 \\ 2 & 90 & 0\end{array}$

90 I 50

$\begin{array}{lllll}45 & \text { I } 50 & 2 & 75\end{array}$

$\begin{array}{lllll}45 & 1 & 50 & 2 & 75\end{array}$

$\begin{array}{lllll}40 & 1 & 35 & 2 & 50\end{array}$

I 25225

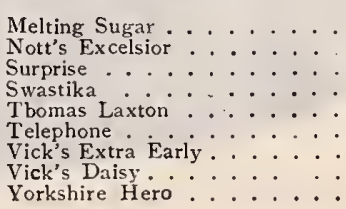

Qt, 4 4ts. Peck

45 I $50 \quad 275$

to I $35=50$

$\begin{array}{lllll}35 & 1 & 25 & 2 & 25\end{array}$

50 I $75 \quad 300$

$\begin{array}{lllll}45 & 1 & 50 & 2 & 75\end{array}$

$\begin{array}{lllll}35 & 1 & 25 & 2 & 25\end{array}$

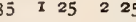

$\begin{array}{llll}45 & \text { I } 50 & 2 & 75\end{array}$

$\begin{array}{llll}35 & 125 & 225\end{array}$ 


\section{SEED POTATOES}

Owing to the increase in the price of Barrels and Boxes we have decided to ship Potatoes in extra strong sacks and allow our customers the difference in the cost. The package will be strong and secure. Those who prefer Barrels, add 40 cents for each Barrel, and $I_{5}$ cents for each Bushel Box.

We always ship Potatoes and other heavy goods by Freight, excepting when ordered sent by Express, or when the quantity is such that to send by Express is cheaper.

Many people order small quantities, like a peck, to go by freight, thinking the charges will be less. This is seldom the case as the railroad companies make no rate for less than 100 pounds; therefore the freight on a bushel is just as cheap as on a peck. Packed for shipment, in boxes or barrels, Potatoes weigh about as follows: Peck, 20 pounds; half bushel, 40 pounds; bushel, -o pounds; barrel, I 85 pounds. A barrel or sack contains $23 / 4$ bushels, I 65 pounds of Potatoes. Please state whether you want the potatoes by freight or express, and do not fail to name the station to which they are to be sent. These prices subject to market change.

\section{Early Varieties}

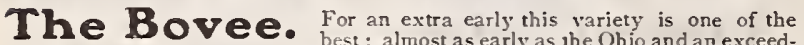
ingly heary yielder for an early. Potato. as early as the Ohio and an exceedand fine quality. In color it resembles tbe Hebron or Rose class. It grows to a good size, oval in shape. An excellent variety. Pound, 25 cents; three lbs., 60 cents; by mail or express, prepaid. Peck, 75 cents; bushel, $\$ 2.00$; sack, $\$ 5.00$; by express or freight, not frepaid.

Early Karvest. One of the best early White Potatoes coupled with large yield, superb quality, and fine appearance, makes a most valuable sort for early marketing or home use. The tubers average large, are nearly white, with eyes only slightly indented; shape oval, flattened, sometimes long-oval. Pound, 25 cents; three lbs., 60 cents; by mail or express, prepaid. Peck, 75 cents; bushel, $\$ 2.00$; sack, $\$ 5.00$; by freight or express, not prepaid.

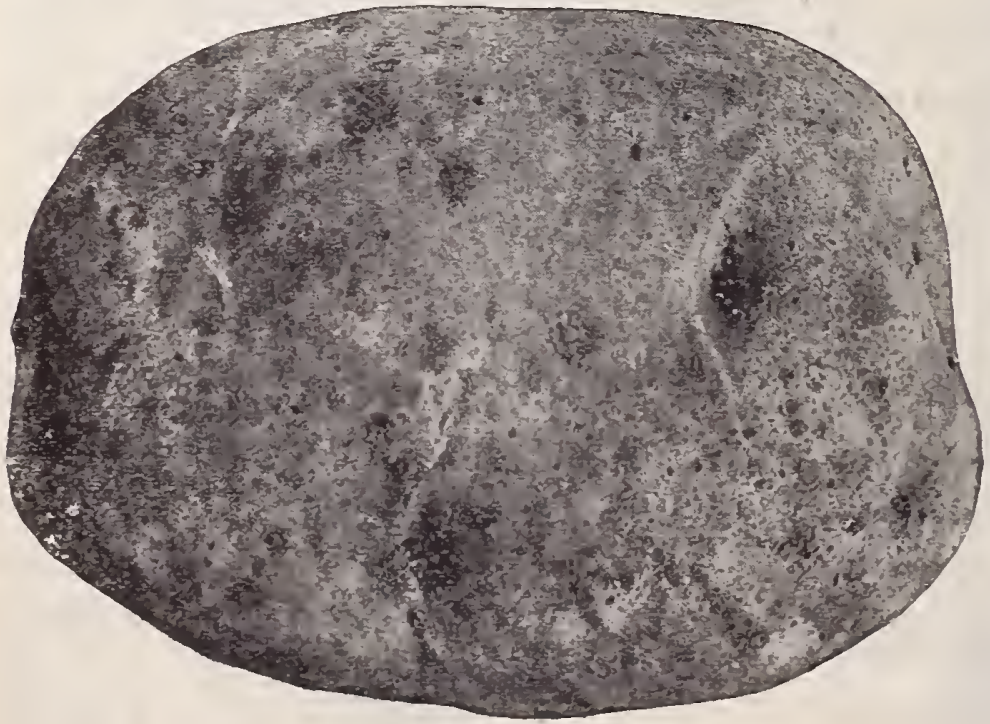

VICK'S LATE VICTUR

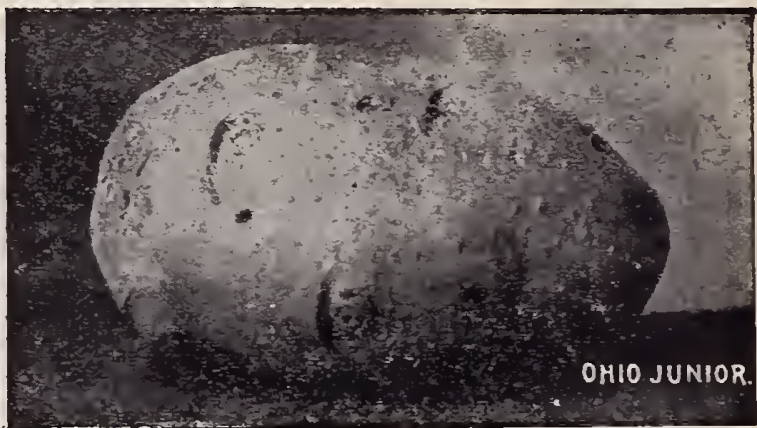

Ohio Tunior. This variety, while not of recent introduc(the earliest Potatoes cuitioblong-oval, round at the seed end, with full eyes that are almost even with the surface. An excellent keeper, very productive, of fine quality, and has proved to be a mosivaluable acdition to our list of exıra early varieties. Pound, 25 cents; three lbs., 60 cents; by mail or express, prepaid. Peck, 75 cents ; bushel, $\$ 2.00$; sack, $\$ 5.00$; by express or freight, not prepaid.

Early Rose. An old favorite early. One of the best for pounds, 60 cents ; mail or express, prepaid. Peck, 75 cents bushel, $\$ 2.00$; sack, $\$ 5.00$ by express or freight, not prepaid.

Irish Cobbler. An extra early, white, round Potato. fine cooking quality and one of the very best early sorts.

Pound, 25 cents ; three pounds, 60 cents; by mail or express, prepaid. Peck, 75 cents; bushel, $\$ 2.00$; sack, $\$ 5.00$; by express or freight, not prepaid.

We can supply seed stock of all the leading varieties.

\section{Late Varieties}

\section{Vick's Late Victor. Catalogued in $x$ gry for the} shape uniform; tubers sound and of excellent cooking quality. This new sort is very productive, vines large and branching, and a large number of fine, sound tubers of just the right size and shape, in each hill. We are pleased to recommend this new variety to all of our customers.

Pound, 25 cents; three pounds, 60 cents: lyy mail or express prepaid. Peck, 75 cents; bushel, \$2.co; sack, \$5.00; by express or freight, not prepaid.

Carmen Seedling. A laie round crop variety vergellent cooking quality. It is fresh from the seed ball, and produces nnusually well. This rariety we consider one of the best main crop potatoes we have ever grown.

Pound, 25 cents; three pounds, 60 cents; by mail or express : prepaid. Peck, 75 cents ; bushel, $\$ 2.00$ : sack, $\$ 5.00$ by express or freight, not prepaid.

Sir Walter Raleigh. This seedling $\mathrm{No}, 2$ is a grand main crop variety. It is an extremely heavy vielder of handsome while skinned, fine grained, smooth. oval potatoes. Pound. 25 cents; three lbs., 60 cents; by mail or express, prepaid. Peck, 60 cents; bushel, $\$ 1.85$; sack, $\$ 4.50$; by express or freight, not prepaid.

Magígie Murphy. The Maggie Murphy tato growers to be one of the best Late Rose varieties, and if planted on light soil the quality is unsurpassed, the yicld enormous. This Potato is oval in form, the skin a delicate pinkish tint, with russet markings, eyes flish wish the surface. Plants very strong and vigorous, remaining green up to maturity. Pound, 25 cents : three lbs. 60 cents; by mail or express, prepaid. Peck, 75 cents; bushel, $\$ 2.00$; sack, $\$ 5.00$; by express or freight, not prepaid.

Improved Green Mountain. Une of the best general crop varieties; round, a12. white, large tops. Does well in all lncalities and yields large crops. Pound, 25 cents; three pounds, 60 cents; by mail or express, prepaid. Peck, 75 cents; bushel, $\$ 2.00$ : sack, $\$ 5.00$; by express or freight, not prepaid. 


\section{PARSLEY}

Parsley seed germinates very slowly. For outdoor growing, soak the seed in hot water for twenty-four hours. Sow thickly, in rows one foot apart and half an inch deep, pressing down well after sowing. When well up, thin to six inches apart. Parsley lives through the winter, and seed may be sown in the autumn. One ounce will sow 150 feet of drill.

Packet, 5 cents ; oz., ro cents ; $1 / 4$ lb., 25 cents ; 1b., 85 cents; except as noted.

Exquisite Moss Curled. A new variety of gxeat merit. Rich dark green finely cut and crimped. Packet, 10 cents.

Champion Moss Curled. A compact growing, very ornamental plant Leaves a bright green color, finely crimped and beautifully curied.

Vick's Triple Curled. A handsome compact sort. Fine for market or private garden; leaves iright pale green; extra curled and crimped.

Beauty of the Parterre, or True Emerald. A distinct shade of green; leaves finely cut and densely curled. Dwarf and spreading.

Packet, 5 cents; oz., Io cents ; $1 / 4$ lb., 30 cents ; lb., \$1.00.

Fern-Leaved. Beautiful in form and color; valuable for garnishing, and also as an ornamental foliage plant for borders of beds.

Packet, 5 cents; oz., 15 cents ; 1// lb., 35 cents; lb., \$1.25.

Hamburgh or Turnip-Rooted. The roots resemble a small Parsnip, and are the edible portion of this variety. Used for flavoring soups, etc.

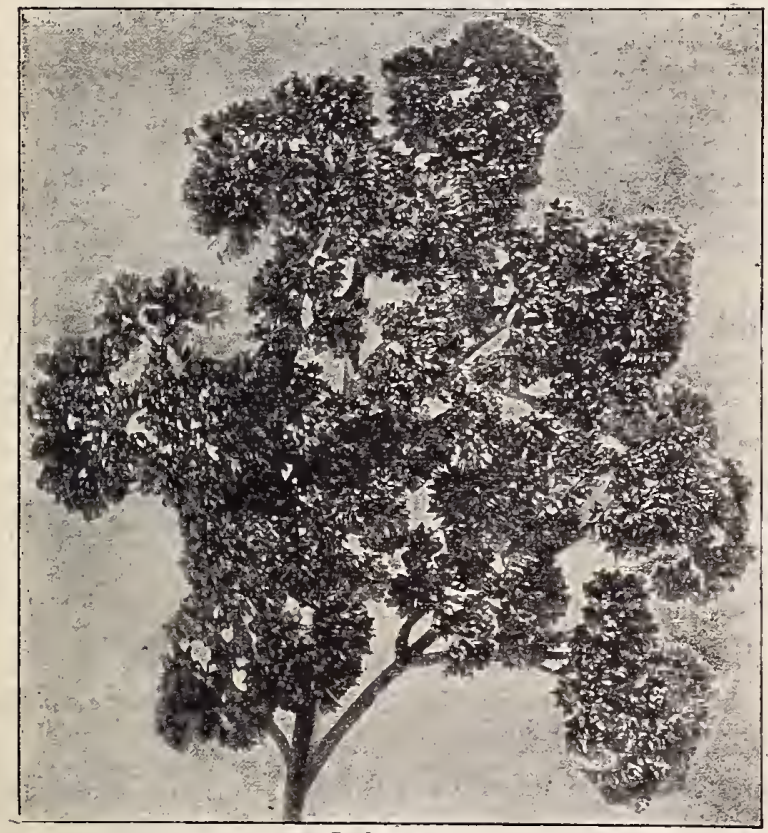

PARSLEY

\section{PARSNIP}

Parsnip seed germinates very slowly, and does best in a cool, moist soil; therefore it should be suwn as early as possible, in drills from fifteen to eighteen inches apart, and about half an inch deep. One ounce will sow 200 feet of drill.

Elcombe's Giant. A new Parsnip having all the good qualities of Hollow Crown hut smoother, not quite so long and much thicker at the shoulder.

Packet, 5 cents ; oz., 10 cents ; $1 / 4$ 1b., 25 cents ; 1b., 75 cents.

Long Hollow Crown (White Dutch or Sugar). The old standard, and one of the best for general use. Long, smooth, tender, and sugary; very hardy.

Packet, 5 cents; $0 z$. , Io cents ; $1 / 4$ lb., cents ; $1 b ., 75$ cents.

Improved Guernsey. Half-long. The roots are larger in diameter and easily gathered: smooth, fine-grained, and of excellent quality.

Packet, 5 cents; oz., to cents; $1 / 4 \mathrm{lb}, 25$ cents ; pound, go cents.

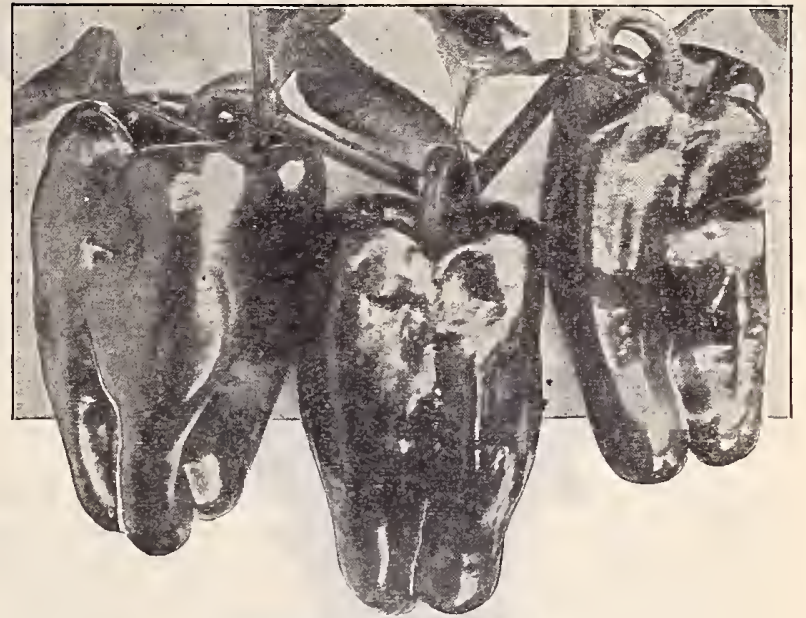

PEPPER, VICK'S GIANT RED

\section{PEPPER}

Sow seeds in a hotbed, or in a box in the house, where a temperatnre of 75 degrees can be maintained. Transplant when three inches high. Une ounce of seed will yield about $\mathbf{r}, 500$ plants.

Packet, 5 cents ; oz., 25 cents; 1/4 1b., 75 cents; 1b., \$2.50; except where noted.

Vick's Giant Red. A magnificent new variety. Combines the size, mildness and beauty of the Chinese Giant with great productiveness. Packet, xo cents; $1 / 4$ ounce, 20 cents ; $1 / 2$ ounce, 30 cents; ounce, 50 cents; $1 / 4$ pound, $\$ 1.50$; pound, $\$ 5,00$.

Chinese Giant. Immense Pepper of a brilliant scarlet color. The flesh is unusually thick and very mild, having none of the pungency of most of the older varieties. The plant is about two feet bigh and of strong vigorous growth. Packet, 10 cents; $1 / 4$ ounce, 15 cents; $1 / 2$ ounce, 25 cents ; ounce, 40 cents; $3 \%$ lb., \$1.15; lb., $\$ 4.00$.

Large Bell, or Bull Nose. Very large, nearly four inches long and three inches in diameter; glossy red. Excellent for use in salads and pickles.

Ruby King. A handsome and very productive variety. Fruit from four to six inches long by three and a half to four inches broad; remarkably mild and pleasant. When ripe they are a bright ruby red.

Golden Dawn or Queen. Resembles the Large Bell in shape, but is more delicate in flavor. Color a rich golden yellow, with very thick, mild, sweet-flavored flesh.

Sweet Mountain or Mammoth. Much like the Large Bell, but larger and milder. Fruit thick and sweet. Fine for making stuffed mango pickles.

Coral Gem Bouquet. The finest of the sma!l varieties. Its shining red pods, an inch in length, are so thickly set as to completely cover the plant. They are very hot, and suitable for seasoning. Makes an elegant pot-plint. Packet, 5 cents ; oz., 50 cents ; $1 / 4$ Ib., $\$ 1.50 ; 1 b ., \$ 5.00$.

Red Cluster. A distinct and beautiful variety, bearing a profusion of bright scarlet fruit in clusters in an upright position. Hot and pungent. As a decorative plant for the flower garden or for pots, it will be found very useful. Packet, 5 cents; $0 z ., 30$ cents; $1 / 4$ lb., 85 cents; lb., $\$ 3.00$.

Celestial. A Chinese variety, useful as well as ornamental. Sets its fruit early, and continues until frost. The upright fruit is first white, then golden yellow, changing, when fully grown to a bright scarlet.

Long Red Cayenne. Beantiful and productive. Fruit four inches long bright red, pointed pod; flesh thick and pungent.

\section{Small Red Chili, Cherry-Formed Red.}




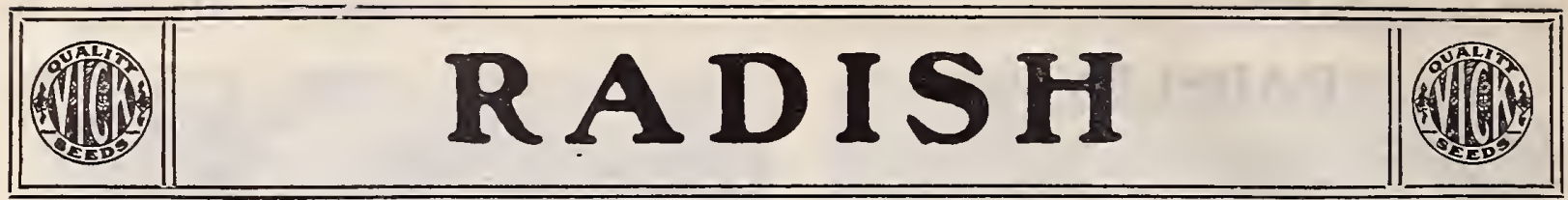

COR early use seed should be sown in the hotbed, in drills, three to four inches apart and half an incli deep. For open ground sow - as weather conditions permit. As soon as the first leaves appear, sprinkle with soot or ashes to save them from the turnip fiy. The Winter Radish should be sown about the middle of the summer, and makes its best growth in autumn. One ounce will sow Ioo feet of drill; ten pounds to the acre.

Packet, 5 cents; ounce, I5 cents; one quarter pound, 25

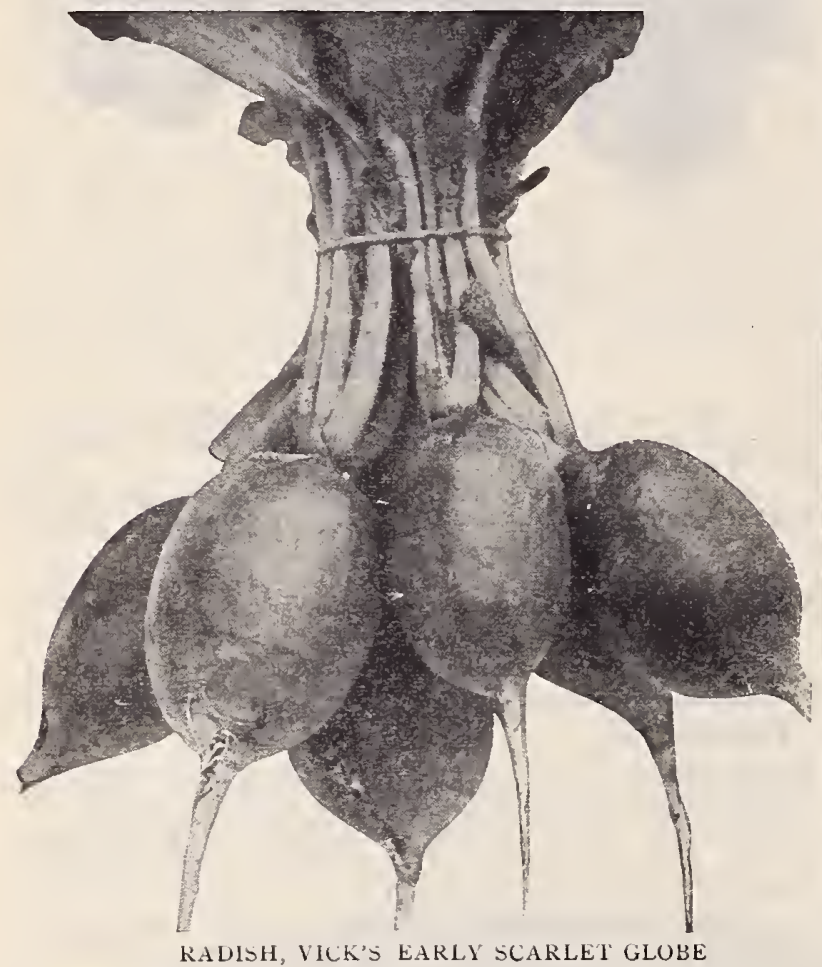

\section{Vick's Early Scarlet Globe} The Best Radish for General Use

It is handsome in both form and color, a beautiful oval and a rich scarlet; the fiesh is crisp, tender, juicy and mild. The amount of its foliage is small compared with other varieties and small for the size of the Radish, making it a particularly attractive market sort. As a forcing Radislı, Vicli's Early Scarlet Globe is the best in every way, bearing the lieat requisite for forcing without becoming pithy or spongy. Away back in $188_{4}$, we introduced this unirersally popular Radihh, and torlay it is sold by almost every seeds. man in the world, and is alio used by the leading market gardenels boll for forcing and out-of-cloor planting. Owing largely to our care in selecting and growing seed, it leads all other varieties.

Vick's Early Scarlet Globe Radlsh is the Best all-round Radish on the market; and is therefore valuable for both the home gardener and the man who grows Radishes for the market. You will find "Vick Quality" in every ounce.

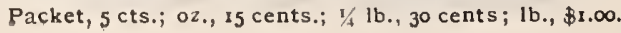

\section{Vick's Three Weeks Radish}

See Illustration on page two.

\section{A New Forcing Radish of Great Value}

Extremely Early. Brilliant Color. Small Top and Tap Root. Uniform Shape. Good Quality.

Vick's Three Weeks Radish can be grown, ready for the table, in less than three weeks from the day of sowing the seed. The root begins 10 develop with the development of the first leaves. This new Radish has a color quite distinctive, a light, fiery scarlet, giving it a very attractive appearance in the market or on the table. Vick's Three Weeks has a small top, even for an early Radish, and a remarkably slender tap root. This is well shown in the illustration, page two. Vich's Three Weeks Radish is pelfectly round and grows to a uniform size in fact it is remarkably uniform both in size and in shape. As a forcing Radish we have found Vick's Three W'eeks all that could be desıred. Solid, crisp and tender. Equally valuable for the garden.

Vick's Three Weeks Radish is entirely distinct from any. Radish heretofore offered. As an all-round Radish we do not think it can displace Vick"s Scarlet Glube; but it has sterlung qualıties of its own that will give it a permanent place in the list of best Rudishes. We urge our cttstomers to give it a trial.

Packet, 15 cents; five packets, 65 cents.

Vick's All Seasons, Good at all times from the size of ns. a marble to as big as a base ball. It may be sown from spring until autumn, and the roots cbtained from late sowing can be kept un storage for winter consumption. It can be used in all stages, from the size of a marble until full grown. The root is round, of brilliant scarlet color, grows to a very large size, and remains firm and brittle to the end. When sliced and salted it makes a very fine relish.

Long Brightest Scarlet The brightest and handsomest long scarlet or Cincinnati Market. Radısh grown. Fit for use in twenty-five good condition until fully grown, when it is as large and crisp as Wood's Early Frame. T'op small.

Vick's Improved Long Scarlet Short-Top. The favorite long marwhere; six or seven inches long. Our strain of this popular sort has beeu grown from a selection year after year until it is perfection itselt.

Beckert's Chartier (Shepherd). A distinct variety. Color red at the top, shading to pink in the middle, and passing into pure white. It attains a large size before becoming unfit tor use.

Long White Vienna or Lary Finger. Beautiful in shape: skin and flesh suow white; crisp and tender in summer.

Icicle. A beautiful transparent white variety, about three inches long and half an inch in diameter, with small tops: very crisp and brittle, and remains in good condition a long time; does not get pithy. Suituble for forcing.

Early Round Dark Red (Non plus ultra). Especially adapter? for forcing on account of its very small tap-roots and top. It is also good for summer use in open gromd. Skin dark red f flesh white, crisp and tender.

Scarlet Turnip White Top (Rosy Gem). Forcing. Very desirable for forcing and outdoor planting. Tops and ronts looth simall; skin bright scarlet; Heslı very muld and crisp.

Extra Early Scarlet Turnip-Rooted. Medium size, witl al small top. Excellent for forcing.

French Breakfast, or Scarlet Olive-shaped White Tip. Very tellder and beautiful. Fine for open ground or forcing.

Triumph. A striking variety. Root globe-shaped, showing briglt scarlet stripes on a white ground.

Other good varieties; Giant White Stuttgart. Yellow Turnip. Philadelphia White Box. Scarlet Turnip. White Turnip, Wood's Early Frame, 


\section{Radishes-continued}

White Delicious. An improvement on the White Strasburg being earlier, more evenly shaped, and baving a smaller top. For outdoor early fall sowing it is sure to make a crop of uniform white Radishes; Quality first class.

White Strasburg Summer or White Hospital. A I a rge white, showy, half-long variety. Matures early. A leading market_wariety.

\section{Cooper's Sparkler A new variey of tinct} tinct type. In shape it is globular: the top is very short, thus making it a rosy carmine, with a long white tip. Cooper's Sparkler will keep longer in good condition than any other variety we have tried, and can be grown the year round. Successive sowings should be made during the sunmer

Packet, 5 cents ; 02 ., Io cents: $1 / 4$ lb., 25 cents; lb., 6o cents.

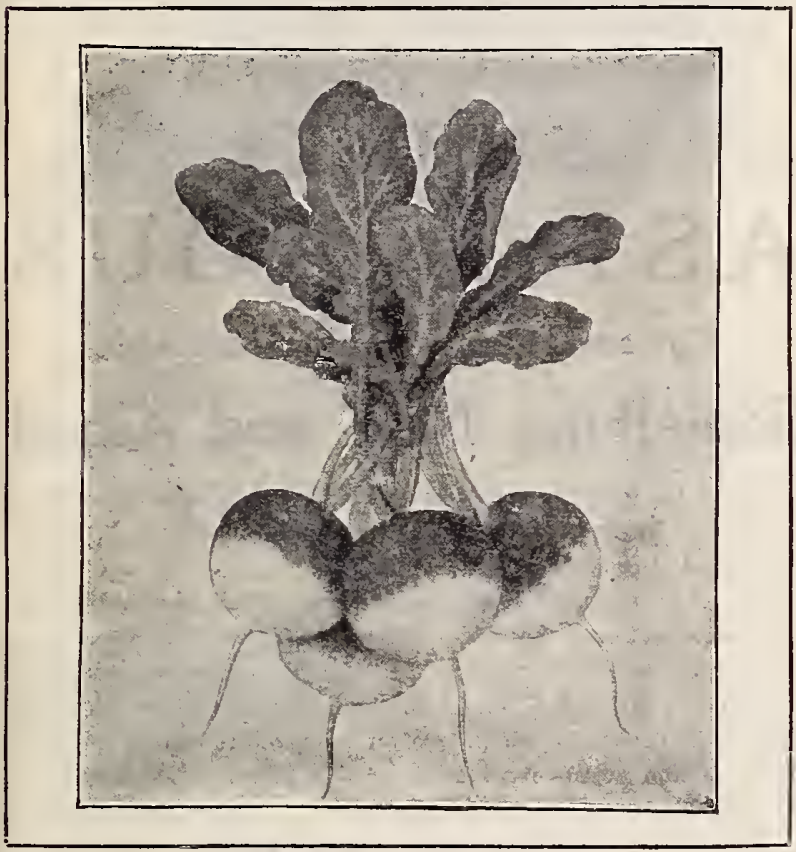

COOPER'S SPARKLER RADISH

\section{Winter Radishes}

Packet, 5 cents; oz, 10 cents ; $1 / 4$ lb., 20 cents ; lb., 60 cts., except as noted; all postpaid.

Chinese Rose Winter (Scarlet Chinese). One of the very hest. Large White Spanish Winter. Long Black Spanish Winter. Round Black Spanish Winter.

California Mammoth White Winter. Eight to twelve inches long and from two to three inches in diameter; white, solid, and of good flavor. The Winter Radishes have a very firm white flesh. Grown to mature in the fall. They may be kept a long time.

\section{RHUBARB}

Sow in drills eighteen inches apart and one inch deep. Thin out the plants to six inches apart. In the fall prepare the permanent bed by trenching two feet deep, mixing a liberal quantity of manure with the soil. Into this set the plants about five feet apart each way. The stalks should not be cut until the second year. One ounce should give about 500 plants

Packet, 5 cents ; Oz., 15 cents ; $1 / 4$ lb., 40 cents; 1 b., $\$ 1.25$. St. Martin's. One of the earliest as well as most prolific Linnæus. Early and tender.

Victoria. Very large, but later than Linnæus.

Roots of above, each, 15 cents; dozen, 1.50.

\section{SPINACH}

Nearly everyone likes succulent green vegetables in early spring. If you have not grown Spinach in your garden heretofore, why not try it this year? "It is the easiest and quickest way to produce a crop of "greens" and we have the best Spinach Seed that money can buy. We handle inmense quantilies of Spinach Seed for a critical market garden and truck farm trade and use only the highest grade of seed, produced by the most expert growers in the world.

For a succession, the seed may be sown early in April and again in May, in drills one foot apart and one inch deep, properly thinning out when plants are an inch in the leaf. For the principal crop, sow from first to niddle of September, protecting the crop with a light covering of straw or leaves. One ounce for too feet of drill; io pounds, in drills, for an acre.

Packet, 5 cents ; oz., ro cents ; 1/4 1b., 15 cents; lb., 40 cents; except as noted.

\section{A Seasons It is a well-known fact that Spinach will} condition longer than any other variety we have grown. The foliage is dark green, crinkled, sweet and luscious. The seed may be sown at intervals during the Summer. An exceptionally fine variety.

Packet, 5 cents ; oz., Io cents ; $1 / 4$ lb., 25 cents ; 1b., 50 cents.

Improved Thick-Leaved, or Long-Standing. Leaves la rge and thick, somewhat crumpled. Does not run to seed as early as most other varieties. Tons of this variety sold to large growers.

Victoria. A valuable sort. Its attractive dark green color, long-standing, and hardy character, make it desirable for both spring and late sowing.

Round or Summer. Adapted tor early spring sowing, and quite popular with market gardeners. Leaves thick and large. It stands the winter well,

Large Round-Leaved Viroflay. Large, round, thick and fleshy leaves. Good for tarly sowing. Quite hardy. Une of the best for fall sowing. Bloomsdale or Savoy-Leaved (Norfolk.) The earliest of all varieties, and one of the best to plant in autumn for early spring use. The leat of this sort is wrinkled in the same manner as the Savoy Cabbage,

Prickly or Fall. A hardy variety, used for fall sowing. With very slight protection it will withstand the severest weather.

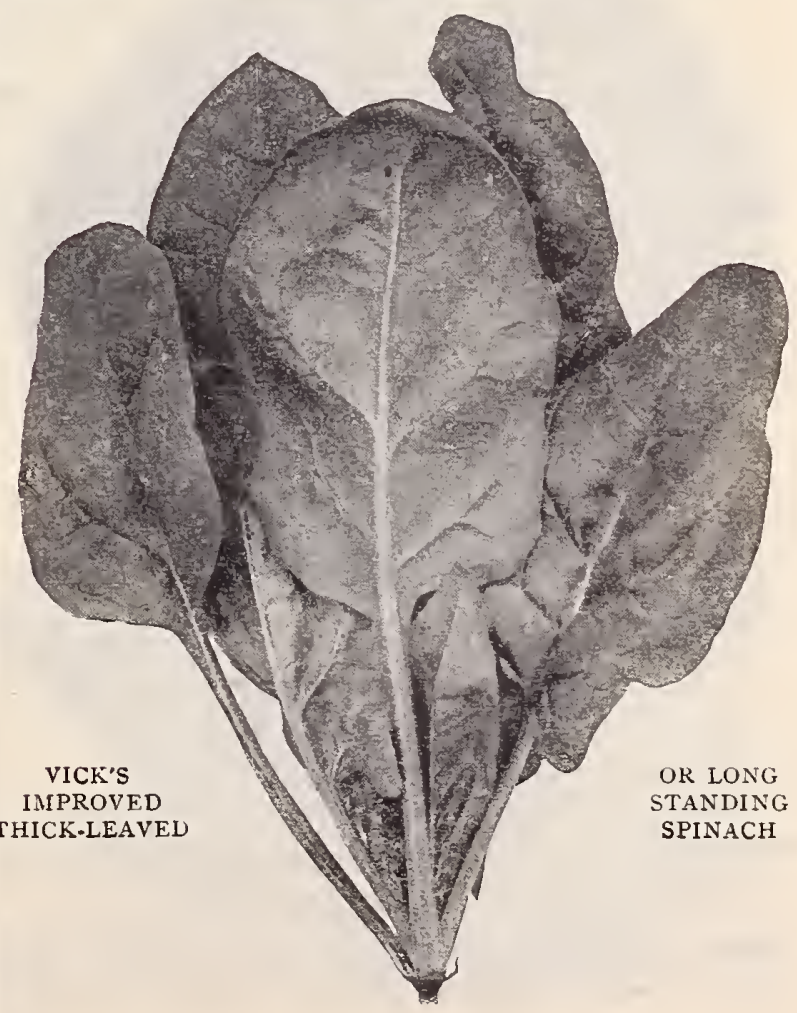




\section{PUMPKIN}

Plant in hills eight feet apart each way, any time after the middle of May. Avoid planting near other vine crops, as they will hybridize and damage the crop. One ounce will plant about twenty-five hills; four pounds to the acre.

Packet, 5 cents; oz., Io cents; $1 / 4$ 1b., 25 cents; 1b., 85 cents; except as noted.

Winter Luxury. A medium-sized pumpkin, of very high quality. It is also a good keeper, wonderfully productive, while its finely netted skin and golden-russet culor make it desirable for market use.

Large Sweet Cheese (Kentucky Field). Very productive. Shape flat: skin mottled light green and yellow, changing to a ricb crimson color; flesh yellow, thick, and tender.

Golden Oblong. A productive variety, oblong in shape, growing 16 to 18 inches long. Skin golden orange, thin and tougl ; almost as good a keeper as the hard-shell winter Squasb. Flesh yellow, dry, and sweet; excellent.

Large Tours, or Mammoth. Grows to an immense size, often weighing over soo lbs.

Mammoth Red Etampes. Skin brilliant, glossy red; flesh deep orange, very thick. Matures early. Packet, ro cents; oz., 20 cents ; I/4 lb., 50 cents; lb., \$r.50.

King of the Mammoths, or Jumbo. The largest of all Punpkins. Round in shape, flattened at both ends. It is a splendid keeper, and valuable for stock feeding; also desirable for exhibition purposes.

Connecticut Field. The hardiest of all Pumpkins; cultivated mainly for stock feeding, producing enormous crops,

Packet, 5 cents ; oz.,10 cents ; $1 / 4$ lb., 15 cents ; Ib., 40 cents.

Cushaw, or Crookneck. A favorite sort of excellent quality.

Packet, 5 cents; oz., Ic cents; $1 / 4$ lb., 30 cents ; lb., $\$ 1.00$.

Sugar, or Pie. The Favorite for Pies. Small, round, handsome deep orange. Flesh fine grained, sweet and dry. Plants very productive.

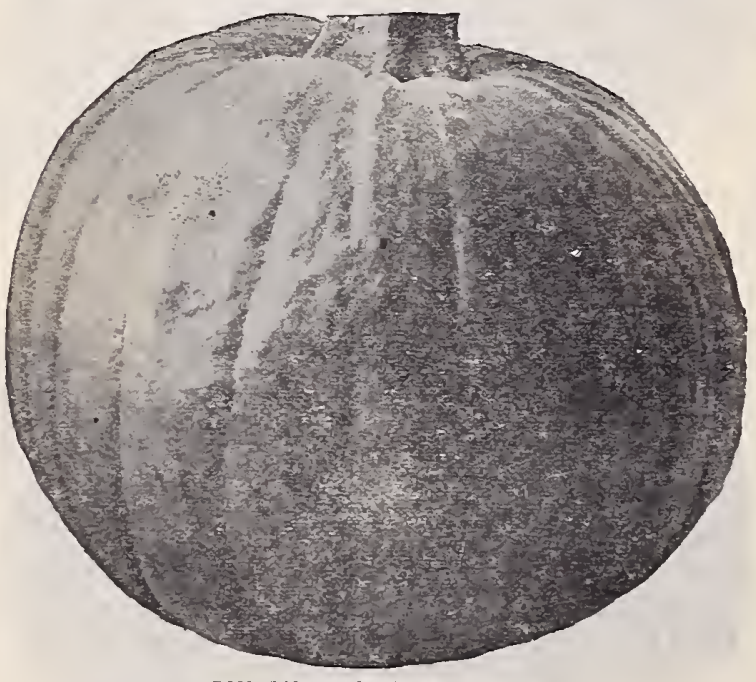

PUMPKIN, SUGAR OR PIE

\section{SALSIFY}

White French. The old favorite variety.

Packet, 5 cents; oz., I5 cents; $1 / 4$ lb., 40 cents ; lb.. $\$ 1.50$

Mammoth Sandwich Island. This is the largest and most profitable Salsify now in cultivation.

Packet, 5 cents; 0z., 15 cents; $1 / 4$ lb.50 cents; lb., $\$ 1.50$.

Spanish Salsify, Scolymus. In flavor the Scolymus is between Salsify and Parsnip. More produclive and lighter color than other varieties of Salsify. Packet, to cents; $0 z_{.}, 20$.cents; $1 / 41 \mathrm{lb}, 85$ cents; lb., $\$ 3.00$.

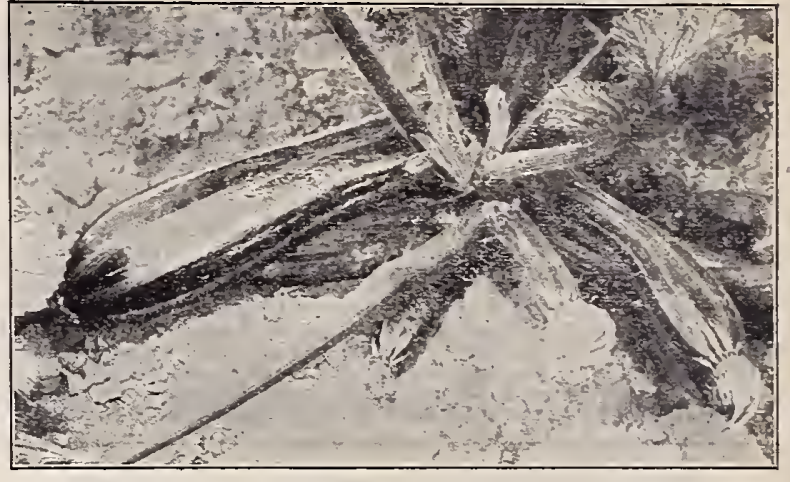

SUMMER ASPARAGUS

\section{SUMMER}

\section{A S PAR A GUS}

Cut and Come Again Vegetable

\section{Something New and Good}

One of the most delectable vegetables that has been introcluced in years. Well worth a place in everyone's garden. All who have tried it pronounce it delicious.

The plant makes a strong growth, very much like that of the Summer Crookneck Squash. The oblong green fruit forms close down in the axils of the leaves. It should be cut when not more than four to six inches long. As the fruit grows larger it loses its delicacy of flavor, and when one fruit is allowed to mature it checks the formation of any more fruit on that plant. Care should be taken in cutting not to injure the plant.

Cooked the same as Asparagus, either whole or cut in simall pieces without peeling. Especially delicious cut in small pieces and cooked with cream. It is also used sliced and fried and as a salad.

Four or five hills is sufficient for a large family, as it may be cut almost every day until frost. Sown early it will fruit from the latter part of June until October. Plant in lills $33 / 2$ to 5 feet apart any time from the latter part of May until July first.

Packet, 15 cents; Ounce, 75 cents.

Fames Vick's Sons, Rochester, N. Y.,

Sfokane, Wis., 11, 3, 13 .

Gentlemen :-Last April I bought of yanr firm some "Summer Asparagus" seed, and I thank you very much for it. It is a great vegetable; the best I ever saw. It is such a prolific producer. I had six plants and I gave many to friends, all of whom praise it highly. Nly father used to buy seed from Fumes lick when you were probably a very small boy.

$$
\begin{aligned}
& \text { Sours ze'y lialy, } \\
& \text { A. F. KENT, } \\
& \text { N. f201 Howard St., Spokane, Wis. }
\end{aligned}
$$




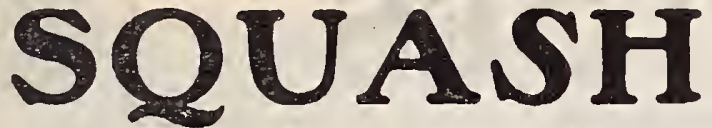

Squash likes a rich soil, and it is best to manure in the hill, using only well rotted manure. Plant a dozen seeds in each hill, and when danger from "bugs" is over cut out all but three or four, being careful not to disturb the remaining plants. For bush sorts, make hills four or five feet apart each way, and for the rumning kinds twice that distance. Winter Squash should be ripened thoroughly, or they will not keep throigh the winter. One ounce of early varicties fur fifty hills and two ounces of late will plant fifty hills; three to four pounds per acre.

Packet, 5 cents; ounce, 15 cents; 1) lb., 40 cents; 1b., $\$ 1.25$.

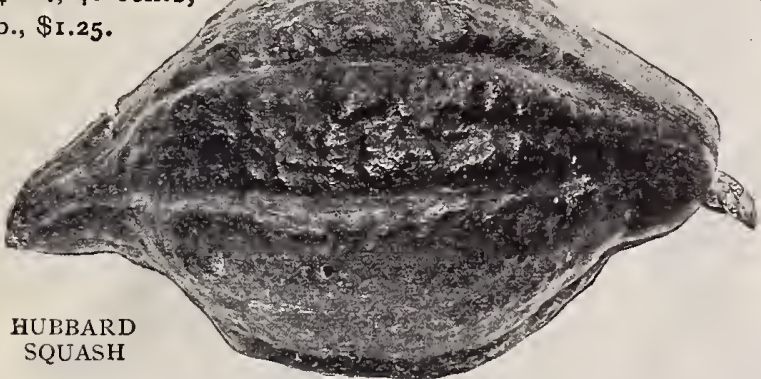

\section{Fall and Winter Squashes}

Delicious. In size it resembles the Hubbard. In thickness of is dark bronze green. For table use no other variety compares with it in its remarkable combillation of fineness and compactness of grain, dryness, sweetness, and exceeding richness of flavor. It is best in the fall and early winter. Specially selected strain.

Packet, ro cents; ounce, 20 cents ; $1 / 4$ pound, 50 cents; pound, $\$ 1.75$.

Early Prolific Orange Marrow. An improvenient by selection fromBoston Marrow; not so large but much earlier. orange- colored; flesh deep, fine grained, and of delicious flavor.

The Golden Bronze. Weight from eight to ten pounds : color, a dark grayish green with bronze on tbe upper surface when ripe : flesh golden yellow, very thick, fine grained. sweet, and of a delicious flavor. Matures early', and is a good yielder and splendid keeper. As a Squash for the table and pies it has no superior.

Hubbard. The standard Winter Squash: no better variety any other. Flesh fine-grained, dry and of excellent flavor.

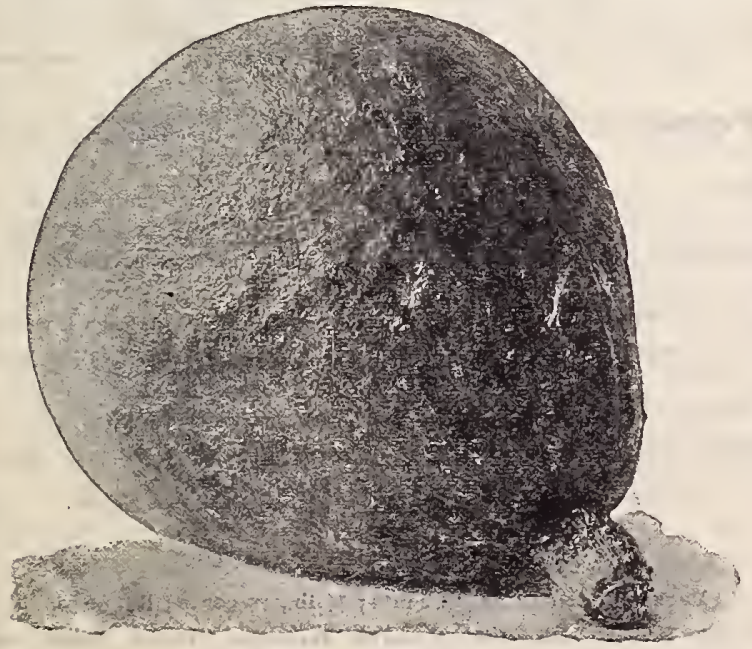

GOLDEN BRONZE SQUASH

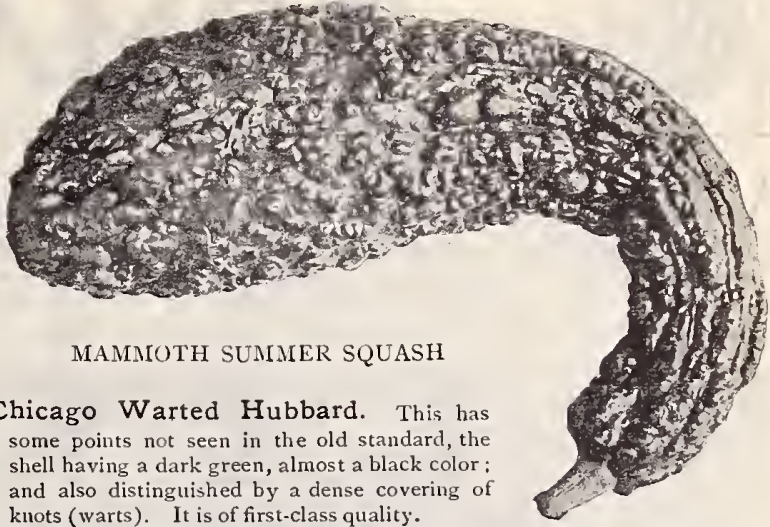

New Golden Hubbard. This is a true Hubbard Squash except in color; which is a bright orange-red. The flesh is deep golden yellow.

Fordhook. A very fine winter variety. Shell a bright yellow; flesh strawyellow, dry and sweet, and of good flavor. Matures early, a sure cropper and very productive. May be used at any stage of growth.

Essex Hybrid or Hard Shell Turban (Warren) A cross between the Hurbbard and American Turban, having the color, shape, and fine quality of the Turban, with the dryness and hard shell of the Hubbard. Flesh thick, fine grained and solid. A good keeper. Very productive, early and of rapid growth.

Sibley, or Pike's Peak. A very distinct and valuable variety. Shell pale green, very hard; flesh solid and thick, orange color; flavor rich and delicate.

Boston Marrow. Very popular in the Boston market. Oval shape: skin yellow; flesh orange-colored and fine-grained.

Mammoth Chili. The largest of all Squash; grows to an enormons size. One of the most profitable sorts for stock feeding. Keeps well throughout the winter. This variety is also extensively grown for fair exhibits.

Vegetable Marrow. Flesh rich, salmon yellow, dry and fine-grained.

Excellent as a pie-squash.

\section{Summer Squashes}

Mammoth Bush Summer Crookneck.

The richest and best of the Summer Squashes. Early and productive. Color golden yellow; flavor sweet and rich. It is almost twice as large as the ordinary Summer Crookneck.

Mammoth White Bush Scallop Silver Custard The best of the scalloped Squasbes. Plant true bush form. Fruit oval to flat. Early and valuable for market or table. Handsome and of fine quality. Delicata. A beautiful small oblong Squash. In color orange is rich, dry and extra fiue quality when cnoked. In season it is very early, maturing the same time as other extra early varieties and used in the same way.

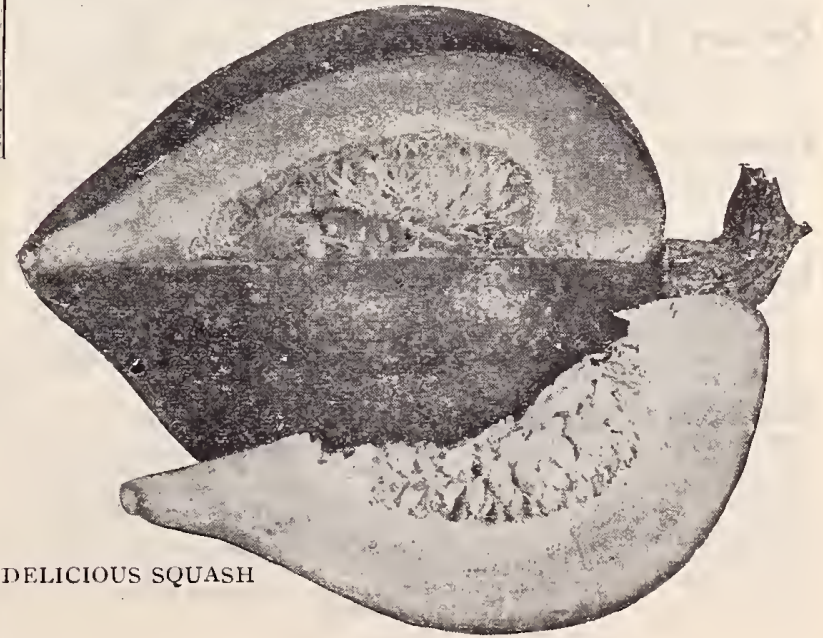




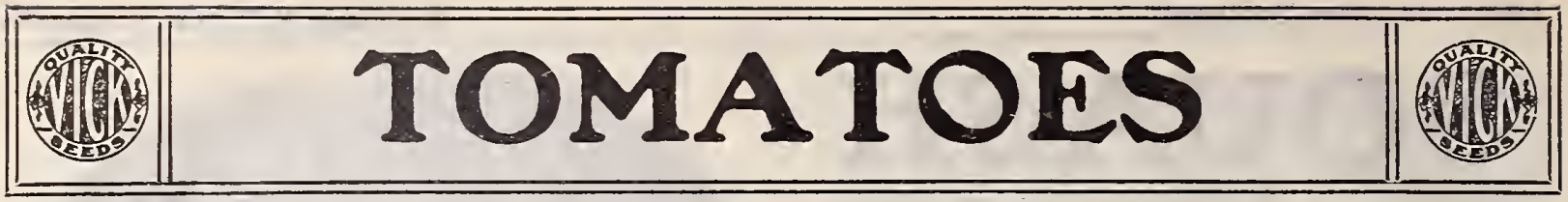

WERY good plants can lie grown in. boxes in the house, but to oltain fruit very early, sow in a hotbed in March. In about five weeks plants should be transplanted to another hotbed, setting them about four or five inches apart. Here they should remain, having all the air possible, until after the middle of May, when they may be put out in the ground, four feet apart each way. If not too early or too cold, a coldframe will answer for the first transplanting. The soil for early Tomatoes should not be too rich, and a warm, sheltered location selected, if possible. Pinching off the ends of the branches when the first fiuit is set, will hasten the ripeuing very much. One ounce will produce 2000 plants; one-quarter pound (to transplant) for an acre.

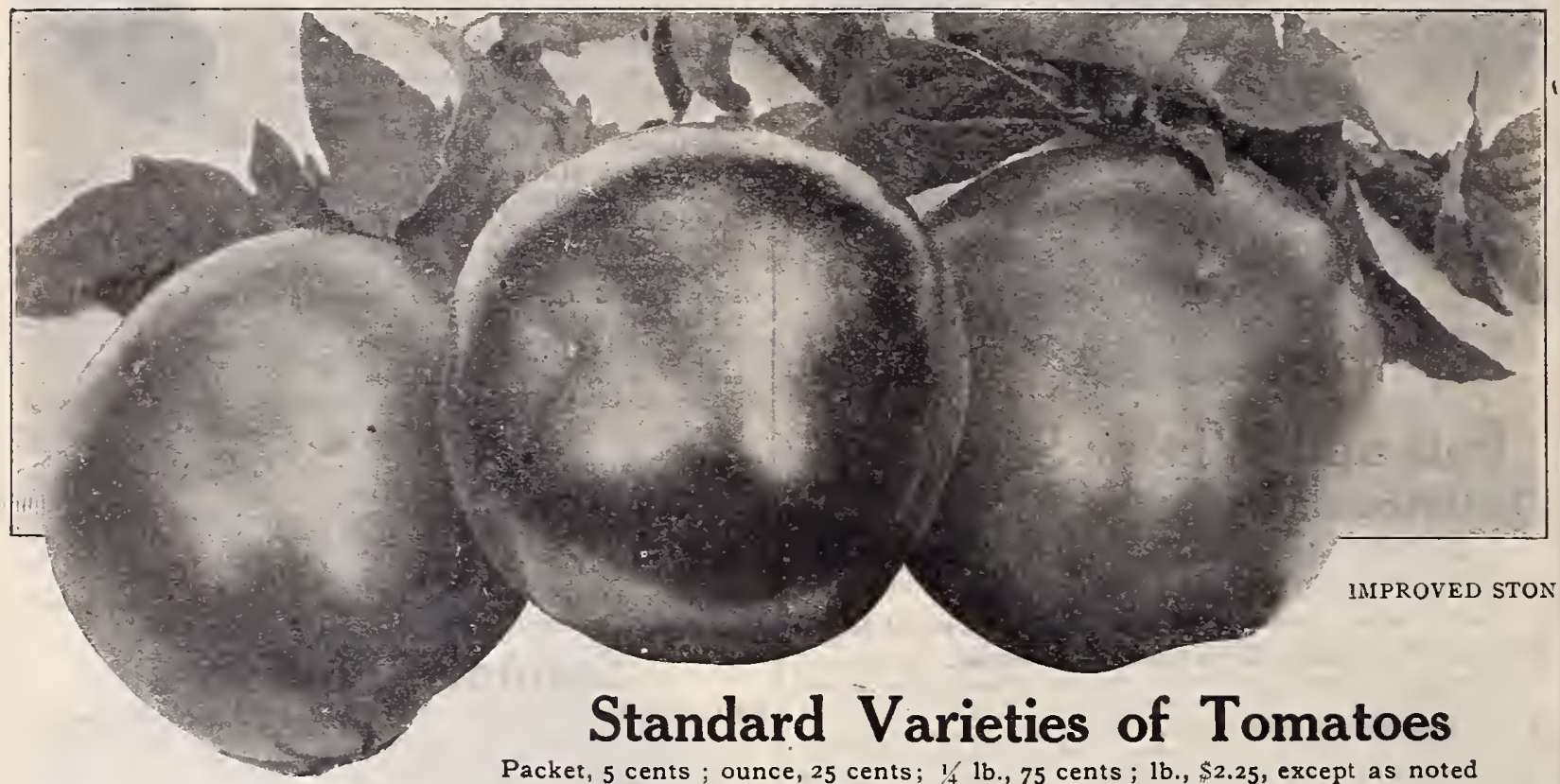

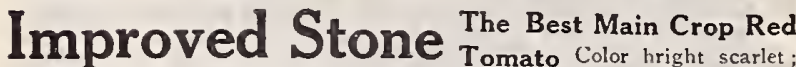

very smooth; ripening even to the stem without a crack; exceedingly solid and firm fleshed; an excellent shipper; quality the very best; not subject to rot; its appearance on market remarkably attractive; a heavy variety. It is the standard main crop Tomato for market gardeners and truckers, and superior for canning.

Dwarf Stone. Fruit like Improved Stone. The strong, upright growth allows very close planting. The planis may be set 18 by 24 inches apart and yet produce an abuudant crop. Packet

oz., $x_{5}$ cents; oz., 25 cents; $1 / 4$ lb., 80 cents ; lb., \$3.00.

Chalk's Early Jewel A fine second-early Tomato about ten days later than Earliana. Fruit large size and fine flavor. The plant are compact and strong, one of the liest for shipping and the home garden. Continues bearing throughout the Suinmer. Packet, 5 cents; $1 / 2$ oz., 15 cents; oz., 25 cents; $1 / 4$ lb., 75 cents; 1 b., $\$ 2.50$.

Living'ston's Coreless Immenselyproductive: strong outside and inner wall of flesh of the Livingston's Coreless render it a very firm fruit and one of the best for long distance hauling or shipping. Color bright red. Packet, 5 cents; $1 / 2$ oz. Is cens; $0 z ., 25$ cents; $1 / 4$ lb., 75 cents; 1b., $\$ 2.50$.

Golden Queen (Queen of the Yellows).

mooth, large in sizend ripens early. Jakes handsome, rich preserv. This Tomato more delicate than that of the red varieties, the flesl finer-grained and very tender. Try it. Packet, 5 cents; 0z., 30 cents; $1 / 41$ b., 85 cents; 1 b., $\$ 3.00$ Stirling Castle. A fine variety for forcing purposes, and for outdoor planting whell grown on a single stem. The fruit is round and deep, of medium size, smooth, free from cracks or watery cavities, and almost seedless : color bright scarlet. Very early. Packet, 20 cents.

\section{Dwarf Champion} short-jointed stems, requiring no stakes. Often sold as 'iree Tomato. Can be planted as close as three feet. Unsurpassed as a cropper. Colin deep red, with a purplish tinge. Round and smooth.

Crine's June Pink. "A purple pink selection from Earliana. The frut is smooth and the plant a good yielder. Packet Io cents ; 1/2 Oz., 20 cents; $0 z ., 25$ cents; $1 / 4$ lb., 80 cents; 1b., \$3.00.

PO 1 P Purplish pink tomato of the largest size. Very 2O derosa. meaty, few seeds, and free from acid. Ripens

Plum-Shaped Yellow. Handsome in appearance and valuable for preserving. Excellent served raw with pepper and vinegar.

Pear-Shaped Red. True pear-shaped, small, bright red. Used for preserves and for making "Tomato figs."

Pear-Shaped Yellow. Same as the above, except that color is yellow. Red Cherry. Small, perfectiy round and smooth, bright red, borne in large clusters. Fine for preserves and pickles.

Yellow Cherry. Differs from Red Cherry only in color.

Husk or Strawberry (Winter Cherry, etc). Fruit golden yellow, size of a rherry. Fine for pies, preserves, or eating from the liand.

Packet, zo cents; 0z., 35 cents; $1 / 4 \mathrm{lb}, \$ 1.00 ; \mathrm{lb} ., \$ 3.50$.

\section{OTHER STANDARD VARIETIES}

Packet, 5 cents; oz., 25 cents; $1 / 4 \mathrm{lb}$., 75 cents; $1 \mathrm{~b}$., $\$ 2.50$.

Honor Bright, Livingston's Favorite, Improved Trophy, Bright and Early, Perfection, Peach, Beauty, Royal Red. 


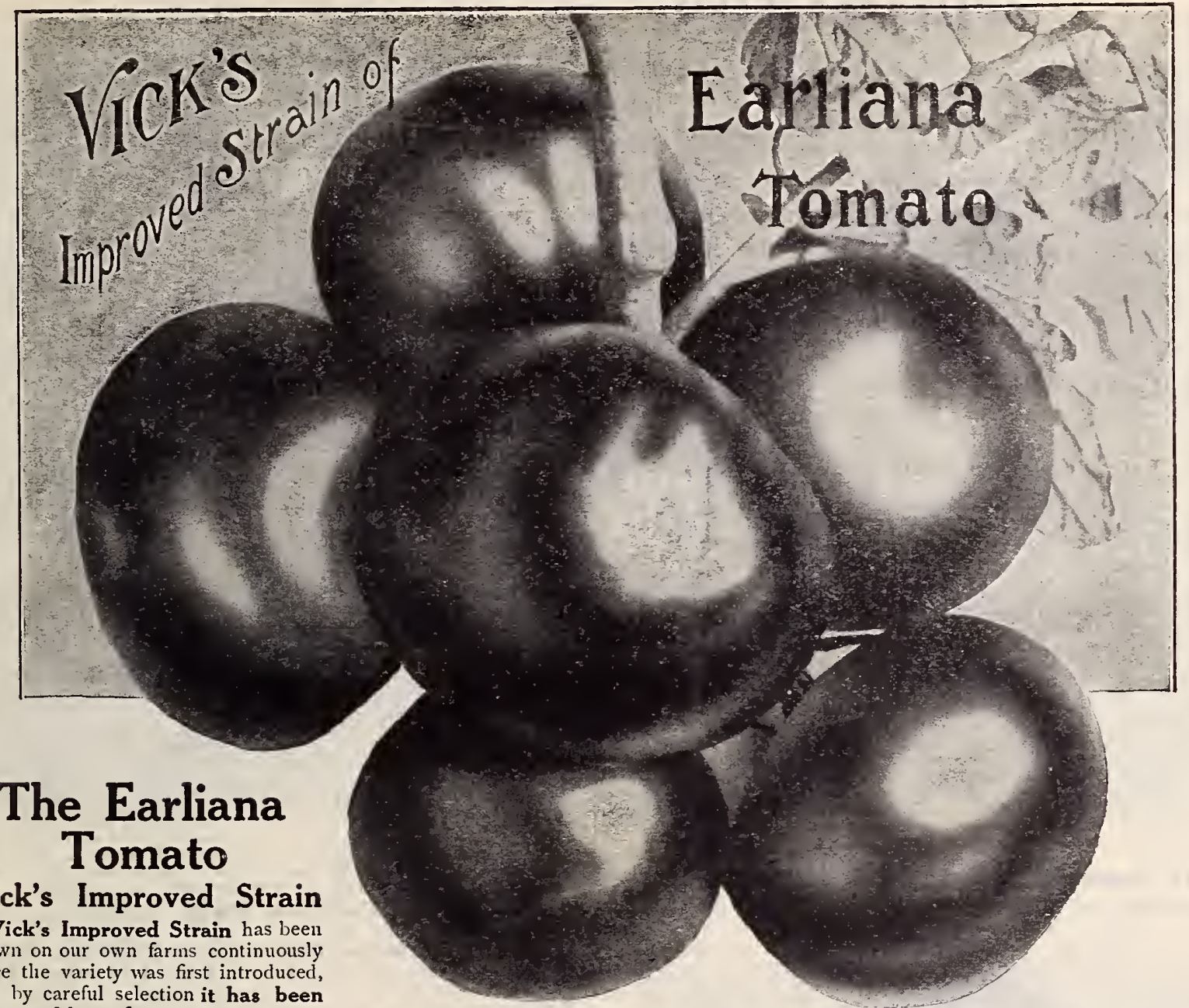

and hy careful selection it has been improved by us from year to year.

Vick's Improved Strain now grows uniformly, round and smooth. In this respect it is a great improvement over the ordinary stock of Earliana.

Vick's Improved Strain sets its fruit thickly in the center of the plant. Our plants, last summer, looked as though the Tomatoes had been poured out of a basket.

Vick's Improved Strain ripens its main crop early. Instead of ripening one at a time at intervals through the whole season, nearly the whole crop ripens within a remarkably short time.

Vick's Improved Strain is the most profitable Tomato that can be grown by the Market Gardener and Truck Farmer.

Vick's Improved Strain ripens up to the stem better than any other variety of early Tomato now on the market. It has a good bright red color. It is a solid, meaty Tomato of good flavor, and first class for canning and catsup.

Vick's Improved Strain has a small growth of vine and may be planted two and one-half by four feet, effecting a great saving of space over the late varieties.

Packet, ro cents; half ounce, 25 cents ; Ounce, 40 cents ; quarter pound, $\$ 1.25$; pound, $\$ 4.00$.

\section{TOBACCO}

Connecticut Seed-Leaf. Packet, 5 cts.; oz., 25 cts.

Havana, or Cuban Packet, $10 \mathrm{cts}$; oz., $40 \mathrm{cts}$.

A few years ago I became interested in your Earliana Tomato, and ordered a small package of you. At first I was not successful zuith them, but I saw my mistakes, or part of them at least, and made some improvements in the manner of cultivation. You know we hear a great many stories from Florida, Texas and Kansas; but here is one from Sullivan County, northern Missouri. This sunmer $I$ had a small place in the garden, $25 \times 34 \mathrm{ft}$., -about on -fiftieth of an acre-on which I produced $\$ 43.00$ worth of Earliana Tomatoes, besides what we used on the table and gave to the neighbors. How is that for Vick's Earliana Tomato and poor old Missouri? 


\section{TURNIPS}

SOW in drills from tweve to eighteen inches apart, and half an inch deep. In $S$ this climate we sow from the $25^{\text {th }}$ of July until the middle of August. Swede or Rnta Baga Turnips should be sown the first of June, the rows being about eighteen inches apart, and the plants in the rows not less than ten inches. One ounce of seed will sow 200 feet of row ; and two to three pounds are required for an acre in drills.

Packet, 5 cts.; oz., Io cts.; I/ 1 b., 20 cents; 1 b., 60 cts.; except as noted.

Purple-Top Strap-Leaved. $\begin{gathered}\text { Flat, } \\ \text { size, medium } \\ \text { purple }\end{gathered}$ above ground, white below. The most popular varety for early use, either for table or stock.

Early White Flat Dutch, Strap-Leaved. Similar to above. A fine, early, white sort, of quick growth and excellent quality.

Purple-Top White Globe, An improved purple-top flat Turnip; globular in shape, of fine appearance, a good kecper of excellent quality and equally desirable for table or stock.

Extra Early Purple-Top Milan. A white variety, purple-top and strap-leaf. 1'his, with the White Milan is the earliest of all lurnips; remains in good condition a long time. $1 / 4$ lb., 25 cents ; 1b., 80 cents.

Extra Early White Milan. Similar to above except it is pure jvory white in color, and about one week earlier. I/4 lb., 25 cents; 1 b., 80 cents.

Early White Snowball or Six Weeks. A perfectly globe-shaped white-skinned Turnip of medium size and excellent flavor. For early sowing this is one of the best, being crisp and tender, and maturing in six weeks from the time of sowing. A good keeper. Fine for family or market. $1 / 1 b$., 25 cents ; lb., 80 cents.

White Egg. An excellent variety. Nearly oval or eggshaped. Flesb firm and fine-grained, and of snowy whiteness. Its flavor is of the very best, Particularly desirable for table. Can be sown as late as the middle of August.

Long White Cow-Horn. A quick-growing sort, half-long in shape fine-grained, sweet, good quality. Roots grow partly above ground. Very productive. Aluch used for a cover crop.

Grey Stone. Grows very large, perfectly round, white, reddish gray best summer varieties. Ounce, 15 cents; $1 / 4 \mathrm{lb} ., 35$ cents; $1 \mathrm{~b}$., $\$ 1.00$.

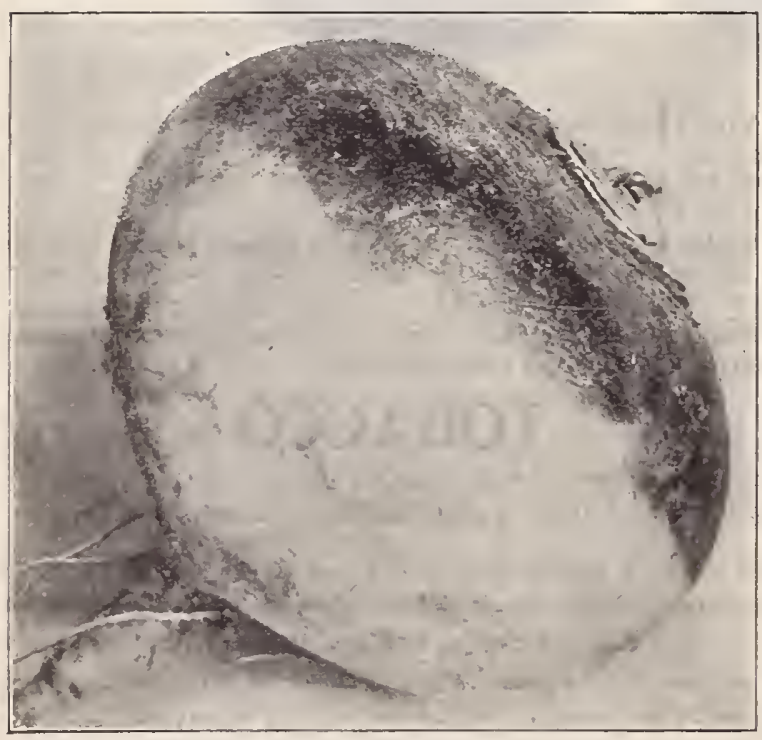

PURPLE-TOP WHITE GLOBE

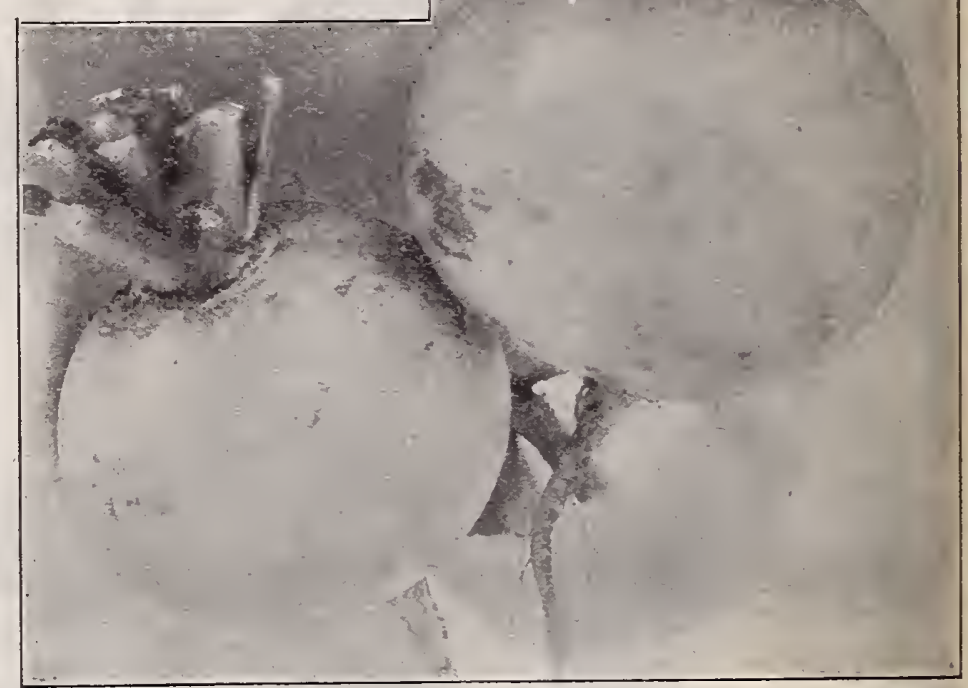

EARLY WHITE SNOWBALL

Orangie Jelly. This is the most distinct yellow Turnip ever offered It is of very fine texture, and the best, sweetest, and most delicious of the yellow-fleshed varieties. It is of medium size, with small tap-root, 2 rapid grower, matures early, and keeps well. A superior table variety. Packet, 5 cents ; oz., Io cents ; $1 / 4$ lb., 20 cents ; lb., 70 cents.

Robertson's Golden Ball. Similar to Orange Jelly, but larger and not so fine-grained.

Large Yellow or Amber Globe. Good for general crop. Excellent for table or for stock-feeding. Flesh yellow, firm, and fine-grained. A good keeper and cropper.

Yellow Aberdeen. Roots medium size, round, flesh yellow, tender and sugary. Very hardy and productive. A good keeper. Good for both table and stock.

Yellow Stone. One of the best jellow-fleshed sorts for table use and stock Pomeranian White Globe. Very productive, in good soil roots fre. quently grow from ten to twelve pounds. Good for table or stock-feeding.

Large White Norfolk. A standard variety for field-culture for stock feeding. Grows to a large size and is very productive.

\section{RUTABAGAS, or Swede Turnips}

Packet, 5 cents; ounce, Io cents ; $1 / 41$ b., 20 cents ; 1b., 60 cents. In lots of 5 lbs., 40 cents per lb., express not paid. White Sweet Swede. A large, white, solid Swede, sometimes called White Russian. Quite desirable for table or stock-feeding. A great yielder. Fine form and good keeper.

Vick's Imperial Purple-Top Yellow An excellent variety either for the table or cattle-feeding. Flesh yellow, firm. solid, rich, and sweet. Very hardy, prolific, tender. A splendid keeper,

Laing's Purple - Top Strap-Leaved. A large early sort of fine quality. Flesh yellow, very sweet. Tops peculiar in that they are strap,

Pajbjerg Bangholm New. This variety is tbe of all Ruta Bagas or winter Turnips in Denmark. Tbe most productive yielding more to the acre than any variety we bave tested. The lower half of the root is yellow, gradually shading to a violet toward the top. Packet, 5 cents; ounce, 15 cents; $1 / 4$ lb., 35 cents; lb., \$1.00. 


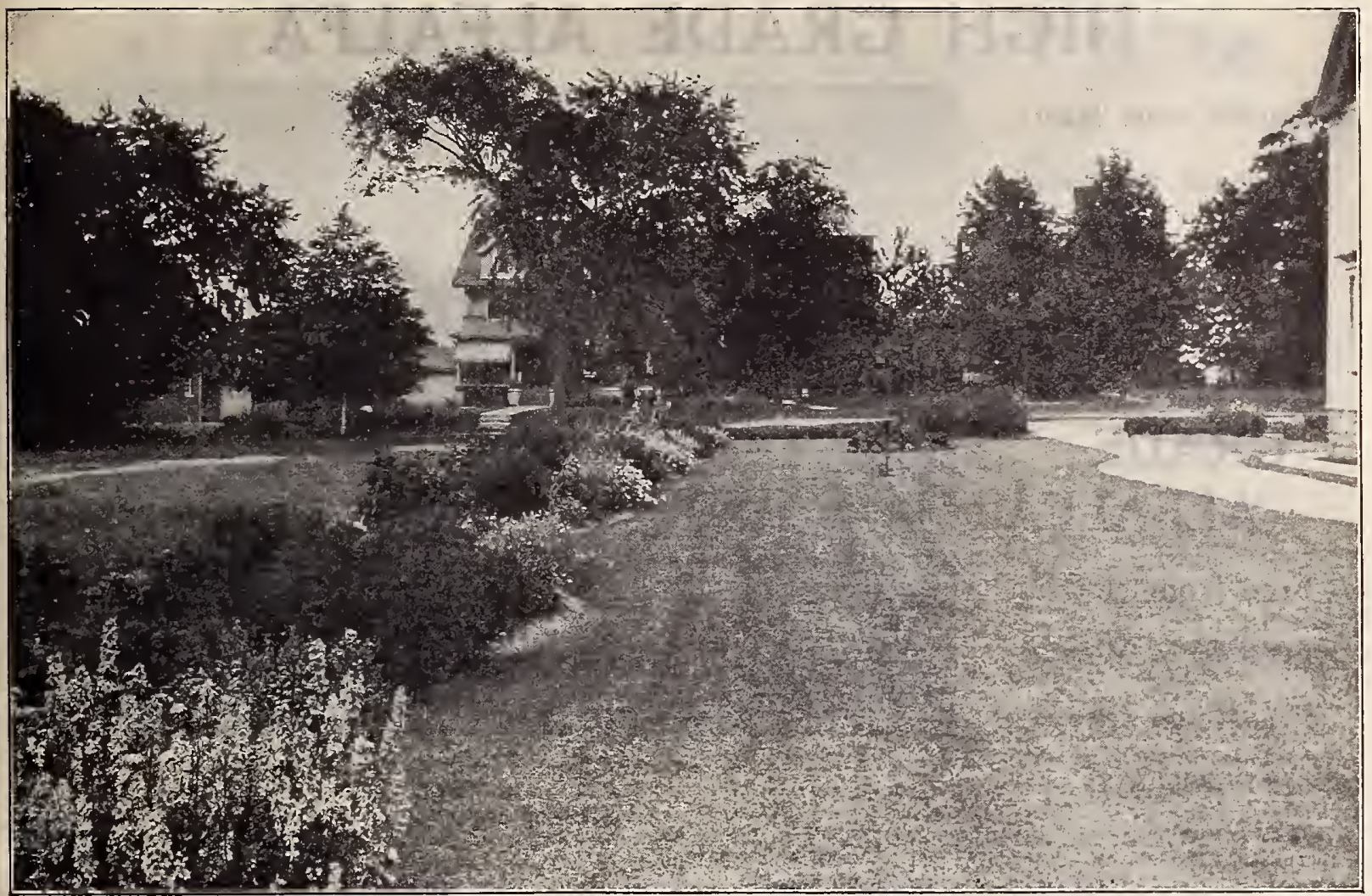

\section{Vick's Velvet Lawn Grass}

To make a perfect lawn, good seed is absolutely essential. Vick's Velvet Lawn Grass Mixture is composed of pure seed and contains no chaff or weed seed. Unsurpassed by any other mixture, regardless of price. Under ordinary conditions a velvet lawn is assured in a few weeks after sowing Vick's Velvet Lawn Grass Mixture.

Good results are only to be obtained by using a mixture of several grasses. The different varieties of grasses are at their best at different times during the spring, summer and fall. Our Velvet Mixture contains the right kinds in correct proportions, and will produce a thick sod of rich deep green throughout the entire growing season. Only the highest grades of seed are used. The White Clover in the Velvet Lawn Grass costs fifty per cent. more than the grade used in many mixtures.

IMPORTANT NOTICE. Do not mix Timothy or any other grasses with our Velvet Mixture. Rely on us. Our mixture is correctly proportioned, and will give you entire satisfaction.

Vick's Velvet Lawn Grass weighs twenty pounds per bushel, A bushel of our Lawn Grass will go fully twice as far as any of the ordinary mixtures of fourteen pounds per bushel we have ever seen.

Price, postpaid, per quart, 35 cents; per lb., 50 cents.

By express or freight, charges not prepaid. Five lbs., $\$ 1.50 ;$ 10 lbs., $\$ 2.75,201$ bs., (I bu.) $\$ 5.00$.

\section{Vick's Shady Spot Lawn Grass}

In many places, especially in villages and cities, there is so much shade that ordinary lawn grass does not succeed. To meet such conditions we have arranged a special mixture based on our long experience with grasses, which we believe will give perfect satisfaction in nearly all locations. The seed used is thoroughly recleaned, free from weed seeds, and weighs twenty pounds per bushel.

Price, postpaid, per quart, 35 cents; per lb., 50 cents.

By express or freight, charges not prepaid. Five lbs., $\$ 1.50 ;$ Io lbs., $\$ 2.75 ; 201$ bs., (I bu.) $\$ 5.00$.

To ascertain the necessary quantity of Vick's Velvet Lawn Grass or Vick's Shady Spot Lawn Grass use the following rule :-

Use one quart of seed to the square rod; one pound to 450 square feet; 100 pounds ( 5 bushels), to one acre, (43,560 square feet)

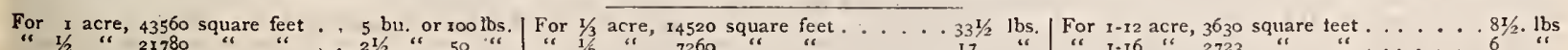

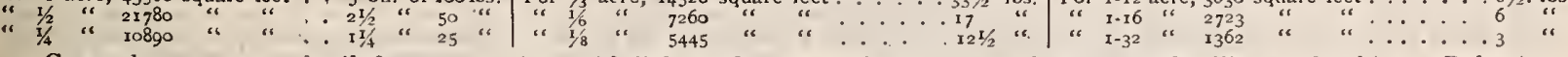

Cover clay spots or subsoil from excavations with light surface soil. Settle and level by repeated rolling and raking. Rake in a liberal amount of Vick's Pulverized Sheep Manure. It will not burn the seed. For full particulars see Page Io2. Sow when the ground is ready and keep the lawn sprinkled, if possible, until the grass is well established, 


\section{HIGH GRADE ALFALFA}

Enrich your land

Increase your crops

Fill your purse

by growing

HIGH

GRADE ALFALFA

\section{Free from Dodder}

\section{Free from Weeds}

\section{Free from Dirt}

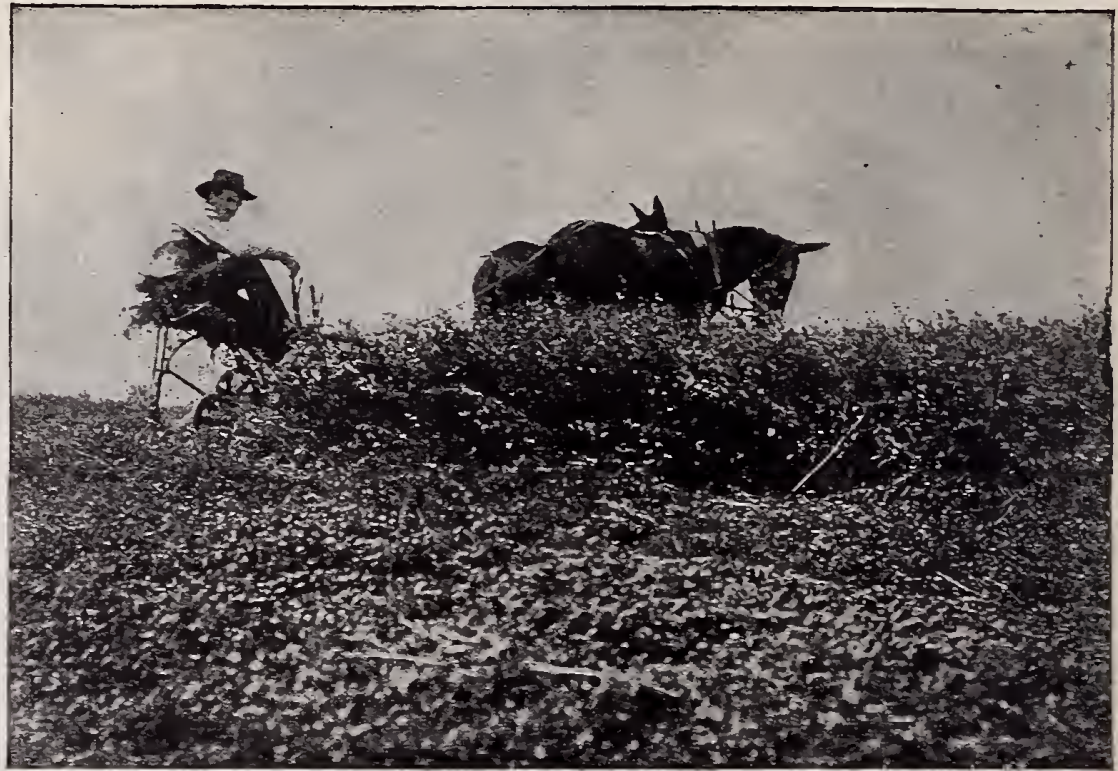

Are you growing Alfalfa? The farmer who does not look into the possibilities of putting a good field of Alfalfa on his farm is neglectful of his own best interests. We have three fields of Alfalla on our own farms and the Alfalfa has proved to be a splendid money making crop. We are feeding it to all kinds of stock and we find it more valuable for feeding than Timothy or Clover, besides giving a greater yield. One of these fields has been in Alfalfa for five years, without top-dressing or re-seeding, and it is still yielding over three tons to the acre of splendid hay, each year. We know fields in this state that have been in Alfalfa for from ten to fifteen years which are still producing fine crops.

The demand for Alfalfa Seed is growing at a surprisingly rapid rate. The acreage in New York State today is probably ten times what it was five years ago; in fact, there are now thousands of acres of Alfalfa in this state.

Do not take any chances on doubtful Seed when preparing for a crop of such value and permanence as Alfalfa. WVe liave been at great pains to secure the finest Alfalfa seed that could be had. We believe that every progressive farmer, - the one whose trade is worth having, - is willing to pay a fair price for good seed.
Our Alfalfa Seed is specially grown for us at a high altitude and on dry land. This insures, for our seed, hardiness and a high percentage of germination. We have a beautiful stock, free from weed seeds, plump, and of a good bright color. Before this seed was accepted by us it was tested by a Government Experiment Station. This official report shows that our Alfalfa Seed comes up to the very highest standard of purity.

There is better value for the money in seed of this character than in low grade Alfalfa seed at a less price. Large quantities of inferior seed are in the market every year, some of which contains dodder, -an extremely noxious pest. Sume is poorly cleaned, containing large percentages of dirt, weed seeds and shrunken Alfalfa seed. Some is imported Alfalfa seed containing adulterations and undesirable foreign weed seeds. After the trash and poor seed has been taken out of a low grade sample, the good seed that is left invariably costs more per pound than is asked for seed of the highest quality.

PRICES. Postpaid. Ounce, 5 cents; pound 40 cents.

Express or Freight, not prepaid. Pound, 30 cents; ten pounds, $\$ 2.1_{5}$; thirty pounds, $\$ 6 . \infty$; sixty pounds, $\$ 10.75$.

\section{BOOKS FOR GARDEN OR GREENHOUSE}

\section{Posiage or Express Charges prepaid on any of these Books.}

Alfalfa. Its growth, uses and feeding value, to- The Amateur's Practical Garden Book. By yether with notes on its history, botany, etc. By $\vec{F}$. D. Coburn. Illustrated, cloth, $160 \mathrm{pps}$. 50 cents Asparagus. Its culture for home use and for niarke. By F. M. Hexamer. Handsomely illustrated, $5 \times 7$ inches, 170 pages, cloth. 50 cents

Cabbage, Cauliflower and Allied Vegetables. From Seed to Harvest. By C. L. Allen. A practical treatise on the various types and varieties of cabbage, cauliflower, broccoli, Brussels sprouts, kale, collards, and kohl rabi. Illustrated, 142 pages, I2mo, cloth. 50 cents

Celery Culture. By Prof. W. R. Beattie. In this work complete cultural directions are included, together with the estimate of cost for equipment and running expenses, and a fair estimate of re. turns from one acre.

How to Make Money Growing Violets. Sali. ford.
C. E. Hunn and L. H. Bailey. Contains comthings about the bouse and garden. $\$ 1.00$

Garden Making. By L. H. Bailey. Contains directions for buildings fences and hedges, preparation of land, planting trees and shrubs; in sects and diseases, tools, lay.ing out grounds, lawn making and planting, pruning trees, raising flowers, vegetables and fruits.

I. 50

Horticulturists' Rule Book. By L. H. Bailey. iseful information for fruit growers, flurists and gardeners.

$\$ 1.50$

Onion Culture, The New. By $T$ Greiner. This work is fill of new, original and highly valuable matter of material interest to every one who raises onions in the family garden, or by the acre for market.
Greenhouse Management. By L. R. Taft. A manual for florists and flower lovers on Forcing Flowers, Vegetables and Fruits.

Mushrooms. How to grow.

$\$ 1.50$ How to Grow Mushrooms. By Wm. Falconer. A practical treatise on Mushroom Culture for profit and pleasure.

$\$ 1.50$

Roses and How to Grow Them. A manual for growing roses in a garden and under glass. Illus. trated, $12 \mathrm{mo}$, 189 pages.

The Small Fruit Culturist. By A. S. Fuller. Fqually adapted to the needs and requirements of the private cultivator and the large grower. Illustrated.

Practical Potato Culture. By E. A. Kogers. The entire subject is covered in a clear, thorough and interesting manner by a practical and successful grower. $\$ 28$ pages. Illustrated $50 \mathrm{cents}$

We can supply (at regular prices) any Horticultural book published.

Send us a list of your needs and we will be pleased to quote prices. 


\title{
GRASSES and CLOVERS
}

Prices on bushels and roo pounds subject to change without notice. Markets on grass seeds vary from day to day.

We invite inquiries and will cheerfully quote best prices by return mail.

\begin{abstract}
At pound priee we prepay postage. All other prices wre bused on puyment of express or freight by the purehaser.
\end{abstract}

(Not less than to pounds of any variety at the soo pound price.)

\section{GRASSES}

Timothy (Phleum pratense). A field and not a pasture grass, as it will not endure close and frequent cropping: but for a hay crop oll strong soils it will produce more than any other sort. One-fourth to one-half bushel per acre. King Brand, pound, 30 cents; bushel, 45 pounds, market price.

Kentucky Blue Grass (Poa pratensis). In conjunction with White Cluver it forms the finest and closest turf. As a pasture grass it furnishes the most nourishing food for cattle of any kind, until winter; thrives on a variety of soils, but does best in dry and somewhat shady localities. Sixty pounds for lawn and twenty pounds per acre for pasture. Extra faricy, re.cleaned. Pound, 35 cents; per bushel, (r4 lbs,) \$3.25; roo lbs., $\$ 22.00$.

Fancy Red Top (Agrostis vu(garis). Valuable in a mixture for either lawns, pastures, or meadows, growing in almost any soil, moist or dry. For lawns forty-five pounds; for pasture twenty-five to thirty pounds per acre. Fancy cleaned. Pound, 50 cents ; $100 \mathrm{lbs.,} \$ 37.50$.

Orchard Grass (Dactylis glomerata). One of the very best pasture grasses exceedingly palatable to stock, will endure a good deal of cropping. One and one-lialf to two bushels per acre. Pound, 35 cents; 100 libs., $\$ 22,00$.

Creeping Bent, or Fiorin (Agrostis stolonifera). Desirable for mixing with other lawn or pasture grasses, as it thrives in moist land, on which water does not stagnate. 2 to $2 \frac{1}{2}$ bushels per acre.

Pound, 50 cents : 100 lbs., $\$ 37.00$.

Bermuda Grass (Capriola Dactylon). Invaluable for crop in the South, standing a greater degree of heat than any other known grass.

Pound, \$1.10.

Sweet Vernal Grass, True Perennial (Anthoxanthum odoratum). The chief merit of this grass lies in its fragrant odor. In a mixture for lawns and pasture lands it is invaluable. Pound, 75 cts.; ounce,

Annuar, Sweet Vernac, (Anthoxanthum Puelii). Pound.

Tall Meadow Oat Grass (Azrena elatior). Valuable for pasture. Four bushels to the acre. Bushel, 14 pounds. Pound, 40 cents ; I00 Ibs., $\$ 25.00$.

Hungarian Brome (Bromus inermis). A perennial grass especially suited to dry lands and regions subject to severe droughts. It does well in all parts of the couniry, North and South. It grows most rapidly in sandy soils, but will establish itself on the heaviest lands. 25, pounds of seed per acre. Pound, 35 cents ; 100 lbs., $\$ 22.00$.

Meadow Fescue (Festuca pratersis). Excellent pasture grass. Sow in a inixture with other grasses, as Orchard Giass, Rye (rrass, or Kentucky Blue Grass. 40 lbs. per acre. Pound, 35 c-nts ; 100 lbs., \$22.00.

Sheep's Fescue (Festuca ovina). Low growing grass, with an abundance of fine, narrow leaves. Valuable for grazing, especially on light soils. About 30 lbs. per acre. Pound, $4^{\circ}$ cents; 100 pounds, $\$ 25.00$.

Perennial Rye Grass (Lolium perenne), Valuable for permanent pasture it mixture with other pasture grasses. One and one-half to two bushels per acre. Pound, 25 cents; 100 lbs., $\$ 10.00$.

Italian Rye Grass (Lolium Italicum). Usęd in Europe for soiling. Gives early, quick and successive growth, till late in fall. Two bushels to the acre Pound, 25 cents ; roo lbs., \$10.00.

Hungarian Grass (Panicum Germanicum). Valuable soiling plant, May be sown as late as first of July, and produce a large green crop. One bushel to the acre. Bushel, 48 pounds. Pound, 20 cents ; bushel. $\$ 250$.

German, or Golden Millet. Medium early fornge plant, prolific in stalk and grain: $3^{8}$ pounds per acre. Bushel, 50 pounds. Pound, $20 \mathrm{cts}$; bushel, $\$ 2.50$.

Japanese Barnyard Millet (Panicum Cris-Galli) Enormously productive. yielding from fout to six tons of cured forage per acre, on rich soils. Six to eight feet in height. Sow in May. Broadcast, ten to fifteen pounds per acre or in drills. eight pounds per acre. 32 pounds per bushel. Pound, 20 cents; I00 lbs., \$8.00.
Special Grass Mixtures

These Mixtures are well proportioned. They are marle up of the best grasses, both American grown and imported, for the purposes desired. All are permanent, and when once established, will last indefinitely, if the soil is kept up by occasional topdressing.

Standard Hay Mixture. For general hay lands : containing six varieties of grasses. Pound, 35 cents ; bushel, ( 14 lbs.) $\$ 3.00$.

Standard Pasture Mixture. For ordinary pastures, where the land is neitler very wet nor very dry. Pound, 35 cents; bushel, ( 14 lbs.) $\$ 3.00$.

Dry Pasture Mixtrre. For high and dry pastures: containing grasses that withstand exposure and severe weather.

Pound, 35 cents; bushel; _(14 Ibs.) $\$ 3.25$.

Wet Pasture Mixture. Made up of grasses especially adapted to damp places. Pound, 40 cents; bushel, $(14,1$ bs.) $\$ 3.50$.

All the above mixtures are made up to sow $4^{2}$ pounds to the acre.

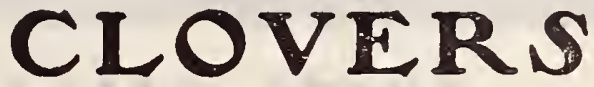

Special Quotations for Large Quantities

Our Clover Seed has all been thoroughly tested. We do not accept a pound of Clover Seed until a satisfactory test shows it to be of the highest grade. No purchase is closed if the tests show even a trace of dodder. It must be practically free from all other noxous weeds, dirt or other impurities. When Clover Seed is high priced, buyers are tempted to look for cheaper seed; but they get less good, sound, plump seed for their money in the lower grales. Why pay Clover Seed prices for dirt, weed seeds, and shriveled Clover seed that will not grow? It is just a question of arithmetic.

\section{"KING BRAND" of Clover and Timothy}

"King Brand" appears upon our high grade of both Timothy and Clover, and indicates that the seed is pure, fresh and of the highest vitality.

We shall make our prices just as low as the market conditions will warrant.

Red Clover, King Brand, per pound, postpaid .. . . . 35 cents Timothy, King Brand,

Samples furnished free upon application. Special quotations on large quantities.

Scarlet, or Crimson (Trifolium incarnatum). Most valuable crop for green manurung, soiling, hay, pasture, and ensilage. It is an annual and mustbe sown every year. Improves worn out and poor soils, and is the cheapest and best fertilizer. Should be sown in August and September Sow to to 15 pounds per acre. Bushel, 60 pounds. Pound, 25 cents bushel, market price.

Alsike, or Swedish (Trifoliun hybridum). Thrive in rich, moist soil. Does not succeed on ligh, dry lands. Eight pounds per acre. Pound; 35 cents ; bushel, market price.

White (Trifolizm repens). Valuable to mix with lawn grass; should be in every mixture for permanent pasture. Io lbs. to the acre, half the quantity when sown with other grasses. Ounce, 5 cents; $1 \mathrm{~b}$., 50 cents ; roo lbs., market price.

Sweet, or Bokhara Melilotus alba. Makes excellent food for hees.

Ounce, 5 centa : lb., 35 cents. 


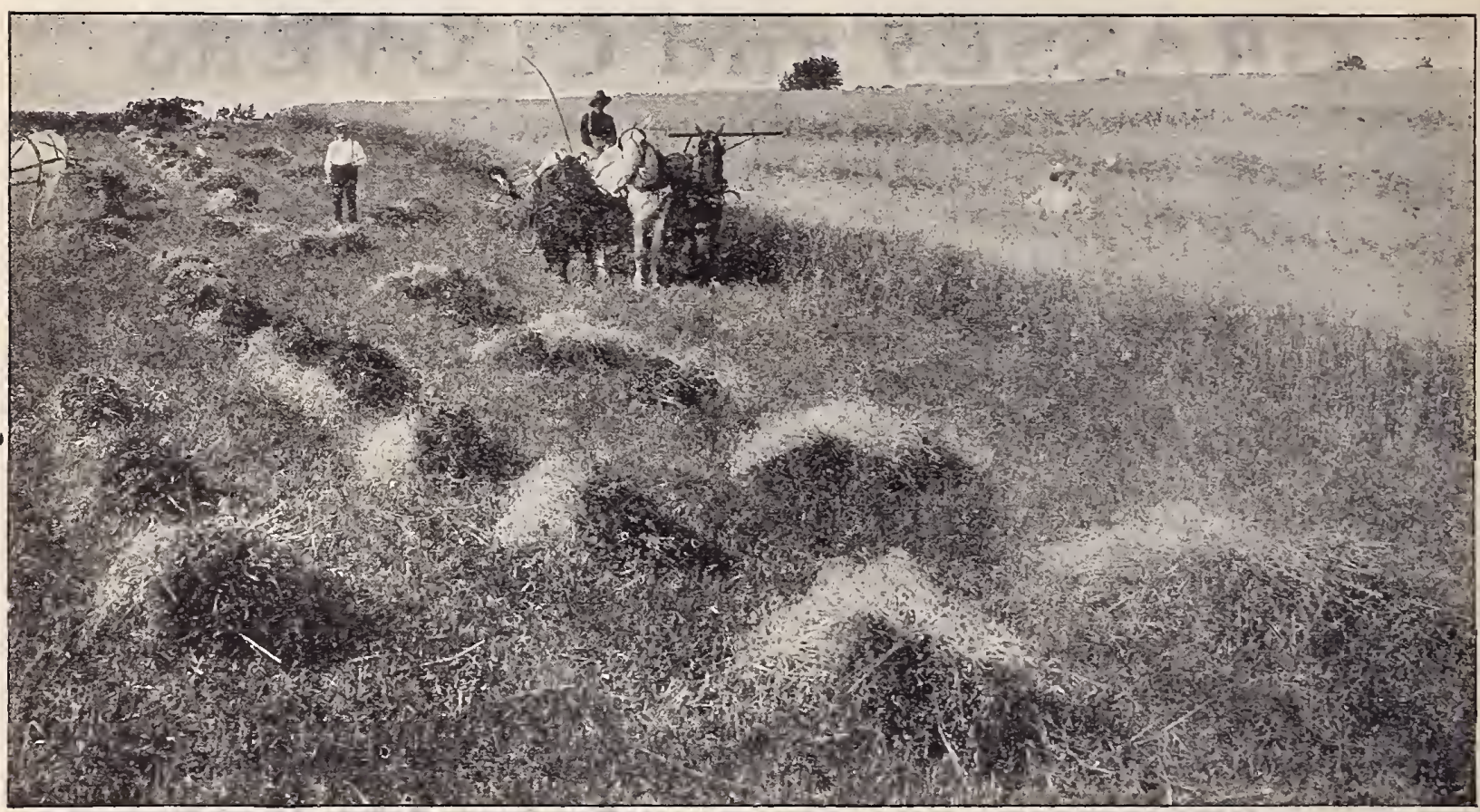

\section{VICK QUALITY FARM SEEDS}

At Pound or Quart Prices, Postage Prepaid. Pecks or Bushels by Express or Freight, Not Prepaid. Special Prices on Large Quantities.

\section{ARTICHOKE}

Jerusalem Artichoke (Helianthus tuberosus). Artichokes are planted like potatoes. Encrmously productive and thrive in any soil. They are very hardy, and will stand freezing and thawing. Hogs will grow faster and become more healthy on them than on any other feed. Quart, 35 cents ; peck, 75 cents; bushel, $\$ 2.50$.

\section{BARLEY}

Hulless. Hulless, like wheat, when threshed. Ripens early and very produc:ive. Pound, 25 cents; peck, 75 cents; bushel, \$2.25.

Early Russian Six-Rowed. The best for malting, and a heavy yielding variety. Peck, 60 cents; bu., $\$ 2,00$.

Champion Beardless. Eariy and prolific. Peck, 75 cents; bushel, \$2.25.

Manshurey. The most productive six-rowed variety. Ripens early, with strong, stiff straw. Peck, 60 cents ; bushel, $\$ 2.25$.

\section{BEANS}

Soja Bean, Valuable as forage or fertilizer. Thrives well in ho: and dry weather. Sow broadcast one-half bushel to the acre, or in drills three feet apart and one foot between plants. Pound, 25 cents ; bushel, $\$ 3.50$. Velvet Bean. Used in the South. Extremely preductive and valuable is forage or for fertilizing. Yound, 25 cents ; peck, $\$ 1.5^{\circ}$; bushel, $\$ 5.00$.

\section{BROOM CORN}

Improved Evergreen. This variety is now grown more extensively than any other, on account of its straight, loug, light green brush. It is vely productive. Sow six pounds to an acre. Pound, 20 cents; $100 \mathrm{lbs}, \$ 6.00$.

\section{COW PEAS}

This pea has always been valuable for improvement of the soil. It is considered superior to clover for plowing under as a preparation for wheat, as it matures the first year from seeding. Plant seed in a thoroughly pulverized warm soil. If wanted to plow under for manure, sow in drills one fool apart. If New Era, Clay, Whippoorwill, Mixed, All above varieties; $\$ 1.00$ per peck; $\$ 3.50$ bushel.

WHEAT

WINTER-Peck, 5o cents : bushel, \$1.60.

\section{OATS}

\section{Swedish or Washington}

THE IDEAL OATS FOR THE AMERICAN FARMER

This Stock is Absolutely Free From Weed Seeds

Swedish Oats grown on our farm the past summer yielded the largest, heaviest crop in the reighborhood. In fact, we have never seen a handsomer and plumper lot of Oats than our own farm grown stock. Seed weighs from 36 to 37 pounds to the measured bushel. This Oat is practically immune from rust, and it is the earliest and most bountiful cropper of the heavy growing sorts.

Pound, 25 cents; three lbs., 60 cents; peck, 50 cents; bushel, $\$ 1.50$. Bag containing $2 \frac{1}{2}$ bushels, $\$ 3.40$

\section{RAPE, Dwarf Essex, English}

Extremely valuable for furnishing a quick growth of forage. A vigorons strong growing turnip-like plant. Especially grewn for feeding sheep, but cattle, pigs, and milch cows do very well upon it. Sheep should have access to a grass pasture, on which the will feed alternately. with the Rape, thus keeping them in the best condition. A constant supply of salt in the Rape field is quite beneficial. For sheep pasture, sow in Mlay, and it will be ready for pasturing in July and August: or sown in June, or even "1p to the latter part of July, it will firnish a large amount of pasture or focder.

\section{Pound, 20 cents ; roo ibs., $\$ 8.00$.}

\section{BUCKWHEAT}

Japanese. The heaviest vielding variety, with very large kernels and litge brancling plants. Pound, 20 cents; peck, 50 cents ; bushei. $\$ \mathbf{r} .50$. Silver Hull. The best for flouring purposes. Kernels smaller than Japanese, silvery gray in color. Fine stock, grown on our swn furm, Pound, 20 cents : peck, 50 cents; bushel, \$1.50.

FIELD CORN. See page $: ?$ 


\section{COLLECTIONS OF FLOWER SEEDS}

These collections, at special rates, are packed before the opening of the season and cantiot be clanged in any way. No premium aor cisccunt will be allowed of thesé Collections, but in all easea we prepay the postage.

\section{Branching Aster Collection}

This collection gives a full assortment of the colors found in the Brancling Class. 'These are unsurpassed for cutting; a harmonious color scheme for decorative purposes can easily be selected from these eight varieties.

White, Pink, Rose, Crimson, Carmine, Purple, Lavender and Dark Violet.

One packet of each of eight colors, $50 \mathrm{cts}$, postpaid,

How to Grow Asters, Their Culture and Care

Newly revised, enlarged and illustrated. Contains many new points of value, and is a practical instructor for tl,e Aster grower. Free with an order for Fick's Aster Seed amounting to 25 cents, or sent pustpaid on receipt of 10 cents without order for seed.

\section{Nasturtium Collections}

\section{Collection of Climbing Nasturtiums}

Eighteen varieties in separate packets, 50 cents, postpaid.

\section{Collection of Dwarf Nasturtiums}

Eighteen varieties in separate packets, 50 cents, postpaid.

\section{Snapdragon Collection}

\section{Antirrhinum}

The old favorite Snapdragon is growing in ponmlarity as a hedding plant, owning to the great variety of colors and the long time the plants remain in blonm.

Eight Separate Colors.

Collection of eight packets, postpaid, for 50 cents.

\section{Petunia Collection}

Large-Flowering Single, Superbissima

Vick's Single Fringed, Mixed Culors . . . . . . . . . .25

Single-Flowered Bedding, Extra Choice Mixed . . . . . . Io

Double-Dwarf Bedding, Mixed Colors . . . . . . ${ }_{2} 25$

Giants of California, Mixed Colors . . . . . . . . 20

Cne packe* each, postpaid, for $85 \mathrm{c}$.

$\$ 1.05$

\section{Double Zinnia Collection}

Eight Separate Colors.

Lilac, Purple, Crimson, Scarlet, Roie, Urange, Yellow, White Put up each color in a packet, postpaid, $30 \mathrm{c}$.

\section{Perennial Collection}

\section{A Permanent Flower Garden for $\$ 1.00$}

From the tall Hollyhocks and Foxgloves to the creeping Forget-me-not. Beginning in early spring with the Hardy Candytuft this collection will yield a succession of flowers each year until late in autumn. Full cultural directions will accompany each collection.

Culumbine (Aquilegia), New Large-Flowering

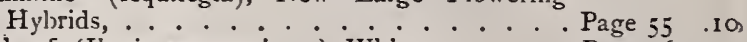

Candytuft (Iberis sempervirens), White. . . . Page 56 .10

Canterbury Bell, Single Mixed. . . . . . . . Page 56 .05;

Coreopsis lanceulata, Yellow ........ Page 55, .10,

Forget me-not (Myosotis palustris), the true per-

ennial Forget-me-not, Bltue......... Page 6r . ro

Foxglove (Digitalis), Mixed Colors. . . . . Paye 59.05

Blanket Flower (Gaillardıa grandiflora). . . . Page 60 . 10

Balsy's Breath (Gypsophila paniculata), White, 2 It. Page 59.05

Hollyhock, Duuble Mixed. . . . . . . Page 59 . 10

Ice and Poppy, Mixed Colors. . . . . . . . Page 68 .10

June Pinks (Dianthus plumarius), Doulle Mixed... . Page $5^{8}$.Io.

Larkspur (Delphinium), Large-Flowering Hybrids,

Mixed.

Oriental Poppy, Scarlet.

Page 6I .05

Page 68 .05

Scabiosa Caucasica, Lavender . . . . . . Page 73 . 10

Sweet William, Single Mlixed. Page 70.05

Shasta Daisy, White............ Page 69 . 10

$$
\text { I6 packets, postpaid, \$1.00. }
$$

$\$ 1.30$

Our "Hardy Plants, Old and New," beautifully illustrated mailed free on request. Descrilses Harily Plants, Roses, Shrubs. and Climbers, with directions for culture and time of blooming.

\section{Collection of Sweet Peas}

No flower surpasses the Sweet Pea in popularity, but mary people buy just "Sweet Peas" without thought of an assortment of colors or varieties. T' overcome this we have put up this collection. The assortment of 20 varieties gives a general collection of colors, including all of the most desirable shades. Only the latest and beit of the standard varieties are used in this collection.

Collection of twenty varieties, postpaid, for 30 cents.

\section{Vick's Collection of}

\section{Phlox Drummondi Grandiflora}

Phlox is one of the most sati-factory Annuals for hedding, blooming early in June tu late Fall. Nothing equals it for massing.

Fourteen different colo-s in separate packets for \$r.00.

Seven different culors for 55 cents.

\section{Vick's Collection of Verbenas

Striped Scarlet Pure White

Three varieties in separate packets, 25 cents, postpaid.

\section{SPECIAL BARGAIN COLLECTIONS PLANTS AND BULBS}

Every spring we have a surplus, due to the fact that some named varieries are called for more than others, thus reducing nur sinck on some kinds, and leavinz a sumply of other equally good kinds uncalled for. By the time the weather will permit sh pping orders in the spring. the surplus varieties will be apparent. Therefire, we have decided in make the following special offers of our over stock in the collections listed below. The choice of varieties must be left to us, but the qualiny of the plants and varieties will be just as good as though you ordered them at higher prices from our catalogue.

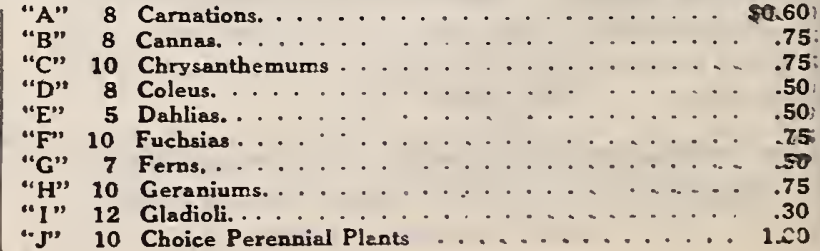



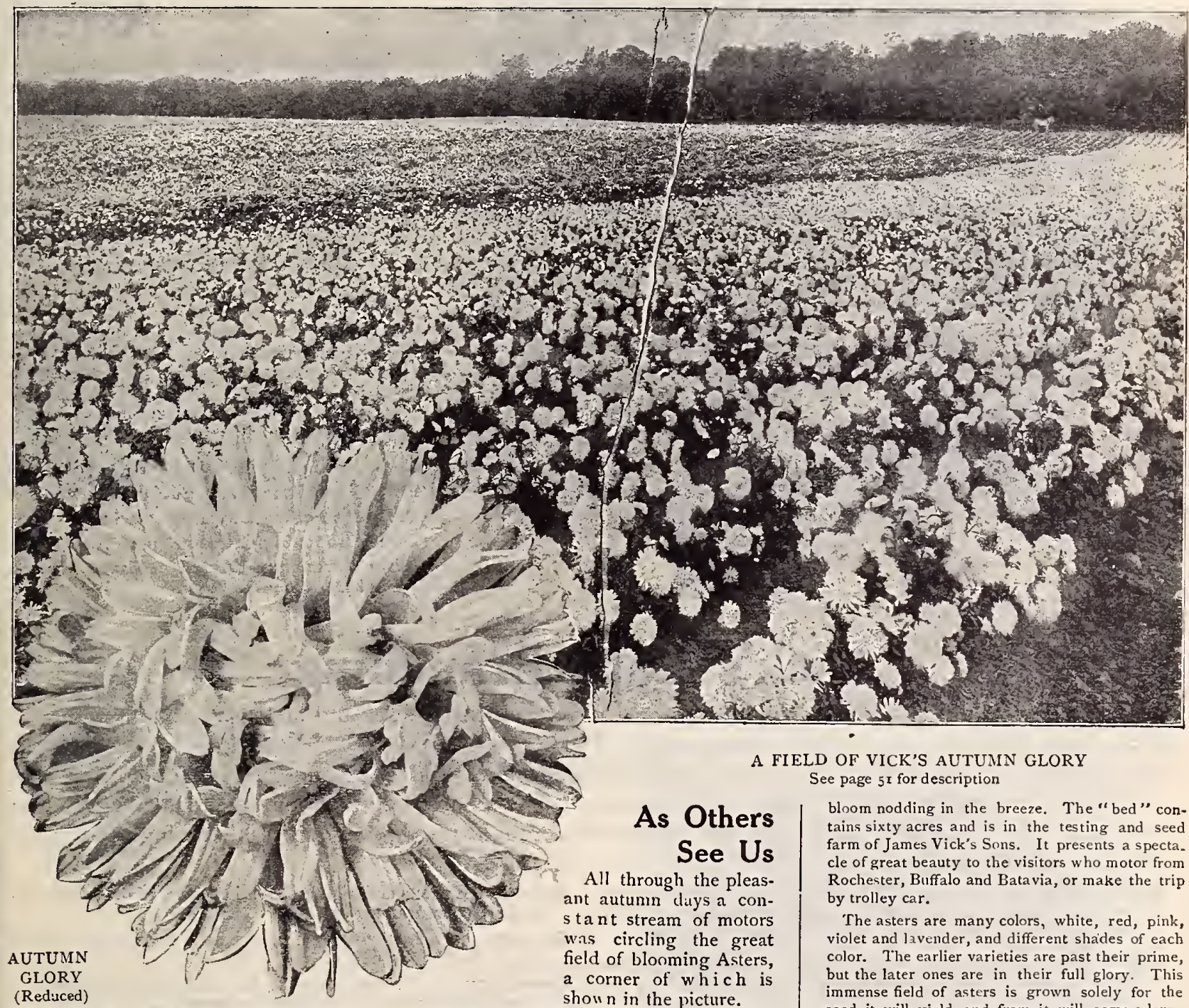

A FIELD OF VICK'S AUTUMN GLORY

From the New York World, October 5, IgI3 ROCHESTER, Sept. 27-The town of Ogden, in this (Monroe) county, boasts of what is said to be the largest flower bed in the world. It embraces sixty acres and is filled with just one variety of flower, the aster. There are millions of blossoms of dazzling white, red, deep purple, lavender, pink, crimson ard intermediate shades. It is a gorgeous spectacle, and daily automsbile parties run out from Rochester, Buffalo, Batavia and of ten from more distant points to see it.

From the."Florists' Review," September 25, Igr3

$$
\text { AT THE VICK SEED FARM }
$$

The members of the Rochester Florists' Association, their wives and friends, numbering about sixty in all, were entertained at the Vick seed farm, Friday, September ig, by James Vick's Sons. All present expressed the great pleasure it afforded them to see slich a nonderful spectacle. The farms of the seed firm contain 250 acres, and are in the town of 0 gden. A tract of sixty acres is devoted to the growing of asters, which are now in fiill blossom. Under special cultivation, this field is a mammoth expanse of white, red, purple, lavender and pink blooms. Millions of flowers are presented to the eye in a solid mass, appearing in the distance as a large carpet of color. The field of asters is circled by a driveway, so that visitors can eniny the display from every point of view. The memhers of the Florists' Association spent several hours examining the asters and were then entertained at luncheon by the firm.

From the Rochester Democrat and Chronlcle, Tuesday, Sept. 29th, 19:3

Out in the town of Ogden, close to the Barge canal, lies what is believed to be the largest flower bed in the world, with millions of asters in bloom nodding in the breeze. The "bed" contains sixty acres and is in the testing and seed farm of James Vick's Sons. It presents a specta. cle of great beauty to the visitors who motor from Rochester, Buffalo and Batavia, or make the trip by trolley car.

The asters are many colors, white, red, pink, violet and lavender, and different shades of each color. The earlier varieties are past their prime,
but the later ones are in their full glory. This immense field of asters is grown solely for the seed it will yield, and from it will come a large
part of the world's supply of aster seed for next year's gardens.

One large section is set aside for the cultivation of the Rochester Aster, which is a delicate pink shading to lavender. This is a new variety and was given the name Rochester at the request of the Chamber of Commerce. Other sections are given over to the cultivation of the Pink Enchantress, the Cardinal, Violet King, Peerless, and more than a hundred other variet]es,

The gathering of the aster heads for seed has been begun so far as some of the earlier varieties are concerned. Charles H. Vick, of the firm that conducts the farn of 250 acres, said yesterday : "We expect to get nearly a toll of aster seed from this farm this year." 


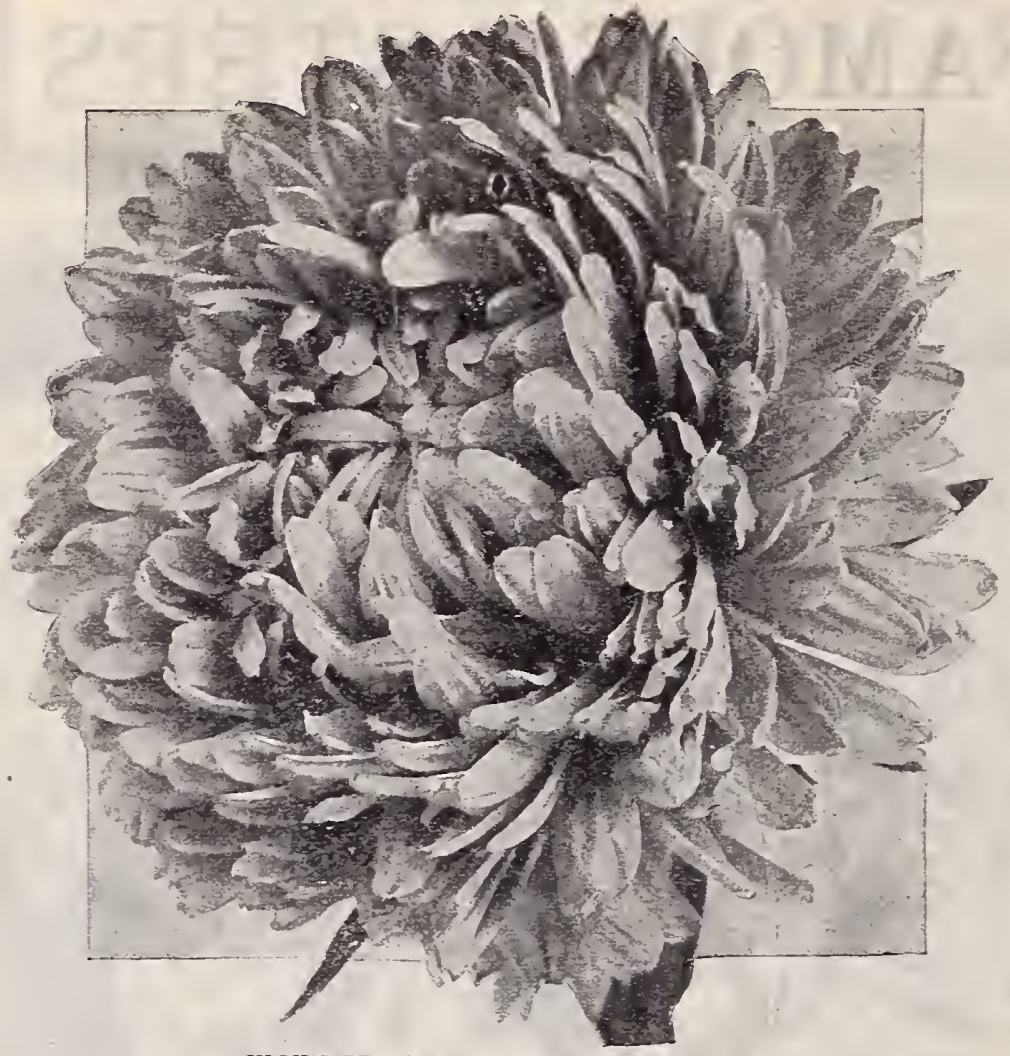

\section{Vick's \\ Branching Asters}

Vick's Branching Asters are known wherever Asters are grown. The plants are large and vigorous, the stems long and strong, and the great fluffy flowers, as we now grow them, are double to the center. There are other Asters, exquisite in form and delicate of color; but Vick's Branching Aster is still the leading Aster in all the Hower markets in the country and still hulds the first place in the garden of the amateur.

\section{Vick's Early Branching}

The plants of the Early Branching Aster attain the size and vigor of the famous Late Branching, but blossom from ten days to two weeks earlier. The few branches are free from sille buds, the whole strength of the plant being given to the development of extra large, perfectly forned fowers on long stiffstems, making them especially desirable for cutting, for exlibition, or for sale.

Early Branching White, packet ., to cents Early Branching Rose, packet. ... Io cents Early Branching Lavender, packet Io cents Early Branching Crimson, packet. Io cents. Early Branch ng Aster, Mixed colors. Packet, Io cents.

VICK'S BRANCHING ASTER

\section{Vick's Late Branching}

The flowers of the Late Branching Aster are of extraordinary size, and are borne on long, graceful stems from fifteen to twenty inches in length. The plants are extra large and of strong growth, one plant often covering a space of two and one-half feet square. They are unexcelled for cutting, and are by far the most satisfactory late Asters grown. The plants begin blooming about August 15 th and continue throughout the season, but they can be brought in to bloom earlier by sowing seed in the house in March or April.

Snow White. The latest of Branching Asters. Plants exceptionally strong and continuing to produce their great balls of white bloom until after a hard freeze. Packet, Io cents.

Vick's Pink. Opens nearly white, passing to a beautiful lavender pink, lighter in the center. Lasts particularly well as a cut flower. Packet, Io cents.

PEACH BLOSSOM. (New). A deeper shade of color than Vick's Pink, and one that is certain to become very popular. The large flowers are extremely double. Packet, Io cents.

Semple's Pink. An exquisite shade of light shell-pink. The large flowers are graceful in form. Packet, Io cents.

Peerless Pink. Might well be called an "Improved Semple Pink." It has the same delicate, pleasing shade of pink, and a more double flower. Packet, ro cents.

Deep Pink. The color of a deep pink Rose. Lighter than the Branching Rose. Beautiful, full double flowers, Packet, Io cts.

Rose. Large plants and big, full double flowtrs of rich, deep rose. Packet, io cents.

Crimson. A rich, glowing color, especially effective by artificial liglit. Packet, ro cents.

Rosy Carmine. Distinct, and beatiful-a bright rosy carmine. A lively brilliant color. Packet, Io cents.

Vick's Lavender. A good clear lavender. Soruetimes called azure blue. A splendid strain of this useful color. Packet, Io cts.

Semple-Lavender. An extremely pale shade of lavender. Packet, Io cents.

Purple. Beautifully formed, full double flowers of rich purple. Packet, Io cents.

Dark Violet. An extremely deep, glowing color. A deepe? shade than Branching Purple. It has a peculiar velvety tinish giving it an appearance of richness that is distinct and striking. Packet, Io cents.

CLARET. (New). A very deep reddish purple. An entirely new shade in the Branching class. Packet, ro cents.

Mixed colors. Packet, ro cents. For collection of eight varieties see page 44. 


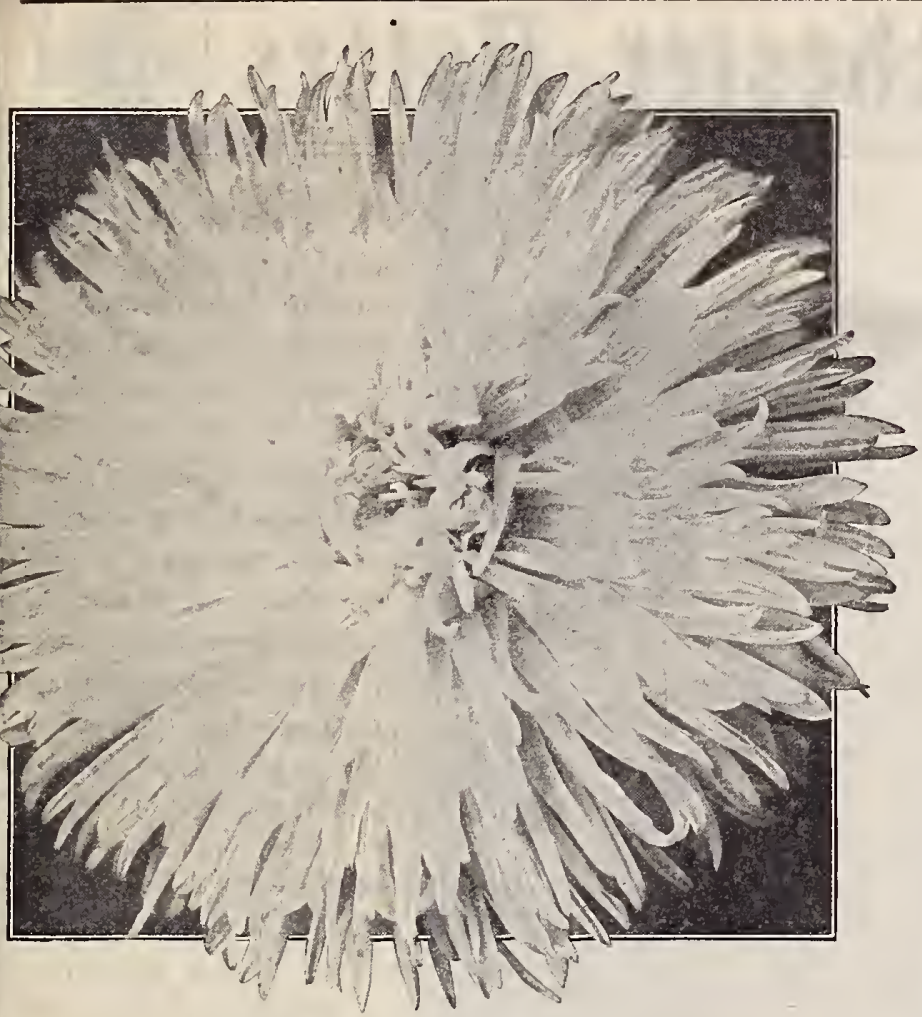

VICK'S WHITE KING ASTER

\section{Vick's Violet King}

Vick's Violet King blooms at the same time as Vick's Late Branching. The plants have a similar liabit of growth but the stems are exceptionally long and strong. The inmense flowers are a rich violet purple. The flower is quite thick, with a full center which is usually twisted into a strong "whorl" in the freshly opened flowers. The peculiar formation of the petal makes the flowers doubly effective in appearance. A vase of Violet King Asters is an object not only beautiful, but bold and striking. Packet, I5 cents.

\section{Vick's Rose King}

Vick's Rose King is a deep brilliant rose. It differs in color only from the now well known Violet King. Packet, I5 cents.

\section{Vick's White King}

The new White King has the same narrow petal as the older varieties, but the petal is not quite so strongly folded. This gives the flower a somewliat softer appearance. The cut flowers have the splendid lasting quality characteristic of the King class. In season, the White King blooms with the late branching, and has all the vigor of that famous class of Asters. The plants, however, are upright in growth, differing in this respect from the Violet King and the Rove King.

Packet, 20 cents; two for 35 cents.

\section{Vick's Pink King}

In color the New Pink King is a leautiful and delicate lavender-pink, very mucl like the now famou; "Rochester" Aster. It has the same type of flower and upright growth of plant as the White King. Packet, 20 cents ; two for 35 cents.

Vick's White, Pink, Rose and Violet King, Mixed, Packet, 20 cents.

\section{Vick's King Asters}

A magnificent class of Asters, distinct from all others in the character of the flower. The long, narrow petals are folded lengthwise, appearing almost as though quilled. The flowers are of great size and substance and last longer when cut than those of any other class. The plants are large and the stems exceptionally long and strong.

There are few Aster growers who do not know the Violet King, which we introduced in 1906. It has probably won more prizes in the last few years than any other variety in the world. In 1910 we introduced the Rose King, which at once became a great favorite. in 1912 we added two new and beautiful King Asters, differing from the Violet and Rose King not only in color, but in halsit of plant. This year we add another charming color, in both upright and branching plants to this list of novelties.

\section{Vick's Lavender King}

The massive flowers of the new Lavender King are of the same thick, fluffy type as those of the White King.

The color is a very pleasing shade of deep Lavender. We offer the Lavender with branching plants like those of the Violet King and Rose King; and upright plants like those of the White King and the Pink King. The two types are thoroughly fixed.

Lavender King. Branching type, pkt., 25 cents.

Lavender King. Upright type, pkt.,25 cents.

\section{Aster Plants}

We advise our friends that it is better and cheaper to grow their own Aster Plants than to procure them from a distance. For the accommodation of those who may be unable to grow plants themselves; and who wislı to be certain of having Vick's Asters, we offer, on page 53 , plants of twelve varieties.

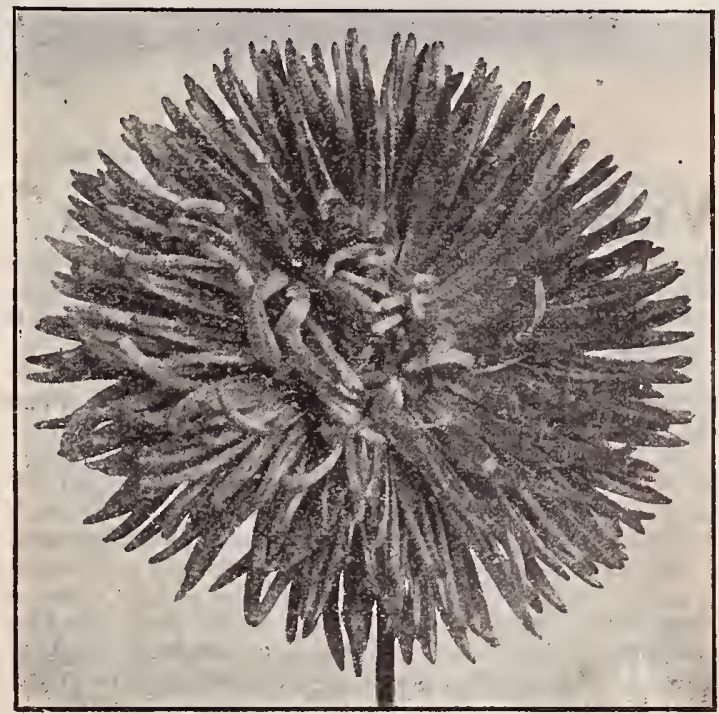

VICK'S VIOLET KING ASTER 


\section{Jick's Rochester Hsters}

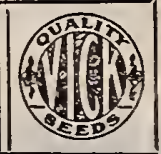

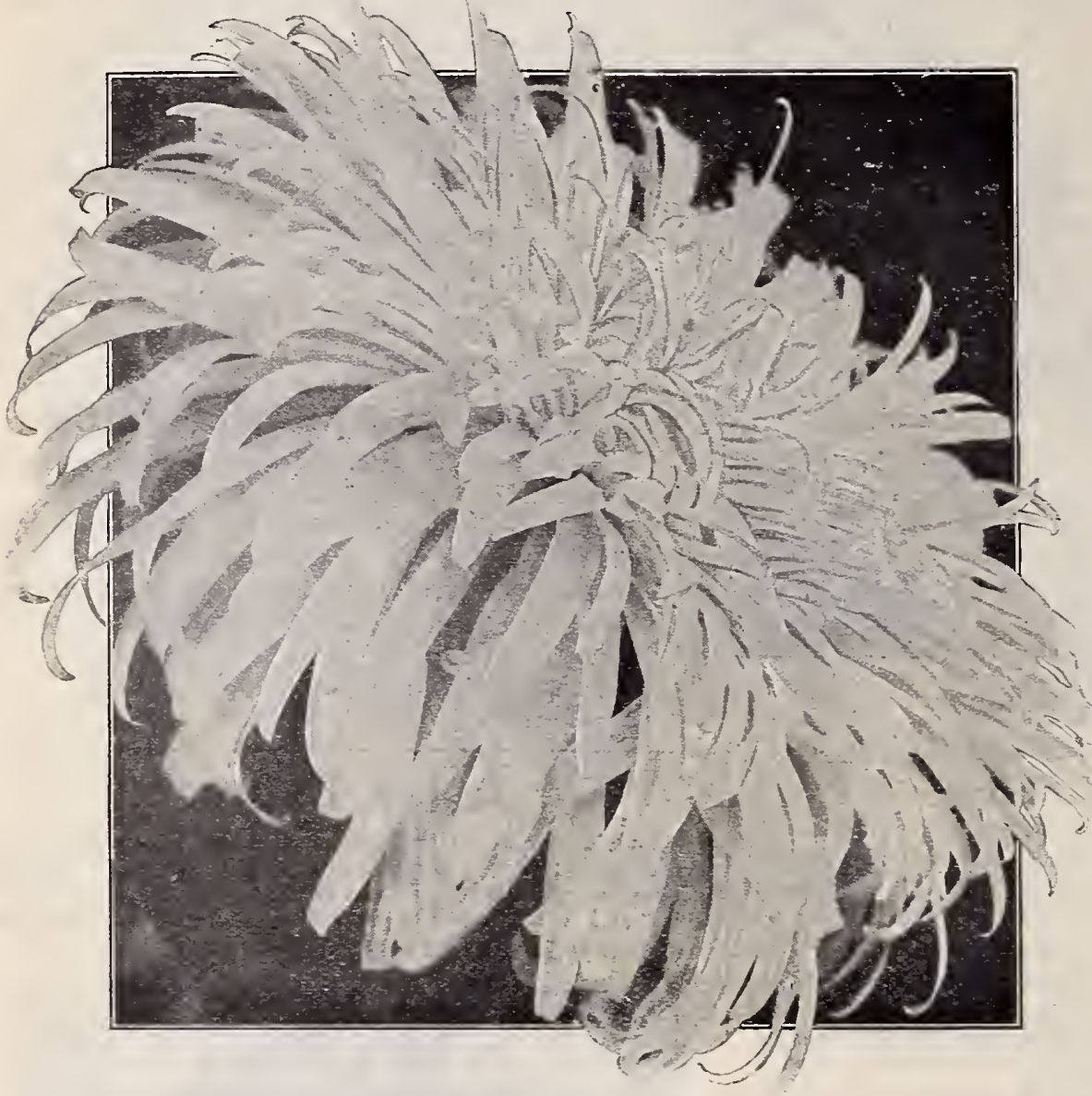

A New Class

We are proud of the city in which we live, and in which the house of Vick has been doing business for over sixty years. When we give the $\mathrm{n}$ ame "Rocliester" to a class of Asters it is because we have something that is the very best of its kind. The history of the original Rochester Aster is given below. We are now developing a Class of Asters wortlyy of this honored name. The plants are like those of the Late Branching, large and strong, with many long branches. The flowers, like all of the Comet type, have petals that are very long and narrow, and gracefully recurved, giving them a lightness and grace that makes them the most artistic of all Asters. The immense size of the flowers-they are the largest Asters now in cultivation-their artistic beauty, their delicacy of coloring and freedom of bloom make them, in our estimation, superior to any Asters heretofore offered.

\section{Vick's Pink "Rochester"}

No flower introduced in recent years has created such a furor as this magnificent Vick's Milsado Pink Aster, “ Rochester." Within a year after we first presented it to the public, the Chamber of Commerce of Rochester recommended that it be adopted as the official flower of the city and requested Mr. Vick to rename it "Kochester." The "Rochester" Aster is today the Premier of the Lavender-Pink Asters. Like all the flowers of the Comet class, the petals of the "Rochester" are narrow, very long and gracefully reflexed. The outer petals show to their full extent, while gradually toward the center they bend and curl across each uther in such magnificient disorder, as to milke the fluffiest Aster we have ever seen. In color it is a most exquisite shade of lavenderpink, leing a happy medium between the color of Vick's Branching Pink and Vick's Daylureak. For a mid-senson pink this Aster is without a rival. In season it is a little linter than the White Mikado. The plants are unusually vigorous and it is not uncommon to find one with a dozen long, strong, graceful stems, each crowded with flowers from four and a half to six inches in diameter.

Packet I5 cents.

\section{Non-Lateral Rochester Lavender Pink}

The flowers are borne stiffly erect and are more double than those of the original Rochester, while the color is the same charming shade of lavender pink. The flowers of the Non-lateral Rochester not only have the great size of those on the branching plant, but they have a remarkable thickness and are without any trace of a center. The entire strength of the plant is given to the production of six or eight immense, wonderfully doulble flowers, which are held erect at all times by the stiff, semi-upright stems. Alout one week earlier than the rriginal, or branching type of Rochester.

Packet, 25 cents; two for 40 cents. 


\section{Vick's}

Lavender

and Purple Rochesters

It is no exaggeration to say that these marvelous Asters are far in advance of any heretofore offered.

Vick's Lavender Rochester and Vick's Purple Rochester are new colors in this splendid type of Aster and they are even larger, more double and more chrysantliemum-like than the original Pink Rochester. A correspondent of IJorticulture, the leading Horticul. tural magazine of New England, visited our seed farms in the season of Igra. In the issue of October 26th, referring to the new lavender and pur. ple Rochesters, he says: "There were flowers in Vick's trials this summer like perfect in. curved Chrysanthemums, and a ct ually larger and more double than the early Chrysanthemums."

The illustration fails to show the wonderful thickness of these great masses of shaggy petals. The stout stems are few in number and mostly without side branches.

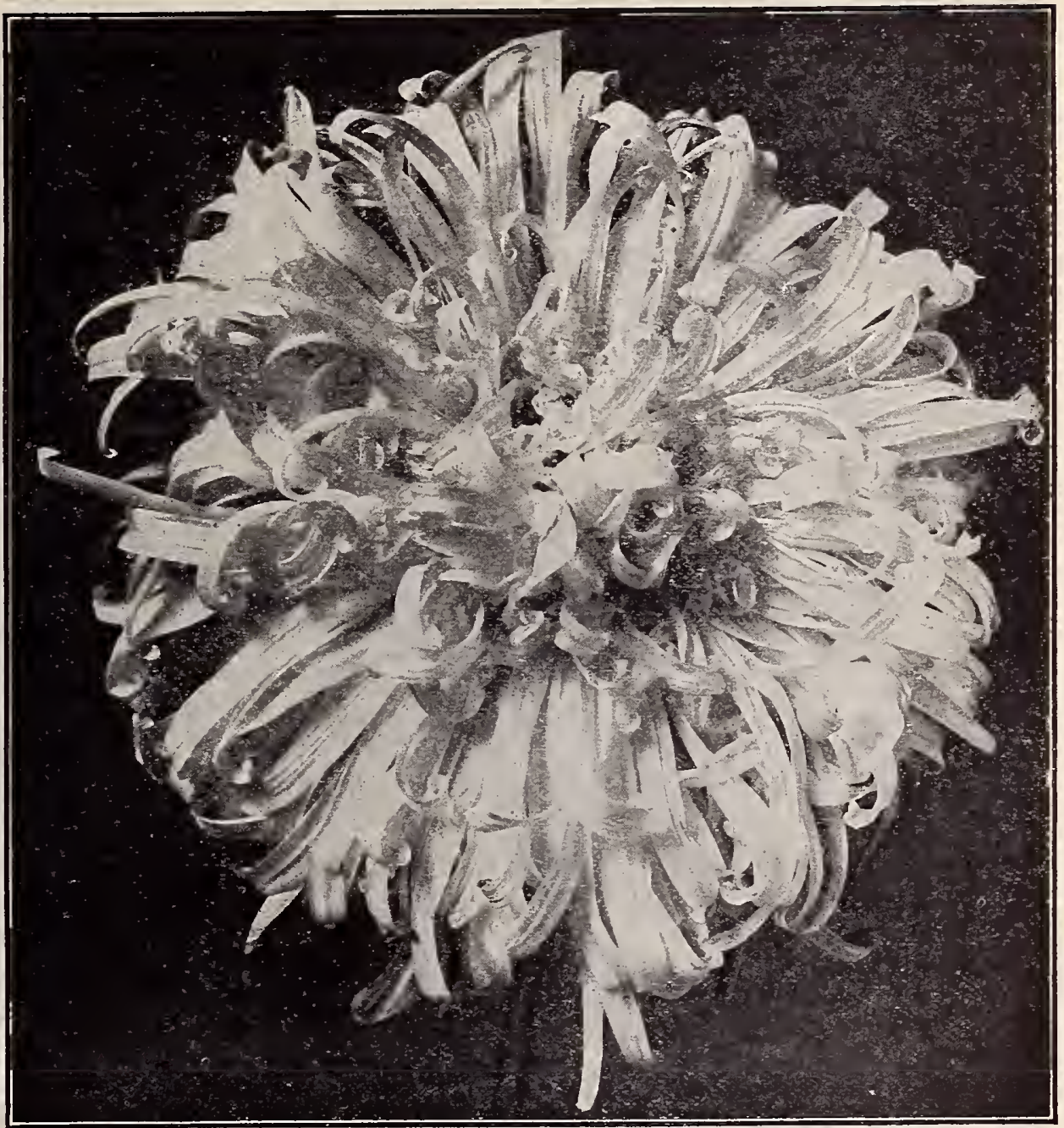

Vick's Lavender Rochester. A clear light lavender color; just the shade in greatest demand by the florists.

Packet, 25 cents ; two for 40 cents.

Vick's Purple Rochester. A deep rich purple.

Packet, 25 cents; two for 40 cents.

Vick's Upright Rochester. Identical in color and formation of flower with the original Lavender Pink Rochester, but strong, upright plants. The large, full double flowers, a little smaller than those of the branching Rochester, are borne in great profusion on long slender stems. A row of the Upright Rochester in bloom is a solid bank of pink. Packet, 20 cents; two for 35 cents.

\section{Crego Pink Aster}

The Crego Pink is a large Comet Aster with the beautiful shellpink color of Semple Pink Branching, but a trifle lighter in shade. The plant has the size and the habit of the Branching Asters. It blooms after Vick's Rochester, and before the Branching varieties. Packet, ro cents.
VICK'S LAVENDER ROCHESTER

\section{Vick's Mikado Asters}

Vick's White Mikado, was the forerunner of this beautiful group of Comet Asters The great shaggy, white flowers are made up of petals that are curled and twisted so that the flowers resemble fine white Chrysanthemums. The flowers are carried on stems of good length. The plants have a spreading habit, similar to that of the Branching Asters. The White Mikado is among the earliest of the mid-season Asters, coming immediately after the extra early varieties. Packet, 25 cents.

Vick's Rose Mikado. A deep, brilliant rose color. Like the White Mikado except in color. Packet, 15 cents.

Vick's Dark Violet Mikado. A rich, deep purple violet. · The flowers are full double, very decorative in character and borne on good, stout stems. Packet, 15 cents.

\section{Late White Mikado, or Hohenzollern}

Immense, pure white flowers, like great ragged Chrysanthemums, blooming at the same time as the Late Branching Asters. It is, in effect, a Comet flower on a Late Branching plant. Packet, 15 cents. 


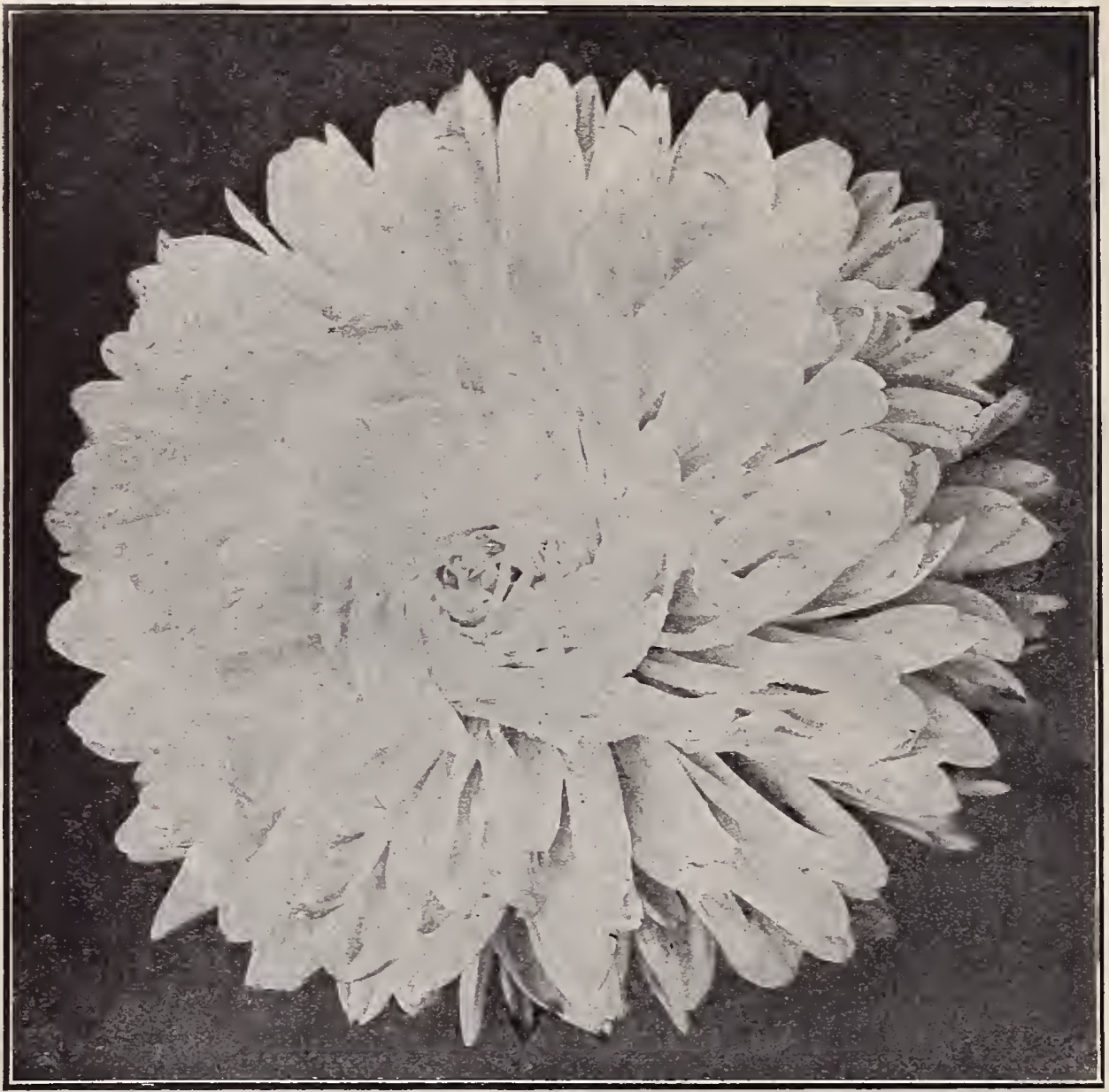

Scarlet Bedding Asters

\section{VICK'S}

\section{SCARLET GEM}

Scarlet Gem is the nearest approach to a true scarlct color that has so far been produced in Asters. The plants are of the Brancling type. The flowers are larger than those of the Cardinal, a brighter, more fiery color, and not quite so double.

Packet, 20 cents.

\section{VICK'S NEW CARDINAL}

The best bedding Aster ever introduced. It has a very long season of bloom. The buds are a rosy carmine ; the fully open flowers, which develop quite slowly, are a brilliant glowing cardinal, gradually fading to a deep crimson. The whole plant has a dark, rich color; even the dry and withered flowers retain so much color that the plant does not become unsightly. In the new strain of Cardinal now offered the middle of the flower is filled with long quill-like florets, so that it never shows a yellow center.

Packet, 20 cents.

VICK'S PERFECTION ASTER

\section{VICK'S PERFECTION ASTERS}

\section{WHITE PERFECTION}

We consider this the finest mid-season White Aster in cultivation. Grown under ordinary farm conditions, the flowers averaged four inches in diameter. They are exquisite in form, and the plants are taller than those of the late upriglit Asters. When first opened the entire flower is strongly whorled, producing a charming effect. The broad petals are slightly folded lengthwise, making them appear rather narrow. In mature flowers, the outer rows of petals are straight, but the center still retains its characteristic strong whorl. The plants are extremely vigorous, with unusally broad dark green leaves and stout stems. They carry about twelve large flowers on long stems free from side branches.

Packet, 20 cents; two for 35 cents.

\section{BLUSH PERFECTION}

An exquisitely dainty companion to the White Perfection. The flowers are equally large and have the same beautiful whorled form, but the color, instead of being snowy white, is an extremely delicate shade of flesh pink. The plants are similar in height, season of bloom and number of flowers, hut the Blush Perfecion makes a more slender growth. Packet, 20 cents ; two for 35 cents.

\section{SHELL-PINK PERFECTION (New)}

Like the Blush Perfection, introduced last year, the new Shell Pink Perfection makes a tall, slender growth. The large, very double flowers are borne on stems of great length, making them especially valuable for cutting. The color is a beautiful shell pink, distinctly deeper in shade than Blush Perfection. In the fully opened flower the outer petals are widely spread, while the center of the flower is strongly whorled and the petals are also incurved.

Packet, 25 cents; two for 40 cents.

\section{ROSE PERFECTION (New)}

The flowers of the Rose Perfection are a deep, bright rose color. They are of the same strongly whorled, incurved type as those of the Blush and Shell Pink Perfection; and the plants also have the same tall, slender, long stemmed habit. Many of our New York State friends will recall seeing in our exhibit at the I913 State Fair a vase of these bentiful, bright rose-colorcd flowers, with a pronounced twist to the petals. Packet; 25 cents; two for $40 \mathrm{Cus}$. 


\section{Vick's Pink \\ Enchantress}

\section{Aster}

This splendid Aster introduced by us in I 9 I 2 , was highly commended by our customers, and large quantities will be grown the coming season by commercial florists. The immense flowers of a soft, delicate pink, are borne on strong, upright plants. The color is that of the popular "Pink Enchantress" Carnation. In Asters the color is between that of Vick's Daybreak and the Seinple's Pink Branching. This color, although very delicate, does not fade. The plants are tall and strong and the flowers are the size of those of the largest Branching Asters. The flower is made up of broad petals, loosely arranged, and the effect is indescribably soft and pleasing. Nothing could excel in refined beauty a vase of Vick's Pink Enchantress Asters.

Packet, 20 cents ; two for 35 cents.

\section{Vick's Autumn Glory}

\section{A New, Very Late Branching Aster}

\section{ILLUSTRATION ON FRONT COVER}

Pure sea-shell pink. While similar in color to Semple's Pink, with which most growers are familiar, it has a better and more substantial flower, a deeper and longer-keeping color, and larger and stronger type of plant. Its most distinctive characteristic and chief claim for recognition, however, is the fact that it is later in season than any of the other varieties. While it cannot take the place of others of similar color, which are earlier, it supplements them by blouming after the other Late Asters are past their prime, and before the early Chrysanthemums are ready, thus prolonging the Aster season two weeks, and coming at a time, when good flowers are extremely scarce. Vick's Autumn Glory will be a money-maker for the commercial grower, and a delight to the amateur. It comes uniformly true to color and type. The flowers are very double and are borne on stems of unusual length. Packet, 25 cents; two for 40 cents.
VICK'S PINK ENCHANTRESS

\section{Triumph Comet}

\section{ILLUSTRATION ON PAGE 4}

A magnificent new class of mid season Asters, with extra long stems and large, fluffy, full double flowers of the finest type. Splendid Mikado or Rochester flowers of the best type, on tall, upright plants.

We offer five colors this ycar: White, Shell Pink, Lavender, Rose and Purple.

Packet, 25 cents; two packets of one variety for 40 cents. The set of five colors, $\$ 1.00$.

\section{Vick's Lavender Gem}

When first open the flower is an exquisite pale lavender, deepening with age. The flower is always full double, and it bears a large proportion of long, partly tubular florets, which are irregularly cut and slashed, so that it looks like a ragged Chrysanthemum. The flowers are borne in profusion on long, slender, wiry stems. The plant is erect and of mediun height, branching close to the ground. It is classed with the early sorts. Packet, 20 cents. 


\section{VICK'S IMPERIAL ASTERS}

The Imperial Asters comprise a collection of mid-season varieties distinguished by their delicacy of coloring, their profusion of bloom and the extreme doubleness of their flowers. The vigorous plants are upright in growth and produce stems of good length. The large flowers are so double as to be veritable balls of bloom. In most of the Imperial varieties the petals are narrow, straight, and sometimes slightly folded lengthwise. Vick's Daybreak, introduced by us in 1897 , and Vick's Purity introduced in 1899 are now the best known and most widely used of all nidseason Asters.

\section{Imperial Giant Daybreak}

The fully double, perfectly formed flowers are a beautiful and extremely delicate shade of flesh pink.

Packet, is cents

\section{Imperial Giant Purity}

Larger in plant and flower than the famous original. Crowned with great snow white globes of bloom.

Packet, 15 cents.

\section{Imperial Lavender}

A delicate shade of palest lavender. Resembles Daybreak in size, in form and in season. The lavender tint is about the same depth of color as the pink of Daybreak. Packet, 5 cents.

\section{Imperial Rose}

A very attractive shade of silvery rose. The blooming plants are veritable boquets of roses.

Packet, 15 cents.

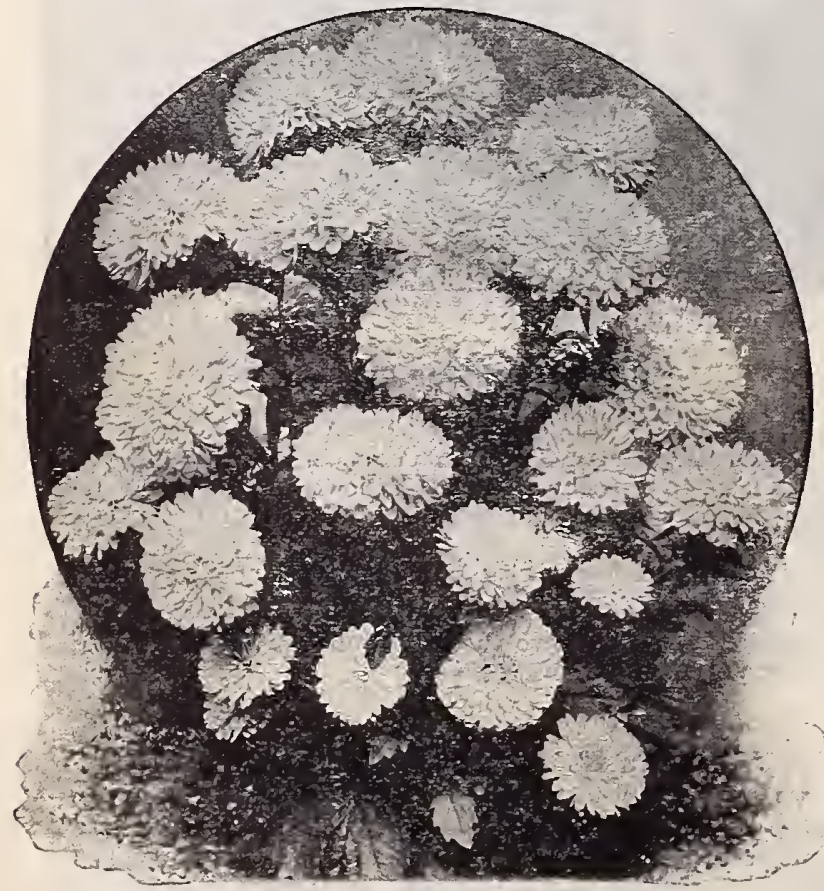

PLANT OF VICK'S IMPERIAL LAVENDEK ASIEK

Imperial Collection of ten separate varieties, $\$ 1.25$.

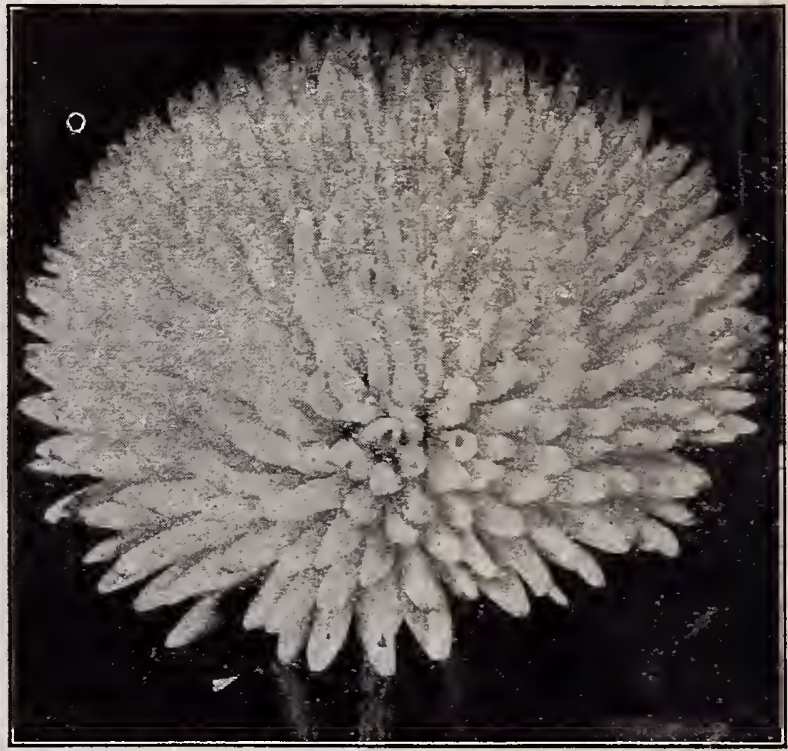

VICK'S IMPERIAL SUNRISE ASTER

\section{Imperial Sunrise}

The large, globular flowers are a little deeper shade of pink than Daybreak. The soft clear coloring of the slender needles, shading delicately to the center, is exquisitely dainty. Packet, 20 cents.

\section{Imperial Bluebird}

A bright, lively blue. The plants are covered with the roundecl, full double flowers.

Packet, 15 cents.

\section{Imperial Violet}

A rich, dark violet purple. The large flowers contrast well with the delicate pinks of the Inperial class.

Packet, 15 cents.

\section{Imperial Sunset}

A delicate tint of creamy pink shading to a deeper pink at the center. The dainty coloring is unusual in Asters. Packet, 15 cents.

\section{Imperial Salmon}

A new color in Asters, A pale shade of pinkish salmon. The freshly opened flowers are a most exquisite color. Packet, 5 cents.

\section{Imperial Yellow}

A pale lemon yellow, flushed with pink. The flowers of Imperial Yellow and Imperial Salmon are not so large as those of some of the Imperials; but they make up in rare and dainty coloring what they lack in size.

Packet, 15 cents. 


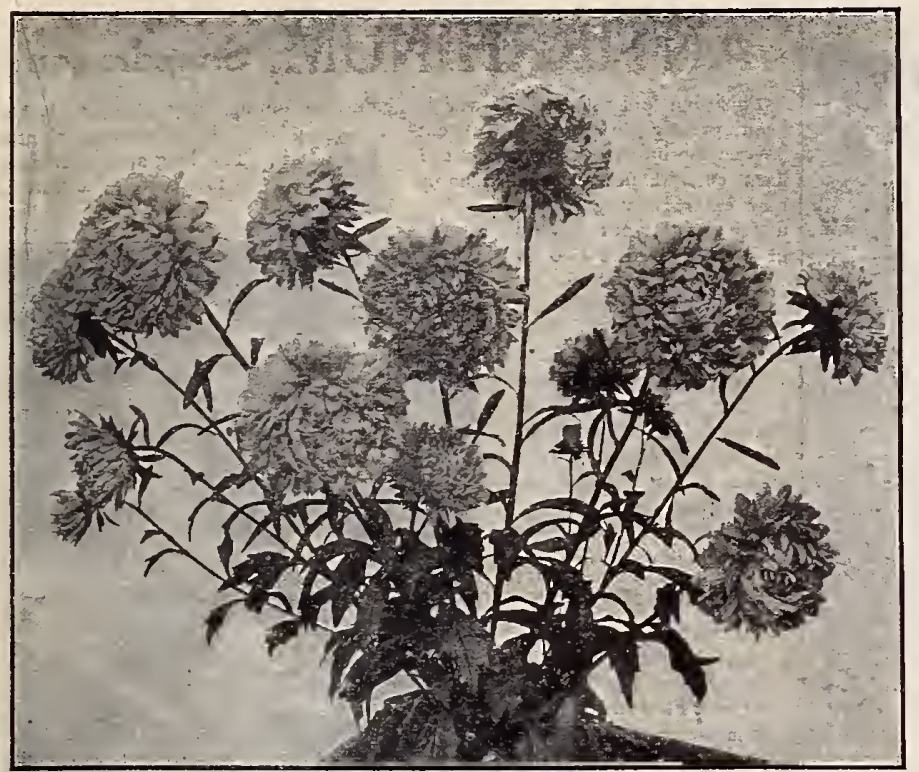

VICK'S ROYAL ASTER

\section{VICK'S ROYAL ASTERS}

A new class of Asters in which the petals are very broad and distinctly incurved or shell-shaped. The peculiar shape of the petal gives an effect of shading that enhances the beauty of the color. The flower has a charming grace and a Chrysanthemumlike effect. In size the flowers are like the Late Branching Asters, and the plants have the same sturdy vigor but are not so tall, as they branch close to the ground. In season they are earlier than the Branching Asters, remaining in bloom a long time.

Vick's Royal White. Vick's Royal Lavender.

Vick's Royal Shell Pink. Vick's Royal Purple,

Separate colors or mixed colors, each, Packet, I5 cents.

\section{QUEEN OF THE MARKET}

Largely grown by commercial florists for cut flowers alid for early market. The plants have an open, spreading habit, and the large, double flowers have a loose and graceful appearance. Seed should be sown quite early in the honse.
- White, Pink, Rose, Dark Blue,
Crimson, Scarlet, Lavender, Light Blue.

Separate Colors, or mixed colors, each, Packet yo cents.

\section{VICTORIA}

Pkt.

Two feet high; habit, pyramidal; flowers, large ; an old standard variety, having a great range of colors. Mixed colors Io

\section{TRUFFAUT or PEONY FLOWERED}

The double flowers have the petals incurved, like a Peony. Two feet. Mixed colors............... Io

\section{QUILLED GERMAN}

A showy class, from one and a half to two feet high, with quilled flowers and branching habit. Mixed colors.

\section{MIXED ASTERS}

All classes and colors mixed in great variety . . . . 5

How to Grow Asters, Their Culture and Care.

Newly revised, enlarged and illustrated. Contains many new points of value, and is a practical instructor for the Aster grower. Free with an order for Vick's Aster Seed amounting to 25 cents, or sent postpaid on receipt of ro cents without order for seed.

\section{ASTER PLANTS}

Strong, well-grown plants, that have been hardened off ready for setting out, of the varieties named below : Plants will be ready for delivery about May $\mathbf{1 5}$.

Only the twelve varieties named below can be supplied in plants :

Vick's Late Branching. White, Pink, Lavender and Purple.

Vick's King Asters. White, Fink, Rose and Violet.

Vick's Rochester and Mikado. White, Pink, Lavender and Purple.

One dozen, one variety, 30 cents, postpaid

Ono Hundred, one variety, $\$ 1.25$, not prepaid COLLECTIONS

One dozen, not less than 3 of one variety, 35 cents, postpaid Two

Three 60

One Hundred, not less than 10 of one variety, $\$ 1.50$, not prepaid

\section{Vick's Late Upright}

A new strain of Asters combining the upright growth of the earlier varieties with the flowers, the season and the foliage of the Late Branching. The upright habit adnits of closer planting and the blooms are less likely to be soiled by storms.

Late Upright White, Rose, Purple and Peachblossom.

Vick's Late Upright Pink. Beautiful shade of lavender pink. The very full center remains white for a long time.

Vick's Late Upright Crimson. A deep, rich, glowing color and very large flowers.

Vicks Late Upright Amethyst. The flowers open nearly white, deepening with age to a decided amethyst.

Separate colors or mixed colors, each, packet, 15 cents.

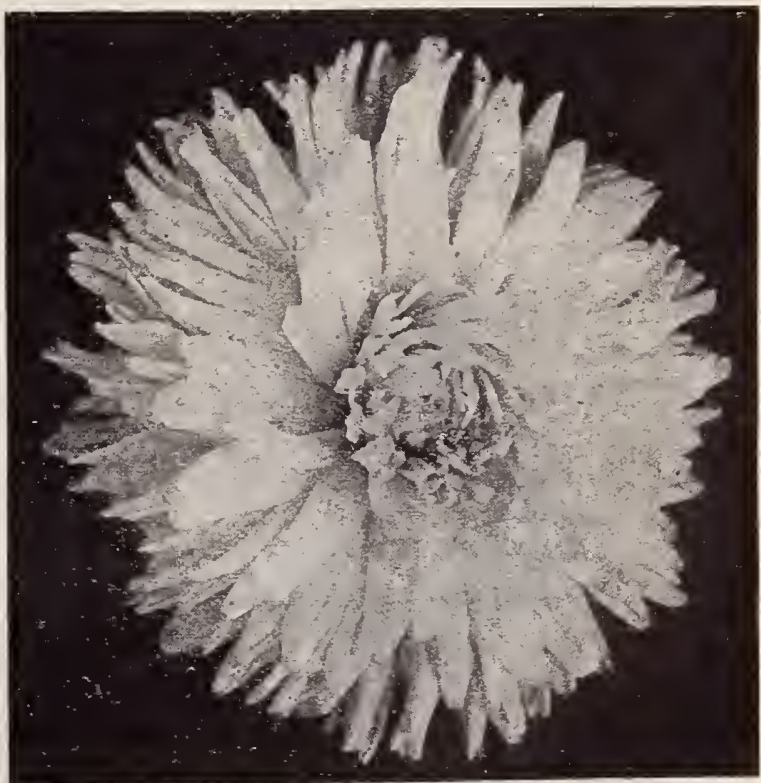

YICK'S LATE UPRIGHT PINK. 


\section{AGERATUM}

Tbe pretty brush-like flowers of the Ageratum are produced in clusters constantly all througb the summer. The plant has a neat, bushr habit. Excel lent for bedding or for bouquets. Seeds may be sown in a mellow seedbed in the open ground, or under glass early in the season. Anuual. Grandiflorum album, Wbite. Large flowers. Medium height..... 5 Little Dorrit. Azure blue. Very dwarf. Free flowering. . . . . . . 5 Little Dorrit, White. Same as above, except in color of flower

Blue Perfection. Splendid dwarf bedding variety, tbe darkest of all blue Ageratums. $1 / 4$ ounce, 25 cents

Princess Victoria Louise. Dwarf. Brigbt blue, white center

Mixed varieties. Ounce, 30 cents

\section{ALLEGHENY VINE}

Adlumia cirrhosa. Wood Fringe. Graceful hardy climber with feathery toliags like the Maiden Hair Fern. Bears a profusion of pretty and curious pink flowers. Easily grown and blooms first year from seed . .

\section{ALYSSUM}

Small white flowers, delicately fragrant, valuable for cutting and for bedding Sow in early spring or even the previous antumn. In the border the plant is covered with bloom the entire season. For winter bloom sow the last of All gust, thimning to about a dozen plants for a good sized pot or basket. Whei out of bloom cut back for a second crop of flowers.

\section{ANNUAL}

Sweet Alyssum, Ounce, 25 cents.

Little Gem. Dwarf, compact. Not over six incbes high. Covered with fragrant wbite flowers the entire summer. Ounce, 40 cents

Carpet of Snow. As the name indicates, this variety forms a close mat completely covering the ground witl white bluom. Ounce, 40 cents

\section{PERENNIAL}

Gold Dust Alyssum saxatile compactum. Hardy, compact growth, producing a mass of golden yellow flowers in early spring. Of easy culture and inuch used iu rockeries. Ounce, 25 cents

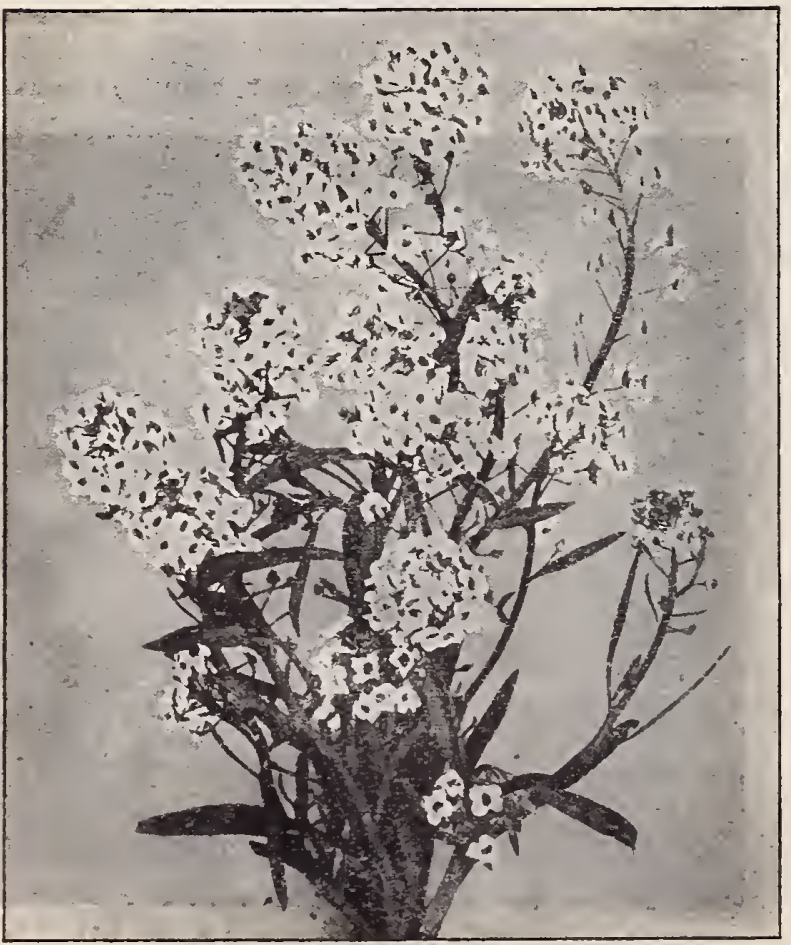

SWEET ALYSSIIM

\section{ANTIRRHINUM, Snapdragon}

This fine old-fashioned flower is again becoming very popular. It bas been greatly improved in recent years. As a bedding plant it blooms continuously until late in the fall. The long spikes of brilliant colored flowers are valuable now extensively grow n under glass for cut flowers in winter. Grows two to three feet high. Sown in early spring it blooms freely the first season. For early flowers sow seed in midsummer and protect the young plants over winter. Plants from seed sown in the spring will live over winter if not allowed to bloom much the first year. They should have some protection in winter:

Purple King, New.

The first of a new class of Snapdragons. M u c h larger than the present "Giant Flowered." The immense flowers of Purple King are a deep, glowing purple. Splendid for decorative purpose.

Packet, 20 cents.

New Giant-Flowered. Fine flowers, double the size of ordinary sorts, of a rich velvety texture.

Bright Crimson; Brilliant; Chamois; Deep Scarlet: Firefly; Galathe; Yellow; Rose; Striped; White. each. ..... to Collection of eight varieties in separate packets 50 cents, postpaid.

Extra Fine Giant. - flowered Mixed.

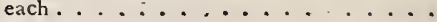

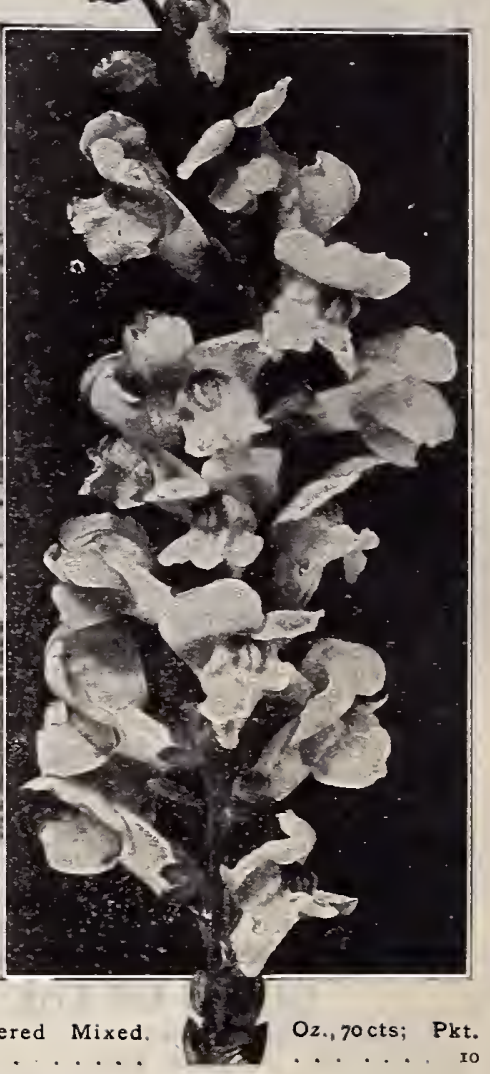

Fine Mixed. Ounce, so cents; each.

Queen Victoria. Very large, pure white, superb

\section{AMARANTUS}

Bright colored plants from three to five feet high. Easily grown annuals Sunrise. The most brilliantly' colored of the Amarantus. Lower leaves dark maroon; top of plant glowing crimsoll scarlet.

All Varieties, Mixed

\section{ANCHUSA}

Anchusa Italica, Dropmore variety. One of the most valuable of the recent introductions 11 bardy plants. Tbe plants are very vigorous, the rough leaved stems growing to a height of five feet. The flowers are a beautiful, clear, bright blue and are freely; produced all summer; making a most striking plant in the hardy border..........

\section{ANTHEMIS}

Tinctoria. Golden Marguerite. Pretty, hardy plant with finely divided leaves, growing to a height of two or theee feet. liears, throughout the summer, an abundance of long-stemmed, golden yellow, Daisy-like flowers. Excellent for cutting. One-quarter ounce 25 cents . . .

\section{ASPERULA}

Fragrant, profuse, blooming plants about nine inches in height. Thrive well in shade.

Odorata. Sweet Woodruff. Perennial, The white flowers delightfully fragrant, and the dried plant is often preserved for its perfume ..... xo Azurea setosa. Annual. Fragrant sky-blue flowers. Blooms all suminer 5 


\section{AQUILEGIA, Columbine}

One of the most beautiful of the hardy perennial plants. The graceful and peculiarly shaped flowers are borne on slender stems well above the bandsome foliage. Plants grow two to three feet high. Seed sowed any time up to mid. summer will produce plants that will begin to bloom the following May. P'erfectly hardy and of easy culture.

Pkt.

Canadensis, Our native scarlet and yellow Columbine

Carnation or Striped. Wbite, with red stripes; double. Fighteen incbes ro Glandulosa major. Dark blue, very fine.

Glandulosa vera. Large, erect, dark hlue flowers; pure white corolla Nivea grandiflora. Large white, semi-double flowers

Mixed varieties, single or double, eacb .

LARGE FLOWERED VARIETIES WITH LONG SPURS

Chrysantha. Beautiful canary jellow from New Mexico and Arizona. Tbree feet.

Cœrulea, Rocky Mountain Columbine. Sky blue and white. Superh Skinneri. Yellow; with scarlet spurs; the sepals greenisb orange. Peau New Large Flowering Hybrids. Many beautiful shades. Long spurred, large flowers.

\section{BALSAM,}

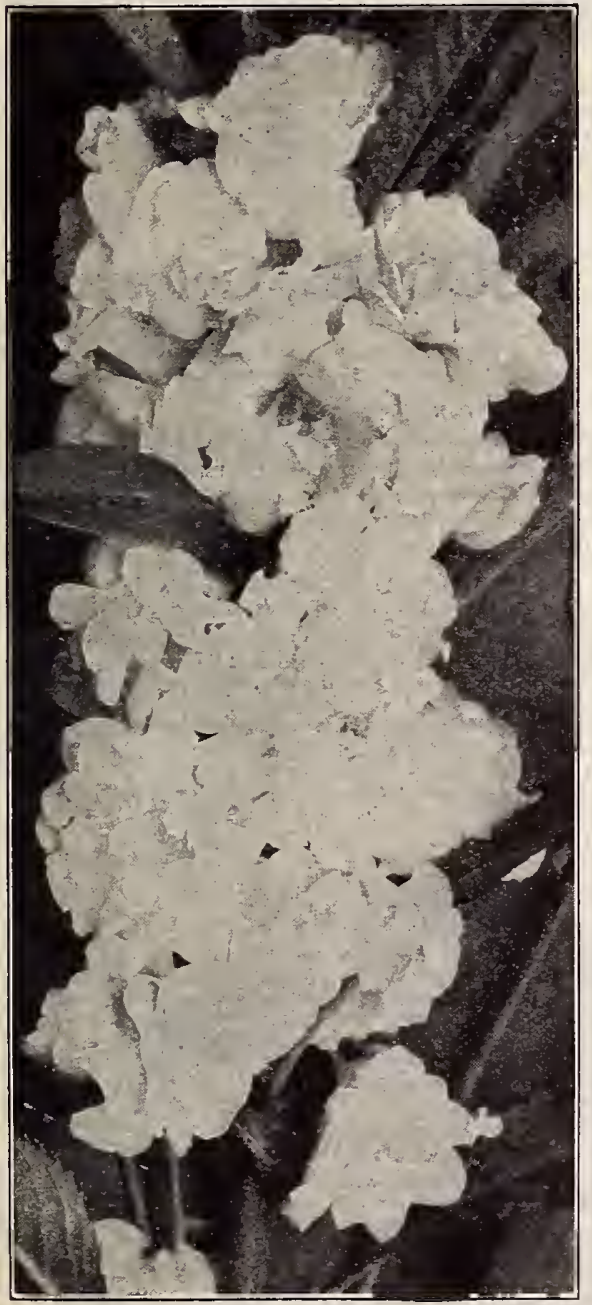

BALSAM

\section{LADY'S} SLIPPER

The seed of this popular old fashioned annual should be sown eitber in the house, or in the garden after the ground ground has become warm. They do best in a rather light soil. The plants transplant readily and the flow. ers are much finer if the plants have plenty of room; one foot apart each way is not too much space forbest results. Grown iu this way and given plenty of water the Balsam will make a splendid show and will remain in bloom for a long time. Tbe plants grow about two feet in beight.

Camellia - flow-

e red. Superb

double flowers

in a variety of

colors. Pkt.

White ..... IO

Deep Blood Red Io Spotted ..... I0 Striped . ... I0 Mixed. Many fine shades . . 10 Common Double A great variety of colors. Flowers not so uniformly double as the Camellia Flowered.

Ounce. $50 \mathrm{cts}$... 10

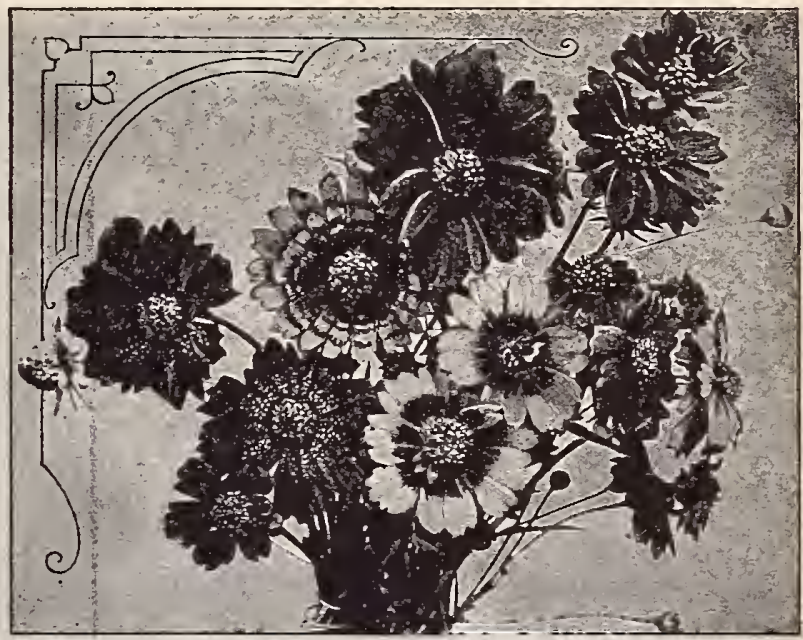

ANNUAL CALLIOPSIS

\section{CALLIOPSIS}

Plants about two feet in height, of slender growth, and should be given plenty of room to spread. The flowers are of various shades of yellow and orange, variegated with rich velvety crimson or maroon. These graceful flowers are excellent for bouquets, their warm and brilliant tints harmenizing well with all other colors. The seed grows very readily, ard may be sown where the plants are to flower. Annual. Pkt.

Coronata. Plants compact and of a bright rich green. Bloom early and continue until late fall. Flowers golden yellow, about the size of a silver dollar

Drummondi (Golden Wave). Plantsbushy, compact, covered with rich golden yellow flowers, chestmut-brown center

Dwarf Varieties Mixed. Fine for edging or pots

Tall Varieties Mixed

\section{COREOPSIS}

One of the best hardy perennials Used extensively for cut flowers. Very free-flowering, blooming from June to October. The large, showy, golden yellow flowers are borne on long stems, and will last a week or more when cut, making them very desirable for that purpose. Fasily grown trom seed, and will bloom the first year if seed is sown early.

Grandiflora lanceolata. Will grow anywhere. Two to three feet. Io

\section{CHRYSANTHEMUMS}

The Annual Chrysantbemums are free-blooming, easily grown plants. The Single varieties have large, Daisy.like flowers in a variety of brilliant colors and are fine for cutting.

\section{ANNUAL VARIETIES} varieties. Mlixed colors Double White, Double Yellow, and Double Mixed, each.

\section{PERENNIAL}

Marguerite, or Paris Daisy. Elegant bushy plant, one to two feet high. Blooms all summer in the garden, and fine for winter flowering. Flowers white, star-shaped.,

\section{AFRICAN DAISY}

See page 5 for illustration.

New Hybrids. The blooms of these new Hybrids of the Golden Orange African Daisy, Dimorphotheca aurantiaca, comprise a wonderful variety of beautiful and delicate shades of color, ranging from pure white through pale salmon and primrose tones to deepest orange. The flowers are very graceful and are produced in the greatest profusion all summer. $A$ bed of the New Hybrid African Daisy makes a continuols and charming display of color. Packet ...................... I5 


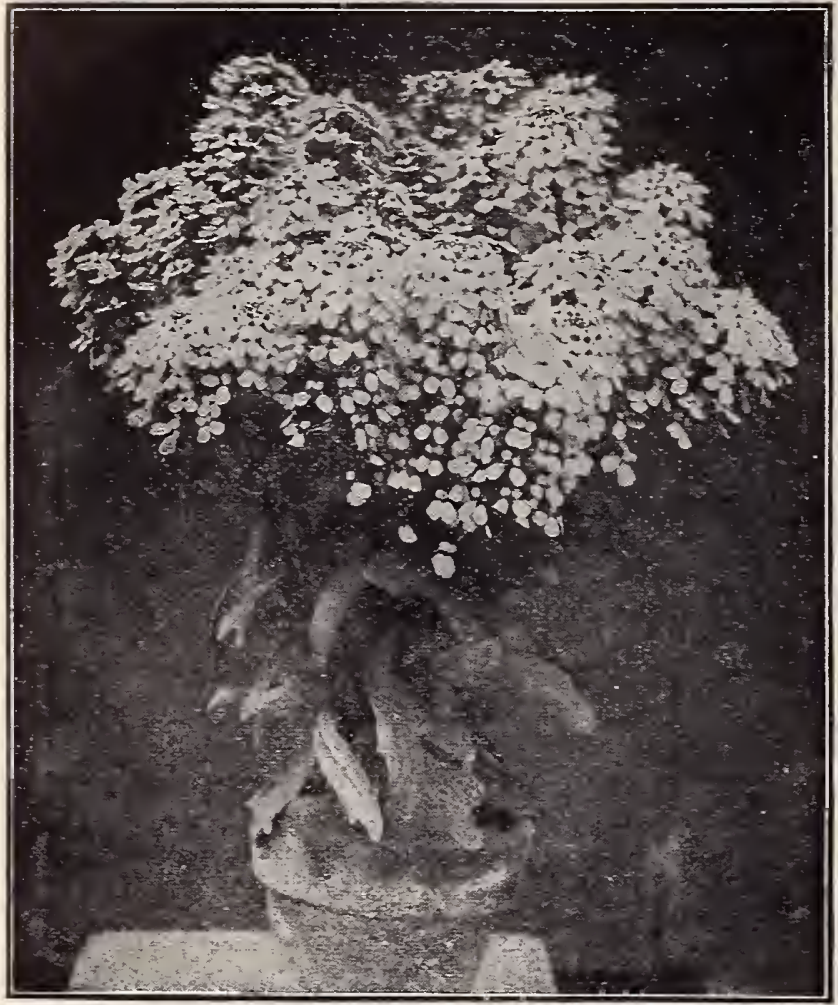

\section{CAMPANULA, Bell Flower}

The well-known popular, large, bell-shaped flower, known everywhere as Canterbury Bell, is a biennial Campanula. There are double varieties of every color, but, though curious, they are not really as beautiful as the old single bell; they lose that light transparent grace that is so attractive in a flower.

Canterbury Bell. Flowers large. Plants two feet high.

Pkt.

Single or double mixed, each

Single Pink New. A soft delicate shade. This color, combined witl the charming form of the Canterbury Bell, makes one of the most beauricup and Saucer. Calycanthema. Beautiful form of Canterbury Bell with a large "saucer" at the base of the flower.

Carpatica. Hardy perennial, six inches high, blooming the whole season. White and blue, mixed

Pyramidalis. Chimney Bell fower. Hardy, pyramidal plants three feet high, bearing hundreds of beautiful cup-shaped flowers. Suitable Grandifora. Platycodon. Hardy perennial, producing large broad bellshaped, showy, deep blue flowers, during the whole season. Very desirable for planting in permanent borders or among shrubhery.

\section{CALENDULA, Pot Marigold}

The well-known Pot Marigold, valued for fiavoring soups and stews. Flowers are dried in fall and kept in paper bags for use. In mild climates this plant will bloom nearly all the year round, and make a fine show in the flowergarden. Seeds can be sown in early spring in "open ground. Hardy annual. About one foot in height.

Double Sulphur. Flowers large and double. Color ligbt lemon-yellow Meteor. Handsome, double, and beautifnlly striped, tbe petals having a creamy center edged with orange-yellow .

Orange Giant. The finest large-flowered orange. Very double.

Pure Gold. Flowers golden yellow, extra large and very double. Prince of Orange. Fine orange. Double.

Mixed Varieties

\section{COCKSCOMB, Celosia}

Celosias are interesting and hrilliant annuals, and when grown from Tick's Selected Seeds never fail to please the grower and attract attention. There CANDYTUFT, EMPRESS

\section{CANDYTUFT}

Candytufts have long been among the most highly prized of garden annuals. The best effect is produced by raising the plants in masses, the seeds being sown where the plants are to bloom. Sow in rows sis to eight inches apart, and thin ont the plants so that those remaining will have plenty of room. The
soil slould be rich. When blooming time comes keep the plants well watered. Purple, White Rocket, Carmine, Lavender, Flesh, Extra Dark Pkt. Crimson. Each color, ounce, 30 cents

Mixed colors of above six varieties. Ounce, 20 cents

Empress. A pure white variety, of large size, and the finest in cullivation. Strong, free grower, producing large trusses of flowers, on candelabra-formed branches; individual flowers of large size. After devoting several years to selecting and saving seed from only the most perfect flowers, we have succeeded in procuring an extra fine strain of this grand variety. Ounce, 50 cents.

Pinnata. Compact plants with fine feathery foliage and pure white flowers. Splendid for edging. Retains a neat appearance throughout CANDYTUFT, HARDY

Handsome, hardy perennial plants, well adapted for permanent borders or clumps. Valuable for early decorating.

Iberis sempervirens. White, one foot.

Gibraltarica. Large, showy flowers; lilac, shading to wilte. One to two feet in height,

\section{CANNA}

The Canna will bloom from seed the first year if the seed is sown early: Seeds sbould be soaked for twenty-four hours in warm water before sowing. Crozy's New Hybrids. Gorgeous bedding plants, dwarf in habit, early bloomers, and remarkable for beauty, size of flower and foliage. If seeds he sown before April in hotbed or greenhouse, the plants will bloom in July, and continue until frost. These plants may be potted in the fall and lept blooming through the winter, or the roots may be taken up in late fall and re-planted tbe following spring. Mixed varieties; ounce, 25 cents Madame Crozy. Brilliant vermilion-scarlet, bordered golden yellow. . Mixed Tall Varieties of the old types. Among tbese are many fine colors not represented in the newer sorts. Ounce, 25 cents .

Dark-leaved varieties mixed, Ounce. 25 cents.

\section{are t}




\section{CENTAUREA}

\section{Bachelor's Button}

Centaurea Cyanus, Corn Flower, Ragged Saslor, etc.

One of our best known hardy annuals. Blooms freely and easily grown. Eighteen inches to two feet. Pkt.

Double Blue. Finest of the Corn Flowers. Full duuble fluwers of deep blue. $1 / 4$ ounce. 50 cents

Emperor William. Fine dark blue. Ounce, 30 cents .........

Pure White. Ounce, 30 sents. . Mixed colors. Ounce, 25 cents.

Centaurea Americana Basket Flower. Grows three to five feet, bearing immense thistle-like blooms on long stems. Handsome in the garden or as a cut flower.

\section{Sweet Sultan}

\section{Centaurea Imperialis}

These mammotl varieties are great improvements on the old Sweet Sultans. Easily cultivated, and succeed everywhere. 'l'he flowers are two to four inches across, of graceful form, and of the sweetest fragrance. Being on long, stiff stems, they are artmirably adapted for cutting and keep for a long time. liloom continuou

Odorata. Light blue.

Chameleon. Sulphur-yellow, changing through creamy white, to pink

Margueritæ. Pure satin white 1 . Parge fragrant flowers produced

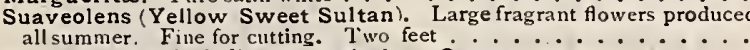

Mixed colors, including many shades. Ounce, 25 cents

\section{Dusty Millers}

\section{Silver-Leaved Centaureas}

Low growing white-leaved perennial varieties, used for.ornamental bedding. Sow early, inside.

Candidissima. Leaves silvery-white, much divided

Clementei. Densely white-woolly. Leaves broadly cut.

Gymnocarpa. Leaves silver-gray, finely divided

\section{CALIFORNIA POPPY}

The brilliant Eschscholtzia is California's chosen State Flower. The pla.ts grow to about a foot in height ; the leaves are of a grayish green color, finely cut and divided. The large, handsone flowers, two inches or more in dianleter, are produced in great profusion all summer. Seeds should be sown where the plant: are to bloom.

MIKADO. Brilliant orange scarlet. The deepest and richest color yet produced in the California Poppy.

Cross of Malta. Foliage silver-gray: flowers bright yellow, with a broad, dark orange cross in the shape of the Cross of Malta.

Mandarin. Inner side of petals a rich orange, the outside scarlet-urange.

Golden West. A beautiful variety: color light orange-yellow

Rose Cardinal. Outside of flower carmine, inside nearly white. :

Orange, Yellow and White, single, separate colors, each . . . .

Single-varieties mixed.

Double Orange and Double White, each.

Double varieties mixed

Eschscholtzia California

Poppy

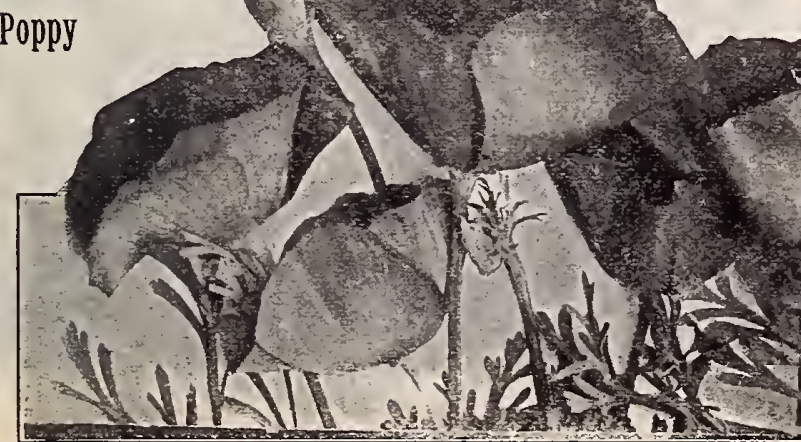

\section{0} 5 the stems often grow twenty or thirty fees long and inches long. In good soil Plants often grow twenty or thirty feet long and cover a iarge surface. edlye dorwin flowering when quite young. Put the seed in barely moist earth, appear, unless the soil is very dry. Purple.......... wo white ....... so

Dahlia Choicest double varieties mixed... Pkt.

Dahlia, Finest single varieties mixed...

\section{DATURA}

Large, strong-growing plants, with large, trumpet-shaped flowers. Roots can be preserved in the cellar like Dahlias. Three to six feet in height. Wrightii. The best single variety, white, tinged with lilac, sweet-scented. 5 Double varieties mixed.

\section{DOUBLE DAISY}

The well known English Daisy. Seed sown any time from June to August will produce flowers early the following spring. Transplants readily. Set about six inches apart. Perennial.

Best German Seed, mixed colors.

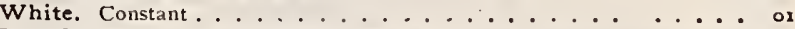

Longfellow. Large, rose-colored flowers ............ 10 Snowball. Large, perfectly double and pure white, having long stiff stems is

\section{COBOEA SCANDENS}

\section{COBOEA SCANDENS}

One of the most beautiful annual climbers, of rapid growth, with fine foliage: (1) 


\section{FOXGLOVE, Digitalis}

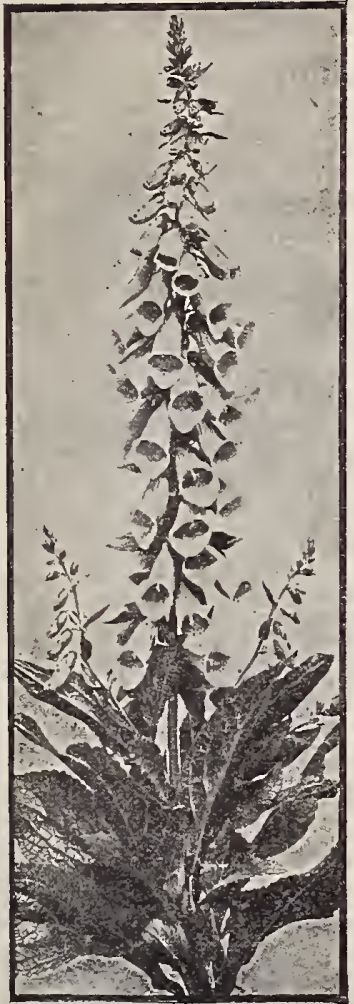

The Foxgloves are quite stately and highly ornamental plants when well grown, with flower stems at least three feet in he,ght. They are fine for the mixed border, or planted singly in half-shady places near a walk or drive. The racemes of flowers are often two feet in length, containing scores of the prettily-spotted thimble-shaped flowers. Perfectly liardy. Sow the seed in spring in tbe garden, and transplant as desired

Perennial.

\section{EUPHORBIA}

Mexican Fire Plant (Euphorbia heterophylla). "Fire on the Mlountaulı," etc. If grown in full sunligh leaves become brilliantly flared with scarlet, like a Poinsettia. Two to

Snow on the Mountain (Euphorbia marginata). Leaves beauti-

\section{HELIOTROPE}

This class of plants is one of the finest for cutting, as the delicious fragrance of all the varieties is very durable. Seed sown early in the spring in the house will make fine plants for summer bedding.

Queen Marguerite. Bears im mense clusters of large, dark blue flowers, with an exceptionally rich and spicy perfume.

Giant Flowered. Choicest mixed

\section{GOURDS}

The Gourds are prized for tbeir rapid growth and their odd-shaped and highly colored fruits. Tbey are useful for covering arbors, old fences, stumps, etc. The fruits, when allowed to rıpen, can be kept for years.

FOXGLOVE Balsam Apple and Balsam Pear have ornamental foliage. Wben ripe the golden yellow fruit opens, displaying the carmine interior. CALABASH. The old-fashioned dipper gourd.

IVild Cucumber. Echinocystis lobata. A fast-growing climber running 30 feet in a season. White fragrant flowers, prickly seed pods.

The following are some of the most valuable of the common varieties: Hercules' Club, Nest Egg Gourd, Serpent Gourd, Orange' Striped Apple, Sugar-Trough, or Sap-bucket.

Any of the above varieties, each, 5 cents; ounce, 30 cents.

Mixed varieties each, 5 cents; ounce, 30 cents.

\section{HUNNEMANNIA, Tulip Poppy}

Hunnemannia fumariæfolia, Giant Yellow Tulip Poppy. This most beautiful plant forms a shrubby bush two feet in height, with finely-cut foliage, similar to that of the Calıfornia Poppy and produces its large tulıp-shaped flowers on long stiff stems, from August till November

The color is a clear, brilliant yellow, the petals resembling crushed satin.

The flowers will keep in water for several days. Sow seed early in the spring, in shallow drills where tbe plants are to bloom.

\section{IPOMOEA, Moon Flower}

The Ipomoeas are climbers of rapid growtb. Succeed best if started in the hotbed and transplanted as soon as all danger of frost is past

Bona Nox(Good Night or Evening Glory, Moon Flower). Flowers

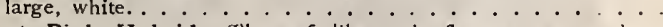

Giant Pink Hybrid. The soft lilac-pink flowers are produced abundantly all summer and fall. They remain open from about four o'clock in the afternoon until near noon of the next day: Seeds germinate quickly, and plants begin to bloom nearly as early as those of the Moruing Glory.

Grandiflora superba. Fine, large flowers, sky-blue, bordered with For other varieties of lpomica, see Cypress Vine and Morning Glory.

\section{GYPSOPHILA, Baby's Breath}

The delicate, mist-like sprays of the Gypsophila are invaluable for boquets. They serve to lighten the effect of masses of other flowers, and are especially useful with Sweet Peas, and other flowers that cannot readily be cut with their own foliage.

Paniculata. Baby's Breath. One of the best hardy perennials. Easily grown and blooms the first season from seed. Flowers white. Splendid for cutting

Muralis. Beautiful, hardy annual; six inches high, forming a dense mass. Fine for edgings. Blooms profusely. Flowers pink

\section{VICK'S HOLLYHOCKS}

In situations suitable for tall flowers we know of nothing better than the Hollyhock. New plants are obtumed from seed and by dividing the roots. Seeds sown in the summer will give plants that will endure winter. "Ihe plants may be protected during the winter with a little straw and evergreen boughs, or leaves. Biennial. See also Plant Department.

Hollyhock, Double. Four to five feet. Very double and fine, from the best named collection in Europe, ounce, $\$ 1.25$.

Alleghany. Six to seven feet. Flowers very large and beautifully fringed. Single, and semi-double. Has a long season of bloom, nd tbe plants are taller and less subject to rust than the double varieties. All colors mixed.

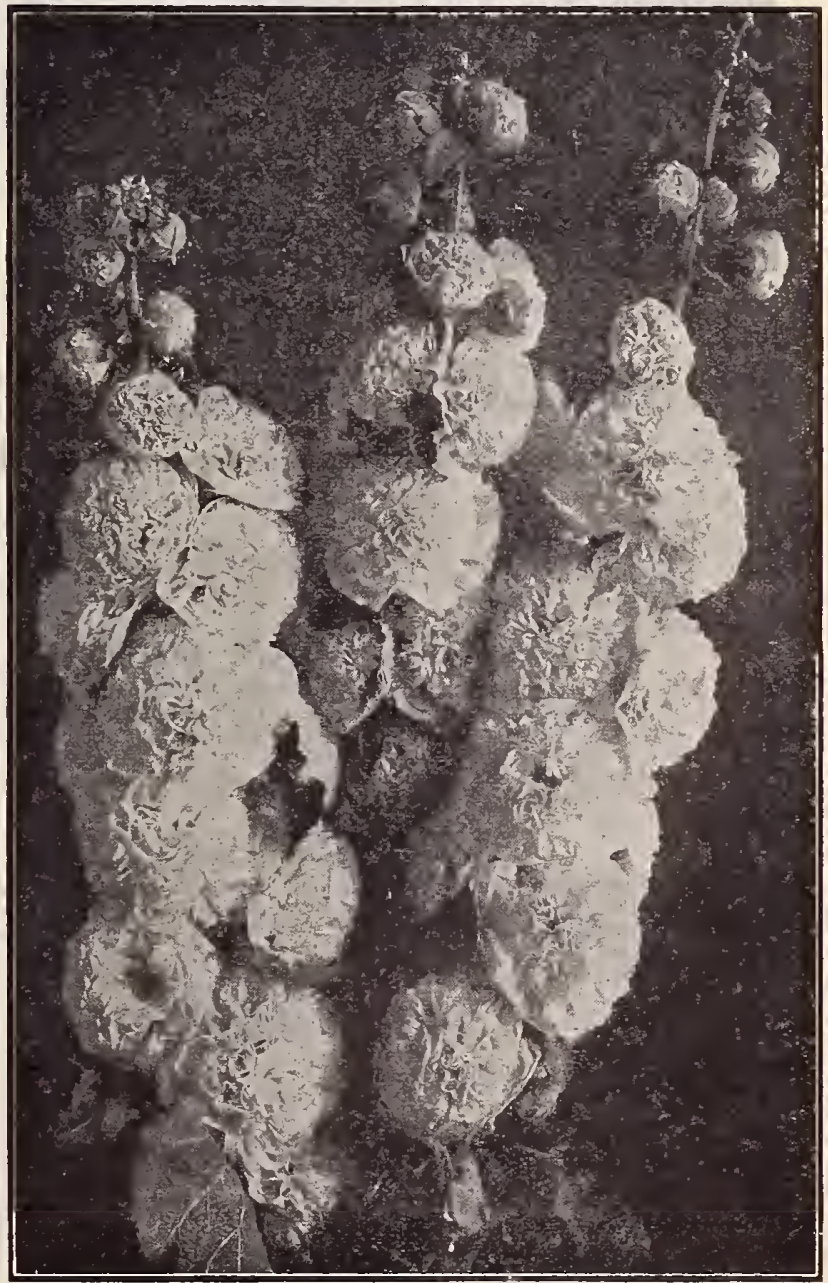

DOUBLE HOLLYHOCKS 


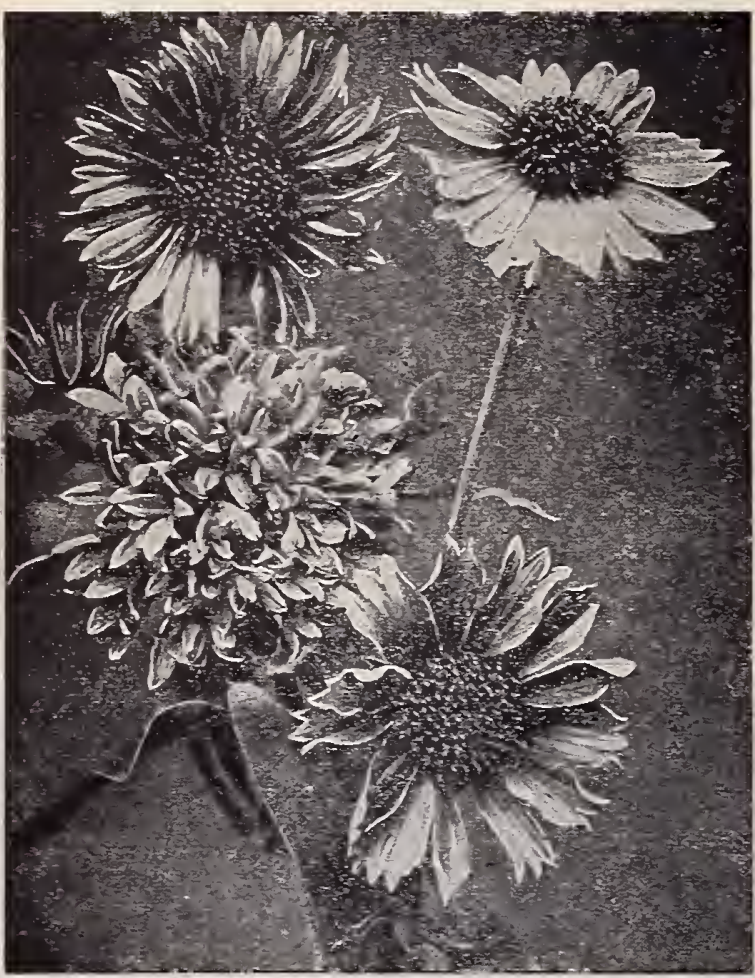

ANNUAL GAILLARDIA

\section{GAILLARDIA}

Gaillardias, known as Blanket Flowers, are good bedding plants, blooming continuously until late in the fall. Flowers large and sbowy, two to three inches across; fine for cutting, as tbey last a long time in water. Set plants twelve to eigbteen inches apart. Half-hardy.

\section{Annual Gaillardias}

Picta Lorenziana. Fine double. Flowers two incbes in diameter Pkt.

Aurora. Double. Red, tipped witb yellow, Fine large flower . . . . . ro Mixed single annual varieties

\section{Hardy Gaillardia}

Grandiflora. Perennial. The plants and flowers of tbe perennial Gaillardia are larger tban tbose of the annual. T be colors are exceedingly brilliant. Tbey include the richest shades of crimson, scarlet, orange and yellow, contrasting beautifully with the brown center.s. The plants are perfectly hardy and easily grown from seed. If seed is sown early the plants will bloom the first year. Mixed colors

\section{ICE PLANT}

Mesembryanthemum crystallinum. A pretty, half-bardy aonual, with delicate, succulent almost transparent brancbes and leaves. Of crooping habit, adapted to baskets, vase " ork, and rockeries. Prized for its singular foliage, which looks as though covered with particles of ice

\section{LOBELIA}

Exceedingly useful plants for edging flower beds, their free-blooming yualiies and brilliant shades of blue to white making a pleasing ccutrist to the masses of reds and yellows so prevalent in bedding. Tbey' are also elegant for banging baskets, pot culture, etc. All are annnals except Lobelia carcilialis, ubich is a bardy perennial.

Cardinalis, Our native Cardinal Flower. Spikes of brilliant scarlet. Blooms the first year if well started witb beat. The flowers are said to be tbe most brilliant scarlet tint that occurs in nature

Barnard's Perpetual. Flowers a brilliant blue, white ey $c$.

Crystal Palace compacta. Dark blue. For edging and carpet-bedding Emperor William. Ligbt blue; compact; very fine .

White Gem. Forms a ball of snow-wbite flowers

Erinus (gracilis). Blue. Fine for baskets or trailing purposes.

Mixed varieties, for baskets, etc.

\section{SUMMER CYPRESS, $\begin{gathered}\text { Kochia } \\ \text { tricophila }\end{gathered}$}

\section{Exceedingly Attractive as an Ornamental Hedge}

We consider tbe Summer Cypress wortby a place in every garden. It grows about three feet high, with many slender branches pressed close to tbe main stem, and resembles a small, closely-sheared evergreen, the slender foliage being a delicate light green. In September, tbe whole plant becomes a solid mass of crimson. Seeds germinate readily, and may be sown in the open ground about the first of May. The plants should stand about two feet apart. One-half ounce 20 cents.

\section{HYACINTH BEAN, Dolichos} Lablab. This really beautiful climbing plant is of quick growth; tbe foliage is handsome,
and tbe clustered spikes of flowers are borne in great profusion. The shining purple seedpods are also very ornamental. Tender annual, growing six to eight feet. Seed sbould be sown wbere plants are desired, in as warm and dry a spot as possible.

New Japan. A new and beautiful variety, witb large, pure white flowers, and waxy white seed-porls. Eight to ten feet.

\section{JAPANESE HOP}

A splendid annual climber, rapidly covering arbors, walls, trellises, etc. The foliage resembles tbat of tbe common Hop, but is much more dense. Seed soun in the open ground in spring will produce large plants in a short time. Withstands beat, drougbt, and insects. Japanese Hop

Variegated Japanese Hop. Leaves green aud white variegated.

\section{LINUM, Flax}

Scarlet Flax. Brilliant crimson flowers, an incb or more across, and a continuous bloomer. Annual.

Perennial varieties mixed.

\section{HARDY LYCHINIS}

Excellent bardy plants, of easy culture. To obtain good flowers the first summer, sow the seed inside and transplant as early as possitle.

Chalcedonica, (Maltese Cross, Jerusalem Cross.) Fine old-fasbioned flower Two feet bigh, with beads of brilliant scarlet flowers. Perennial.

Haageana hybrida. Finest of the Lychnis family. One foot in height. Mixed colors. Viscaria splendens. Flowers bright crimson. A very fine red-flowered hardy" perenuial

,

,




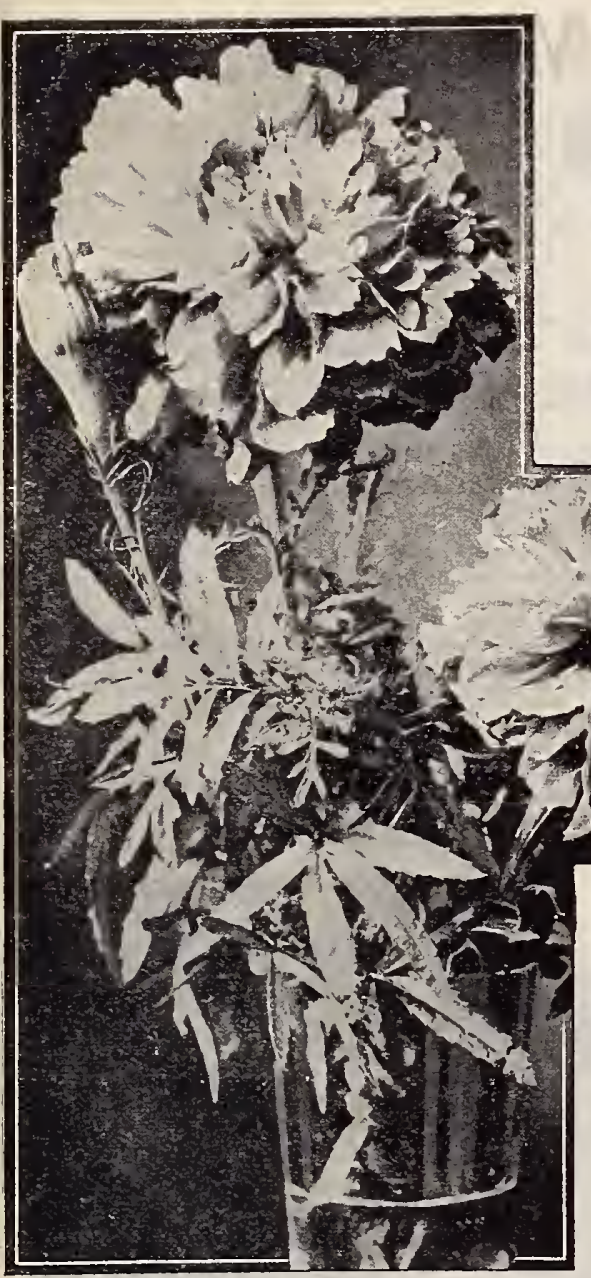

DOUBLE MARIGOLD

\section{FORGET-ME-NOT, Myosotis}

Charming, low-growing plants, the hright flowers covering the plants in late spring. Seed sown at any time up to mid-summer will produce plants that will bloum the following spring. Prefer moist sbady situation. The Alpestris varieties are very free bloomers; they are practically biennial.

Alpestris. Blue. Six inches.........

Alpestris Alba. White. Six inches.

Alpestris rosea. Liglit pink. Six inches. .

Alpestris Indigo blue. New, very fine. A deep indigo blue

Alpestris robusta grandiflora (Eliza Fonrobert). Large-flowering, of pyramidal habit. Very fine. Blue, with clearly defined yellow eye.

Alpestris Victoria. Sky blue, dwarf, strong-growing, globular, abunPalustris (True Forget-me-not). Blue, with yellow eye. A true perennial. Produces its charming blue flowers all summer.

rick's Perfection. The finest Myosotis known. Large, bright blue flowers. As an edging plant for beds or the shrubbery border it really has no superior. Plant robust, nine inches higb. .

Mixed varieties

\section{MAURANDYA}

Maurandyas are delicate and racefil free-blooming climbers, six to ten feet in height. Suitable for greenhouse or out-door culture, but especially usefill for baskets, vases, etc. The flowers are of good size; colors white, and various shades if rose,purple and blue. Seed should be sown in the hotbed, greenhouse, or in pots in a warm sunny window. Annual.

Finest Mixed.

\section{LARKSPUR, Delphinium}

\section{ANNUAL LARKSPUR}

Beautiful plants. The annual varieties are very free bloomers, and produce large spikes of flowers,

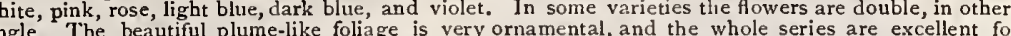

warf Rocket. One foot in height. Mixed colors, ounce, 25 cents

Colabrum. One foot in height; flowering late. Mixed colors

HARDY LARKSPUR

The Hardy Larkspurs are easily among tbe finest of all our perennial plants. The prevailing colors are rich, clear shades of blue. The taller kinds furnish long spikes of bloom that are strikingly decorative, and last a long time as cut flowers. The plants bave a long season of bloom, which can be greatly prolonged by keeping the seed stalks cut out and supply'ing Flenty of water. The dark, handsome foliage is neat and attractive throughout the whole season. The plants are perfectly hardy. Seeds sown in the open gronnc in the spring will produce strong plants, some of which will flower the same season.

Formosum. Large flowers of deep, brilliant blue, white eye. Three to four feet ... (Pil of

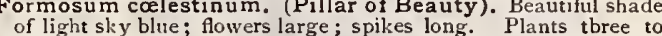
four feet in height. Nudicaule. Bright scarlet ; native of California. One to two feet Chinese. Fine. Two or three feet. Blue, white, and pink, mixed (home grown)

Large-flowering Hybrids. Three to six feet high. Flowers of various shades; very showy. Finest varieties mixed. Extra fine stock.

\section{MARIGOLD}

The African and French Marigolds are valuable for their flowers in late summer and autumn and grown to advantage in little clumps witb other plants in the front of sbrubbery or in the remaining in full bloom until killed by frost. Seeds can be sown in the open border, earlier in a coldfraune, and the young plants transplanted late in the spring to where they are remain. They succeed best in a light soil, with full expusure to the sun. Annual.

\section{AFRICAN MARIGOLDS}

Pride of the Garden. The immense flowers of this grand variety are densely double, and of a beautiful golden yellow color. A notable feature is the compact, dwarf habit of the plant, whicls forms dense bushes fifteen to eighteen inches high and two feet across

Eldorado. Flowers very large, ten to fourteen incbes in circumference, and extremely double quilled like a Dahlia; primrose, lemon, orange, and golden shades. Plants three feet in heigbt.,.. .

Lemon Queen. Large lemon-colored flowers

Mixed varieties. Ounce, 50 cents

\section{FRENCH MARIGOLDS}

Striped, yellow and brown ......................

Dwarf varieties mixed. Ounce, to cents.

Dwarf Marigold Little Brownie or Legion of Honor. A charming single flowered plant, about six inches hign. Very effective in masses or borders. Begins flowering extremely early, commencing in June. Color a brilliant gold. blotched with maroon

Gold Margin. Excellent. Flowers velvety maroon, margined with gold. Plant only eight inches bigb, bushy, compact, and free-flowering.

Tagetes signata pumila. A beautiful dwarf plant, forming a globular dense mass. Fine for bedding or borders

\section{FOUR O'CLOCK or MARVEL OF PERU}

The flowers of this old-fasbioned favorite open about four $0^{\circ}$ clock in the afternoon and fade the next morning. Two feet high, with bright foliage and fragrant flowers of desirahle colors. Set plants two feet apart. Makes a nice hedge if set a foot apart. Seed should be planted in the open ground where plants are desired. Tbe roots may be taken $\mu p$ in the autumn and preserved through tbe winter for spring planting, in the same manner as Dahlias. Marvel of Peru. Mixed colors. Ounce, 20 cents...

Variegated Foliage. Flowers of a variety of colors. 


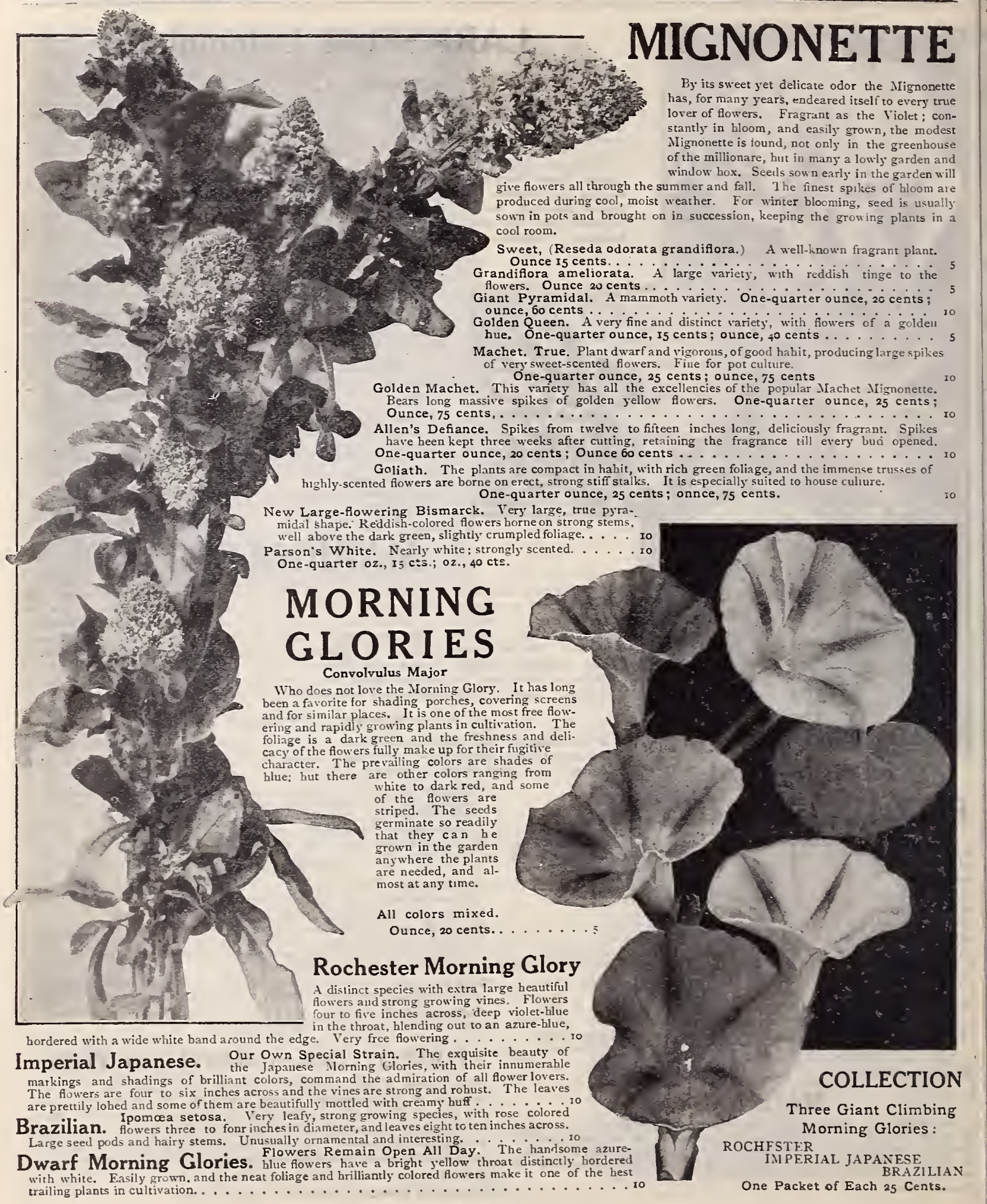




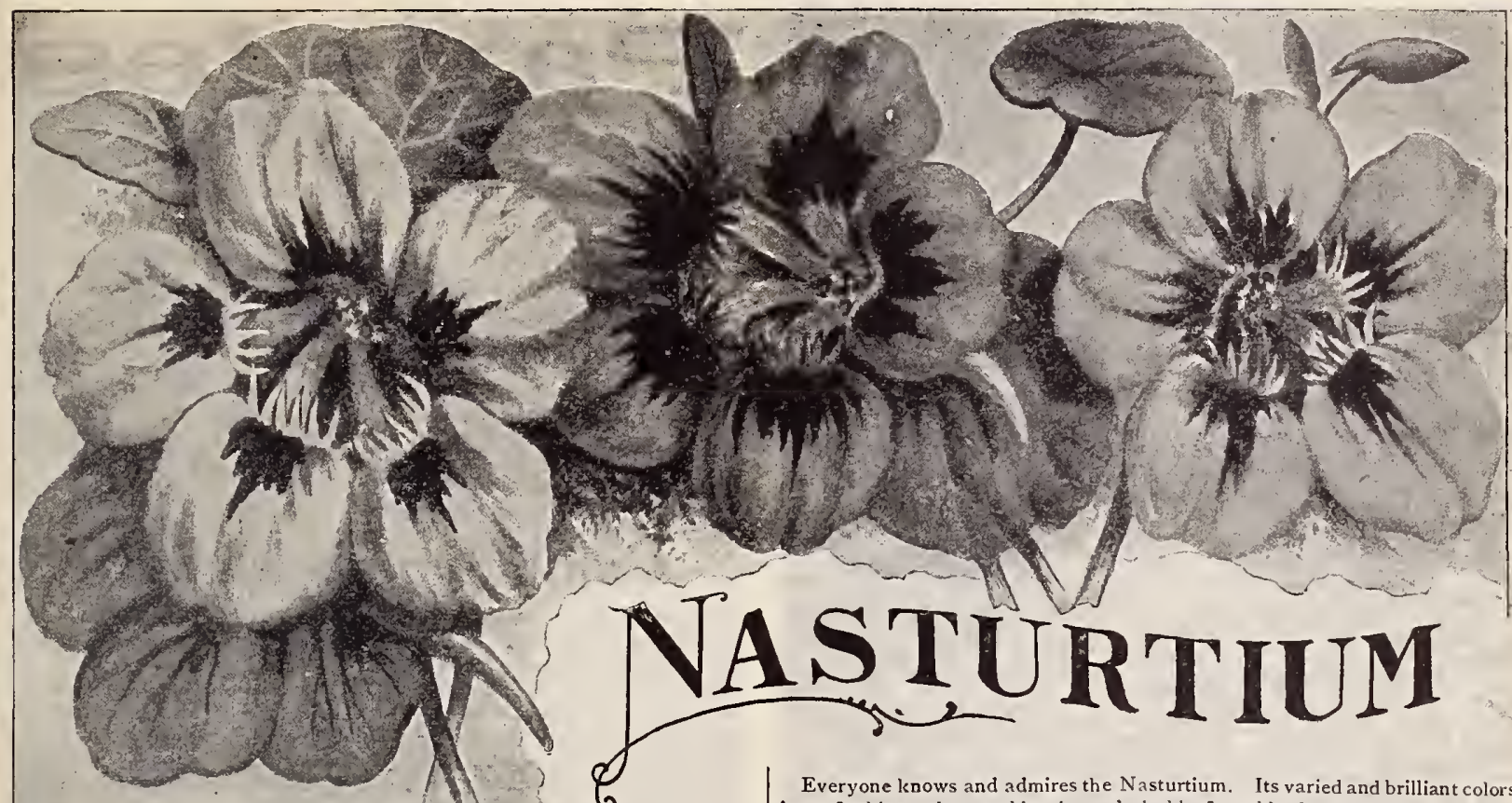

Everyone knows and admires the Nasturtium. Its varied and brilliant colors: refreshing odor, making it so desirable fur table decoration; its habit of continuous blooming, and the ease with which it is grown, unite to place the

\section{CLIMBING NASTURTIUMS}

Named varieties, $1 / 4$ lb., 40 cents; Oz., 15 cents; packet, 5 cents.

Atropurpureum. Dark crimson.

Atropurpureum fol. aureis. Foliage yellow, flowers crimson.

Chocolate.

Dark Orange.

Edward Otto. Bronze, silky.

King Theodore. The darkest.

Orange. Very handsome.

Pearl. Creamy white.

Prince Henry. Light yellow, marbled with scarlet.

Regelianum. Dark, purplish crimson

Scheuerianum. Straw-color, brown striped.

Scheuerianum coccineum. Scarlet striped.

Scarlet.

Schulzii. Brilliant scarlet.

Schillingi. Bright yellow

blotched with maroon.

Vesuvius. Brilliant salmon-rose dark-leaved.

Von Moltke. Bluish rose.

Yellow.

one Plaket each of the eighteen varieties above postpeid for io cents. Pkt.

Extid Cha Mixed. from named sorts, $1 / 4$ pound, 40 cents; ounce, is cents .........

Mixed vieties, Pound, 65 cents; $1 / 4$ pound, 20 cents; ounce,

ro cents

\section{DWARF NASTURTIUMS}

Named varieties, $1 / 4$ lb., 50 cents; ounce, 15 cents; packet, 5 cents. Eighteen of the varieties below, our selection, postpaid for 50 cents. Aurora. Salmon-rose, mottled and King Theodore. Flowers darkest veined.

Beauty. Orange and vermilion.

Bronze. Beautiful coppery bronze.

Carter's Scarlet.

Ch a m e le on. Nottled crimson,
bronze and yellow

cloth of Gold. Golden-leaved; flow-

ers intense scarlet.

Coruleo-roseum. Bluish rose.

Crystal Palace Gem. Sulphur, maroon sp ts.

Dark Crimson.

Empress of India. Dark leaves, and very dark crimson flowers.

Golden King. Golden yellow flowers. Very fine.

Golden Queen. A beautiful new golden-flowered, yell ow.leaved variety.

Extre Choice Hixed, from named sorts, $1 / 4$ pound, 50 cents; ounce, 15 cents.

vixed vorieties, pound, 75 cents; $1 / 4$ pound, 2 cents ; ounce. to cents.
King of Tom Thumbs. Leaves bluish green, flowers brilliant scarlet Lady Bird. Golden yellow, flamed crimson.

Pearl. Light crea.

Prince Henry. Light yellow, mar bled scarlet.

Regelianum. Dark crimson, purplish Rose. Rose, tinted with salmon.

Ruby king. Foliage dark, flowers

Scheuerianum coccineum. Scarlet striped.

Spotted. Yellow, crimson spots.

Spotted King. Rich orange, madeep rose. roon spots. Nasturtium in the list of flowers that are really indispensable.

\section{Variegated-Leaved Nasturtiums}

A new race of Nasturtiums in which the foliage is beautifully variegated with white, green and golden. The strikingly marked leaves make a charming contrast with the brilliantly colored flowerş.

Dwarf Variegated-Leaved. Scarlet flowers, ounce, 25 cents . . . . 10 Climbing Variegated-Leaved. Mixed colors, ounce, 20 cents...10

\section{Ivy-Leaved Nasturtiums}

The beautiful foliage of this distinct, new class of Climbing Nasturtiuns closely resembles that of the old English Ivy, the thick angular leaves having a very dark glossy green color. The petals of the flowers, which do not overlap as do those of the other classes, are prettily fringed. The brilliant colors of the flowers make a striking contrast with the dark leaves.

Ivy-Leaved Nasturtiums, ounce, 25 cents.

Princess Juliana. Rich golden orange; blotches of velvety red brown. io Emma Alida. Golden yellow and orange; blotches of deep scarlet. . . 1.0

\section{Hybrids of Madam Gunther}

A strain of French origin, most remarkable for the wide range of exquisite colors and beautiful markings. They are strong growers, climbing five to seven feet, with rich dark foliage. Fine for porches, vases or trailing on the ground. Ounce, :5 cents

\section{Canary Bird Flower}

Tropæolum peregrinum. The Canary Bird Flower is one of the finest of the climbing Nasturiums. The leaves are prettily lobed and the curious clear yellow flowers bear a fancied resemblance to a canary, with expanded

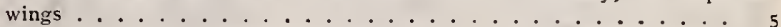

\section{NEMOPHILA}

Baby-Eyes, Love-in-the Grove. A charming little annual plant, thriving especially well in moist, shady places, but quite at home in the open garden. The pretty, bell shaped flowers, in shades of Whe, and variously marked, are freely produced all summer. Plants eight inches in height; of ueat, bushy habit. Mixed Varieties, ounce, 20 cents, 


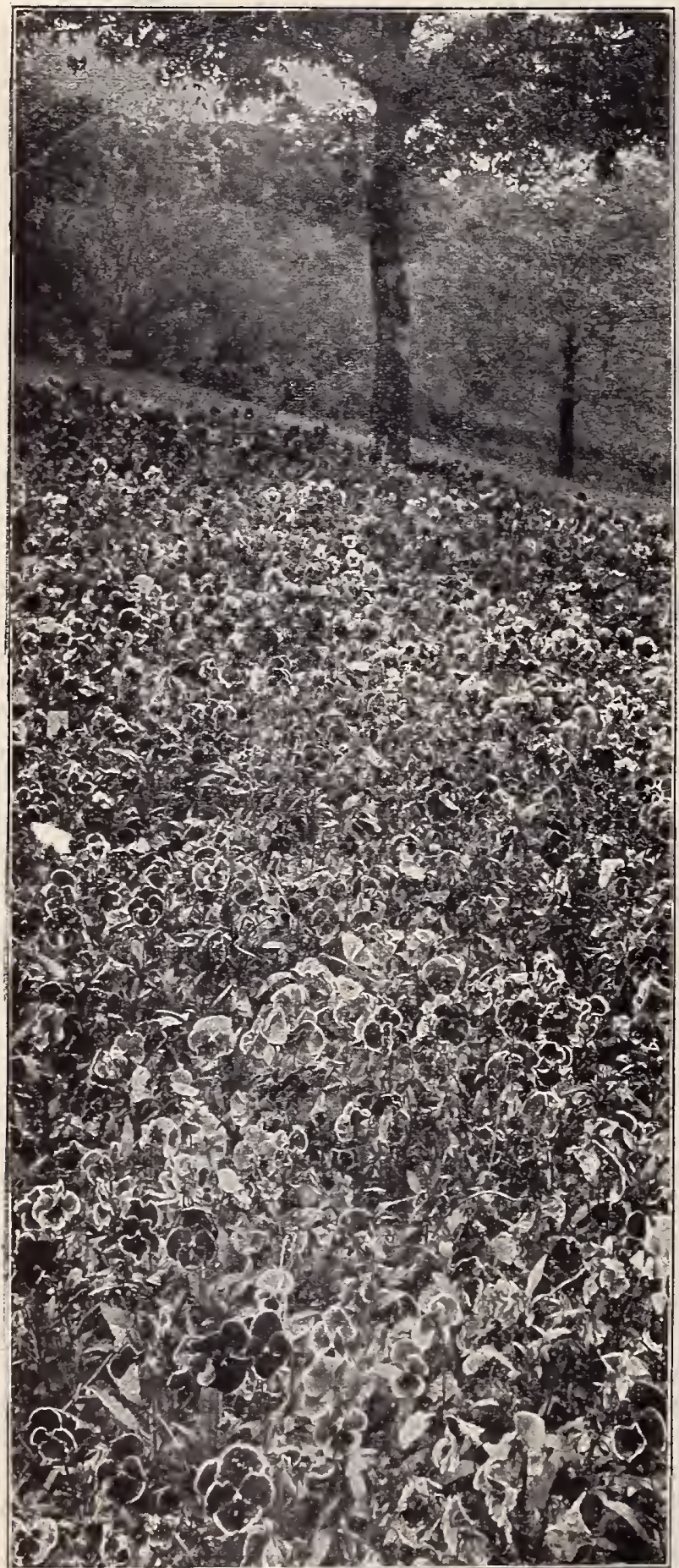

VICK'S BEAUTIFUL PANSIES

In Highland Park, Rochester; N. Y.

In spring and early summer, one of the most attractive places about Rochester is the great bed of twenty-five thousand pansy plants in Highland Park, a section of which is shown in the abore picture. This beautiful bed is a splendid testimonial to the high quality of Vick's Pansy Seed.

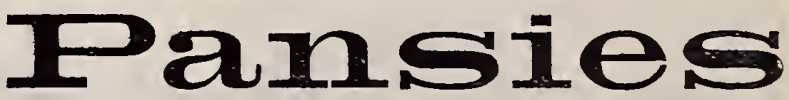

$\mathrm{T}$

HIE PANSY gives an abunclance of bloom tintil after severe frosts, endures our hard winters with safety, and greets us in the early spring witl a profusion of bright blossoms. Pansies are at their best during the cool, moist wenther of spring and fall. Seed sown in the open ground in May or June will give fine blooms in late summer and autumn, and a good crop of flowers the following season if the plants are pinched back in early spring. Seed sown in mid-summer, where it can be shaded and watered, will produce plants large enough to winter nicely and come into full bloom in early spring. Young plants give the largest flowers. Old, worn out plants should be replaced.

\section{Giant Superb Mixture}

No other grower of Pansy seed has yet succeeded in producing a mixture of such high grade as Vick's Giant Superb strain. Since we first introduced it, more than ten years ago, this superb mixture has not been equalled by any mixture offered to the public. 'The flowers are uniformly of the largest size, colors striking in their brilliancy and yet retaining all the delicate shades, hues and pencilings that have made the Pansy one of our most favored flowers. Each year we add to this Superb mixture many of the new and high-priced varieties, our aim being to keep it at the very; top of all mixtures, and to make it absolutely unapproachable in quality.

One-eighth ounce, $\hat{\$} \mathbf{1 . 2 5}$; packet, 50 cents.

\section{Peerless Mixture}

Comprises the choicest of the standard large-tlowering sorts, including many of the rare and expensive varieties, such as Bugnot, Odier, Cassier and Trimardeau types. For size, perfect form, freedom and durability of bloom, and gorgeous colorings, the Peerless Mixture will please the most critical grower of Pansies. For a charming display of show or exhibition Pansies you should try at least a packet of Vick's Peerless.

One-eighth ounce, go cents; packet, 25 cents.

\section{Masterpiece Mixture}

A new mixture of the choicest varieties of the Mnsterpiece or Giant Five-spotted class offered for the first time in 1912. From the many pleasing reports from customers who have tried it we are satisfied that it is one of the most satisfactory mixtures ever introduced. Masterpiece Mixture will give an unusually wide range of colors-white to deepest maroon or black, creany yellow to orninge, dainty rose to brilliant crimson - in fact, you will be delighted from day to day with the clianging colors in your bed of Pansies. We are offering Masterpiece Mixture at a very low price.

One-eighth ounce, $\$ 1.00$; packet, 30 cents.

GIANT SOLFATARA. A new color in the Giant FiveSpotted Pansies. The ground color is a delicate sulphur yellow or primrose color. Each petal is markerl with a very large deep blue spot. The effect of these contrasting colors is quite charming. The large flowers, about three inclies across, are perfect in form and are borne on long stems. Pkt. 25

GIANT VULCAN. The same class of pansy as Giant Solfatara. In the Giant Vulcan the ground color is a deep rich red. The large blotclies are nearly black. The color effect is extremely rich and striking ........... Pkt. 25 


\section{VICK'S PANSIES-Continued}

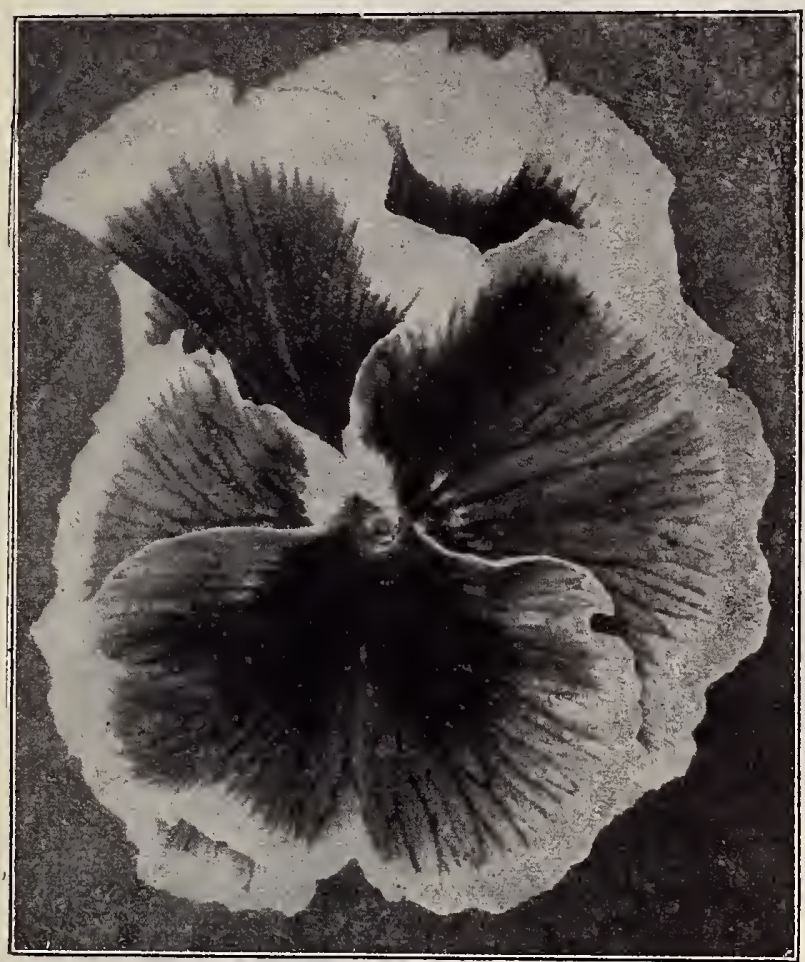

\section{Giant-Flowering Varieties}

A distinct class. Plants vigorous and compact. The flowers are thrown well above the foliage and many of them are marked with large blotches. They are of enormous dimensions, some specimens grown on our grounds measuring over three inches in diameter. We offer the following separate colors.

Pkt.

MASTERPIECE. Large ruffled flowers. Rich velvety colors, distinctly veined, and bordered with lighter colors. The long stemmed flowers have great substance and are splendid for cutting or for exhibition, . . . 20

Andromeda. This lovely frilled variety is of a delicate apple-blossom, showing a soft lavender or lilac hue, rendered more effective by a darker

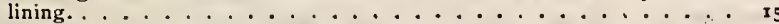

Adonis. Beautiful light blue .......... Bridesmaid, New. Rosy white ground, beautifully blotched. . . . . 15 Emperor Franz Joseph. White witb large violet blotches. A supe-

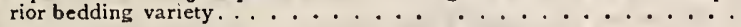

Fire King. Golden yellow, upper petals purple, Showy. . . . . . I5 Golden Queen. Large. Best of the pure yellows. . . . . . . . . ro King of the Blacks. Almost jet black. Extra fine large-flowering strain so Lord Beaconsfield. Top pale lavender; shading to purple violet on lower petals,. . True Petals frilled. Dark wine, pink, and red shades beautifully veined, all with white margin . . . . . . . . . ... Prince Henry. An extra fine variety. The largest dark purple. . . Prince Bismarck. Beautiful shades of golden bronze. The largest and finest of the bronze Pansies. ................. Psyche. White with violet blotches. Ruffled edges. A large and very

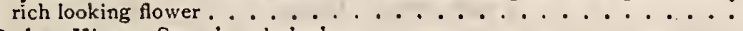
Ruby King. Superb red shades................. ro Snowflake. Extra fine pure white............. . . . . Yellow, with Black Eye Extra large, A splendid bedding variety. Produces larger flowers than the clear yellow varieties

Giant-Flowering Mixed. 1-8 oz., 60 cents ,

\section{Standard Varieties}

Each, 5 cents per packet.

Azure-Blue. Extra fine.

Cardinal, Brilliant dark red.

Dark Blue. Very rich, constant.

Dark Purple. Rich, deep purple. Fine.

Diana. Cream-colored; quite distinct.

Emperor Frederick. Dark red, bordered with orange-scarlet.

Emperor William. Ultramarine-blue, with violet-purple eye.

prince Bismarck. Beautiful shades of golden bronze.

Fairy Queen. Brilliant sky-blue, silver-white margin. Very showy.

Havana Brown. Beautiful shades of hrown.

King of the Blacks. Alniost coal-black.

Lord Beaconsfield. Top pale lavender, shading to purple violet on lower petals.

Mahogany-colored. Rich shades of brownish red.

Red Riding Hood. Brilliant red.

Snowy White. Good form and size.

Victoria. Rich velvety claret-red, large flowers.

Yellow Gem. Clear yellow, without eye. A gem.

Ten or more packets of the above seventeen Standard Varieties at four cents per packet.

Standard Varieties Mixed. $1-8$ oz. 25e.; pht. 5 cents

\section{PANSY VIOLET, Tufted Pansy}

The Pansy Violet, or Tufted Pansy, is a charming flower for the hardy border, combining the heauty, fragrance and free blooming habit of the Pansy with the hardy perennial character of tbe Viola cornuta, or "Horned Violet" of Europe. The plants do not "run out" like tbose of tbe ordinary Pansy, and may be left year after year in the same bed. The flowers, which are really medium sized Pansies, are produced in the greatest profusion the whole season, the plants enduring the heat of midsummer much better than those of the true Pansy . . . . . . Pkt. ro

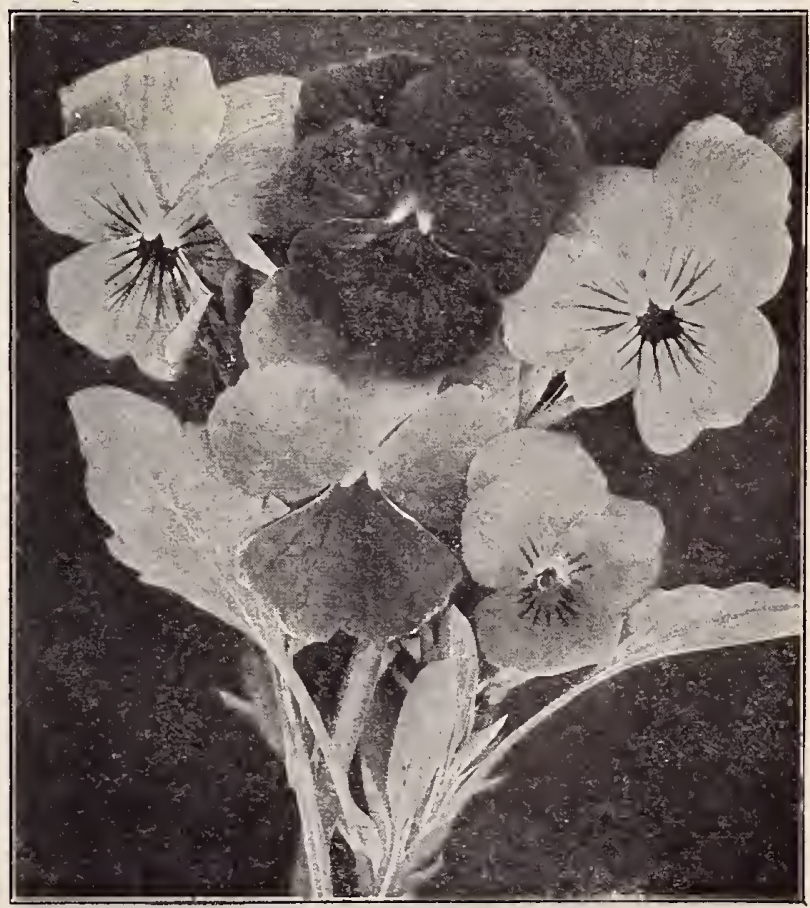


$\mathrm{D}^{\mathrm{ETUNIA}}$ seed will germinate

witb little difficulty if a reason-

able amount of care is used in

sowing. First, be sure tbat the soil is well pulverized; then sow the seeds on the surface, pressiug them into the soil by using a small smootb board and cover very lightly with sand or fine soil. Seed sown in a botbed or cold frame early in the spring, will produce flowering plants in June, Set the plants about eighteen inches apart. Seeds of Double Petunias do not possess as much vitality as those of tbe Single, neitber will all come double. Annual.

\section{Vick's}

\section{Ruffled}

\section{Petunias}

The most showy Petunias ever offered

No bedding plants make a more pleasing display than Vick's Ruffled Petunias. The distinct colors and markings make a brilliant sbow. Tbe plants make a strong growth and bloom profusely. One greenhouse $100 \times 20$ feet is devoted exilusively to tbis strain ; in it the plants are grown separately in pots and hand pollinated. This mixture is decidedly in advance of any otber foreign or American strain, embracing the greatest range of color, and the

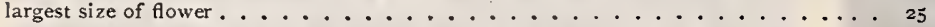

Large Flowering Single (Superbissima). Magnificent large flowers of various colors. The large throats ricbly veined. Mixed, from show flowers.

Vick's Single Fringed. Extra large flowers with frilled edges. Distinct and beautiful. Comes true from seed. Mixed colors.

Double Large Flowered, Fringed, Extra choice varieties mixed

Double Dwarf Bedding Petunias. The dwarf compact plants are profuse bloomers. Fine for bedding. Mixed colors

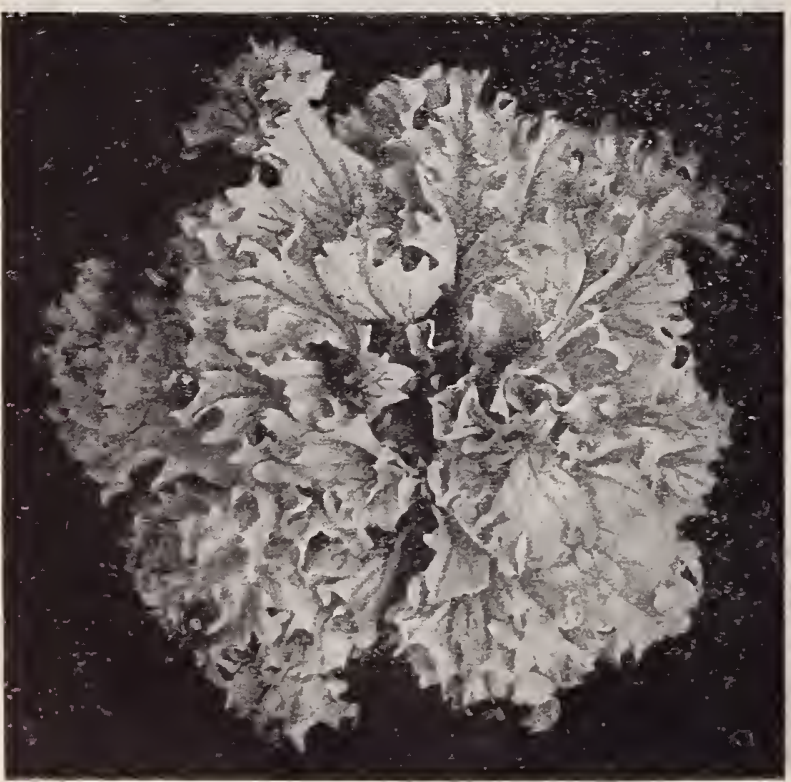

DOUBLE. FRINGED PETUNIA

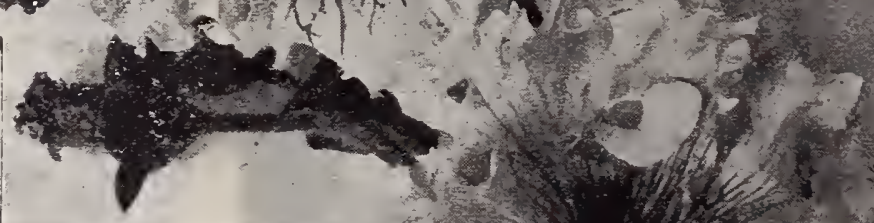

Vick's Ruffled Petunias

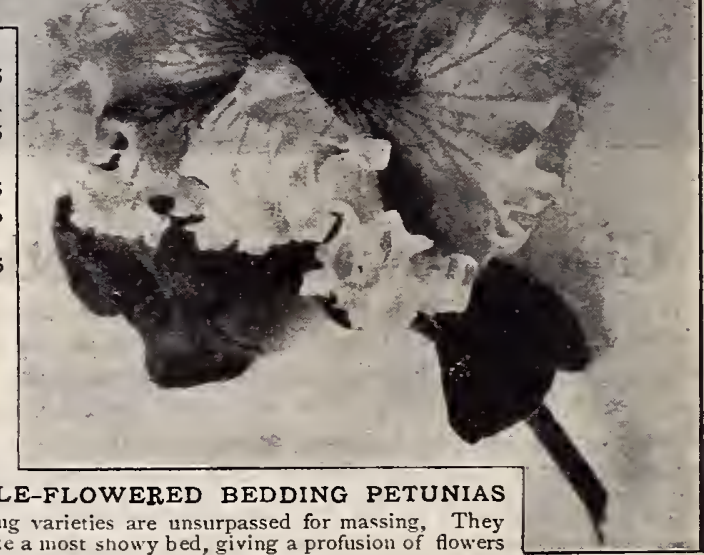

Bedding varieties are unsurpassed for massing, They will make a most showy bed, giving a profusion of flowers from early summer until after severe frosts.

Blotched and Striped, very symmetrically marked

Countess of Ellesmere. Dark rose, with fine white throat

General Dodds. Beautiful dark red Single Flowered Bedding. Extra Choice Mixed, Superb sirain. Io Single Flowered Bedding. Fine mixed.

"Giants of Califommia." This strain, originating in California, is of incomparable size, luxuriance, and beauty. Nearly all the flowers are ruffled or fringed, and measure from four to five inches across. The great variety of colors, blotchings, stripings and veinings make fantastic and beautiful combinations, -some with deep throats of yellow, white, black, green, or maroon, running off into intricate veins. Some of the colors run to delicate shades, while others are deep, rich, and gorgeous

\section{CENT COLLECTION}

Five Extra Choice Varieties from the above list, giving a wide range of types.

Large-Flowering Single (Superbissima). Mixed from show Bowers 25 Vick's Single-Fringed. Mlixed Colors. . - .

Single-Flowered Bedding Petunias, Extra choice mixed. $\therefore$ 25 Giants of California ................... 39

One packet, each, of the above for 85 cents 


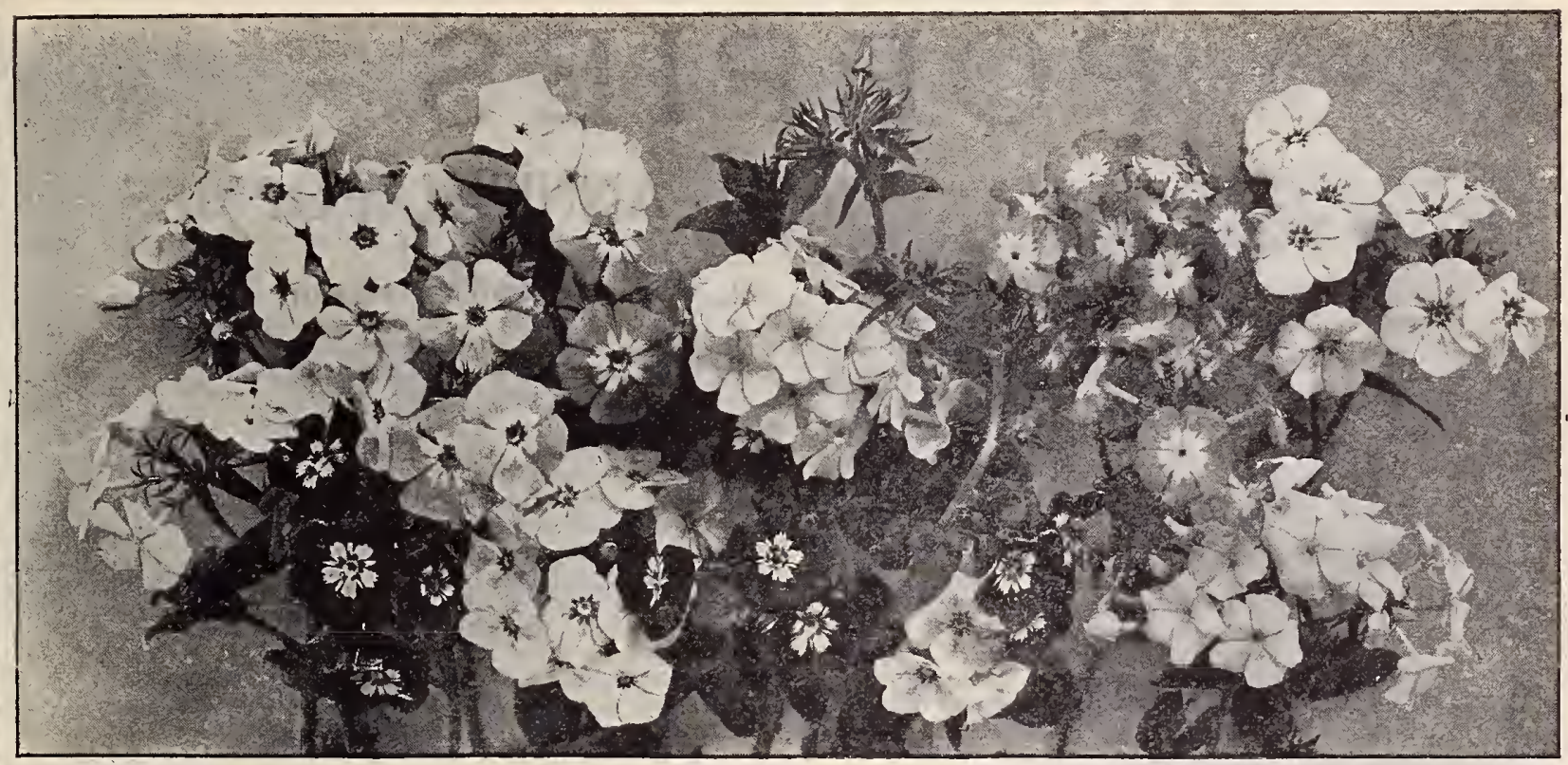

\section{PHLOX}

Phlox Drummondi is one of the most brilliant of all annual flowers. We grow several acres of anmual Plilox on our own farms every year and visitors are invariably charmed by the dazzling sheet of color presented by a field of Phlox in bloum. Phlox continues to bloom long after most flowering plants are gone, making it a splendid bedding plant. It is a native of Texas and thrives best in open sunny places. It does better if not crowded, the plants continuing to grow and bloom all summer. Easily grown and always in bloom, it is unexcelled for filling in vacant places in the gardeu, the shrubbery or the hardy borcier. It may be sowed as early in spring as the ground can be worked; or it may be started earlier in hotbeds or cold frames and later transplanted.

\section{Phlox Drummondi Grandiflora}

The flowers of this section have ronnd petals and larger flowers than the old sorts. These varieties we have found to come quite true from seed

White. Soft pure white.

Flesh Color. Delicate light pink.

Chamois Rose. Beautiful salmon pink.

Brilliant. Deep pink, shading lighter at the edge of the petals

Light Rose. A soft, pretty shade. Leopoldii. Rich rose color with white eye.

Carmine, White Center. A brilliant shade of rose.

Splendens. A soft shade of scarlet, between scarlet and carmine.

Splendens, White Center. The large white center gives a striking effect.

Quadricolor Rose. Each petal shaded from light to dark rose striking.

Light Yellow. Pale primrose yellow

Scarlet. A brilliant velvety color.

Dark Red. A deep velvety blood red, rich.

Dark Red, White Center, Rich and striking.

- Price, per packet, ro cents ; any seven for 55 cents.

The set of fourteen for $\$ \mathrm{r} .00$.

Grandiflora, choice mixed, One-quarter ounce, 25 cents; ounce,

75 cents.
Fine mixed

\section{Dwarf Phlox}

The dwarf annual Phloxes are very desirable for edgings and ribbon beds and useful for pot culture. They grow six to eight inches in height, forming dense masses of bloom all summer. Of the many varieties the following are the best. Fireball. Bright scarlet.... ro Best varieties mixed . Snowball. Pure white. .... Io
Best varieties mixed..... I0

\section{Star Phlox}

A decidedly unique variety. While the petals of all other Phloxes are entire, in this variety they are partly fringed and partly toothed: the central teeth of the petals are five or six times as long as the lateral ones, projecting like little spines, giving the flowers a regular star-like form. The beauty of the flower is enhanced by a white margin which borders the edges of the petals. There are many distinct colors. Best varieties mixed

\section{PERILLA}

Nankinensis. An elegant dark leaved bedding plant, easily grown from seed and not so sensitive to cold as the Colens. The foliage is a very dark, rich,

bronyy purple, Plants grow about eighteen inches in height. . . . .

\section{HARDY PRIMROSE}

In this country Primroses succeed best in a northern border. ${ }^{-}$Primula vulgaris is the sweet, beautiful English WVild Primrose, so ardently loved by all who spent their childhood days among the gieen lanes of England. Sow seeds where they can be kept shaded and watered, as they require a long time to germinate

Primula aurícula. Fine mixed..

Primula Elatior. Polyanthus. Fine mixed.

Primula Elatior. Polyanthus, Gold-laced. Choicest miced .

Primula Vulgaris. Wild English Primrose.

For ather varieties of Primula see sizge 75 and Plant Department.

\section{PYRETHRUM}

IIardy perennial plants of easy culture with beautiful, large, daisy-like, flowers in a variety ot brilliant colors. The flowers are borne on long stems and are splendid for cutting. The plants have a long season of bloom.

Roseum hybridum. Double varieties mixed.

Roseum hybridum. Single varieties mixed.

\section{SCHIZANTHUS}

The Schizanthus is a beautiful half-hardy annual, of very graceful habit. The flowers are butterfly-shaped, of rich and varied colors, and completely cover the plant. A bout two feet high. Best varieties mixed .

\section{SENSITIVE PLANT}

Mimosa pudica. The Sensitive Plant affords a good deal of amusement, on account of its sensitive leaves, which close up when touched. May. be sowed outside after settled warm weather, or sowed inside and transplanted. 


\section{POP P I E}

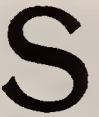

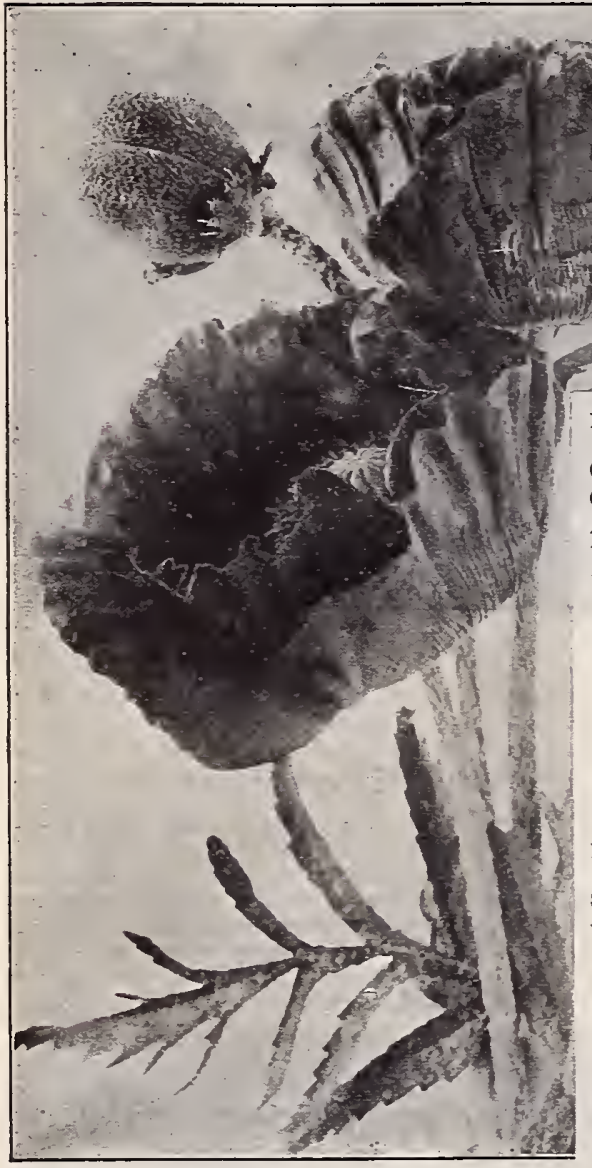

ORIENTAL POPPY

\section{ANNUAL POPPIES}

Ounce, 20 cents; one-quarter ounce, ro cents, except where noted.

Vick's Brilliant. Tall double Poppies. A superior selection made up of the best colors and varieties. Selected with great care to produce the most brilliant effect. Grown on our own farm. Of strong, robust growth, two to three feet higb.

Mikado. Large double flowers: resembling Japanese Chrysanthemums; petals cut and fringed in the most fantastic manner; color pure white, edged with shades of crimson.

Danish Flag. The large, single flowers are brilliant scarlet, with a large silvery white blotch at the hase of each petal, forming a white cross on scarlet ground. Very striking.

Peony-flowered. A splendid class of large double flowers, witb broad petals, resmbling a Peony The colors range from white to pink, carmine,"scarlet, crimson, and maroon.

Carnation-flowered, or Double Fringed. Splendid large double flowers. Mixed colors. . . .

Opium Poppy. True, single. Pound, go cents ; ounce, Io cents,

American Flag. Flowers snow white, bordered with scarlet. Large, double Peony flowered . . .

White Swan. Large double fowers, elegantly"fringed, pure white . . . . . . . . . . . Miss Sherwood. Very large single flowers of an exquisite shade of light pink. Grown on our own farm . . . . . . . . . . . . . . . . . . . . . . . . . Cardinal Poppy (New hybrids). About eighteen inches high : hahit erect and compact. Foliage dark green, deeply laciniated. The duuble flowers, which are beantifully fringed, cone in about

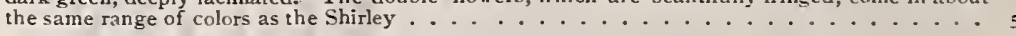

\section{THE SHIRLEY, or Corn Poppy Type}

SHIRLEY. Flowers excedingly graceful and elegant; single. Colors mainly blush white, and delicate shades of pink, but containing shades of rose, carmine, scarlet and crimson. The finest of all annual single Poppies. Extra selected strain. Grown on our own farm . . . . . ro Ranunculus-flowered. Plants two feet higb; free bloomers. Flowers double, $t w o$ inches across. All shades of color, from white to deep crimson. . . . . . . . . . . . . . Scarlet single. The single Scarlet Corn or Field Poppy of Europe. Very gorgeous... . . 5 Umbrosum. Of dwarf habit; branching. Flowers bright vermilion, witb a shining black spot on each petal. Very sbowy

The Tulip. An elegant and distinct variety. Plants from I2 to 14 inches high,producing well above the toliage fifty to sixty large splendid flowers of the most vivid scarlet imaginable. From a mere description no adequate idea can be gained of its strikingly beautiful effect. The plant commences blooming early in June, and flowers abundantly for a period of from six to eight weeks.

\section{PERENNIAL POPPIES}

Iceland Poppies are perennial, but blossom the first year from seed, if sown early. The plants are perfectly hardy, and bloom the entire season. 'The flowers are about the size and shape of those of tbe well-know'n Shirley Poppy (annual), and are borne on wirey stems a foot in length. The delicate silken texture of the flowers, nodding on slender stems, produces an exquisitely dainty effert. Charming as cut-flowers, lasting well if cut when the buds are opening,

Pure White, Yellow and Orange. Separate or mixed, each.

\section{Collection of the three Iceland Poppies, 25 cents}

Oriental. The single large Oriental Poppy is one of the most striking and showy of all the hardy garden plants. The tall stems, three feet in height, bear great flowers of brilliant scarlet six or eight inches across. The plants thrive well either in the full sun or in partial sbade. They are a great addition to the bardy border, and are of especial value among shrubbery, lighting up the usually dark and somber clumps of shrubs. The flowers are splendid for cutting, lasting well if cut as they are opening. The plants bloom in June. Perfectly hardy and easily grown from seed.

\section{"EXCELSIOR HYBRIDS," New}

A grand mixture of colors in hybrids of the Oriental Poppy, The result of several years' careful selection. Ranges from the most delicate salmon to deep crimson.

5

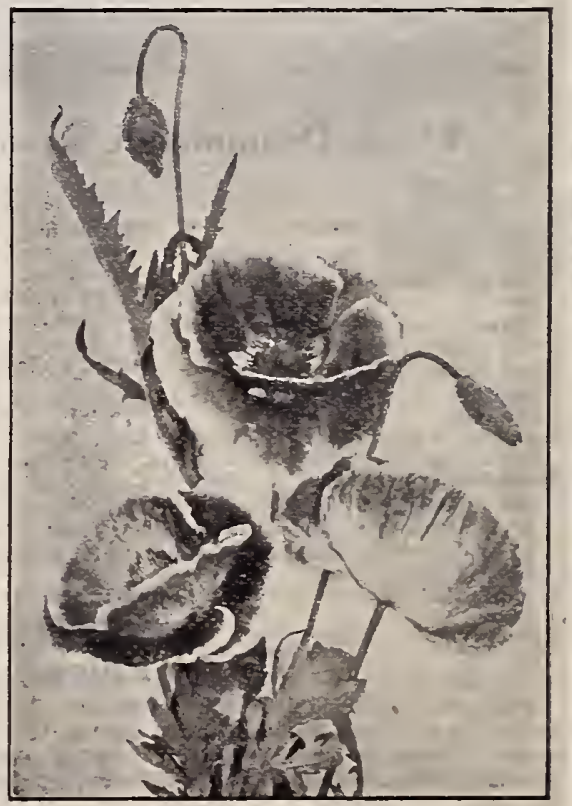

SHIRLEY PUPPY 


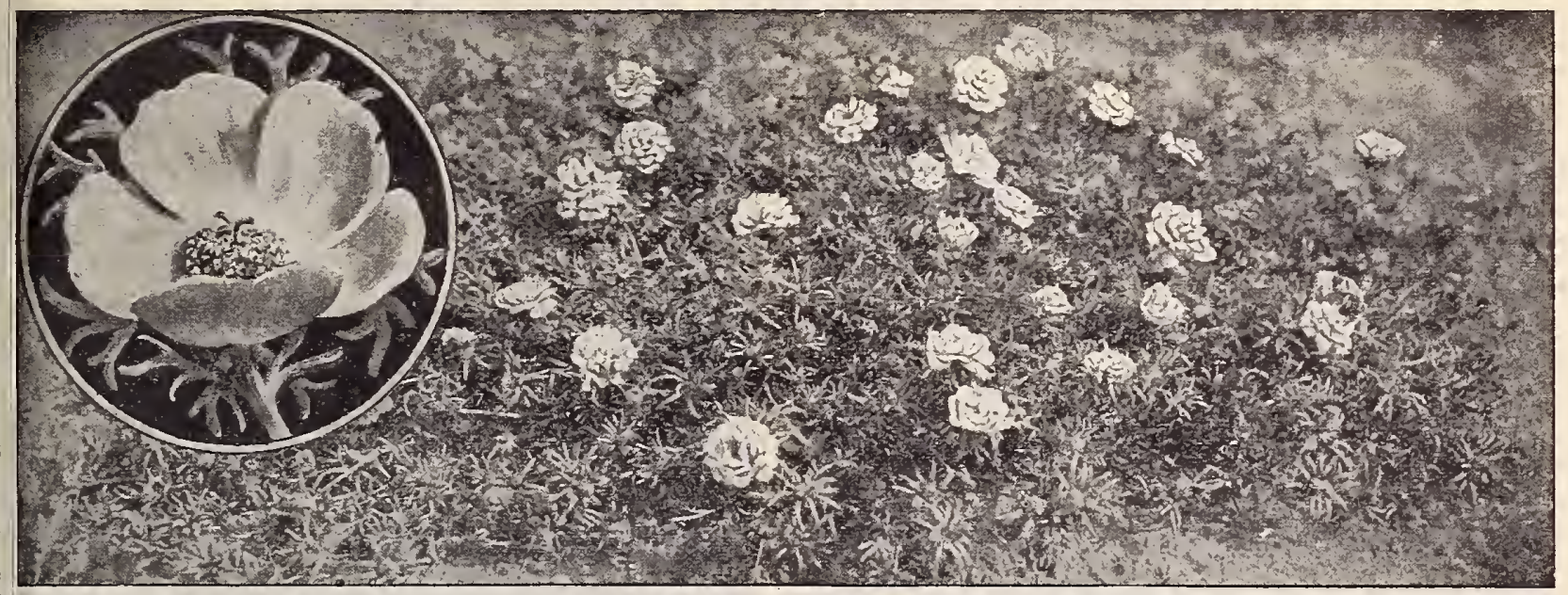

FLOWER OF SINGLE PORTULACA

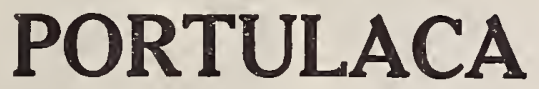

For brilliant coloring, nothing can exceed a bed of Portulaca, with its silky flowers glistening in the sınlight. It is very easily grown and no bedding plant equals the Portulaca for places exposed to the hot sun of mid-summer. It delights $\mathrm{n}$ intense heat, and dry, weather seems to have almost no effect on the plants. The plants are of low growth and spreading in habit, each plant covering a space of about $t$ wo feet in diameter. The flowers of the double varieties are ike small roses and make a particularly brilliant show. Sow seed in the open zround as soon as the weather is warm, or in a botbed earlier. The plants can be transplanted when in full flower,

Single varieties, fine mixed, ounce, so cents

Double Rose-Flowered. As double as the Rose and of many brilliant colors. First quality, mixed colors.

\section{RICINUS CASTOR OIL PLANT}

A Showy Ornamental Foliage Plant for Bedding In the center of a bed it gives a magnificent semi-tropicai appearance; or
danted thick, it makes a fine screen or hedge. Plant seed in open, very rich planted thick, it makes a fine screen or hedge. Plant seed in open, very rich Castor Oil Bean is cultivated for the oil, and grows about twenty bushels per acre. Annual.

Borboniensis. Very beautiful large green leaves. Fifteen feet, ounce, Cambodgensis. The finest dark-foliaged Ricinus. Leaves maroon; stem neirly black; fruit bronzy purple. Five feet, ounce, 20 cents.

Zanzibarensis The gigantic leaves, two to two and one-half feet across, and the great size of the plant, surpass any other known Ricinus. The luxuriant tropical appearance when planted singly or in masses is matchless. Ounce 15 cents

Mixed varieties of preceding. Ounce, 15 cents

Castor Oil Bean Ricinus communis, Pound 75 cents;

\section{SHASTA DAISY}

A very hardy perennial, blooming better and more abundantly each season, and continuing to bloom for several months. The pure white flowers are from two and one-half to four inches in diameter, and are borne singly on long, stiff, wiry stems. The blooms, when cut, remain perfectly fresh and in good condition for two weeks or more. Seed per packet, ro cents. Plants, each 20 cents.
PLANTS OF DOUBLE PORTULACA

\section{VELVET TRUMPET SALPIGLOSSIS}

Our illustration shows the form and veinings of this beautiful flower, but only nature cin paint its colors. Its velvety texture and brilliancy of coloring defy description. Nothing in our trial grounds is more admired than the Velvet Trumpet, its rich colors glowing in the sunlight. It is fine for cutting, lasting well in water. The plants bloom continuously fron midsummer until late fall. Sow the seed where the plants are to remain, cover with fine sand and press firmly into the soil. Two to three feet.

Grandiflora. Mixed colors .

5

New Emperor. This variety shows a very marked and striking distinction in habit of growth as well as in its flowers. It forms only one thick main stem about thirty inches high, which is thickly covered witb flow. ers considerably larger than those of the old type, and presents a compact bouquet, in the various rich velvety colors usual to the speciespurple, crimson, scarlet, rose, etc - veined with gold. Mix ed colors. .
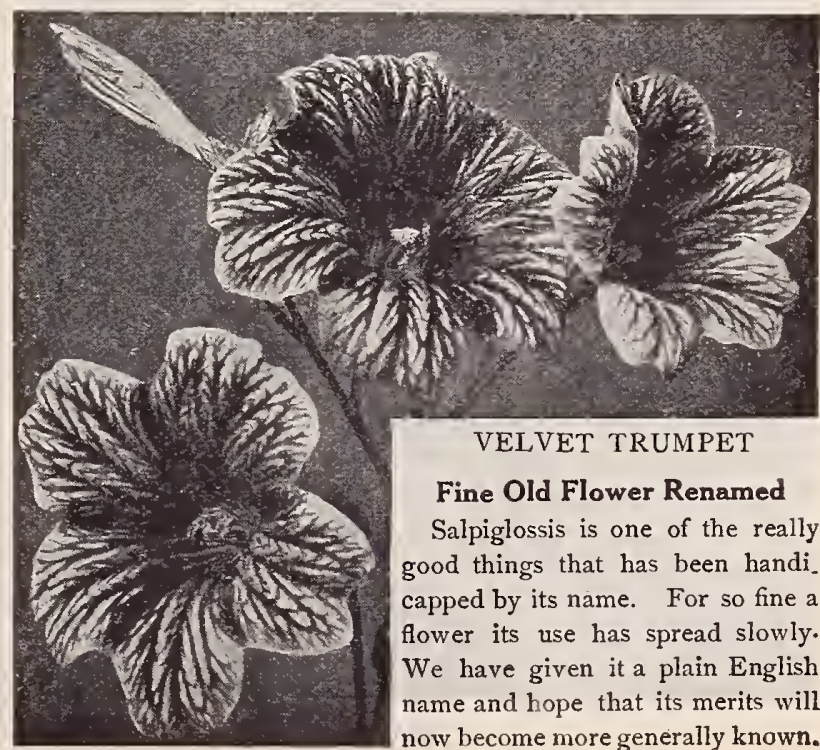

VELVET TRUMPET

Fine Old Flower Renamed

Salpiglossis is one of the really good things that has been handi. capped by its name. For so fine a flower its use has spread slowly. We have given it a plain English name and hope that its merits will now become more generally known. 


\section{SUNFLOWER, Helianthus}

Tall plants, from four to eight feet in height, with tright yellow fiowers. The double varieties produce a very good eftect among shrubbery. Utten used as screens. The seeds of the single varieties are valuable for feeding poultry. Chrysanthemum Flowered. Best of the Sunflowers, about seven feet. The large double flowers are like yellow Cbrysanthemums...

Dwarf Golden. Variegated foliage, five to six feet higb. Very effective as single specimens.

Extra Double Dwarf. About four feet higb. Eacb branch, from tbe ground to tbe top of main stem, bears a golden flower

Mammoth Russian. Tery large. Usually grown for feed. Per pound, jo cents; I/2 lb., I5 cents: $1 / 4$ lb., Io cents; oz..

\section{SALVIA, Flowering Sage}

The Scarlet Salvias are among the most brilliant red-flowering bedding plants in cultivation. They bloom from middle of July to frost. Sow seed ear'y indoors or in a frame in time to get good plants to set out of doors the latter part of May, or wben tbe weather is suitable. Massed in a bed, or a row or two around the veranda, they make a beautiful sbow. Succeed best in partial shade. Set plants one foot apart.

Clara Bedman. Bonfire. Tbe plants are compact and produce long spikes, of which there are sometimes two hundred to a plant, bearing from twenty to tbirty flowers each. For masses on tbe lawn or in the garden, or in row's along tbe walks, its brilliant, dazzling scarlet flowers are sim ply gorgeous

Zuricle. A new dwarf scarlet, growing from $\mathbf{r}_{2}$ to 15 inches higb and covered witb a mass of brilliant scarlet flowers borne on long erect spikes. Hegins blooming in June continuing through the season. . Splendens. True; larger and later tban Clara Bedman. Scarlet...... 10 Patens. Blue Sage, Flowers of a delightful blue.

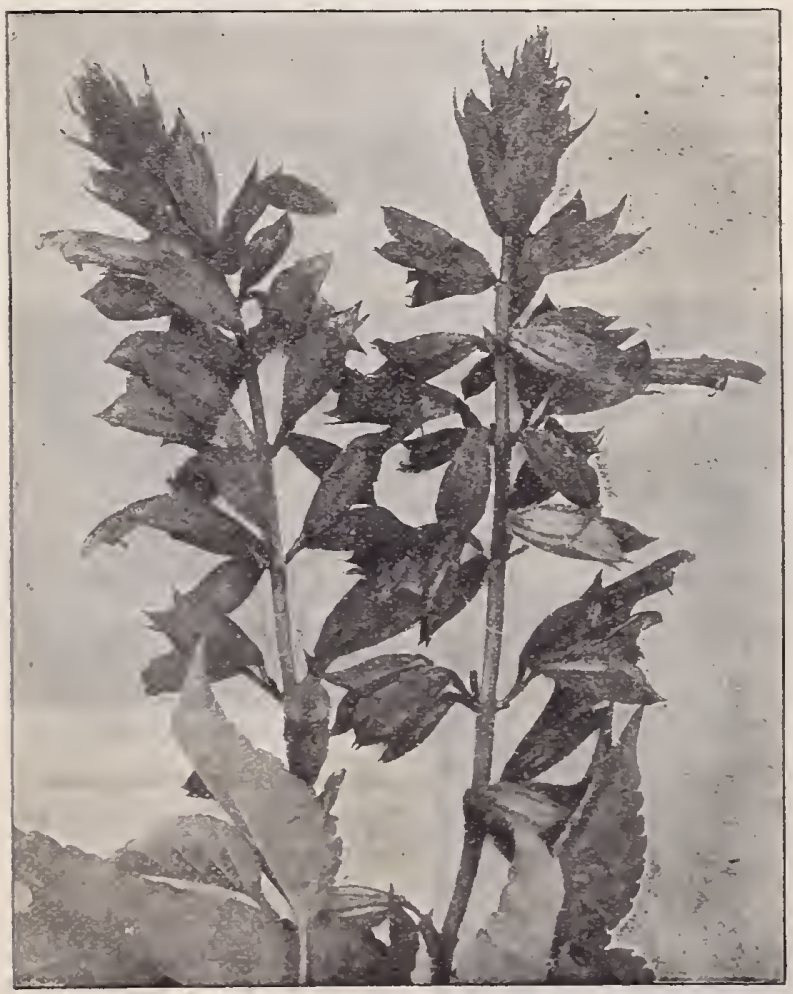

SALVIA

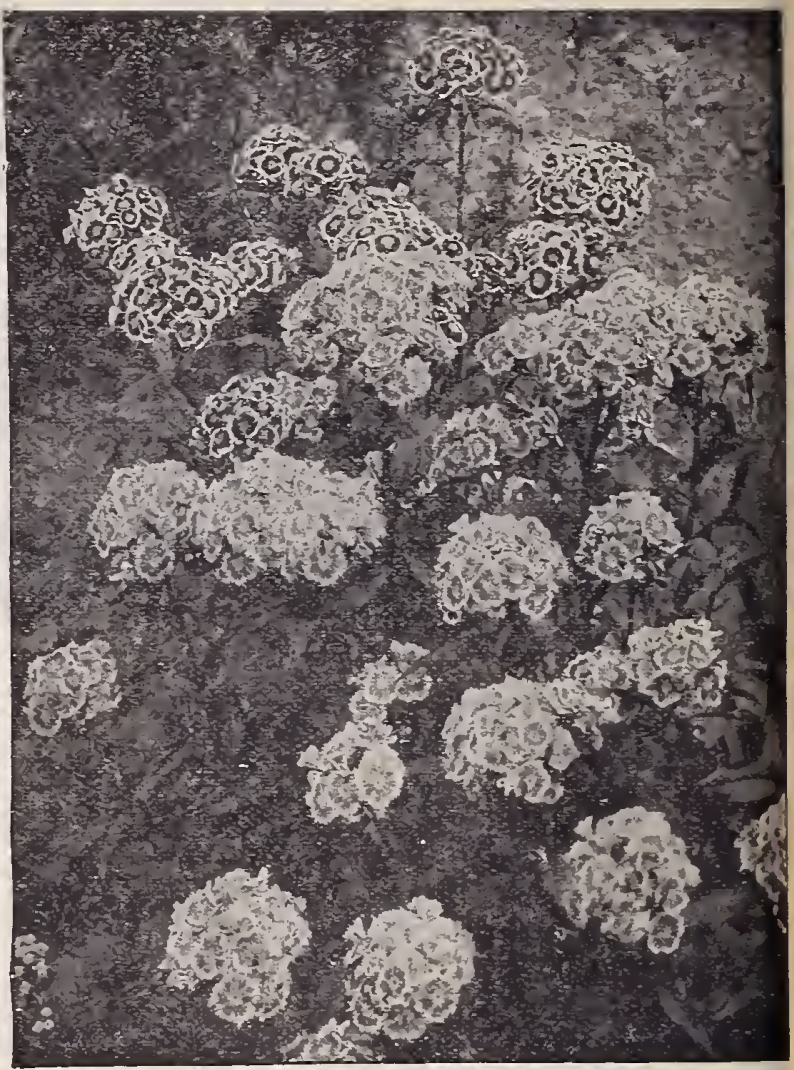

HOLBORN GLORY

\section{SWEET WILLIAM}

WV e are pleased to see that the merits of this sturdy old-fashioned flower art being more generally recognized and its cultivation greatly extended. Bealltiful, fragrant and easily grow $\mathrm{n}$, it is worthy of a place in every garden. The best varieties of Sweet William are of exceedingly beautiful colors, and the large fragrant flowers are borne in trusses of great size. They make a splendid show in the garden or hirdy border and last weil as cut flowers. Seed may be sown at any time from spring to mid-summer. Blooms the second season. Perfectly hardy.

Holborn Glory. Large flowers in beautiful shades, with center and marDunnetti. Deep blood red. Kich, velvety texture.

Pink Beauty. A beautiful salmon piuk

Single White.

Double White

Single Mixed. (Perfection.) All colors.

Double Mixed. All colors

\section{CORNFLOWER ASTER}

\section{Stokesia Cyanea}

This plant grows about 18 inches bigh, bearing freely, from early July until frost, its handsome lavender-blue Centaurea-like blossoms, each measuring from four to five incbes across. It is of tbe easiest culture, succeeding in any open sunny position, and is not only desirable as a single plant in tbe mixed bardy S border, but can be used with fine efiect in masses or beds of any size. We have no hesitation in saying that the Cornflower Aster is one of the most beautiful, valuable and desirable hardy plants.

Seed, per packet, ro cents, Plants, each, 20 cents, 


\section{SPENCER SWEET PEAS}

The magnificent new Spencer Sweet Peas are rapidly displacing the older kinds. The plants make a vigorous growth and the flowers are extraordinarily large, being, when well grown, from two to two and one-balf inches in diameter. In addition the petals are beautifully waved or fluted, and in some of the newer Spencers tbis fluting is very pronounced. Practically the whole range of grandiflora varieties has now been duplicated in the Spencer type; but after careful trials we have selected the following list as embracing the cream of the Spencer Sweet Peas.

\section{FOUR GRAND NEW SPENCERS}

King White has every requisite of a perfect Sweet Pea. The flower has inmense size, a bold expanded form, splendid substance and is exquisitely frilted. It has long stems, a large proportion of which carry four blossoms. When we add to this that the vine is a vigorous grower and a free bloomer, we think that you will agree that it would be difficult to imagine any improvement on King White .

Packet of 15 seeds, 15 cents. Packet of 30 seeds, 25 cents.

llluminator. A new and wonderfully striking color in Sweet Peas Illuminator is a combination of shades producing, under artificial light, a color effect of glowing orange scarlet. The ground color of salmon urange, shining through the rich cerise-pink with which it is overlaid, gives a delightfully rich effect. Our printed description conveys but a faint suggestion of the glowing leauty of this rare combination of unusual shades.

Packet of 15 seeds, 15 cents. Packet of 30 seeds, 25 cents.

Margaret Atlee. A rich share of saimon pink overlaid on a background of cream color. A charming shade that is unlike any other pink in Sweet Peas. The flowers are very large and most of them have double standards. A magniñcent new Spencer in the desirable creamy pink class. Small packet, 15 cents. Regular size packet, 25 cents.

Elfrida Pearson. Huge flowers of a dainty light pink, an extremely delicate shade. The buds and the opening flowers show a light salmon tint. One of the most vigorous and free blooming varieties. The iminense flowers are almost invariably borne four on a stem, and many of them have double standards.

Small packet, ${ }_{5}$ cents. Regular size packet, 25 cents.

\section{SELECTED SPENCER SWEET PEAS}

Packet, is cents; one-half ounce, 20 cents ; ounce, 35 cents. Any Seven Packets, your selection, for 50 cents.

America Spencer. Ivory white, striped with brilliant crimson-red. The brighest of the striped Swect Yeas. True Spencer form.

Asta Ohn. Light lavender tinted with mauve pink. A charming soft lavender. Large and beautifully waved.

Blanche Ferry Spencer. The old favorite Blanche Ferry in its "ennobled" form Bright rose standard and white wings.

Captain of the Blues Spencer. Large, clear purplish blue. A deep rich color. Full Spencer size.

Countess Spencer. Clear, scft, rich pink, a little deeper at the edges, Vines strong and free flowering. As a cut flower it is unsurpassed for massing.

Dainty Spencer. An extremely delicate shade of light pink, deepening slightly at the edges of the petals.

Etta Dyke. Pure white. Fine Spencer form, full size. Beautifully waved, Evelyn Hemus. The beautiful flowers of buff and primrose are margined with clear rose. A charming color combination.

George Herbert. Large flowers of rose-crimson. A rich color. The wings veined with deeper color.

Florence Morse Spencer. Splendid light pink, a clear, beautiful shade. Immense Howers, with inany double standards.

King Edward Spencer. A splendid variety. The flowers are full Spencer size and the bold coloring of rich crimson-scarlet makes them appear truly gigantic.

Margaret Madison. Clear, light azure blue. A refined color, free from mauve or pink shades. Both standard and wings beautifully ruffled. A gem that is bound to become immensely popular.

Mrs. Hugh Dickson. Soft apricot pink on a buff ground. The magnificent large flowers come quite uniformly four on a sten and are produced in the greatest profusion. An extremely valuable variety.

Mrs, Routzahn. Buff, tinted with blush pink and shading to apricot and rose at the edges. A charming combination of shades.

Queen Alexandra. Brilliant red. The nearest approacb in Sweet Peas to a true scarlet.

\section{Superior Mixture of Spencer Sweet Peas}

This mixture is made in our own seedhouse and contains the best of Spencer Sweet Peas. We know iust what goes into the mixtnre and we are sure you will be pleased with tbe assortment at blooming time.

Packet, Io cents; ounce, 25 cents; quarter pound, 75 cents ; half pound, $\$ 1.35$; pound, $\$ 2.50$

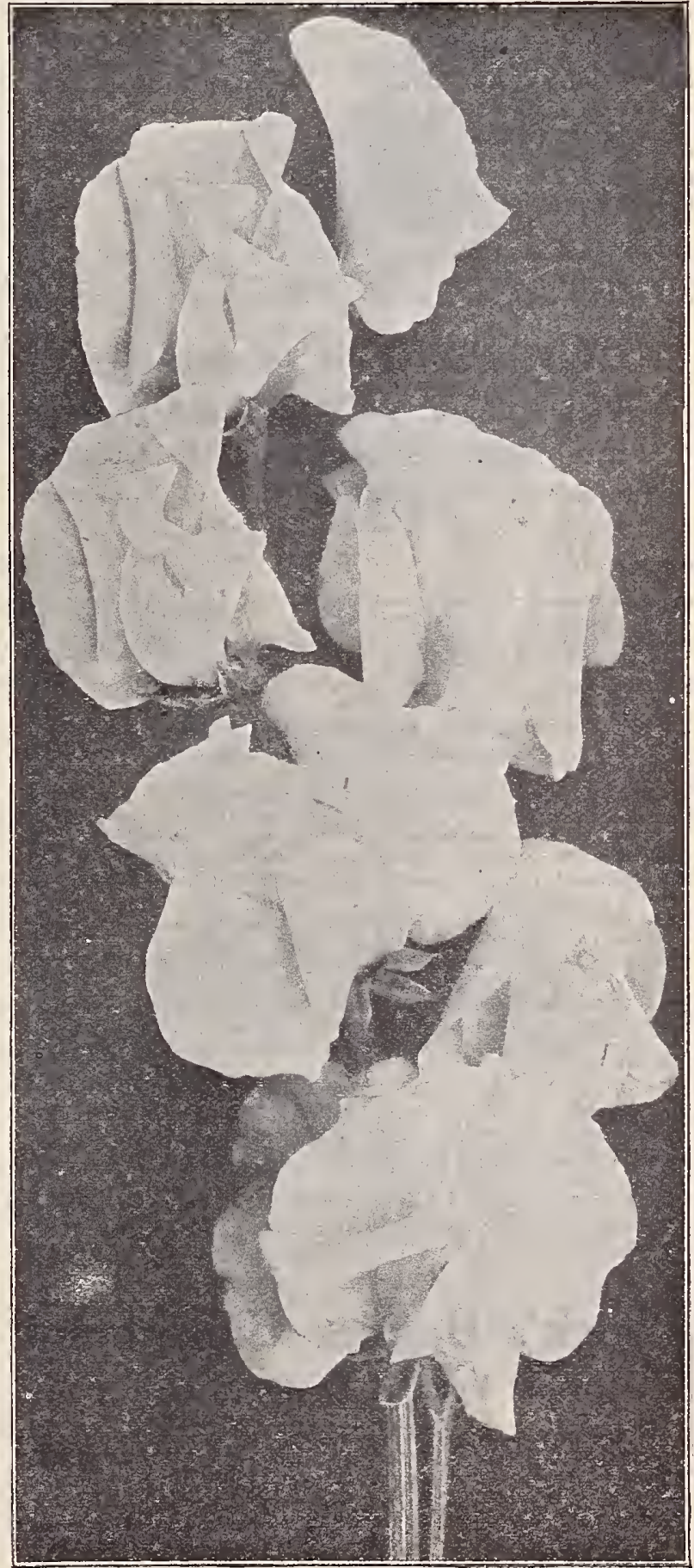

SPENCER SWEET PEAS 


\section{Sweet Peas}

$A$ NY ordinary garden soil is well adapted for growing these beauA tiful and popular climbing plants. Wood ashes or air-slacked lime are excellent fertilizers for Sweet Peas, and should always be used when a large amount of manure is applied. Sow as early in the spring as the ground can be worked. Do not wait for fair weather. Sow the seeds in a trench four inches deep and cover with about an inch of soil. After the plants are well up, thin them to about six inches apart and gradually fill the trench to the level of the garden. When hoeing draw the soil towards the plants, but do not form a ridge. One quarter pound of seed will sow fifty feet. Furnish support early. The one important point is to keep the surface of the soil fine and mellow from the time it is worked up in the spring.

\section{Grandiflora Varieties}

\section{Vick's Short Selected List Includes the Best Varieties in All Colors}

Per packet, 5 cents; ounce, 15 cents ; $1 / 4 \mathrm{lb}$., 40 cents ;

$$
\text { I/2 lb., } 80 \text { cents; lb., \$I.50. }
$$

America. Crimson scarlet stripes on white ground. The brightest striped variety. Large, open form.

Apple Blossom. Standard crimson pink. Wings wbite, sbaded pink. Hooded form. Usually four flowers to tbe stem.

Aurora. Orange rose stripes on white ground. The most attractive striped variety. Large, hooded form.

Bolton's Pink. Salmon pink, veined witb rose. Large handsome flower Semi-hooded form.

Dorothy Eckford. White. Very large, semi-hooded form. A grand flower.

E.J. Castle. Bright rose crimson, with veins of deeper rose. Large open form. Wary edges.

Flora Norton. The brightest and clearest blue. Medium size, open form.

Gladys Unwin. Bright, clear pink, a little deeper at the edges. Countess Spencer form, but a little smaller, lighter color and flowers more freely.

Hon. Mrs. E. Kenyon. Light primrose. Very large semi-hooded form.

King Edward VII. The largest and brightest red yet introduced. Crimson scarlet. Open form.

Lady Grisel Hamilton. The largest and lightest shade of lavender. Standard light unauve. Hooded form.

Lovely. Lizht pink, shading deeper toward the center of the flower. Vigorous and free bloomer. Hooded form.

Miss Willmott. Standard orange pink Wings rose, tinted with orance. The best orange pink. The large semi-hooded flcwers are borne on long stems.

Mrs. Geo. Higginson, Jr. The clearest delicate lavender, free from mauve tint.

Navy Blue. The best dark blue. Distinct and a vigorous grower.

Nora Unwin. White. A splendid flower. Extra large and open, wavy form Othello. Dark maroon self. Large, honded form.

Prima Donna. The favorite soft, clear, pink self. Good size. Hooded form Vigorous and free flowering.

Prince of Wales. The largest rose crimson. Vigorous and free flowering

Queen Alexandra. The nearest approach to a true scarler. Semi-hooded form.

\section{Vick's Banner Collection}

\section{Sweet Peas in Separate Colors}

The only way to become thoroughly familiar with Sweet Peas is to grow them separately and compare the different varieties when they are in bloom. To enable our customers to have, for a small outlay, flowers of all of the best of the standard varieties we have prepared VICK'S BANNER COLLECTION. This coutains 20 named varicties in separate packets, and covers the whole range of colors in Sweet Peas. It has been selected with great care snd includes many of the kinds in the above list of Grandiflora Varieties.

Banner Collection (20 packets) .......30 cents

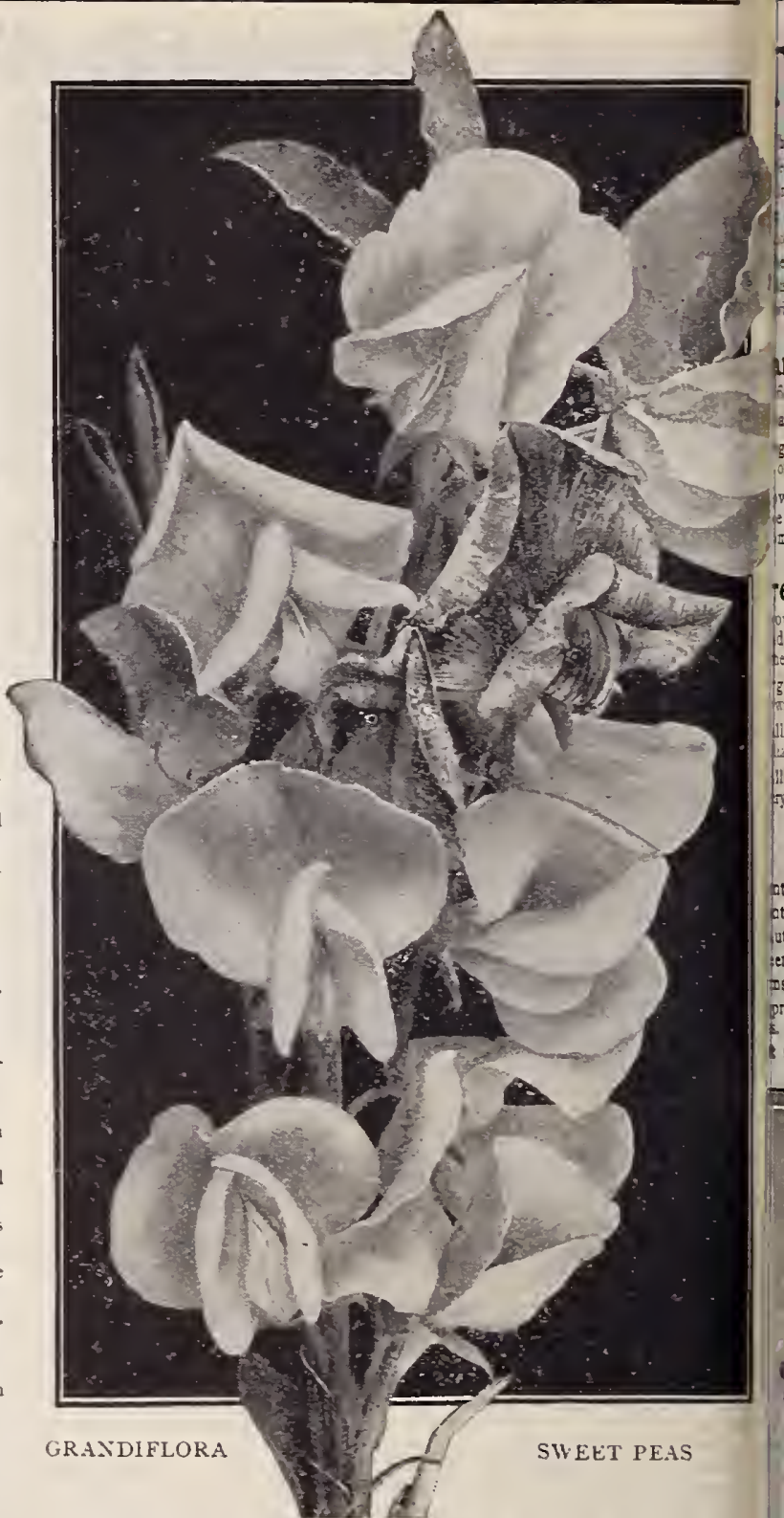

\section{SWEET PEAS IN MIXTURE}

rick's "Invincible Irixture", superior selected strains. The mixture introduced as "Vick's Invincible" we know will please the most exacting. For flowers of delicate colors, varying from pearly white to the richest reds and purples, the "Invincible" leads, because it is the result of selecting, year after year, seeds fron the choicest flowers. The sixture cannot fail to give satisfaction.

Packet, 5 cents; 0z. Io cents; $1 / 4$ lb., 30 cents; $1 / 2$ lb., 60 cents; pound, $\$ 1.00$

\section{PERENNIAL PEAS}

The Perennial or Everlasting Pea (Lathyrus latifolious) is one of the best of the hardy climbing plants. Although not fragramt like the Sweet Pea the large flowers are produced in clusters and the plants remain in bloor. for a long time. 'The Perennial Pea is very" easily grown from seed, will succeed in almost any situation and once established will remain for jears without replanting. It does well in shady and in moist places where other climbers would not thrive. Perfectly hardy. Grows from five to eigbt feet in beight. White, Rose and Red, each .

Mixed colors. 


\section{TEN WEEKS STOCK}

The Ten-Weeks or Annual Stock has nearly or quite all the requisites of a perfect flowering plant-good hahit, fine foliage, fragrance and beautiful llowcrs of almost every desirahle tint. The flowers last a long time and the side shoots give a succession of blossoins. Seeds may he sown in the open ground, hothed or cold-frame, hut transplanting should he done when the plants are just out of the seed-leaf. Make the soil deep and rich, and set the plants a foot apart. If plants from a late sowing are carefully potted in the fall, they will flower finely in winter in a house that is tolerahly cool and moist.

Largest Flowering Dwarf. From pot-grown plants. nificent large spikes of large double flowers. All colors mixed. ... . ro Dwarf German, from field-grown plants. Mixed colors. . . . . . . 5 Large-Flowering Pyramidal Dwarf. Of pyramidal habit; long spikes of large flowers. Chorce colors mixed . . . . . . . . . I

Snow Flake. Dwarf Wallfower-leaved. The earliest white, and one of the earliest of all len-weeks Stocks. The snow-white llowers are uncommonly large and double. An extra choice strain ....... 25

Dresden Perpetual Aut-and-Come-Again, or Princess growth and hranching habit. If sown early commences blooming in Jine and continues until frost, producing flowers in September and Uctober, when other varieties have faded. Fine for cutting.

Large-flowering Wallflower-leaved. Smooth, dark, shining leaves. Dwarf. Set six inches apart. Mixed colors ........... Wallflower-leaves: White. A heautiful clear white, with dark glossy foliage, Grown largely for cut flowers . . . . . . . . . . . Wallflower-leaved Blood-red. The deepest red of all the Stocks. A very choice viriety, prized by florists for cutting .

\section{Early Large-flowering Winter Stock}

Giant Nice, White. Very fine variety. . . . . . . . . . . . 10 Giant Nice, Yellow. Excellent. . . Beauty of Nice. Strong spikes, with large flowers of a delicate flesh pink to Queen Alexandra. New. Rosy lilac, similar to preceding. Splendid. 15 Crimson King. New. Brilliant fiery crimson. Beautif.ul.

Empress Elizabeth. Splendid. Immense spikes of hright carmine flow ers. Superh hoth for pots and cutting . . . . . . . . . .

Best mixed colors

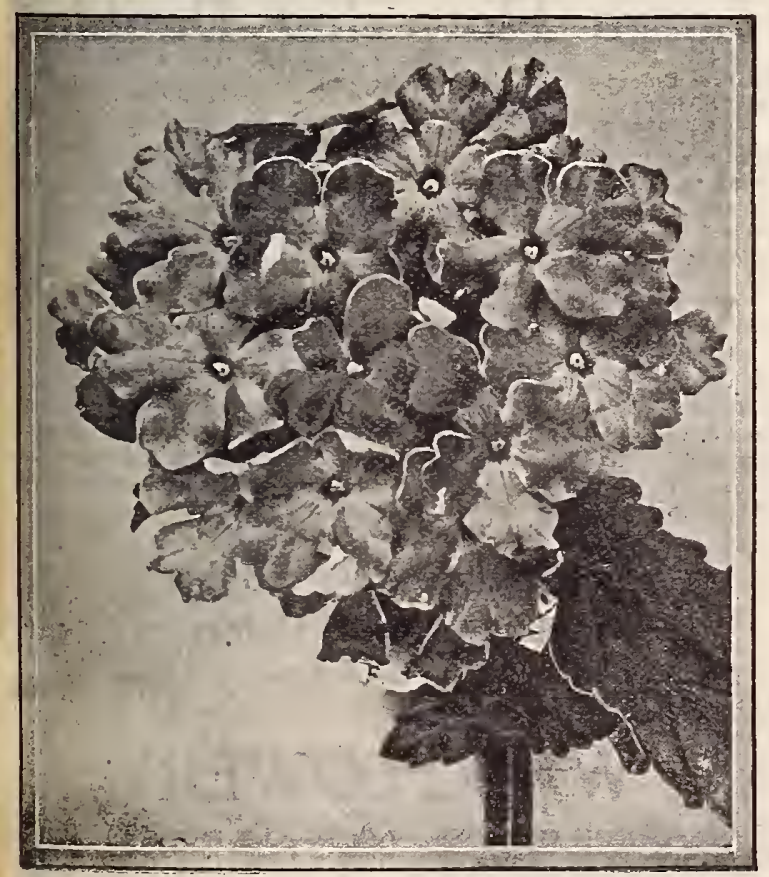

VICK'S VERBENAS

\section{SCABIOSA, MOURNing BRIDE}

The Scabiosa is an old favorite and of late y cars has heen greatly im. provcd. The flowcrs are horne on long, wiry stems in white, yellow, pink, scalet, crimson and ma. roon. Beautiful in the garden and excellent for bouquets. Very easily grown a $\mathrm{nd}$ has a long season of bloon. Twelve to eightcen inches high. Aunual.

Double Tall. Mixed colors .... 5

Double Dwarf. A pretty coin pac t plant. Mlixed colors 5 Double Yellow. A distinct culor, obtained after years of careful selection. . I

Double White. Sn o w ball. Pure white.

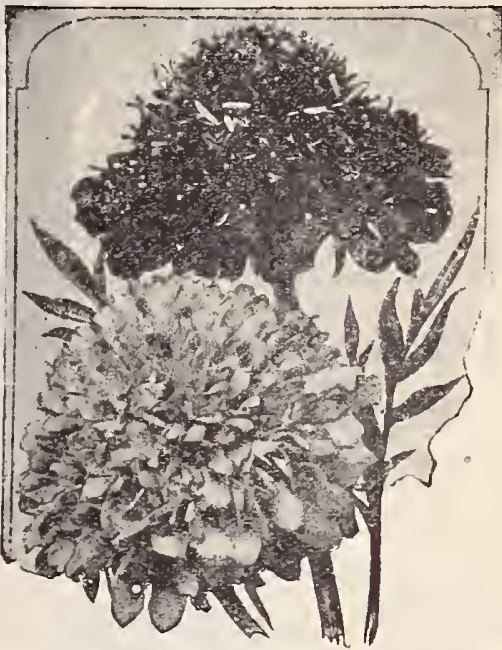

Royal Purple. Iarge-flowered, double, Color rich claret

Hardy Scabiosa. Caucasica. One of the hest of the har-

heautiful soft lilac color and are borne on long stems. They are exceed ingly charming as cut flowers. The plants begin to bloom in June and continue throughout the season.

\section{THUNBERGIA "Black-Eyed Susan"}

One of the best trailing plants for veranda boxes, vases, etc. Neat, compact growth. The pretty lowers, an inch in diameter, are white, huff or yellow, with hlack eye. Mixed Colors.

\section{VINCA ROSEA Madagascar Periwinkle}

Bedding or pot plants with glossy deep green leaves and hright, Myrtle-like fowers. Easily grown from seed and bloom continuously. Annual. One foot. Rose and White. Mixed.

\section{VICK'S VERBENAS}

Unrivaled as low growing beddirg plants. The following are realiy the only varieties of merit that are imported into this country

Very few plants will make such a gorgeous display during the summer momths as the Verbenas, or furnish uore flowers for cuting. Siart seel in the house or under glass early in the spring, and tramspiant after three or four inches of growth. Good healthy plants can be prociured reaclily from seed. They flower in July, and continue strong and healihy until after severe frosts Auricula-Flowered or White-Eyed. Mixed.colors . . . . . . . . . 10 Strined. Excellent flowers, with Carnation-lilie strines. Scarlet. Brightcst scarlet. Quite true

Ture White. Ouite true from seed.

rlue. Shades of hlue and purple

Ynllow. Pale prmrose yellow. .

Pink

Purplish Violet. with large white center

Fpmena hyhrifla. Extra large flowers, fine mixed colors, choice seed, saved only from the most beautiful named flowers, ounce, $\$ 2.50$.

Mixed colors ..., , , , , , , , , , , , , . 5 


\section{ZINNIAS}

The Zinnia is prized for its brilliant colors, for the size and perfection of its flowers, for its sturdy growth, and for the associations connected with it as an old time favorite. Seed sown in the open ground will produce strong plants, which will thrive and bloom from early summer until killed by late frosts. Set plauts from twelve to eighteen inches a part. If the plants are crowded tbe flowers will be small and imperfect. The young plants can be easily transplanted if desired.

\section{Giant-Flower- ing Double}

\section{Plants of vigorous growth, about three} feet high, bearing profusely their perfectlyformed double flowers, from four to five inches in diameter.

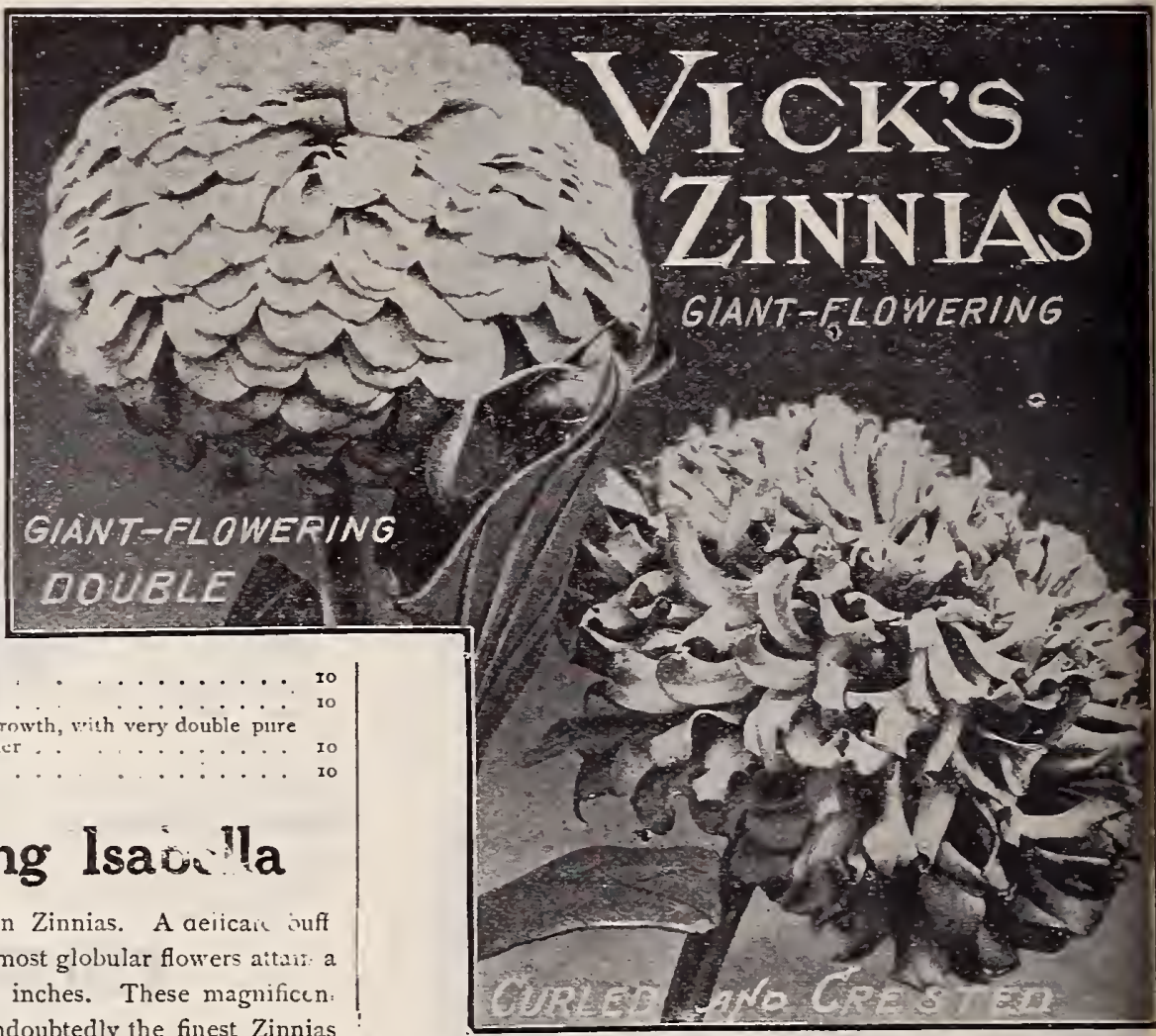

flowers, in pale salmon-yellow, are undoubtedly the finest Zinnias yet introduced. Packet ........... I5

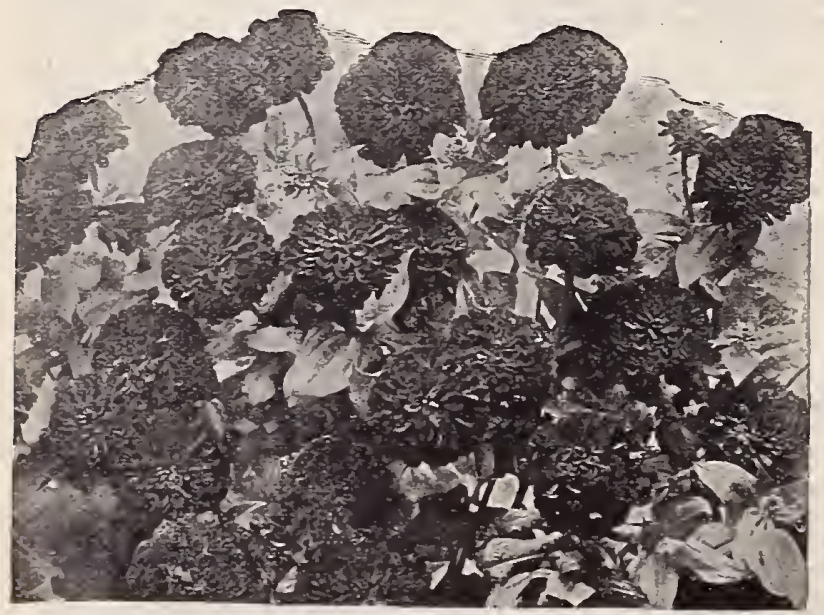

TINNIA, FIRF KINC

\section{Dwarf Zinnia Fire King}

The plants of Fire King grow from iwelve to eigheen inchc: ir heiaht The flowers are very deep scarlet, three to four inches in diameter, ano perfectly double. Nothing could exceed in brilliancy a bed of Fire King Zinnias. Packet.

\section{Large Flowering Double}

Separate Colors-lilac, purple, scarlet, rose, crimson, orange, yellow,

One packet of each of the above eight varieties for 30 cents. All colors mixed, ounce, 5. cents

Curled and Crested. A beautiful strain of this popular plant, showing on each plant from $x 00$ to 200 large double flowers, the perals being crested, twisted and curled into graceful and most fantastic forms. The colors comprise all the beautiful shades charactei "stic of the Zinnia

\section{Vick's Zinnia Collection}

As the summer is drawing to a close we are glad to greet our sturdy friend the Zinnia. „T bere is something reliable and cheering about the big, solid, double flowers and the elear, brilliant colors. Our Zinnia seed is produced by the most'skillful seed growers in Europe, and is absolutely the best that money can buy 17 e are sure that an who purchase the collection in separate colors will be more than pleased with their investment,

\section{Large Flowering Double Eight Separate Colors}

Lilac, purple, scarlet. ruse, crimson, orange, yellow, white, $\{30$ cents WALLFLOWER

Deliciously fragrant and splendid for cutting. The perennial Wallfower needs protection in the North.

Perennial. (half hardy) fine mixed colors, double

Annual. Flowering first season; fine mixed colors; single. 


\section{EVERLASTINGS}

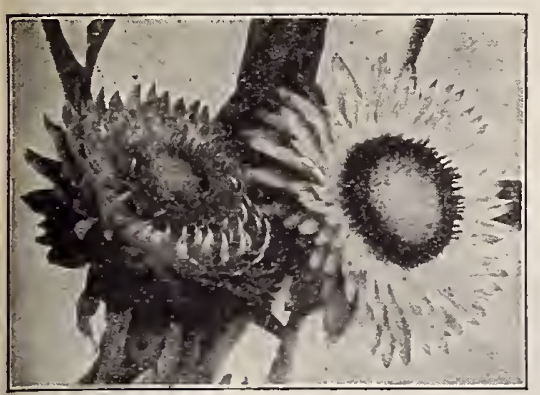

HELICHRYSUM
Gathered as the blossoms are opening and dried in a cool shady place these "fadeless flowers" will remain bright and beautiful a!l winter, and $u n t i l$ another season of outdoor flowers.

Acroclinium.Beautiful and free flower- Bright rose a is is lix 30 cents....

Globe Amaranth G omphrena. Pretty clover-like fowers. Mixed

colors. Ounce, 20 cents. The pretty pink or white flowers retain their grace and beauty when dried. Mixed colors. . . . . . . . . Straw Flower. Helichrysum. Large double flowers of many colors, including bright reds and yellows. Mixed colors...........

\section{Seeds of Tender Plants}

Most of the plants in this department come from a warm, moist climate, so we must supply similar conditions a rtificially. To do this without a greenhouse, sow the seeds in boxes or large pots : make a compost of three parts rotted sod and one part fine sand; this makes a rich soil that will not bake. Sow the seed very thin on the surface, then sift a little fine earth over it, and water gently through a fine sprayer; lay a piece of glass over the top, and put the boxes or pots where they may have ordinary warmth and ligbt. but no direct sunlight. When the plants are up remove the glass, or they will become mouldy and decay near the surface of the ground. As soon as they have made two leaves, transplant carefully into another box or pot of similar soil, set in a shady place for a few days, and water very sparingly. When somewbat established, remove them to the light.

Abutilon. Chinese Bell-Flower or Flowering Maple. A well known greenhouse shrub which will bloom freely with very common treatment. Seeds sown any time before A pril in a temperature of alront 6 odegrees, will produce strong flowering plants the first season. Finest varieties mixed.

Begonia Rex-Diadema. This seed has been saved from the largest and finest collection in Europe, and contains all the latest varieties. . . .

Calceolaria. The Calceolarias are very beautiful and popular plants, producing masses of peculiar pucket-shaped, striped, blotcbed, and variegated flowers. They make gorgeous plants for greenbouse or window.

hybrida grandiflora. Large-flowered, self-colored, rich and beautiful; saved from finest collection. .

Cineraria. Brilliant colors, compact habit and easily grown.

Hybrida. Choice mixed .................. 25

Hybrida grandiflora. From the largest flowered prize varieties . . $5^{\circ}$

Coleus. Remarkable for the brilliant colors of the foliage. Mixed seeds from the choicest sorts . . . . . . . . . . . . .

Cyclamen Persicum giganteum. Choice strain, large flowers, rich

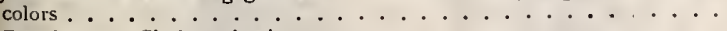

Persicum. Choice mixed . . . . . . . . . . . . ro

Geranium. Fine mixed

Choicest fancy varieties, Lady Washington, mixed sorts. . . . . 25

Gloxinia hybrida. Best quality; from choice show flowers ...... 25

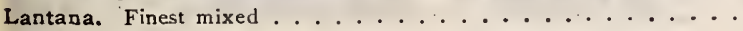

Linaria Cymbalaria, Kenilworth Ivy. Lavender and purple. .

Oxalis floribunda. Fine for baskets or pots. White and pink mixed .

Passiflora cœrulea. The hardiest Passion Flower . . . . . . . .

Primula Sinensis. Chinese Primrose. Cboicest fringed varieties. mi*ed

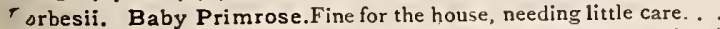
ebconica grandiflora. Prnfuse bloomer, bearing on long stems heads with 10 to 15 fluwers. Mixed varieties. . . . . . . . .

Schizanthus Wisetonensis. As a pot plant this has hardly a superior. It is literally covereu with small orcbid-like flowers and remains in bloom from four to six weeks for boquets and floral decorations Sow in February and keep in a moist

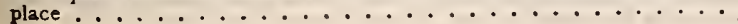

\section{ORNAMENTAL GRASSES Hardy Grasses}

Giant Reed. Arundo Donax variegata. 4 to 7 feet. Stately Bamboolike plant. The abundant leaves elegannly striped with creamy white.

For lawns, borders of streams, etc. - - Erianthus Ravenna. 4 to 7 feet. The graceful clumps are surmounted by bandsome plumes, which are much used for winter decoration

Quaking Grass. Briza maxima. Handsome for winter bouquets. .

\section{Annual Grasses}

Cloud Grass. Agrostis nebulosa. The delicate, mist-like panicles, elegant for bouquets

Fountain Grass. Pennisetum longistylum. 2 feet. Long slender Purple Fountain Grass. Pennisetum Ruppellianum. 3 leet. The purplish p'umes beautiful for bouquets and unequalled as a border for beds of tall plants.

Job's Tears. Coix Lacryma-Jobi. Two feet, Corn-like leaves, Grown for the bead-like fruit. Ounce, 20 cents.

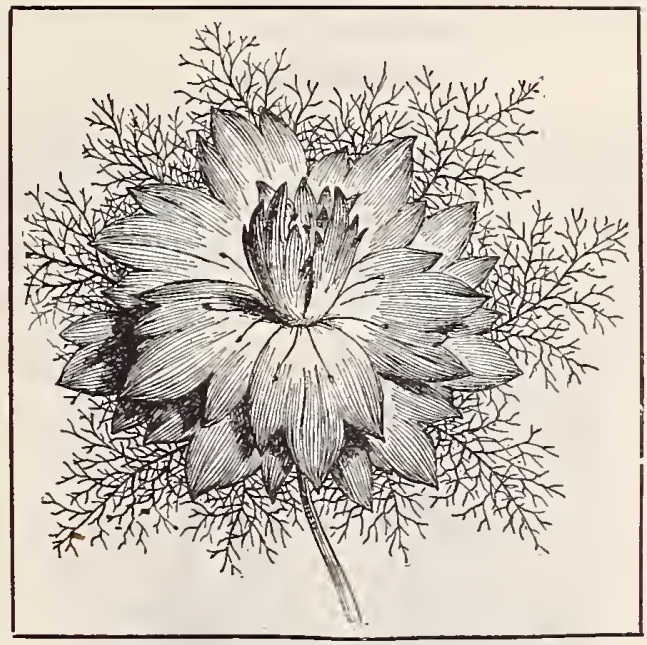

\section{NIGELLA}

Love-in-a-Mist, Devil-in-a-Bush and Fennel Flower are names given to this pretty, interesting and easily grown annual. The foliage is very fine and feathery, and the showy flowers, mostly in shades of blue, are surrounded by a burder resembling green lace. Interesting in the garden and fine for cutting Twelve to fifteen inches. Mixed cclors.

\section{MIMULUS}

The Mimulus, or Monkey Flowers (named from the resemblance of the corolla to a mask or face), are beautiful tender plants witb almost transparent branches Fine for baskets, vases, and bouse culture, and do well planted out where they will be somewbat shaded. Perennial, but bloom the first season.

Hybridus tigrinus grandiflorus. Flowers beautifully spotted.... 10 Moschatus. Musk Plant.................. . . . All sorts mixed

\section{NICOTIANA}

Affinis. One of the best Nicotianas we have ever grown. 'The plant attains the height of three feet, and at evening and early morning is covered witb deliciously-scented, large, white flowers. Easily grown from seed, and cuttings rooted in September will bloom freely in the winter. . .

sanderce. The whole plant, from base to summit, is laden with flowers of an intensely glowing rosy carmine color, making it incomparably beautiful and charming. Easily grown............ The very long pendulous flowers are delicately fragrant, and are borne in great profusion. A bold and striking plant. . . . . . . . . 


\section{Gardy Plants and Bulbs}

For a complete list of the Best Hardy Plants for the garden you are referred to our Catalogue,

"Hardy Plants Old and New," in which are Illustrated and described Hardy Plants, Roses, Shrubs and Climbers. A copy will be mailed free on request.

\section{ACHILLEA}

The Pearl. The hlossoms are of purest white, and so large that they resemble a Pompon Chrysanthemum. Hardy, and will thrive in almost any situation. Very desirable for the garden or cemetery. Blooms nearly the whol season, Each, 20 cents : three for 50 cents.

Millefolium roseum. Foliage very finley cut; flowers pink. A continious hloomer. Each, 20 cents; two for 30 cents.

Tomentosum. Bright yellow flowers. Very fine for rockeries. Each, 20 cents; two for 30 cents.

\section{ALYSSUM}

Saxatile compractum. Flowers golden yellow, very showy. Fine for rock. ery or edging. Each, 20 cents; dozen, $\$ 2.00$.

\section{ANEMONE}

Whirlwind. This double variety has the haoit, and all the other good qualities of the Single $W$ bite Japan Anemone, with the additional ones of greater hardiness and more lasting blooms. "The flowers are two and one-half to three inches across, and have several row.s of white sepals. The plants grow from two and one-half to three feet in height. Kach, 25 cents: dozen, $\$ 2,50$ Queen Charlotte. Early-flowering, vigorous grower. Begins fowezing in August, and continues until Novemher, becoming more attracuve each day. Flowers semi-double, hroad, perfectly formed, and of a deinghtful shade of silvery pink. Each, 25 cents; dozen, \$2.50.

Taponica Alba. Flowers pure white with yellow center, single. Each, 20 cents; dozen, $\$ 2.00$.

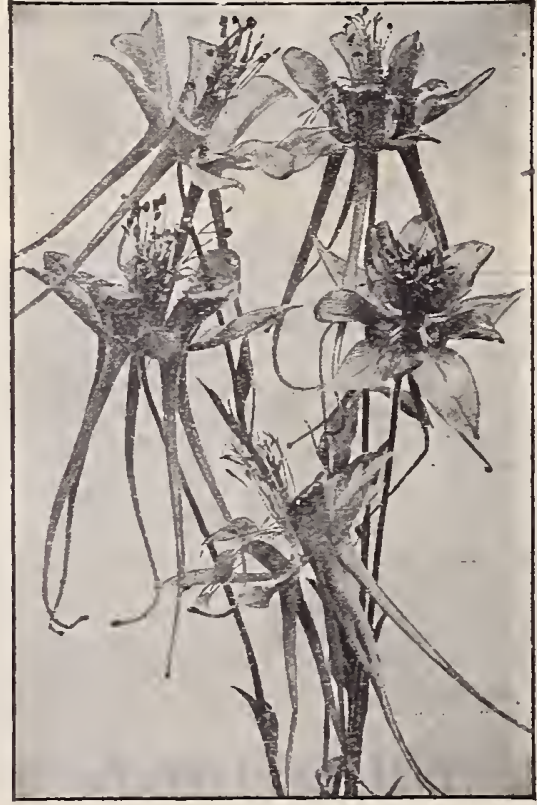

\section{AQUILEGIA}

Each, 20 cents: dozen, $\$ 2,00$.

Chrysantha. The heautiful golden-yellow Columbine.

Corulea. The true Rocky IIountain Columbine Flowers azure blue and Skinneri. Scarlet and yellow.

Ersikine Park Hybrids. Peautiful hybrids. A fine selection of the most popular color

Single Mixed. All colors in a fine mixture.

Double Mixed. Flowers very large, full and double.

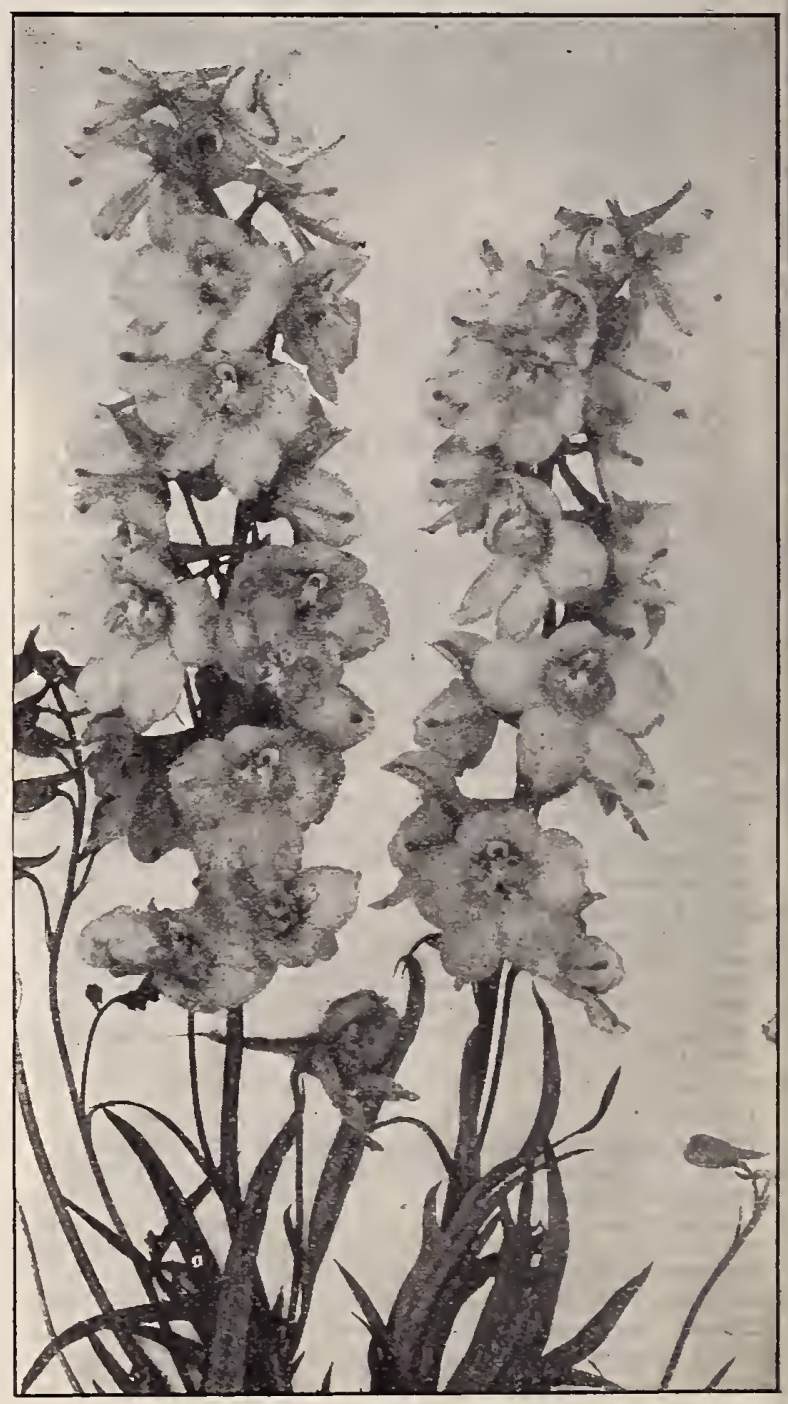

\section{DELPHINIUM, Larkspur}

Valuable plants for the herbaceous garden, that will give perfect satisfaction to any one who grows them. Their long spikes of flowers are produced from June until frost.

Formosum. The finest hlue known among our hardy plants. Each, 2ocents. Bee Larkspur. Remarkahle and interesting, the petals being folded up in the center of each flower so as to resemhle a hee. Flowers lighter than Delphinium formosum. Each, 20 cents.

Sinensis. Foliage delicately cut. Large panicles of handsome flowers vary ing in color from white to blue. Each, 20 cents; dozen, \$2.00. 


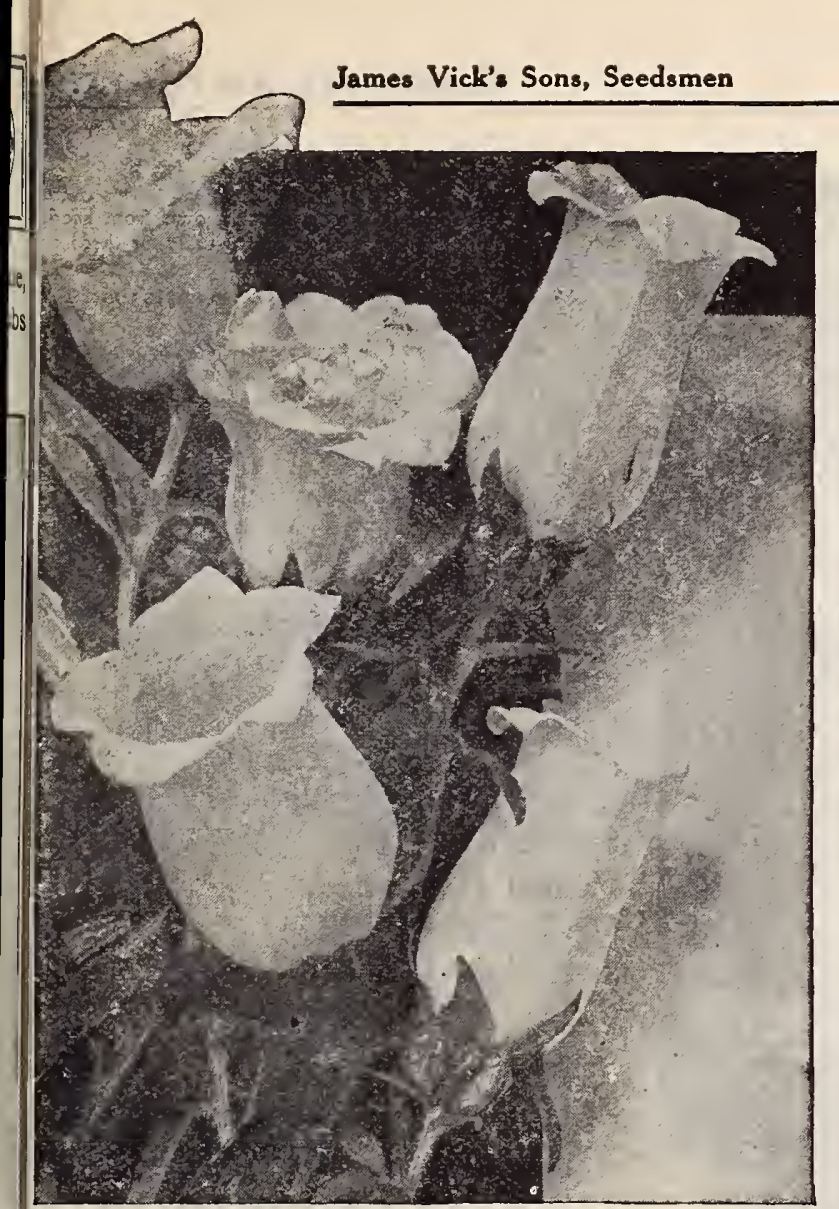

CANTERBURY BELL, CAMPANULA MEDIUM

\section{CAMPANULA, Bell Flower}

Each, 20 cents ; dozen, $\$ 2.00$

Carpatica. Very dwarf habit, flowers blue; in bloom all summer.

Carpatica alba. A white-flowered form of carpatica.

Persicifolia. Grows about one and one-half feet high and produces a great number of blue flowers in loose clusters from June to Uctober.

Persicifolia alba. A white form of tbe above.

Pyramidalis. A most attractive plant for the border, a single plant producing hundreds of flowers, forming a perfect pyramid, covered with large blue flowers. Height from four to five feet.

Pyramidalis alba. Same habit as Pyramidalis, but the flowers are white. Medium. Better known as Canterbury Bells. Our stock has been grown from the finest strain of seed.

\section{BLEEDING HEART}

Dicentra spectabilis. Bears heart-shaped deep pink flowers, a dozell or more being borne in a graceful drooping raceme, a foot in length. Each, 30 cents.

\section{BOLTONIA}

Among the showiest of our native hardy perennials. Attain a beight of four to five feet, with single aster-like flowers in large clusters. Very freeflowering.

Asteroides. Pure wbite. Each, 20 cents; dozen, \$2.00.

Latisquama. Lavender Pink. Each, zo cents; dozen, $\$ 2 . \infty$.

\section{CHRYSANTHEMUMS}

For hardy Chrysanthemums see page go.

\section{CLEMATIS}

Davidiana. A vigorons, hardy plant, two to four feet bigh, flowers bell-shaped, deep lavender or violet in color, very fragrant, and produced in clusters in great profusion. Strong plants, each, zo cents; dozen, $\$ 2 . \infty$.

\section{COREOPSIS}

Lanceolata. The flowers are two to three incbes in diameter, a rich golden yellow, of graceful form on long slender stems, and invaluable for cutting. In bloom from June until October. Each, 20 cents; dozen, $\$ 2 . \infty$.

\section{CORNFLOWER ASTER, Stokesia Cyanea}

Valuable native hardy plant of easy culture. Large, handsome flowers of lavender blue, borne profusely from July until frost. Each, wo cents.

\section{ERIANTHUS}

Ravennae. Hardy Pampas Grass. Grows from $g$ to 12 feet high, frequently throwing up from 30 to 50 flower spikes. Each, I5 cents ; dozen, $\$ .1 .50$

\section{EULALIA}

Handsome, tall, ornamental grasses for the open lawn, or for clumps in the borders of shrubbery. Leaves beautifully varigated.

Japonica zebrina. Stripe or marking is across the leaf instead of lengthwise. Japonica variegata. Leaves beautifully striped lengthwise.

Gracilling univittata. The most beautiful of all the Eulalias. Foliage nar. row, dark green, witb a silvery white midrib.

Each, 20 cents ; one plant each of above three for 50 cents.

\section{FORGET-ME-NOT}

Myosotis palustris. 'The trte perennial Forget-me-not. A variety that is alway's in flower. Each, 15 cents; dozen, \$1.50.

\section{FOXGLOVE, Digitalis}

A highly ornamental pereunial plant of stately growth. Excellent for planting in shrubberies with other hardy plants. The racemes of spotted, hoodshaped flowers are often two feet in length. Each, 20 cents.

\section{GAILLARDIA}

Grandiflora. Among the most attractive and effective of our hardy perennlal plants. Will thrive in almost any position or in any soil. One mass of bloom from June till autumn. The gorgeous flowers, lwo to three inches in diameter, are borne on long stems. Excellent for cutting. Each, 20 cents.

\section{GYPSOPHILA, Baby Breath}

Paniculata. Gypiophilas are valuable for bouquet making, either green or dried. I hey are very graceful and easily cultivated. Should be in every garden. Flowers white. Each, 20 cents.

\section{HARDY ASTERS, Michaelmas Daisy}

The hardy Asters produce an abundance of bloom in the fall, when other flowers are scarce. Each, 20 cents; dozen, \$2.00.

Lady Trevelyan. Pure white. Dwarf. Pyramidalis. Ligbt blue. Dwarf. White Queen. Pure white. 'I'all.

\section{HELENIUM, Sneeze Weed}

Autunnale superbum. Valued for its profusion of golden yellow flowers. Long season of bloon and useful for cutting. Each, 20 cents; doz., $\$ 2.00$.

\section{HELIANTHUS, Hardy Sunflower}

The tall plants are covered with bloom in fall or late summer and the flowers are very desirable for cutting. Each, Io cents; dozen, \$1.50.

Helianthus latæfrons. Plant of distinct habit, forming a pyramid of lovely flowers and foliage. Flowers golden yellow, single,

Maximilliana. (iolden yellow, wilh reddish brown center. Single.

Multifiorus F1. Pl. Double Hardy Sunflower. Large, double Dahlialike golden-yeliow flowers in great profusion during July and Augist ; 4 feet.

Rigidus. Of fine uprinht habit of growth. Flowers light yellow witb maroon center. Three feet.

Miss Mellish. Fiowers in September and Uctober. Grows about six feet high, with large, single golden-yellow flowers.

\section{HERBS}

English Lavender. Each, 15 cents; two for 25 cents.

Mammoth Broad-Leaved Sage. Each, 15 cents; two for 25 cents.

\section{HIBISCUS, Marsh Mallow}

\section{Each, 20 cents; two for 35 cents.}

Strong plants from three to five feet in height. The large flowers from four to eight inches in diameter. Grow especially well in moist situations.

Crimson Eye. Pure white, with a velvety crimson center.

Militaris. Delicate flesh-pink flowers, tinged with deeper color toward the center.

Moscheutos, Light rose, with dark center. Beautiful. 
If there is anything more beautiful or graceful than the Japanese or the German Iris, it has nut been brought to our attention. Lovers of fine fluwers rightly set a ligh value on the exquisite beauty of the orchid; but in our opinion some of the Iris equal if not surpass the orchid in beauty of form and delicacy of coloring.

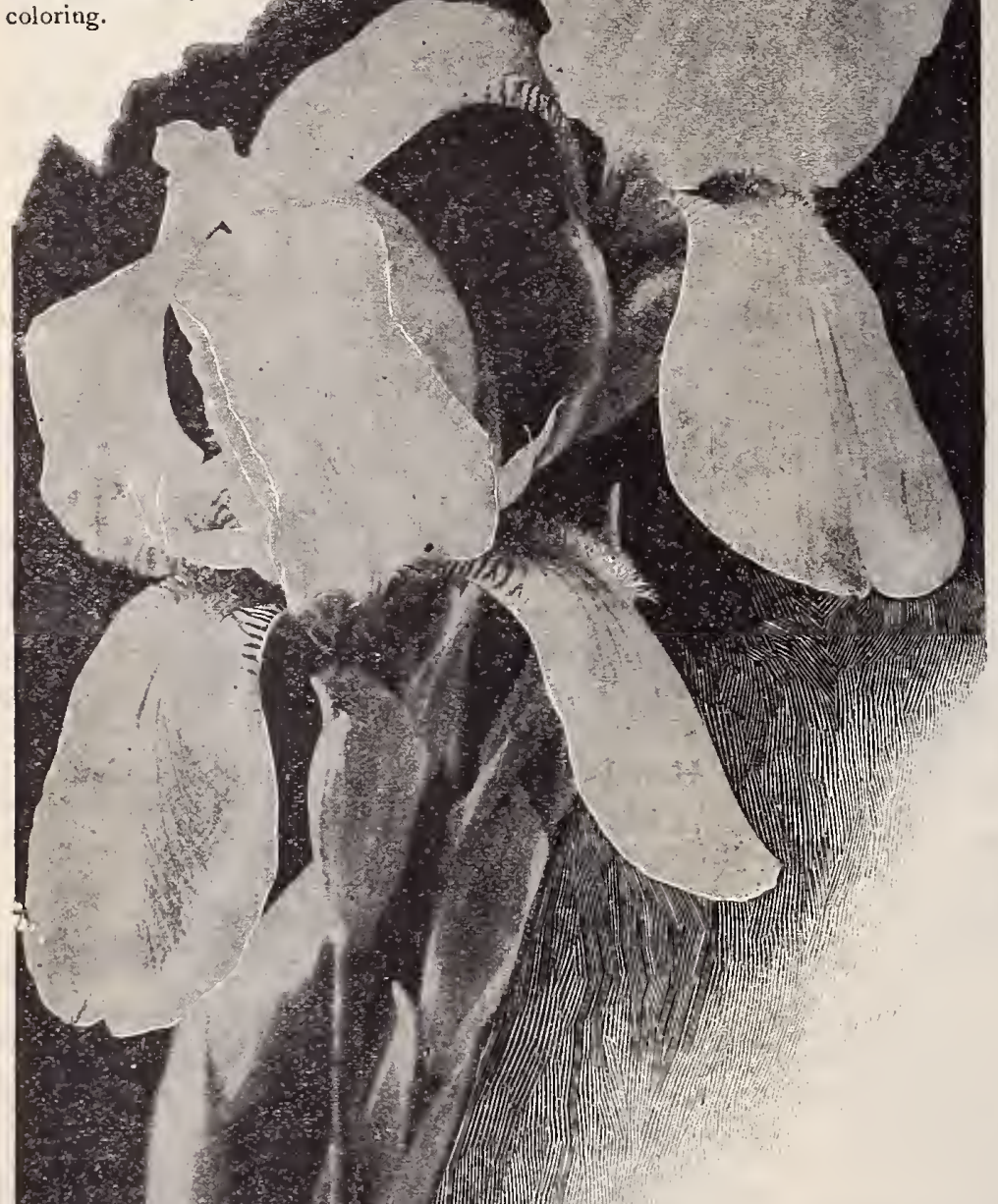

\section{HOLLYHOCK}

We have excellent healthy plants, grown from seed, that will flower the first summer and usually for three or four summers thereafter.

Double, Assorted colors. Each, 20 cents; six for $\$ 1,00$.

Allegheny. Fringed Perpetual-Blooming. A great improvement in Hollyhocks. The flowers come single, semi-double aud double. Each, 20 cents; six for $\$ 1.00$

\section{IBERIS, Evergreen Candytuft}

Sempervirens. Produces innumerable pure white flowers during April and May. Each, 15 cents; dozen, $\$ 1.50$

\section{IRIS}

\section{GERMAN IRIS, Fleur-de-lis}

Perfectly hardy. They bloom in May and June, when there is alway's a scarcity of flowers. Plant three inches deep. Each, 20 cents; six for $\$ 1.00$.

Celeste. Ijight Llue.

Gesneriana. White and lavender.

Madame Chareau. White.

Madcap. Lavender and purple.

Souvenir. Old gold and purple, tall grower.

Pharaon. Blue, shaded rose culor.

Pallida Dalmatica. Noblest of all the Iris high, with leaves two inches widamily, three to four feet long. I he flowers are sky-blue in color and very fragrant Each, 50 cents; dozen, $\$ 5.00$.

\section{JAPAN IRIS}

The flowers of the Japan Iris are of the richest colors, ranging from white to purple, with delicate markings and veinings, and quite different in form from those of the German Iris, being much flatter and larger. Named varieties, all double. Each, 25 cents; dozen, $\$ 2.50$. Blue Danube. Deep indigo blue, violet shadings. Gold Bound. Pure white.

Mars. Reddish purple, striped and blotched white. Mahogany. Dark red, shaded maroon.

Pyramid. Lilac blue, veined white in center of each petal. spotted Beauty. White spotted with violet irimson.

\section{SIBERIAN IRIS}

Sibirica. Forms strong. free blooming clumps, three feet high. Flowers light biute, veined with violet. Each, 20 cents; dozen, $\$ 2.00$.

\section{LOBELIA, Cardinal Flower}

Cardinalis. Flowers rich fiery cardinal color. Each, 20 cents; dozen, $\$ 2.00$.

\section{LUPINUS, Lupine}

Polyphyllus. Strong plants, with long spikes of pealike flowers in early summer. Nixed colors. Each, 20 cents; dozen, $\$ 2.00$.

\section{LYCHNIS}

Chalcedonica, Maltese Cross, Jerusalem Cross. Prodices large heads of brilliant scarlet flowers. A gem for cut flowers. Each, I5 cents; dozen, $\$ 1.50$. Viscaria splendens, fi. pl. Forms a dense tuft of evergrecn foliage. Flowers double, a deep red, very fragrant. Each 20 cents; dozen, \$2.00.

\section{LYSIMACHIA, Loose Strife}

Clethroides. A fine hardy plant growing about two feet high, with long, recurved spikes of pure white flowers, from July to September. Each, 15 cents; dozen, $\$ 1.50$.

\section{MONARDA DIDYMA}

An exceptionally fine hardy perennial for planting among bulbs or in a mixed border. The plant grows about $2^{\prime} ;$ feet hign. branching freely, and bears multitudes of bright red, showy flowers, which are surpassed in intensity of color only by the Cardinal flower. For a mass of eolor it is very striking. Thrives well in the shade. Each, 15 cents; two for 25 cents.

Flowers of the beautiful German IRIS

\section{PENTSTEMON}

Most useful hardy perennial, blooming from June until autumn. Very fine,

Coerulea. Flowers Elue. Each, 20 cents; dozen, $\$ 2.00$, 


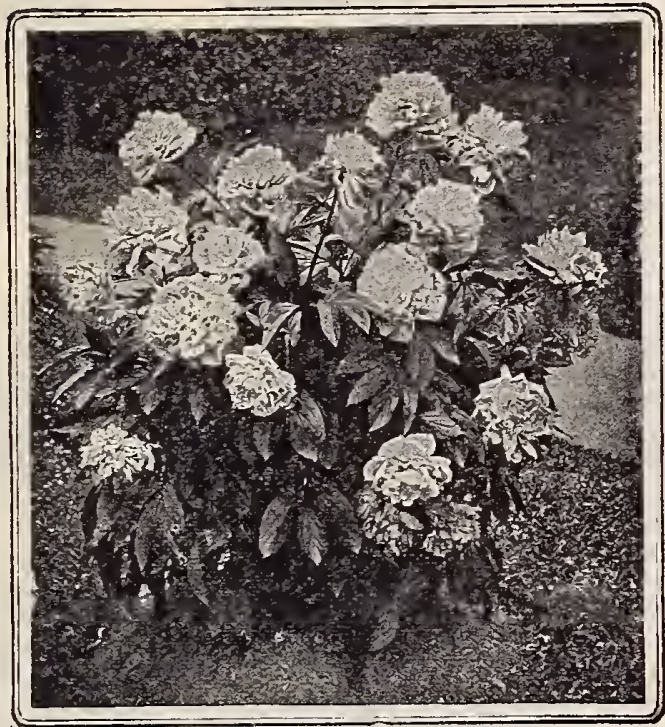

\section{PEONIES}

Extra fine roots, each, 30 cents; dozen, \$3.00; except where noted.

The Chinese Peonies are desirable on account of their large size, fine colors and profuse blooming. They are periect'y hardy, and will succeed on asy ground unless so wet that the water will lie on the surface in the winter and spring. May be planted either in the autumn or spring.

Amabalis lilacina. Blush, with center of cream and white. Very fine.

Buyckii. Rose, with celiter of salmon and rose.

Duchess de Nemours. White, with sulphur shading in center. Fragrant. Elegantissima. Rose, with center of cream and rose.

Festiva alba. White, one of the hest.

Fringed Leaf Peony. Tenuifolia flore pleno. Foliare graceful and finely cut. Fluvers fragrant; brilliant double dark crimson, and the earliest of all Peonies. Each, 50 cents; two for go cents.

Grandiflora carnea plena. Very large, fragrant and early. Outside pink. center flesh color.

Lutesiana. Blush, with center white.

Nivalet. Fine shade of pink.

Officinalis rubra. The old fashioned crimson Peony.

Rich, deep crimson; very early and one of the brightest.

Pulcherrima. Rose pink.

Reine des Francaises. Blush, with white center. Very early and fragrant. Roi Guillaume. Light rose.

Rosea plenissima superba. Rose, with pink center. Full, massive flower Smitzii. Single. Crimson.

Var.egata plenissima. Rose and pink.

\section{SIX SUPERB PEONIES}

The Set of Six for $\$ 2.25$

Achille. Light flesh-colored pink, changing to hlush white, with an occasional creamy spot. Each, 35 cents.

Delache. Tall ; immense globular heads of crimson maroon. Each, 35 cents. Festiva Maxima. Enormous full double bloum. Color, pure white widh ail occasional carmine spot. Each, 50 cents.

Hercules. A splendid white and rose pink variety; very large flowers. Anemone-shaped. Each, 50 cents.

Lady Lenora Bramwell. Soft siivery pink. Each, 35 cents.

Rose a superba. Large convex bloom; very full, light pink. Each, 50 cents.

\section{PHYSOSTEGIA, False Dragon-Head}

One of the most beautiful of our summer flowering perennials, bearing long spikes of tubular shaped flowers. Each, 20 cents;-dozen, \$2.00.

Virginica. A delicate pink. Four feet. Virglnica alba. White. Two feet.

\section{PAPAVER, Poppy}

Orientale. Oriental Poppy. Immense flowers of brilliant scarlet.

Nudicaule. Iceland Puppy. Exquisite, silky flowers; fine for cutting. White, yellow and orange.

Mixed colors. Each, 20 cents; dozen, $\$ 2 . \infty$.

\section{HARDY PINKS}

These pinks are perfectly hardy, and will remain in the open ground all winter wilhont protection. Each, 20 cents ; two for 30 cents; dozen, $\$ 1.50$. Comet. A fine sliade of red; flowers double, clove scented.

Her Majesty. Flowers very large, friuged, very double, and pure white.

Fragrance delicious, clove scent.d. Long stiff stems support the flowers.

Souvenir de salle. Soft rosy pink; large as a carnation; reautifully forined and very double.

White Reserve. A nicely fringed white. Always in bloom.

\section{PYRETHRUM}

Roseum. Peautiful, large, daisy-like flowers of various colors. Splendid for cutuing and very long season ol bivon. Each, I5 cents; dozen, $\$ 1.50$.

\section{PLATYCODON, Bell Flower}

Crandiflorum. Chinese Bell Flower.. Flowers, three inches in diam elur, produced the entire seasoll. Blue or white. Each, 15 cents; dozen, \$1.50.

\section{PERENNIAL PHLOX}

With Perennial Phlox a show of brilliant fluwers can he had from June un November, as they are perpetual bloomers. Perfectly hardy.

Strong field-grown plants. Each, 20 cents; dozen, $\$ 2.00$.

Coquelicot. Bright scarlet.

Cyrano. Largetruss of pink fluwers.

Esclamonde. Rosy lilac, shaded

white; large purple center wih

whice halo.

Faust. Bright rose.

Heroine. Beautiful bluish purple.

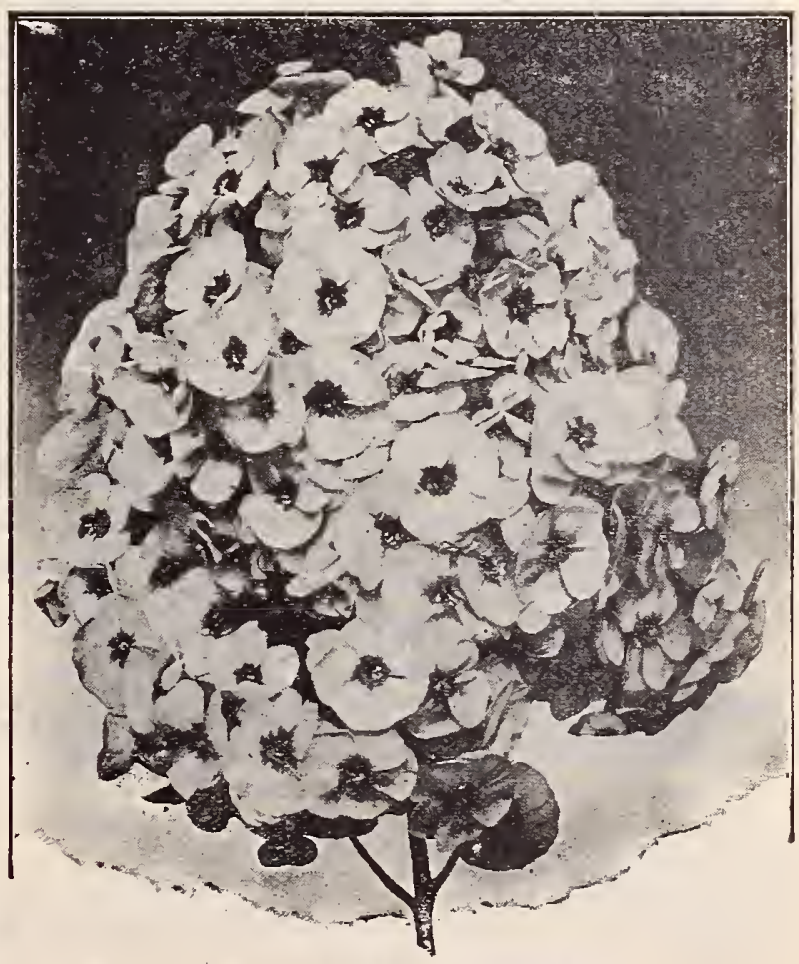

PERENNIAL PHLOX
M. Bezanson. Fiery crimson, vel vely pusple tye.

virity. The best pure white.

Richard Wallace. Pure white with distinct violet eye:

Rosetta. Deep rosy crimson violet. Sir Edwin Landseer. Brillian crimson. 


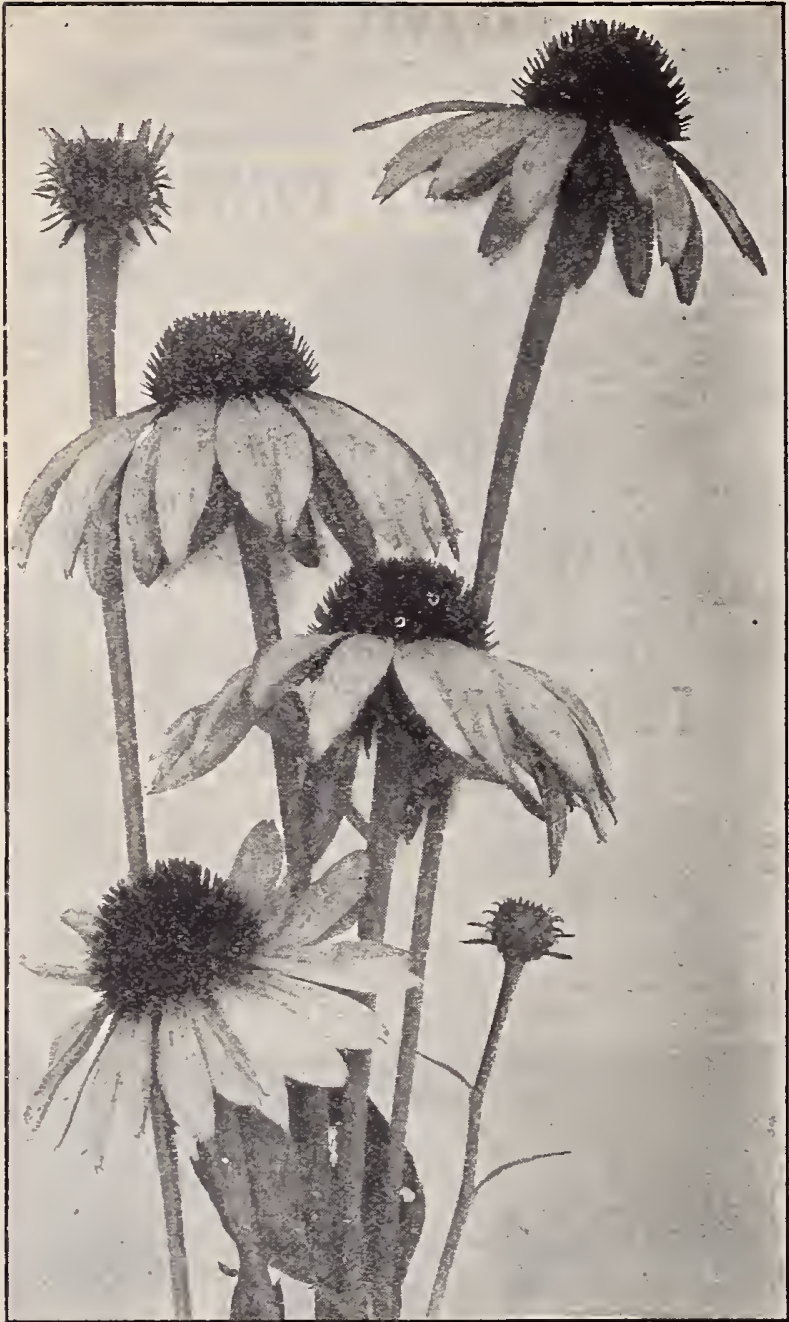

RUDBECKIA PURPUREA

\section{RUDBECKIA}

COLDEN GLOW. Rudbeckia laciniata flore pleno. A beautiful hardy perenniat, eight feet high, blooming from July to September. Flowers double, deep golden yellow, borne on long stems, mitking it suitahle for cutting. One of the most effective decorative plants forgarden or lawn. Each, 20 cents; two for 30 cents; dozen, $\$ s .50$.

Newmani. Single, goldell yellow, with black center; grows about eighteen inches high. Each, 20 cents; dozen, $\$ 2,00$,

Purpurea. Flowers reddish purple. Two to three feet high. Beautiful and lasing as a cut flower. Exch, 20 cents; dozen, $\$ 2.00$.

\section{SALVIA}

Each, 20 cents; dozen, $\$ 2.00$

Azurea grandiflora. A Kocliy Mountain species, growing two to three feet h.gh, yroducing during August and September pretty sky.blue flowers in the greatest profusion.

\section{SEDUM, Stonecrop}

Excellent flechy leaved plants for the rockery. Each, 15 cents; dozen, \$r.50. Album. Low-growing; prelty white flowers.

Acre. A pretiy species for rockwork; forms a neat green carpet.

Pulchrum. A low-growing variety. Flowers pink.

Spectabile, A strong upright grower, with heads of showy rose-colored flowers.

Telephium. The well-known "Live Forever." Flowers pink, spotted white.

\section{SCABIOSA}

Caucasica. One of the best hardy plants, with flowers of a beautiful solt lilac color. Blooms from June until tall. Each, 20 cents; dozen, $\$ 2.00$.

\section{SHASTA DAISY}

A fine hardy perennial. The flowers are pure wbite, witb a bright yellow center, average about four inches in diameter and are borne on long, stiff, wiry stems. Valuable for cutting, remaining fresb for two weeks or more. Each, 20 cents; dozen, \$2.00.

\section{HERBACEOUS SPIREAS}

Spiræa palmata elegans. A beautiful hardy, free-flowering plant, with sweet-scented white flowers and red anthers. a very pleasing and useful plant for cut flowers and excellent for hardy berbaceous borders. Fach, 20 cents; dozen, $\$ 2.00$

ARUNCUS. A grand variety three to five feet high, producing in June, long feathery panicles of white flowers. Each, 20 cents; dozen, $\$ 2.00$.

\section{SWEET WILLIAM, Dianthus barbatus}

Splendid old-fashioned perennial. Each, 20 cents; dozen, \$2.0o.

Double White.

Single White.

Dunnetti. Rich dark crimson.

Holborn Glory. Rich colors, each flower with center and border of white.

\section{VERONICA}

Spicata. An elegant border plant. Long slender spikes of deep blue flowers. Each, 20 cents ; dozen, \$2, $\infty$.

\section{YUCCA, Spanish Bayonet}

Filamentosa. Erect stately plant with sharp pointed leaves. Perfectly hardy. Flowers creainy white; bell-shaped. Each, 25 cents; dozen, \$2.50

\section{TRITOMA, Flame Flower}

Pfitzerii. The flower spikes, which are produced freely are of gigantic size, frequently four and one- half feet high, with beads of bloom over twelve inches long. They are a ricb orange-scarlet, shading to salmon-rose on the edge. Eacb, 25 cents; dozen, \$2.50.

Macowanii, A charming variety, very early to come into bloom, stems lon truss rather loose; color orange, scarlet and yellow. Eacb, 20 cents dozen $\$ 2.00$.

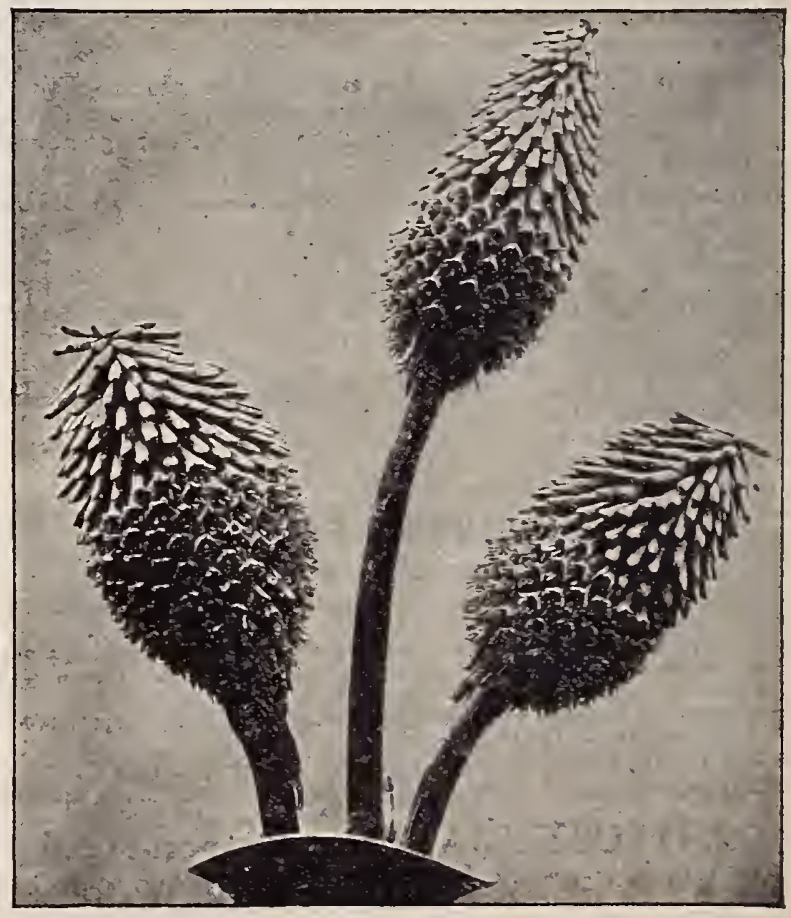

TRITOMA PFITZERII 

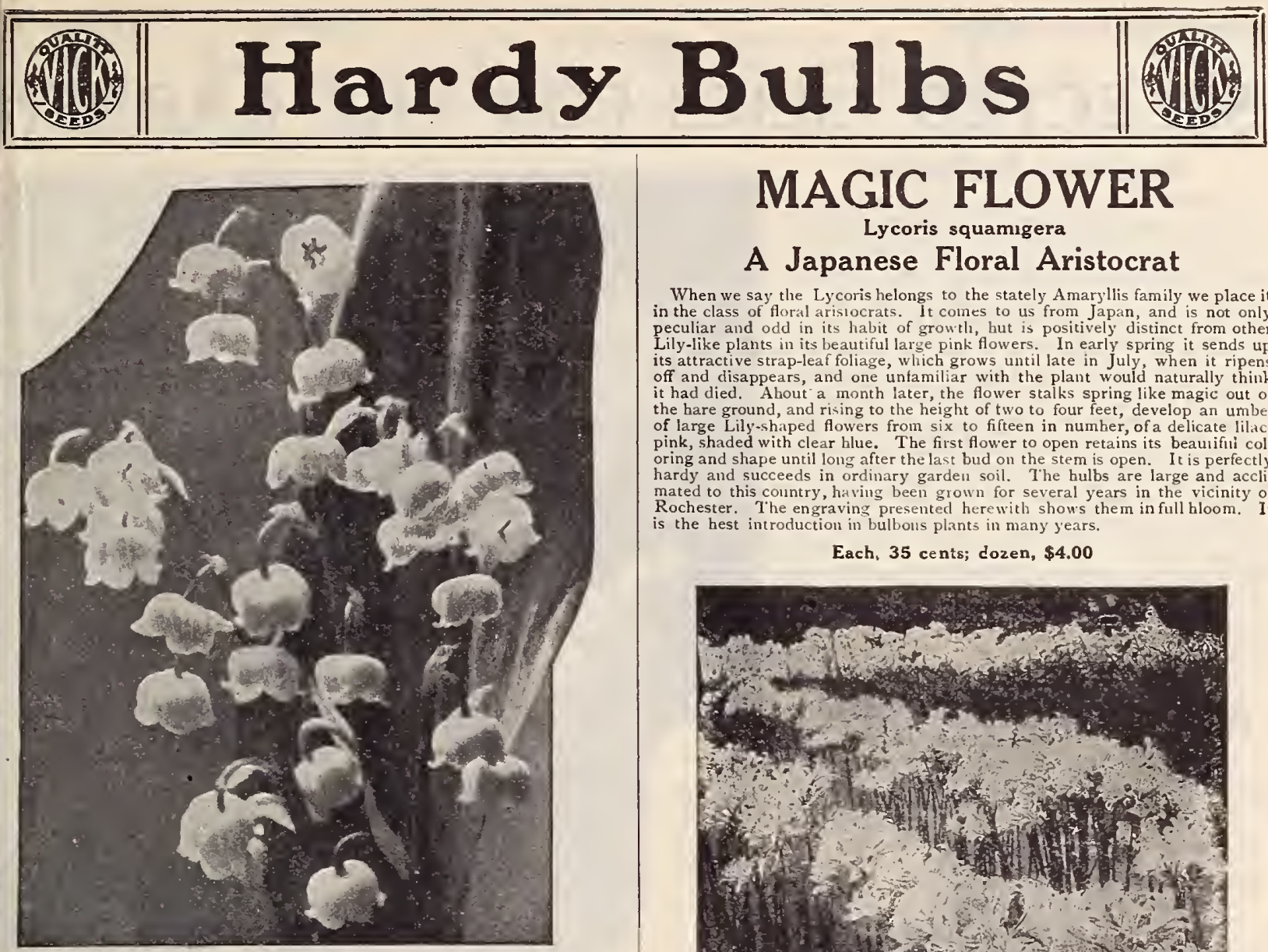

\section{MAGIC FLOWER}

\section{Lycoris squamigera}

\section{A Japanese Floral Aristocrat}

When we say the Lycoris helongs to the stately Amaryllis family we place it in the class of floral arisiocrats. It comes to us from Japan, and is not only peculiar and odd in its habit of growtls, hut is positively distinct from other Lily-like plants in its beautiful large pink flowers. In early spring it sends up its attractive strap-leaf foliage, which grows until late in July, when it ripens off and disappears, and one unfamiliar with the plant would naturally think it had died. Ahout a month later, the flower stalks spring like magic out of the hare ground, and rising to the height of two to four feet, develop an umbel of large Lily-shaped flowers from six to fifteen in number, of a delicate lilacpink, shaded with clear hlue. The first flower to open retains its beauifuil coloring and shape until long after the last bud on the stem is open. It is perfectly hardy and succeeds in ordinary garden soil. The hulbs are large and acclimated to this country, having been grown for several years in the vicinity of Rochester. The engraving presented herewitl shows them in full hloom. It is the hest introduction in bulbous plants in many years.

Each, 35 cents; dozen, $\$ 4.00$

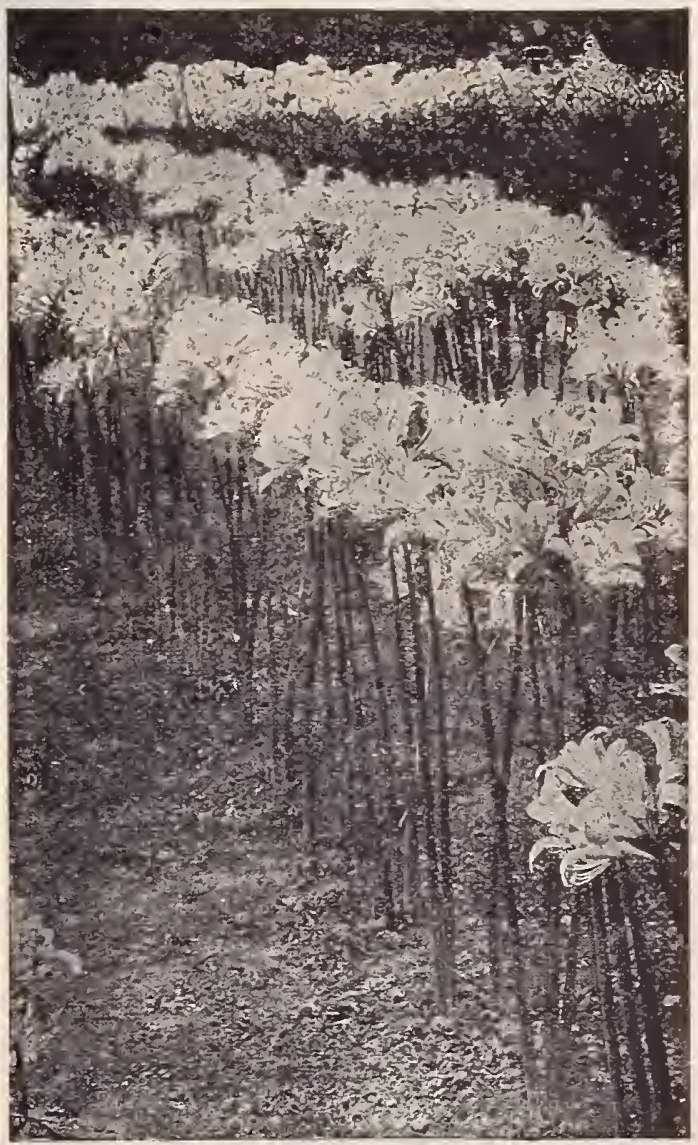

MAGIC FLOWER

\section{LILY OF THE VALLEY}

Hardy perennial. Sweet, delicate, and graceful. When planted out of doors set the pips six inches apart and two inches deep in a partialiy shaded place For house culture plant in pots, ahout one inch apart, in moss or sand, and water freely; then set the pots out of doors where they may freeze a day or two; after which bring them in doors, and after thawing, water freely and set in a sunny place in the window. Pips can be ordered in Decemher for house culture, or in spring or fall for garden culture. Pips, half dozen, 25 cents ; dozen, 40 cents; fifty, $\$ 1.40$. hundred, $\$ 2.50$.

\section{DAY LILIES}

The Day Lilies are superh autumn flowers, desirable for planting on the side of a lawn or at the edge of shrubbery. The Funkias do well in shade and are much prized on that account.

Funkia alba. White Day Lily. Broad, light green leaves, Flowers large, pure white; fragrant. Each, 20 cents; dozen, $\$ 2.00$.

Funkia Japonica. Light blue; narrow foliage. Each,20 cents; dozen, $\$ 2.00$. Funkia undulata media picta. Lavender. Foliage light green, heautifnily variegated with white. Each, 25 cents ; dozen, \$2.00. Lemon Lily. Hemerocaltis flava. A fine hardy plant, producing an
abundance of large, fragrant, golden yellow flowers. Each, 20 cents; dozen, $\$ 2, \infty$.

\section{One each of the above four sorts for 70 cents.}

Golden Day Lily. Hemerocallis aurantiaca major. One of the finest periectly hardy herhaceous plants. The plant is vigorous in habit; the foliage rises to a height of two feet, and is of a deep green. The flower spikes are strong, bearing as many as twelve flowers in succession, which are seven to eight inches across, of a rich orange-yellow, quite distınct. Each, 30 cents ; two for 50 cents. 


\section{SELECTED LILIES FOR THE GARDEN}

\section{Suggestions for Planting}

Plant the large Lily Bullis, like those of Auratum and Speciosum, eight or nine inches deep. Small bulbs, like those of Tenuifolium, Golden Gleam and Canadense, five or six inches deep. Many fail in this particular, setting the bulbs so near the surface that the frosts of winter almost throw them out of the soil. The Lily throws out roots from the stalk above the bulb, and these serve the double purpose of supplying nutriment to the plant and of bracing and sustaining in position the heavy weight of the blossoms. The soil for Lilies should be made rich with old, well-decayed manure,thoroughly incorporated with the soil; but fresh dressing must never be used, nor must any come in contact with the bulbs. They should be set on and surrounded by a layer of pure sand. When the ground freezes in the fall, apply a covering of stable litter or leaves, which may be forked in, in the spring, thus supplying enrichment to the soil, as well as preventing the ground from baling hard during the summer.

\section{Auratum The Gold-Banded}

A favorite variety for outside purposes for many years and no garden, however small, should be witbout it. Its ease of culture and magnificent flower make it one of the most desirable varieties of garden lilies. The delicate ivory color is thickly dotted with chocolate-crimson spots and a gold band runs hrough the center of each petal. Blooms abont July zoth. While it is hardy, for best results some protection should be given the bulbs in the fall. Extra strong bulbs, imported directly from Japan for our customers. Each, 20 cents; dozen, \$I.85.

\section{ELEGANS LILIES}

The Flegans Lilies include several very hardy varieties. All have cupshaped flowers that are borne upright. Especially fine for massing. Elegans atrosanguineum. Deep blood-red flowers and dark, foliage. Blooms latter part of June. Each, 20 cents; dozen, $\$ 1.85$.

Elegans Batemani. Flowers orange-salmon. One of the largest of the Elegans varieties. Blooms July ist. Each, 20 cents; dozen, \$r.85.

Elegans incomparable. Deep red. Blooms about July Ist. Each, 20 cents; dozen, $\$ \mathbf{r} .85$

Elegans Wallacei. Flowers ricb vermilion-orange, spotted maroon. Blooms in the autumn. Fine. Each, 20 cents; dozen, $\$ 1.85$.

\section{SPECIOSUM LILIES}

The Speciosum Lilies are among the most desirable for all purposes. Entirely hardy and vigorous, the flowers are distinguished for grace, delicate colors and fragrance

Speciosum rubrum. White and rose, dark crimson spots. Blooms August 15 th. Each, 20 cents; dozen, $\$ \hat{x} \times 85$.

Speciosum album. White. Blooms August 15th. Each, 20 cents; dozen, $\$ x .85$.

Speciosum Melpomene. Crimson, spotted with deep blood-red; each petal distinctly bordered with white. Same habit as Speciosum rubrum.

dark and color of flower much deeper. Each, 20 cents; dozen, \$1.85.

\section{OTHER CHOICE LILIES}

Canadense. Our native Lily. Flowers nodding, delicate scarlet, yellow throat spotted black. Blooms July roth. Each, 15 cents : dozen, $\$ 1.25$.

Candidum. 'The common White Lily. Hardy, free bloomer, fragrant. Orders taken for August delivery. Cannot be planted at any other time. Each, is

Golden Cleam. A Charming Novelty. This beautiful new golden a yellow lily is a seedling of Tenuifolium and has and crowned with an ample cluster of graceful, delicate flowers of a golden yellow color. Each, 40 cents: balf dozen, \$2.no: dozen, \$3.50.

For a complete list of the Best Hardy Plants for the garden, you are referred to our Catalogue "Hardy Plants Old and New," which illustrates and describes Hardy Plants, Roses, Shrubs and Climbers. A copy will be mailed free on request. 


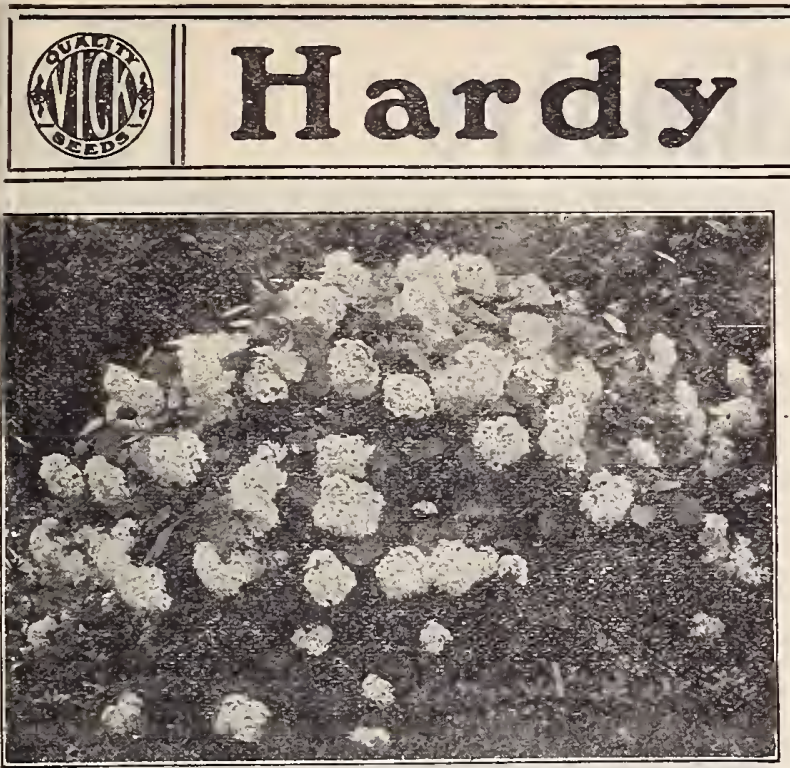

HYDRANGEA ARBORESCENS

\section{HYDRANGEA}

Arborescens grandiflora alba: This heautiful Hydrangea remains in hloom practically the whole summer. The large trusses of bloom resemble those of the tender Hydrangea and are made up of large, snow-white fluwers. It attains a height of five to six feet and about the same hreadth. The folıage is very attractive and the plant is gracefu' in form. Strong, one-year plants, each, 25 cents; three for 60 cents; dozen, $\$ 2.25$. Two-year plants, each, 50 cents ; dozen, $\$ 5 . \infty$.

Paniculata grandiffora. One of the finest hardy shruhs in cultivation. $1 \mathrm{inmense}$ flower trusses from nine to twelve inches in length, and nearly as broad. Color purest white, changing to deep pink. It blooms in July a ad remains beautiful until destroyed by frost. The plants we offer will all bloom the first season. First size, each, 50 cents; two for 80 cents; dozen, $\$ 4.50$. Second size, each, 25 cents; three for 60 cents; dozen, $\$ 2.25$.

\section{ALTHEA}

Rose of:Sharon. Beautiful erect-growing shrubs, of the easiest culture, hearing large showy flowers early in the fall. Very desirable because of flow ering when few other shrubs are in hloom. Double Red, Double White and Double Pink, each, 25 cents; dozen, $\$ 2.50$.

\section{BERBERIS}

Thunbergii. Japanese Barberry. Grows into a low, dense symmetrical form without pruning. The abundant small leaves turn to a bright crimson in autumn, and the hrilliant red berries remain fresh all winter. Beautiful as a single plant or for a low hedge. Each, 25 cents ; dozen, \$2.50.

\section{CALIFORNIA PRIVET}

The best known plant for hedges. A fast grower, Ene foliage, hardy ; may be trimmed to any form; thornless and nearly evergreen. Three-year plants, two and one-half to three feet high, $\$ 6.00$ per 100; $\$ 55$ per 1000 , ex press not prepaid. Two-year plants, fifteen inches high, $\$ 4.00$ per I00; $\$ 35$ per I000, express not prepaid.

\section{DEUTZIA}

We highly recommend the Deutzia for its hardiness, good habit, and great profusion of hloom. It is one of the most desirable hardy shrubs.

Crenata latifolia. New. La: ge panicles of eighteen to twenty single blossoms. The flowers are pure white with a center of golden yellow. Very at tractive. Each, 50 cents.

Crenata magnifica. New. A great acquisition. The pure white double flowers are over an inch in diameter. The plant is vigorous and the flowers are borne in large trusses. Each, 50 cents.

Lemoinei. Flowers single, pure white, and entirely covering the branches. Strong plants, each, 20 cents.

\section{FORSYTHIA}

Suspensa Fortunei, Golden Bells. One of the earliest spring-flowering shrubs, producing large, bright yellow flowers. Each, 25 cents.

\section{Shrubs}

\section{LILAC}

Purple. The old well known purple variety. Each, 25 cents : dozen, \$2.50. PURPLE FRINGE

Smoke Tree. A spreading shruh, completely covered in summer with large, feathery, purplish panicles, having the appearance of clouds of smoke. Each, 20 cents : dozen, \$2.00.

\section{SNOWBALL}

Viburnum piicatum. Japan Snowball. The pure white flowers are very lasting, and the beautiful folinge is nol attacked by insects. Of moderate growth. Lach, 30 cents : dozen, $\$ 3, \infty$.

Viburnum Opulus sterilis. The well-known Snowball. Produces large clusters of snow-white flowers in May. Each. 20 cents; dozen, $\$ 2.00$.

\section{SPIREA}

The Spireas are in the front rank among flowering shrubs for the lawn ar gardell. Beginning to bloom in May, many varieties produce flowers ard throughout the summer.

Each, 5 cents ; any two for 40 cents; dozen, $\$ 2.25$

Arguta, Flowers cleir white and freely produced. 'The best very early-flow-

eling white Spirea. A valuable hardy shrub, es pecially desirable for bedding
Anthony Waterer. A and borders. Grows from twelve to fifteen inches high, in a compact, bushy form. It is a perpetual bloomer, hearing large clusters of bright crimson flowers all through the season.

Billardi. Flowers rose-colored, in terminal spike-like panicles, uroduced nearly all simmer.

Bumalda. Half dwarf. Flowers deep rose,

Douglasi. Four to five teet high. Flowers rose-colored.

Van Houttei. A v:gorous plant that sends up numerous tall, slender shoots which curve gracefully, and the last of May or in June are literally covered with pure white flowers, making the bush a mass of bloom.

\section{SYRINGA}

Philadelphus grandiflorus. Tlowers pure white, fragrant. A very popula

shrub. Each, 25 cents; dozen, $\$ 2.50$.

\section{TAMARIX}

Hardy shrub, with very graceful and handsome feathery foliage. The plant flowers so freely that in the early summer it is one mass of pink bloom, completely hiding the foliage. Each, 25 cents; dozen, $\$ 2.50$.

\section{WEIGELA}

Handsome summer-flowering shrubs, with an ahundance of trumpet-shaped flowers, borne in clusters. E:ch, 25 cents; three for 60 cents; doz., \$2.25. Eva Rathke. Large purplish red flowers.

Nana variegata. Leaves variegated, green, yellow and pink. Flowers delicate rose and pink. A charming shrub.

Rosea. Rose colored flowers, borne in the greatest profusion.

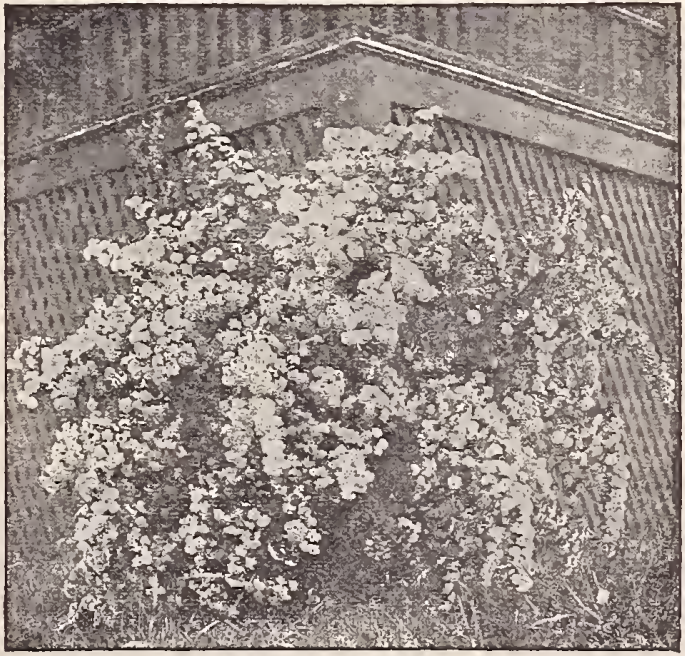

SPIREA VAN HUUTTEI 


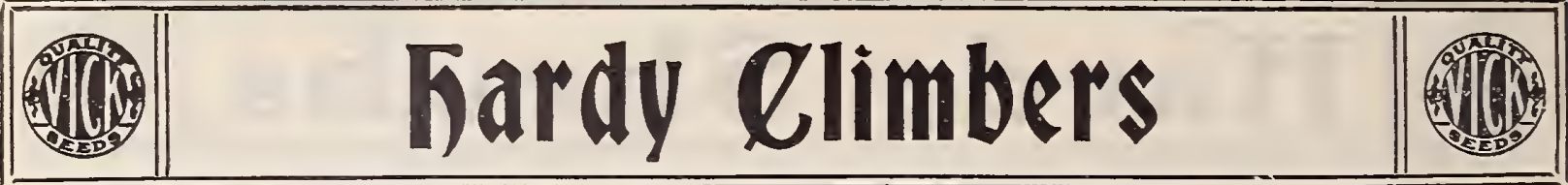

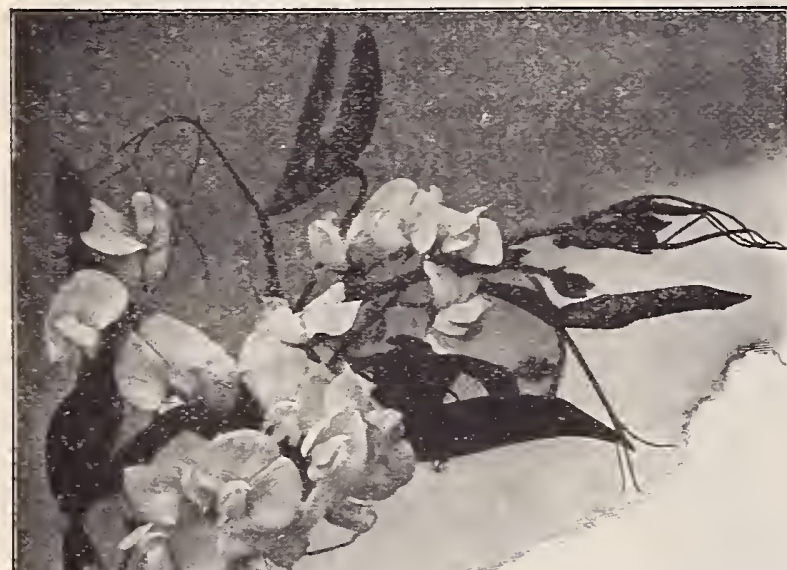

PERENNIAL PEA

Everlasting Pea. A very

desiraole perennial climber: and thoing the flowers are not fragrent like the Siveet Pea, they are very band. some, and will be found well worth growing. We offer two colors, pink and crimson,

AMPELOPSIS

Strong vines, 25 cents; two for 40 cents; dozen, \$2.00.

Quinquefolia. Virginia Creeper. Sometimes cailed American Iry and Woodbine, A rapid grower. Foliage crimson in autumn.

Each, 20 cents; dozen, \$.00.

\section{AKEBIA QUINATA}

A hardy, strong growing Japanese climbing plant, with curious purplish flowers, ormamental berries and handsome compound leaves, composed of five leaflets. An interesting plant. Each, 25 cents.

\section{CHINESE MATRIMONY VINE}

A vigorous and bardy climber. Flowers bright purple, succeeded by scarlet berries nearly one incb long. Excellent for trellises.

\section{Each. 25 cents; two for 40 cents; dozen, $\$ 2.25$}

\section{CINNAMON VINE}

A very rapid climber of incomparable beauty, with flowers of exquisite perfume. The growth is very rapid and the vines cover a large space in phort time is grown from a tuber is perfectly hardy and will live out of doors without protection. The vine dies to the ground each fall, and starts growth early in the spring.

Tubers, Each, 15 cents; two for 25 cents; dozen, $\$ 1.25$.

\section{DUTCHMAN'S PIPE}

Aristolochia Sipho. The Aristoluchia is a floral curiosity. It is a rapid growing hardy climber. attaining a heigbt uf thirty or more feet. It has flowers. Strong plants. Each, 50 cents; dozen, $\$ 5.00$.

\section{HONEYSUCKLE}

The different varieties of Honeysuckle are esteemed among the most desirable hardy' climbers. 'They grow with great freedom in any' good garden soil. Hall's Japan Honeysuckle is remarkable for the persistency of its leaves, the foliage usually remaining sreenlong after severe freezing

Heckrotti. New Sweet Scented Everblooming Honeysuckle. A magnificent variety, the finest yet produced. Remarkable for the large size and delicious fragrance of its flowers: color bright carmine red, witb yeliow and buft markines at the ends of the tubes. A healthy and vigorous grnwe and blooms contiuually the whole season. Each, 30 cents; dozen, $\$ 3.00$. Hall's. An evergreen variety from Japan. Flowers pure white, changing to
yellow. Very fragrant. Each, 25 cents; two for 40 cents; dozen, $\$ 2.00$.

\section{IVY}

English. The old popular variety. Hardy.

Each, 20 cents; two for 30 cents ; dozen, \$1.50.

Two-year-old plants, each, 40 cents; two for 60 cents.

\section{TRUMPET VINE}

Tecoma radicans, A fine, bardy. climhing large, foliage is also very beautiful. This plant on the lawn makes a pretty busb if the tops are cut back. Each, 20 cents ; dozen, SI.75.

\section{WISTARIA MAGNIFICA}

The Wistaria is a strong, rapid grower, desiralle fur trellises, porcbes, etc. When well establisbed it blooms profusely. The light purple fiowers ar very showy, and are produced in long racemes. A large plant in bloom is a beautiful sight. Perfectly bardy. Strong Roots. Each, 30 cents; doz., $\$ 3 . \infty$

\section{CLEMATIS}

The Clematis is the favorite climber of tbe world. It makes a rapid growth producing its sbowy flowers in great proiusion. In the fall give the plints a good top-dressing of well-rotted manure. The following spring spade in the manure, nixing well with the soil, and it will prove very beneficiai.

Jackmani, Flowers large, intense violet-purple; produced in great profusion blossoms from four to six inches in diameter. The most beautiful hardy climber in cultivation. Each, 40 cents.

Madame Edouard Andre, A valuable new variety ; distinct new color: fine bright crimson, witb no purplisb sbade about it. Large flowers, borne so profusely that it is called Crimson Jackmani. Each, 40 cents.

Paniculata. A remarkably beautiful climbing plant. Flowers pure white, star-sbaped, about one inch in diameter, borne very freely in large clusters: will last several days as cut flowers, retaining their fresbness and fragrance. The plant is a strong, quick grower. One of tbe most desirable and useful o climbing plants. Each, 25 cents; two for 40 cents: dozen, \$2.00. The Set of three Clematis for go cents.

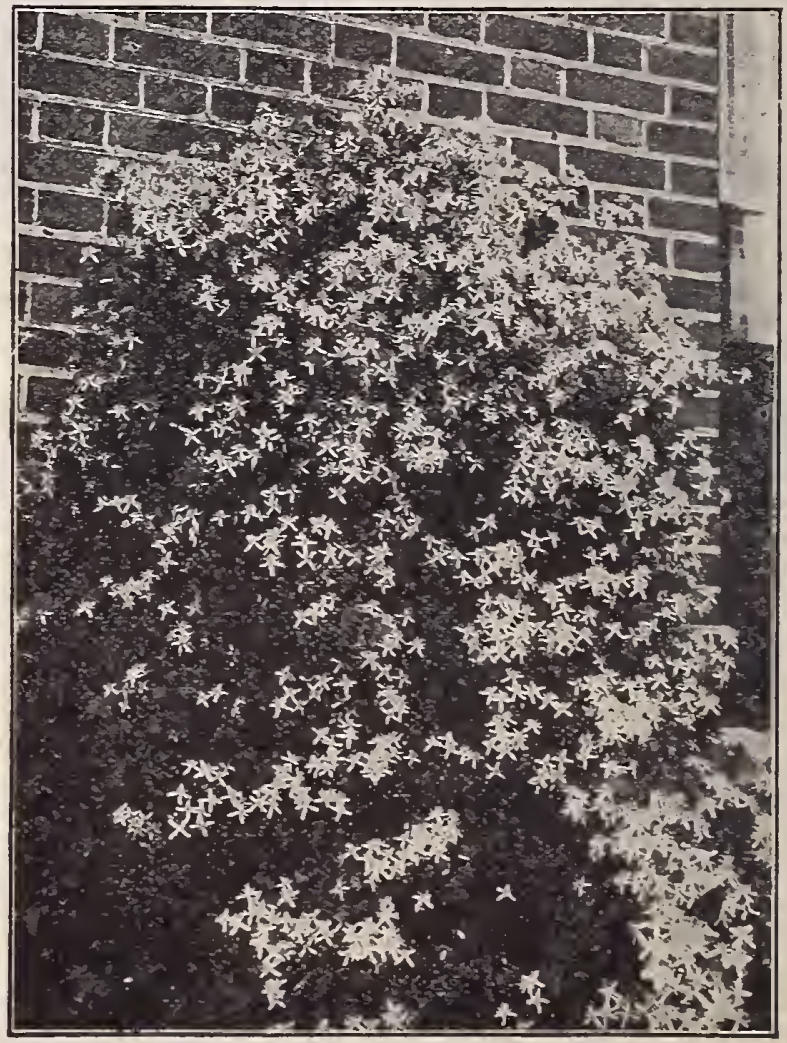

CLEMATIS PANICULATA 


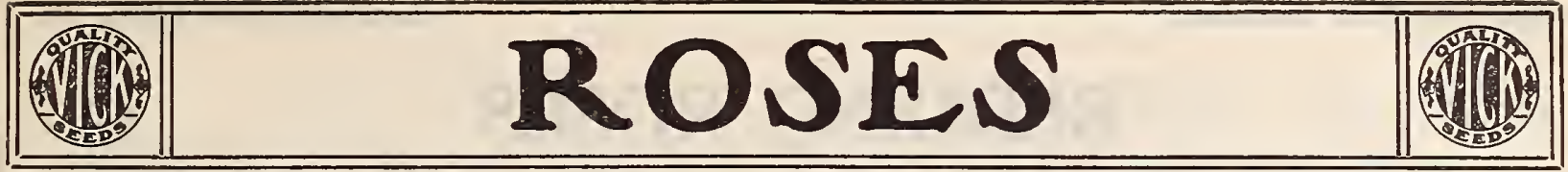

THE flowers of the Hybrid Perpetual class are generally large, double and very fragrant. Being perfectly hardy, these Roses may

1 be planted out in the open ground and left all winter without any protection, and will for years continue to yield an immense crop of flowers in June, and many of them will bloom freely throughout the season. If you wish to have flowers constantly in bloom, you must feed them well to bring them to perfection; they must have a very rich soil to do their best. Do not let them suffer for want of water during the growing season; this is a matter of great importance.

All strong two-year field grown, each, 35 cents; per dozen, $\$ 3.75$. Except where noted.

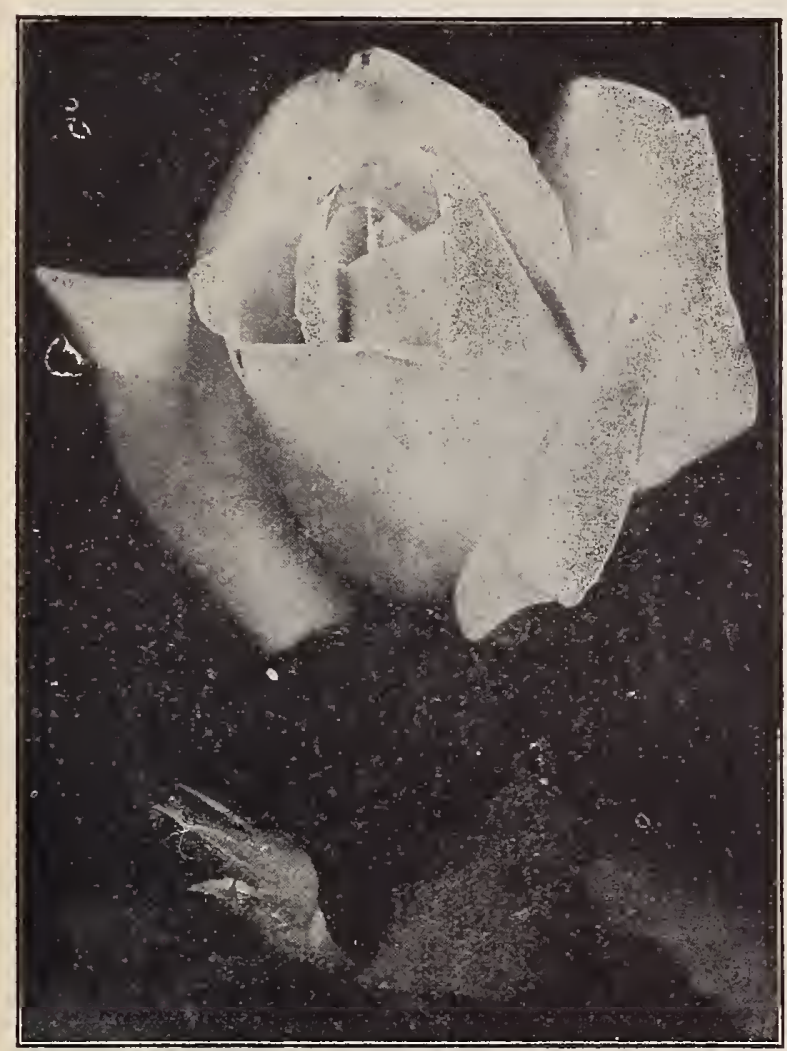

HYBRID PERPETUAL, FRAU KARL DRUSCHKI

\section{Caroline Marniesse}

\section{A Grand Everblooming Hardy Rose}

The flowers are creamy white, medium size, very double and sweetly tea-scented. There is not a week from late in May till the middle or latter part of October that large quantities of blossoms cannot be picked from these plants. Growth low and somewhat spreading, making it especially valuable for the borders of beds and for massing. Unequalled for cemetery planting. Strong two-year plants, each, 35 cents; dozen, $\$ 3.75$ Strong one-year plants, each, 25 cents; dozen, $\$ 2.50$

\section{Moss Roses}

The peculiarities of the Moss Roses are the delicate prickles which crowd their stems, and the beautiful inossy covering of their opening huds. They are strong, vigorous growers, and are perfectly hardy. each, $25 \mathrm{cents}$; doz.,\$2.50. Henri Martin. A magnificent Moss Rose. Extra large, and perfectly double. Color a deep rosy carmine, shaded a bright crimson.

Madame de la Rochlambert. Bright pink.

Princess Adelaide. Pale rose. Good in the bud and flower. Foliage dark. White Bath. Pure white. Best of the white Moss Roses.

\section{Hybrid Perpetual Roses}

American Beauty. One of the largest and most beautiful of double, and delighftully fragrant Rich rosy crimson color. Plant a strong grower and continuous bloomer. It will make a much stronger growth if not allowed to bloom the first summer. Pinch off tbe larger portion of the buds-betterall of them. This will not be necessary the second season, as the plant will tben be strong enough to make both growth and bloom. Extra strong plants, each, 50 cents; two for 80 cents; dozen, $\$ 3.75$.

Anne de Diesbach. Glory of Paris. Brilliant carmine: long pointed buds; large, finely-formed, compact flowers: very sweet; free bloomer. Valuable for forcing, and a superior garden sort.

Baron de Bonstetten. Splendid shade of dark red, changing to velvety maroon.

Clio. Flowers large, of fine globular form: flesh-color, shaded in center witb rosy pink. Vigorous grower and handsome foliage. Une of the finest Roses.

Frau Karl Druschki. A new hardy Rose and a grand variety. long; color a pure white. The plant is a very vigorous grower and produces flowers throughuut the season. Sometimes called the White American Beauty.

Francois Levet. Cberry-red; flowers of large size, well formed; very free blooner and of vigorous growth. An excellent Rose.

Gen. Jacqueminot. Rich crimson-scarlet, very bright and velvety. It produces beautiful buds that are much adnired, and in great demand.

Magna Charta. Beautiful bright pink, suffused with carmine. A general favorite.

Marchioness of Londonderry. A white, free-flowering $\mathrm{Hybrid}$ Perpetual. Flowers of great size, measuring five inches across, perfectly tormed and carried on long stems; color very white: petal of great substance, shellshaped and reflexed. Highly perfumed. Growth vigorous and foliage very handsome. One of tbe finest.

Margaret Dickson. Distinctly a garden Rose. A splendid white Hybrid Pe petual. combining the sterling qualities of entire hardiness, vigorous growth, and repeated blooming, with the fragrance, beauty of form, and waxy texture of the finest 'T'ea Roses. 'The flower is of magnificent form and very large. In colsr it is the most beautiful waxy-white, shining with almost the luster of a pearl.

Marshal P. Wilder. Cherry carmine, flowers large, semi-globular, full, well tormed, very fr. grant. Contintes to bloon long after most Hybrid Perpetuals are out of flower.

Mrs. John Laing. Delicate pink; large, fine form; very fragrant. Flowers continuously tbe entire se:tson in the open ground.

Paul Neyron. Probably the largest Rose in cultivation, and one of the best bloomers. Color a bright shining pink, clear and beautiful. The plant is an exceptionally strong grower, often making shoots four to five feet in one season, earb shoot bearing an immense flower. A rose we highly recommend.

Prince Camille de Rohan. Rich, dark, velvety crimson, shading to maroon; very double and sweet.

Ulrich Brunner. Brilliant cherry-red; fine form and finish. Plant vigorous and hardy. One of the best.

\section{Hardy Yellow Roses}

Strong, two-year plants, each, 35 cents: dozen, $\$ 3.75$

\section{Soleil d'Or}

This magnificent variety is perfectly hardy, robust and vigorons, making a growth of about three feet in height. Tlie buds are conical-shaped, of a lovely hue, the flower when expanded being, well incurved and about three and one-half inches in diameter. Superb in color, varying from gold and orangeyellow to reddish gold, shaded with nasturtium-red.

\section{Persian Yellow}

The flowers are nearly double and borne in immense clusters. The color is a deep golden yellow. The plants are a perfect mass of flowers in. June. 


\section{BEDDING ROSES}

\section{Everblooming Tea, Hybrid Tea and Dwarf Rambler Roses}

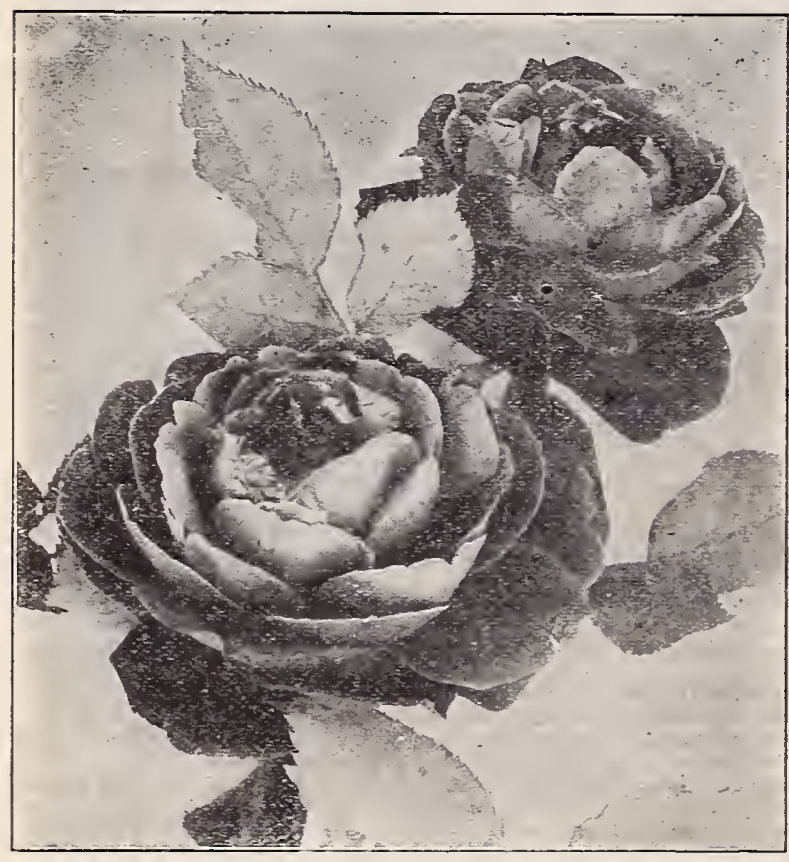

GRUSS AN TEPLITZ

\section{The Wonderful Set of Bedding Roses}

The best bedders. Perfectly hardy and always in bloom

Etoile de France. Velvety crimson, on stiff erect stems, cupped form. The best and sweelest hardy Hybrid 'Tea Rose of its color.

Gruss an Teplitz. Color a rich scarlet, shading to velvety crimson: very fragrant; a free, strong grower, and the most profuse bloomer known to us, being covered with flowers the whole season. The follage is extremely beautiful, all the younger groutb being of a bronzy plum-color.

Kaiserin Augusta Victoria. Pearly white, softly tinted with lemor in center; fragrant. A strung healthy grower, with bold beantiful foliage. Particularly hardy and one of the most beautiful Roses in cultivation.

Killarney. A grand new Hybrid Tea Rose, nerfectly hardy and a perpetual bloomer. The color is a bright sparkling pink; flowers very large and the buds long and pointed.

La France. Delicate silvery rose, changing to silvery pink. Very large, full, and of fine globular form. A constant bloomer. One of the sweelest and most useful of all Roses.

Pink Maman Cochet. The Queen of all Pink Garden Roses. The buds are lirge, full and firm. The color is a rich pink, changing to silvery rose. The flowers ire perfectly double, extra large and of splendid substance.

White Maman Cochet. Identical with its parent, Pink Maman Cocbet, except in color, wluch is snowy white, with sometimes a faint tinge of pale blish. It has the same freedom of bloom, forn of buds and flowers as Pink Maman Cochet.

The above seven varieties, each, 35 cents; dozen, $\$ 3.75$ : the set of seven, $\$ 2.75$. These pricts are for strong, two year field-growil plants, that will produce a full crop of flowers the first year.

\section{Other Bedding Varieties}

Bessie Brown. A strong vigorons-growing $\mathrm{H}_{\mathrm{y}}$ brid Tea Rose, flowering in the greatest profusion the entire summer. The culor is a creamy white. faintly, flushed with pink. Each. 20 cents; dozen, \$2.00.

Mrs. Wm. H. Taft. This is one of the most profuse bloommg, brightest colored, sweetest scented Tea Roses ever grown. The color is a rich pinh. A good bedding variety. Each, 25 cents; dozen, $\$ 2.50$.

\section{Monthly Everblooming Roses}

Dozens of flowers can be cut from a bed of Monthly Roses every day, from June to November. To be successful with Monthly Everblooming Roses you must have rich soil for them to grow in. Old, well-rotted manure is the best ferilizer; a bright, sunny location and in hot, dry weather, a good tborough soaking with water eacb day, and you will have plenty of deligbtfully fragrant flowers.

Fine strong plants, each, I5 cents; dozen, \$1.50.

Bon Silene. Rich crimson shade, beautifully tinged with salmon.

Clothilde Soupert. Flowers of medium size, double, and beauvfully formed; oval at first but flattening as they" expand. I be color is pearly white at the outer edge, shading to a center of rosy pink, sometimes varying to nearly pure w bite. Very fragrant. Constant bloomer.

Crimson Hermosa. Queen's Scarlet. Flowers large; of a fiery scarlet. Francisca Kruger. Flowers large, coppery jellow shaded with peach. Gruss an Tepiitz. See preceding column.

La Princess Vera. Rich ivory-white, shaded with coppery yellow, Niarechal Neil. Yellow, tea-scented.

Marie Van Houtte. Creany white, outlined with bright rose. Papa Gontier. Brilliant carmine, changing to pale rose.

Perle des Jardins. Ricb shade nf yellow; very perfect in form.

Pink Hermosa. One of the best known of all Roses. Perfectly hardy. Pink Maman Cochet. See preceding column.

Princess de Sagan. The richest crimson Rose in our collection.

White Maman Cochet/ See preceding column.

My Maryland A new Hybrid Tea Rose. T be flowers are large full and double and very perfectly formed. The color is a most distinct and beautiful rose pink. Free branching and free growing. Each, 25 cents; dozen, $\$ 2.50$.

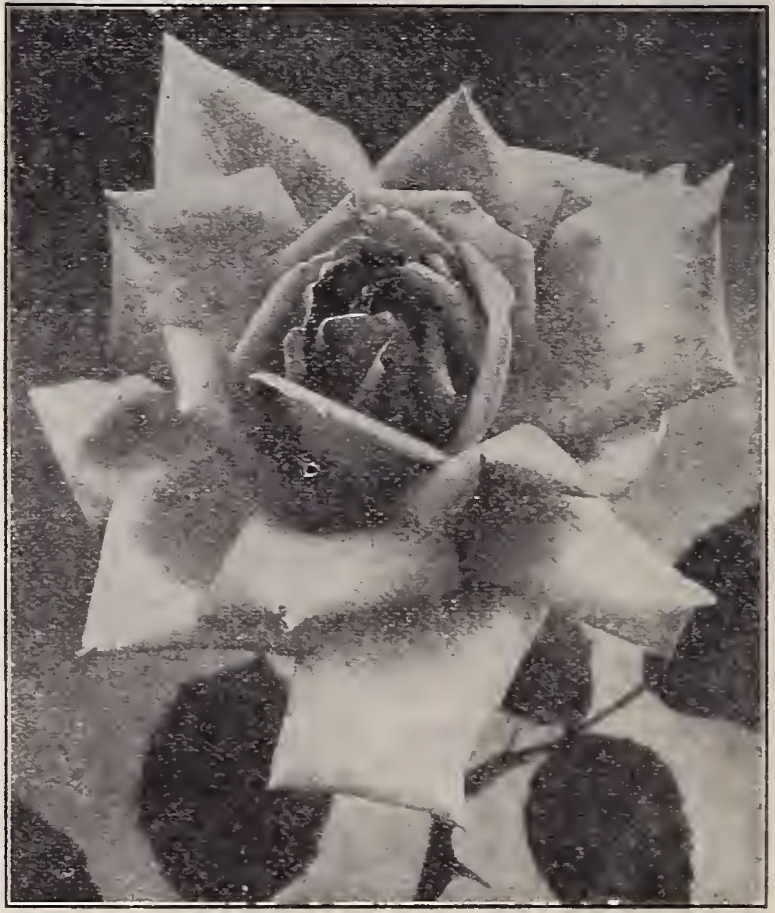

KAISERIN AUGUSTA VICTURIA 


\section{SUNBURST}

A magnificent, new, everblooming yellow Tea rose, surpassing any heretofore offered. The flowers are of the largest size, with long, pointed buds. The color effect is extremely brilliant, showing intense shades of orange-copper, golden-orange and golden-yellow. The plants have extraordinary vigor, producing healthy foliage and long stemmed flowers. It does splendidly out of doors.

Each, 25 cents; dozen, $\$ 2.50$.

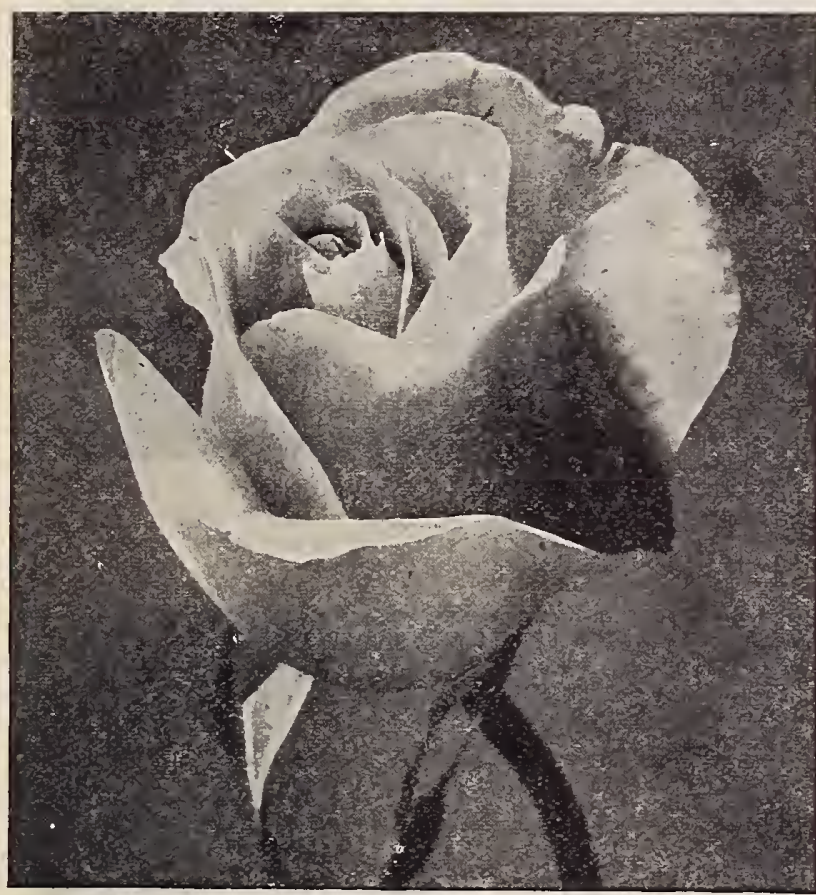

KILLARNEY ROSE (Page 86)

\section{Dwarf Rambler Roses}

\section{Crimson Baby Rambler}

A Dwarf Rose that blooms from early June to December

This beautifut Rose produces clusters of flowers as large as the old Crimson Rambler. The color is a charming brilliant red, and it blooms with great profusion. As a pot Rose it has no equal, as it is a continuous bloomer.

Strong young pot plants. Each, 15 cents ; dozen, \$1.50.

Field grown plants. Each, 35 cents ; dozen, $\$ 3.75$.

\section{Amy Muller, or Pink Baby Rambler}

This dwarf variety is a fitting companion to the well-known Crimson Baby Rambler. The plants branch freely and attain a height of about eiglteen inches. The showy brilliant rose-colored flowers are produced in the greatest profusion from June until fall. Each individual flower measures about two inches in diameter. The petals are sometimes twisted which gives the flower a very unique appearance. Each, 25 cents; dozen, \$2.50.

\section{White Baby Rambler}

This Rose is a little beauty, with pure white double flowers. A constant bloomer and as grand a bedder as the Crimson Baby Rambler.

$$
\text { Each, } 20 \text { cents ; dozen, } \$ 200 .
$$

\section{Baby Dorothy}

Clear pink. A dwarf form of the climbing rose, Dorothy Perkins, which it resembles in foliage and color of flower. The flowers are produced in large clusters.

\footnotetext{
Each, 20 cents; dozen, \$2.00.
}

\section{CLIMBING ROSES}

\section{Dorothy Perkins}

A hybrid of Rosa Wichuriana and Mme. Gabriel Luizet. In its foliage, growtl and habit of bloomung, it is similar to Cirimson kambler, but the flowers a se inore double and of a beautiful shell-pink color and hold a long time without fading. The flowers are very sweelly scented, a characteristic not possessed by most other Ramblers. Strong two-year field grown plants. Each, 35 cents ; dozen, $\$ 3.75$.

\section{Helene}

A seedling from Crimson Rambler and a climbing rose of rare beauty. It is of very rubust growth, throwing up canes ten to fifteen feet high in a single season. The color is a pure soft violet-rose, almost blush; base of petals yellowish. The buds are carmine, mossed and borne in clusters of from twenty-five to fifty. Perfectly hardy. Strong two-year field grown plants. Each, 35 cents; dozen, $\$ 3.75$.

\section{Tausendschoen}

The flowers are borne in large clusters from June to August. They are a beautiful soft rose-color, changing to rose-carmine. The plant is a strong grower, perfectly hardy and nearly thornless. The shining dark green foliage is never attacked by disease or insects. Two year plants. Each, 35 cents; dozen, $\$ 5.75$

\section{Climbing Ramblers}

The Ramblers are perfectly hardy and wonderfully strong growers. The flowers are well formed and, though small, are produced in so great profusion as to present an immense mass of bloom. Many of our customers report that single plants when in bloom showed thousands of flowers.

Crimson Rambler. Two-year plants. Each, 35 cents; dozen, $\$ 3.75$. White Rambler. Two-year plants. Each, 35 cents; dozen, \$3.75. Yellow Rambler. Two-year plants. Each, 35 cents; dozen, \$3.75. Pink Rambler. Two- year plants. Each, 35 cents ; dozen, $\$ 3.75$. Set of the above Four Ramblers \$1.25.

\section{Philadelphia Rambler}

This Rose is a cross between the popular Crimson Rambler and the fiery crimson Hybrid Perpetual, Victor Hugo, and is identical with the Crimson Rambler except that the color is a brighter crimson, and never fades. It is a valuable acquisition to the list of climbing Roses. Strong two-year plants. Each, 35 cents; dozen, \$3.75.

\section{Lady Gay}

A vigorous grower and perfectly hardy. Superior to Crimson Rambler. which it resembles in habit and general effect. The flowers are of good size and delicately perfumed. In color they are a delicate cherry pink, fading to a soft white. The color effect is most charming. Strong two-year plants. Each, 25 cents ; dozen, $\$ 2.50$.

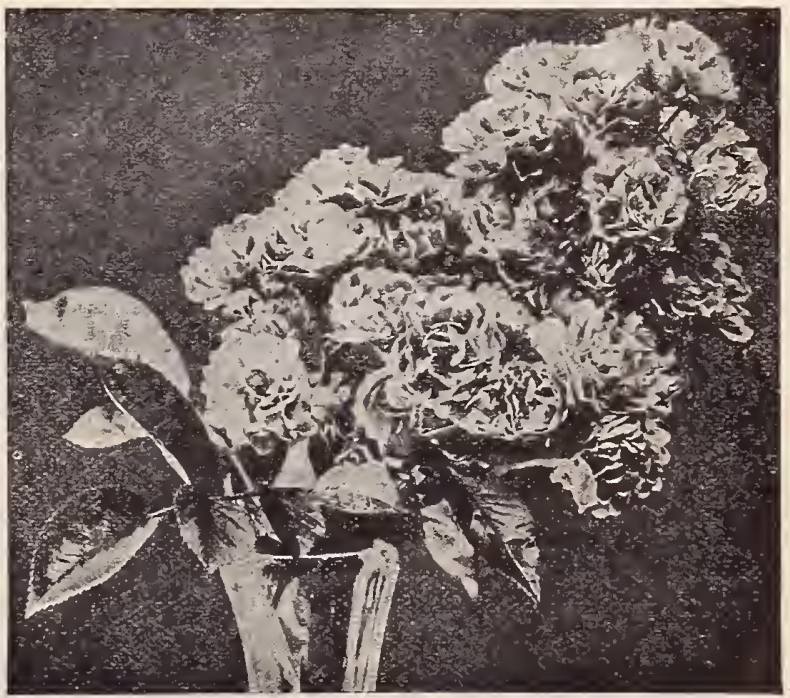

CRIMSON RAMBLER 


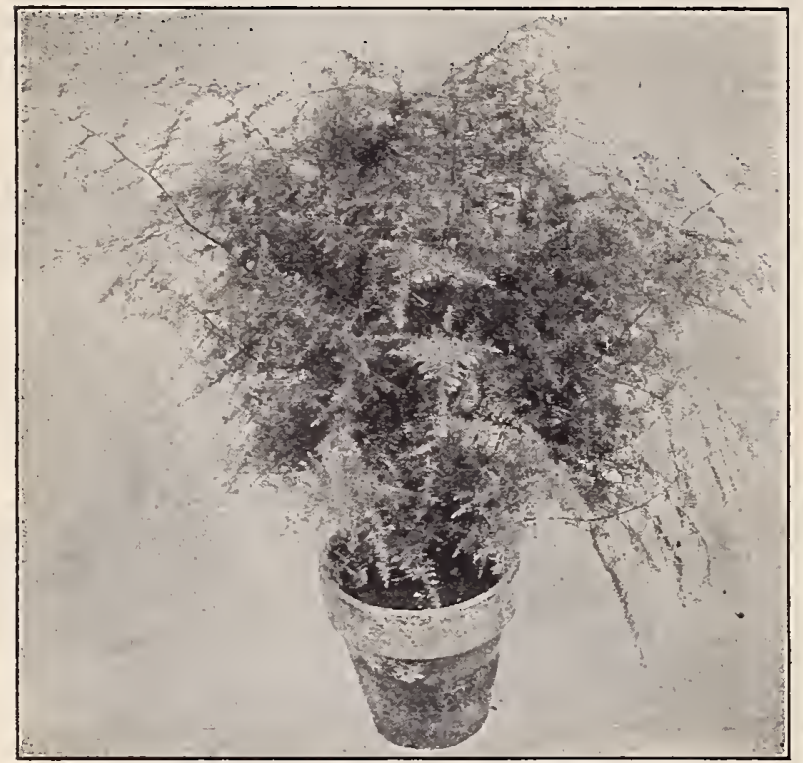

ASPARAGUS PLUMOSUS NANUS

\section{ASPARAGUS}

Each, 20 cents: two for 30 cents.

Sprengeri. One of the most rapid-growing plants that we know, making great masses of fine feathery foliage in a very short time. The stems grow several feet in length, and are valuahle for use in cut-flower work. Fine fos hanging haskets or large pots. As a bouse plant it has no superior, as it withstands the indoor temperature well.

Plumosus nanus, or Lace Fern. Beautiful on account of it: light feathery growtb, which very much resembles lace. The graceful dark green foliage surpasses the Maiden Hair Fern in delicacy of texture. Splendid as a pot plant and for decorative purposes.

\section{ABUTILON, Flowering Maple}

Hard-wooded greenhouse shrubs, blooming almost the entire year; well adapted for house culture. Flowers hell-shaped and drooping.

\section{Each, 15 cents ; dozen, $\$ 1.50$}

Eclipse. A trailing vareety, leaves beautifully marked deep green and yellow: the flowers are hright yellow, with crimson tbroat.

Golden Fleece. Fine. Pure yellow.

Snow Storm. Pure white.

Savitzii. The leaves are green with a heavy white border.

Souvenir de Bonn. Leaves deep green with white borders.

\section{ACUBA JAPONICA, Gold Dust Tree}

Very useful for decorative purposes and as a pot plant for the house, as it stands the atmosphere of a divelling house better than most plants. Leaves are dark green, spotted with golden yellow.

Each, 20 cents ; three for 50 cents.

\section{AGERATUM}

Each, I5 cents; dozen, $\$ 1.50$

Princess Pauline. Dwarf growth. Flower a light sky hlue.

Stella Guerney. The deepest hlue; exceptionally free-flowering.

\section{ANTHERICUM}

Each, 20 cents; dozen, \$2.0.

Vittatum variegatum. An elegant house plant, with dark green leaves bordered with pure white. Long spikes of star-shaped flowers. Fine for hanging baskets.

Picturatum. Center of tbe leaf white, bordered with green.

\section{CARNATIONS}

The delicately rich and grateful odor, in connection with the heautiful colors and perfect outline of the Carnation, secures for it a prominent place in all collections of plants, either for the house or garden. It is one of the sweetest of flowers and yields an ahundance of hloom all summer. The plants may he potted in Septemher, watered and shaded a few day's, and they will hloom all winter, in a hright sunny window. ()ur list emhraces a large assortment of colors, and the hest of the standard varieties.

Each, I 5 cents; three for 35 cents; seven for 75 cents. The set of thirteen for $\$ I .25$.

Alma Ward. One of the largest Carnations grown. Color pure white. Beacon. Beautiful shade of scarlet. Flowers very large. Stems long. Boston Market. Pure white. A marvel for early and cuntinuous hlooming.

Enchantress. Delicate shade of shell-pink, deepening towards the center; very large flower.

Harlowarden. Large flower of bright crimson, with scarlet shadings.

Lady Bountiful. Pure glistening white.

Mrs. Thomas W. Lawson. Immense size-from three to four inches in diameter-long, strong stems. Bright cerise-piuk, lighting up heautifully under artificial light

Red Jacket. A strong, rohust grower; culor brilliant scarlet.

Rose Pink Enchantress. Color rose pink; large flower.

Variegated Lawson. White striped with cerise pink.

White Enchantress. Pure white.

White Perfection. Very large pure white flower.

Winsor. Silvery pink. Une of the best carnations.

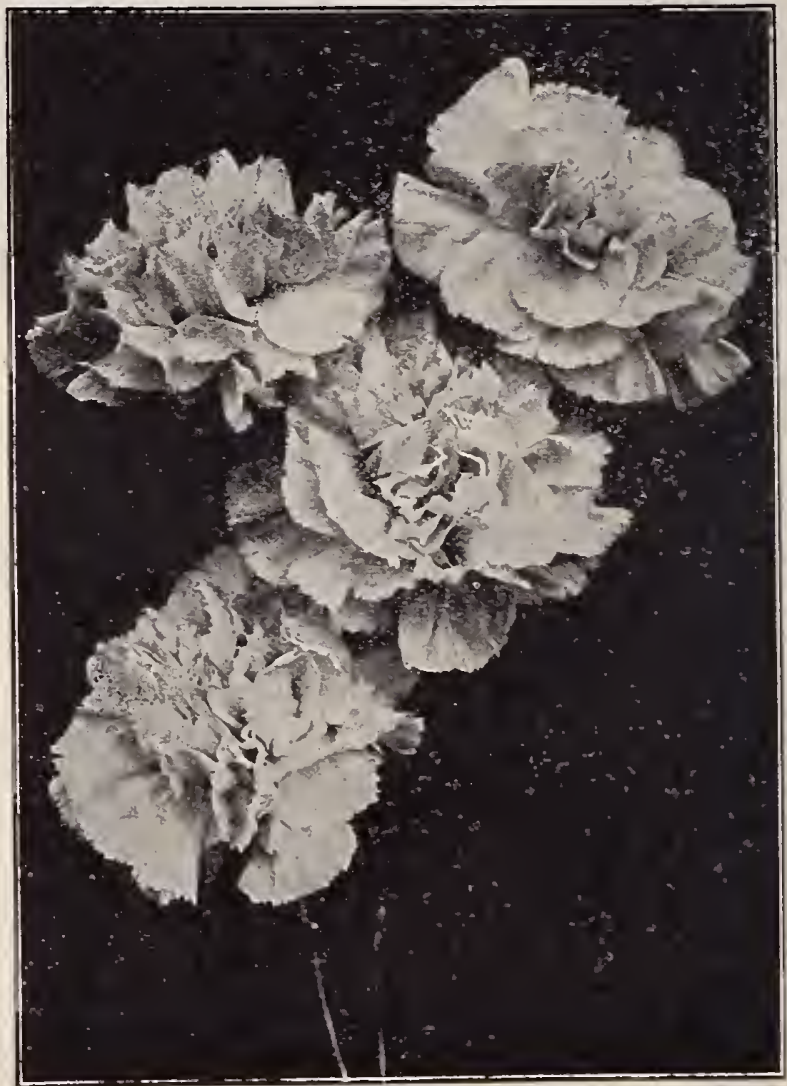

CARNATION, ROSE-PINK ENCHANTRESS 


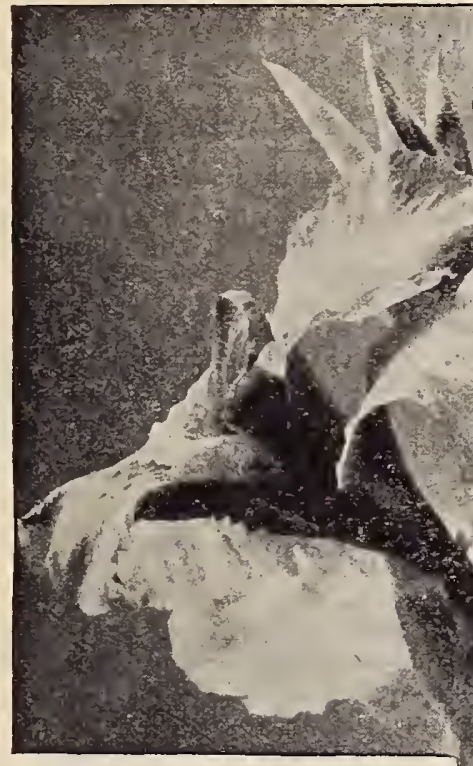

For a brilliant show all summer there is no plant excelling the Canna; it even surpasses the Geranium in its gorgeous display of brilliant colors, blooming continuously from the time of planting until cut down by frost.

\section{The Best of the Stand- ard Varieties}

Each, 15 cents; dozen, \$1.50.

Alphonse Bouvier. Open brilliant crimson, but change to a beautiful deep crimson as they more fully expand. Six feet high.

Alsace. Pale sulphur changing to creamy white. A valuable variety. Four and one-lialf feet high.

Beaute Poitevine. Bright crimson, with erect flower-spikes. Three and one-half feet high.

Brandywine. Brilliant red; folıage bronze. Four feet high.

Charles Henderson. Brilliant crimson flowers. Four feet high.

Cinnabar. Cinnabar red, distinctly marked with golden yellow. Four and one-half feet high.

David Harum. Bright deep satiny vermilion. Foliage bronze. Three and one half feet high.

Egandale. Soft currant-red flowers. Foliage bronze. "Four feet high.

Evolution. The flowers are golden yellow, which shades in through various tints of canary, lemon, and sulphur to a center of blush pink. Foliage bronze.

Fairfield. Rich dark crimson flowers; foliage green.

Florence Vaughan. Flowers of the most brilliant golden-yellow, dotted with brightest scarlet. Four and one-half feet high.

Jean Tissot. Brilliant vermilion, with bright orange markings. Foliage green. Five feet high.

J. D. Cabos. Height four feet. Color of flower light orange. Foliage bron e.

Mlle, Berat. The nearest approach to a pink in a first-class bedder. Four feet high.

Madame Crozy. Flowers crimson-scarlet and gold-bordered, Tinree and onehalf feet high.

Pennsylvania. The flowers are pure deep scarlet, of immense size. Six feet high.

President Meyer. The flowers are a rich cherry-carmine; foliage bronze. Four feet high. :-

President Faivre. Flowers amaranth-red; foliage bronze. A strong, erect grower, especially adapted to massing and as center of beds. Six feet high.
Queen Charlotte. The center of the petal is a brilliant crinson-scarlet, shaded with crinson and bordered with a wide belt of gold. Three feet high.

Robusta. A very fine, tall-growing, darkleaved variety; eight to ten feet.

Rubin. Ruby carmine. Foliage bronze. Secretaire Chabanne. A distinct and pleasing sliade of almond. Three feet high.

Semaphore. Novel color. The flowers are of a pure orange. Foliage bronze.

Souvenir d'Antoine Crozy. Crimson scarlet, broad yellow border. Four feet high.

\section{Orchid-Flowered}

\section{Cannas}

Each, 15 cents ; set of five for 60 cents Alemannia. Gigantic yellow flowers beautifully mottled with orange-scarlet. Four and one half feet high.

Burbank. rich canary-yellow flowers, spreading seven inches; rich green leaves; four and one-half feet high.

Italia. Immense flower. Center brilliant red, petals widely bordered with clear yellow. Six feet high.

King Humbert. Massive foliage ot finest bronze, with dark midrib. Its flowers measure six inches in diameter and are produced in great trusses. Brilliant orange scarlet, with bright red markings. Height about four feet.

Parthenope. Flowers are extra large and of good substance. Color dark orange, shaded with yellow: showy and distinct : four feet.

\section{Canna Beds}

Plant Cannas about 18 inches apart each way; the tal. warieties for the center of bed and the shorter ones ror the border. For a round bed, 7 feet in diameter, it will take 19 plants.

For a 7-foot bed we will send postpaid ig plants in three different varieties for $\$ \mathbf{2 . 2 5}$

\section{Flowering Begonias}

This class of beautiful plants is deservedty popular. The beauty of foliage combined with graceful flowers and free-blooming qualities, makes the plants lighly desirable. As pot plants for winter decoration they have few equals. Each, I5 cents; per dozeu, \$1.50.

Alba picta. Leaves narrow, sputted with white: flowers white; Argentea Guttata. Leaf bronze with silver markings. Flowers white. Foliosa A minature foltage variety, Flowers Dink, erect grower. McBethii. Flowers pure white f foliage finely cut.

Sandersoni. A bushy growing variety, with glossy, deep green leaves Sandersoni. A bushy growing variety, with glossy, deep
flowers in clusters of drooping scarlet; heart-shaped buds.

Zebrina. Foliage dark green with whitish veins, flowers light pink

\section{BEGONIA SEMPERFLORENS Wax Begonias}

This class may be truly called perpetual flowering Begonias as they bloom continuously. "lhey are alway's in bloom, and are very fine either for house plants or bedding. Three colors, pink, white and scarlet.

Each, 15 cents; three for 35 cents; dozen, \$1.25.

\section{REX BEGONIAS}

The Rex varieties of Begonia are very effective as pot plants. Care should be taken to keep the foliage free from dust. Occasionally the plants inay be showered, but should not be exposed to the sun until the leaves are perfectly ory. Each. 20 cents; dozen, 2.00.

Countess Louise Erdody. The wonderful cork-screw Begonia Grandis. Bronze,

Modesty. Leaves silvery white, edged with green

Pres. Carnot. Silvery white.

Surprise. Leaf deep bronze and silvery rose.

The Mystery. Foliage red and green, with silvery outer edge. Center or corkscrew shape.

Van der Hyde. Mottled green and white. 


\section{CHRYSANTHEMUMS}

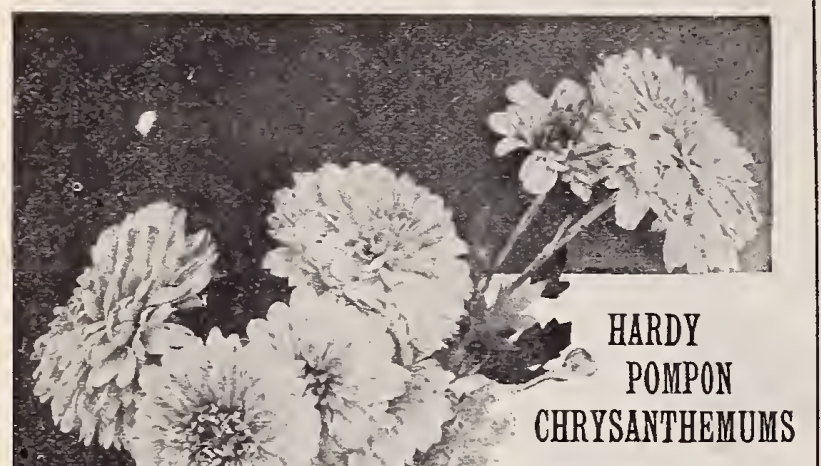

These are the very best of all Chrysanthemums tor planting out of doors, and they are growing in popularity each year. They are perfectly hardy, and the flowers which are not injured by the early frosts, give a fine show of bloom in late Antumn. The Single Chrysanthemums are also very desirable for growing 2s pot plants, being easily grown, I w a r f compact plants, and free bloomers. While the flowers of the Hardy Chrysanthemums do not attain the great size of the Large-Fowering varieties, the sprays of bloom are extremely graceful and beautiful and are very valuable as cut flowers. They may frequently be seen in the gardens about Rochester in full bloom as late as the middle of November.

\section{Each, I5 cents;} dozen, \$1.25; eighteen for $\$ 1.75$.

PONPUN CHRYSANTHEMUM

\section{Single Pompons}

Grace Darling. White edged with pink.

Katie Covell. Maroon.

Ladysmith. Pink, early.

\section{Double}

Allentown. Bronze yellow,

Alma. Beautiful pink.

Anna Mary. Creamy white, tipped pink.

Astarte. Bright golden amher.

Baby. Golden yellow.

Baby Margaret. Pure white; a

Bohemia. Pure yellow

Crimson Ball. A beautiful deep crimson.

Drin Drin. Smallest; pure yellow Edna. White, with pink shadings and yellow center; good size and nice form.

Elva. Pure white, early.

Gold Standard. Golden yellow.

\section{Large-Flowering Chrysanthemums}

\author{
Each, 15 cents; dozen, \$1.25; eighteen for \$1.75.
}

The glorious blooms of the Large-Flowering Chrysanthemums are easily the largest and most showy flowers of late autumn and early winter. In a warm fall the Large-Flowering ('hrysanthemums bloom well in October and November in the open ground. But a good way is to cultivate the plants in the garden, with plenty of room in good, rich soil, until the first of September, when they may be safely transferred to pots. Give a thorough watering and set in a shady place for a few days, after which they may be exposed to the full light in a cool room.

Alice Bryon. A magnificent snow-white variety.

Cheltoni. Golden yellow.

Christmas Cheer. Beautiful pink. Early. Flower incurved.

Comoleta. Bright yellow. Fine for pot culıure.

Cullingfordii. Rich crimson scarlet.

Golden Glow. The earliest of all. Fine golden yellow with velvety finish. Ivory. Dwarf. Free flowering, snow white, incurved, very large, perfect form Leon Truelle. Large flower of purest white

Major Bonnaffon. Soft yellow, incurved ty pe; flowers large and full.

Major Weaver. Large. Fine shade of pink.

Maud Dean. Extra large flowers, petals hroad, incurved; color light rose Mrs. William Duckham. Beautiful golden yellow.

Mrs. Jerome Jones. Waxy white; good stem and perfect foliage.

Naceur-Bey. Vellow, with distinct stripes of red in each petal.

Nellie Pocket. Creamy white.

Pacific Supreme. A beautiful shade of pink. Very early.

Pink Ivory. Beautiful shell-pink. A sport from White Ivory.

Pink Jones. The color is beautiful; each petal is white overlaid with purplish crimson, giving the whole flower the appearance of being pink in color.

Red Duckham. Very large flower. Color purplish crimson.

White Coombes. Pure white of largest size

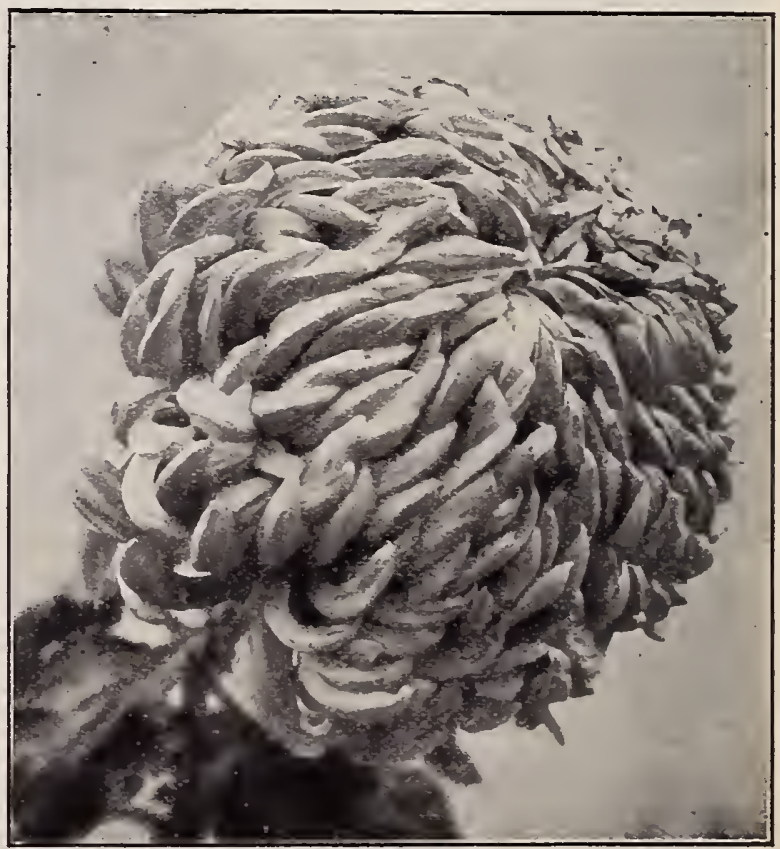

CHRYSANTHEMUM, MAJOR BONNAFFON 


\section{CALCEOLARIA}

Creole Queen. Flowers brown maroon. Very fine for pot plant and bedding. Easy to grow. Each, 15 cents; three for 30 cents.

\section{CAREX}

Japonica variegata. Japanese grass. Very useful and ornamental for the house, thriving well in a living room.

Each, 15 cents; two for 25 cents.

\section{COLEUS}

Each, I5 cents; any three for 35 cents; dozen, $\$ 1.25$.

Set of seven for 75 cents.

Crimson Velvet. Leaves rich crimson.

Duneira. Soft seal-brown, bordered pink. An exceptionally showy variety Firebrand. Maroon, flamed and shaded with brilliant fiery red.

John Good. Yellow and green, fine bedder.

Snowcloud. Yellow and green. Changing to white in the summer months. Sensation. Velvety black maroon, with lance-shaped center of pure magenta. Very brilliant.

Verschaffelti. Rich, velvety crimson. The best of all for bedding.

\section{DRACAENA}

Indivisa. Used extensively as a center plant for vases, baskets,etc. The numerous grass-like leaves are very long and rigid, contrasting nicely with other plants. Easily grown. Each, 15 cenţs; dozen, $\$ 1.50$.

\section{FEVERFEW}

Little Gem. Very dwarf; attains a height of from 8 to ro inches; flowers of fine form, and pure white. Each, 15 cents ; dozen, \$1.50.

\section{FRAGRANT OLIVE}

Olea fragrans. Rare and very choice house plant resembling the Orange in growth Thick, glosisy green leaves and deliciously fragrant flowers. Thrives best in a moderately cool room. Each, 25 cents.

\section{GREVILLEA, Silk Oak}

Grevillea robusta. A beautiful plant for decorative purposes; of quick growth and very easy culture. The leaves are very light bronze color, the tips being covered with a soft down resembling raw silk, from which it derives the name of " Silk Oak." For the house it is unsurpassed.

Each, 20 cents ; two for 35 cents.

\section{HELIOTROPE}

Prized for its fragrance. It is a favorite with everyone. Heliotropes require a sunny location, as they do not do well when grown in the shade. Very desirable for house culture, a single plant filling a whole room with perfume.

Lady Cook. Dark violet. Madame de Blonay. Pure white. Each, 15 cents; three for 35 cents; dozen, $\$ 1.25$.

\section{HYDRANGEA}

Otaksa. The immense heads of pale pink flowers, make the Hydrangea extremely effective as a decorative plant. North of Philadelphia grown as a pot plant. Give partial shade and plenty of water, Put in tbe cellar in the fall. Each 15 cents.

\section{LANTANAS}

Are in bloom constantly, and are very fine for bedding, baskets, or box plants. Each, 15 cents ; two for 25 cents ; dozen, $\$ 1.25$.

Amiel. Bright shade of orange-red, with golden center.

Jacques Minot. Yellow, changing to orange red.

Marcella. Lilac rose, changing to yel!ow.

New Weeping. Rose pink, habit drooping.

Snow Queen. Large white flowers.

Snowball. White, yellow center.

\section{LEMON}

Ponderosa. Large-fruited true Lemon, Flowers as fragrant as the Orange blossom and large fruit of good quality. Bears flowers and fruit at the same

time. Vigorous grower and makes a splendid house plant.

Thrifty young plants, each, 25 cents ; two for 40 cents.

\section{LEMON VERBENA}

Foliage delightfully fragrant. Easily grown. Each, I5 cents; dozen, \$I.50.

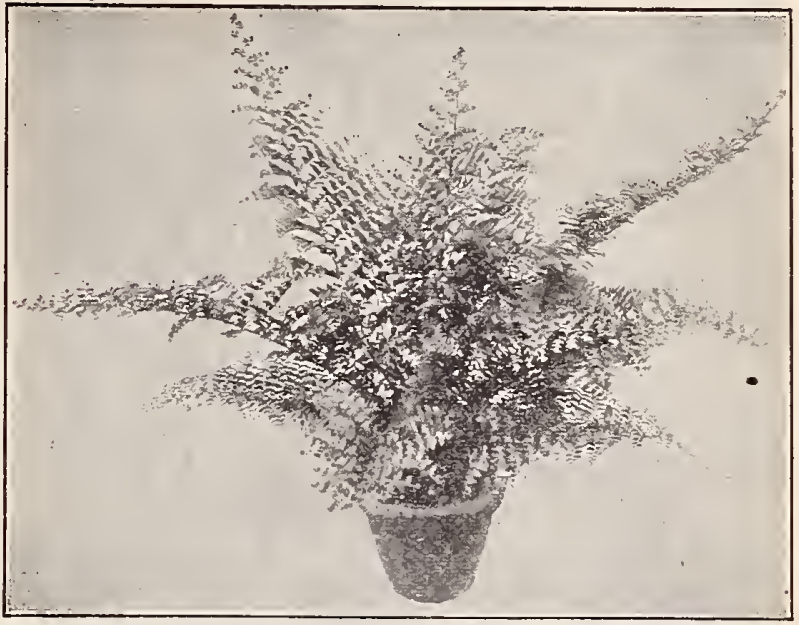

WHITMANI FERN

\section{FERNS}

Ferns cannot be dispensed $w$ th in elaborate decorations for the parlor. Those offered below are the hardiest and best for house use. They grow rapidly and many varieties soon double their original size.

The six varieties first named below are especially adapted to use in fern dishes. The six are suff cient for a dish eight inches in diameter.

$$
\text { Each, I5 cents; the set of six, } 75 \text { cents }
$$

Adiantum cuneatum. The popular Maiden Hair Fern.

Aspidium Tsussimense. A pretty species with dark green foliage.

Cyrtomium Falcatum. The "Holly Fern." Large, dark green glossy leaves.

Pteris Cretica albo-lineata. A pretty and useful variegated variety; leaves green and white.

Pteris Wimsetti. Fine for fern pans and house culture; finely crested. Pteris Wilsoni. Leaves round and crested. Splendid for house culture.

\section{Varieties of the Boston Fern}

The various kinds of the Boston Fern are all strong growing, beautiful plants, and well adapted to house culture.

Each, =0 cents; four for 75 cents; dozen, \$2.00.

Boston Fern - One of the most satisfactory of decorative plants for house culture. The handsome green fronds attain a length of four to five feet, and droop so gracefully over on every side that it is often called the Fountain Plant. It always has a fresh, healthy appearance, and is very attractive.

Scotti-Dwarf Boston Fern - A very dwarf and compact form of the Boston Fern. The fronds are short and narrow, of a graceful, recurving form. Plants of small size make nice specimens in a short time.

Scholzeli-Plumed Scotti Fern - In this fern, a sport from Scotti we have all the desirable features of the parent, with plumy fronds similar to the Ostrich Plume Fern. Its leaves are held erect with a graceful arch, forming a plumy globe.

Barrowsi- Ostrich Plume Fern.-Dark rich green. The long, graceful fronds are beautifully ruffled.

Roosevelt - The divisions of the wide drooping fronds are beautifully undulated and the fronds are more gracefil than those of the Boston Fern. Strong rapid grower. A new variety and one of the finest.

Whitmani-The plumy appearance of its foliage makes the Whitmani unquestionably the most striking among all the varieties of the Boston Fern. The plant is quite dwarf in growth; and the leaves very wide ; a grand fern, 


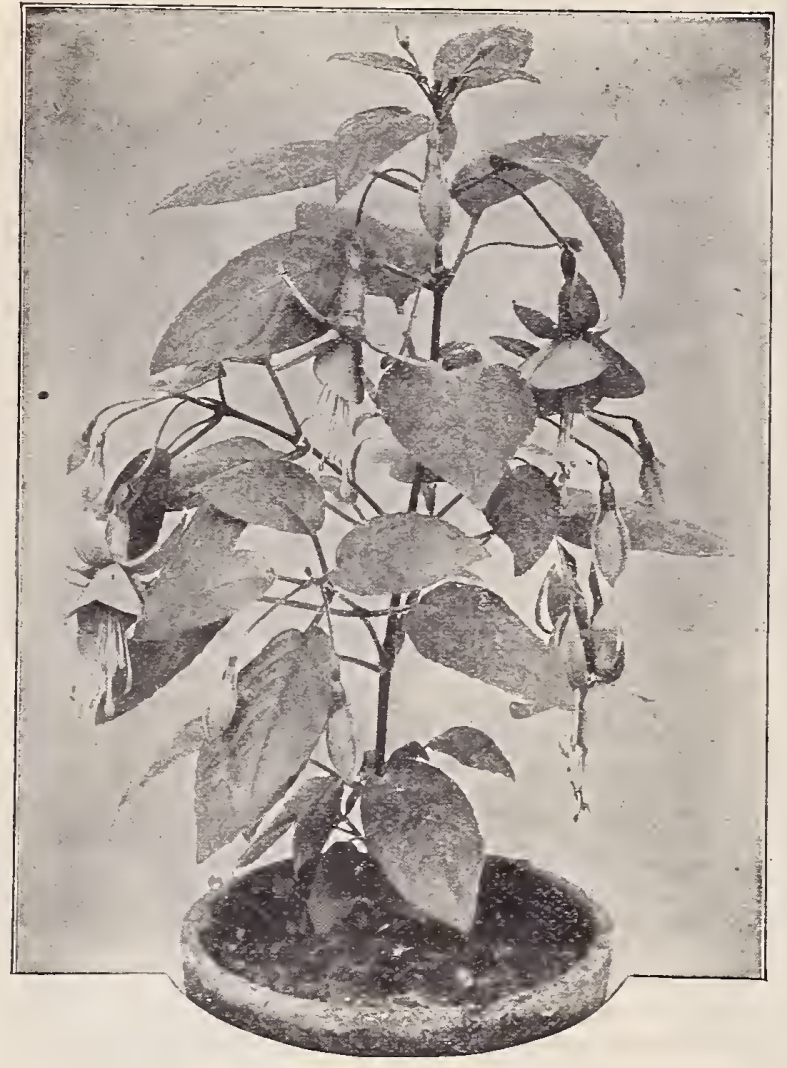

FUCHSIA, LITTLE BEAUTY

\section{FUCHSIA}

No class of plants is more graceful and elegant than the Fuchsias. The striking contrast of their colors, - white, carmine, rose, and purple,-renders them perfectly charming. Each, I5 cents; dozen, \$1.50.

Avalanche, Corolla violet; sepals crimson.

Bouquet. Flowers of beautiful form; sepals a clear coral color : corolla blue. Jeanne Summary. Tube and sepals bright crimson scarlet, corolla white. Jupiter. Tube and sepals scarlet; corolla ricb royal purple. Extra large size. Little Beauty. Tube and sepals bright red; corolla rich purple.

Mary. The drooping flowers, over two inches long, are a brilliant crimsonscarlet, and stand out prominently against the dark green foliage.

Rosains Patrie. Tube and sepals carmine. Corolla white.

Storm King. Dwarf grower. Tube and sepals rec.. Corolla white.

Victor Hugo. Flowers large, very double; sepals bright crimson; the center or corolla violet-purple, marbled with red. A unique and beautiful flower.

\section{GERANIUMS}

Each, 15 cents ; three for 40 cents ; six for 80 cents ; dozen, \$1.50.

\section{DOUBLE.}

Alphonse Ricard. Bright orange-red. Trusses very large.

Beaute Poitevine. The color is a bright salmon-pink.

Countess de Harcourt. Pure snow-white.

Heteranthe. Bright scarlet.

Jean Viaud. Flowers semi-double, brilliant rose, beautiful white spots.

La Pilot. Very dark scarlet.

M. Anatole Roseleur. Deep rose pink.

Madame la Comtesse de Baume. A charming bright pink

Madame laulin. Center of flower delicate pink, bordered with pure white, Madame Recamier. Snow white.

Madame Landrey. Clear salmon, center shading to copper, with white eye. Madame Buchner. Double; snow-white. A strong grower.

S. A. Nutt. Double. Brilliant deep blood-red, with maroon shadings. Kather tall ; vigorous grower. Truss large. One of the finest bloomers.

Toronto. Bright salmon. Flowers and truss of large size. A grand bedder

\section{GERANIUMS-Continued}

SINGLE.

A. Carre. Crimson scarlet. Jules Lematrie. Light pink.

General Grant. Popular old sort. Jumbo, Very fine scarlet.

Marguerite de Layre. A fine, strong, free grower; pure white flowers. Mrs. E. G. Hill. Brigbt salmon with light shading at center.

\section{TRICOLOR.}

Mrs. Pollock. Leaves variegated; flowers scariet.

DOUBLE IVY-LEAF.

This class has thick, glossy, Ivyr-shaped leaves. The plants are drooping in habit, and excellent for baskets, vases, and house plants.

Jeanne d'Arc. White, suffused with lavender. Double.

Leopard. The color is clear lilac-pink, the upper petals being heavily blotched with deep crimson, and marked with maroon duts.

\section{SWEET-SCENTED.}

Dr. Livingstone. Leaves finely divided, very fragrant.

Rose. This is the most desirable of the scented varieties.

\section{BRONZE}

The leaves of the Bronze Geraniums show the most beautiful shades of yellow or brownish red, the folixge being as bandsome as the flowers.

Black Douglas. Flowers salmon. Foliage golden yellow; red zone.

Exquisite. Leaf light yellow ground, chocolate zone. Flowers salmon.

\section{PELARGONIUM}

\section{Lady Washington Geranium}

The New Everblooming Pelargonium, Easter Greeting

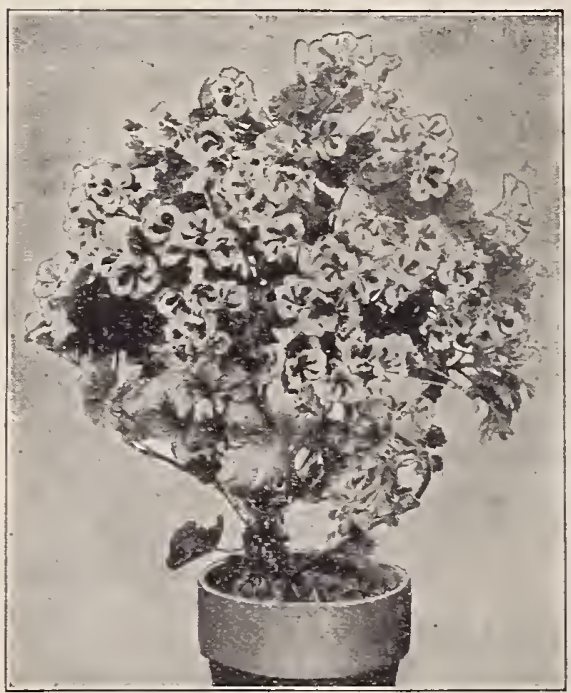

PELARGONIUM, EASTER GREETING
The flowers of Easter Greeting have the large size and the gorgeously rich coloring of $\mathrm{the}$ "Lady $\mathrm{W}$ ashing. ton Geranium. Io this is added, in Easter Greeting, the habit of cuntinuous blorming, which dinaty bedding geranium so highly valued. Easter Greetirg is the first of a new race and one of the most valulable introductions in recent years. As an Easter plant it rivals the Ara. lea: but unlikes be Azalea, Easter Greeting, will remain in fullbloom all smmmer

Each, 25 cents. Dozen, \$2.50! has made the or-

\section{OLEANDER}

Splendens variegata. Large double pink flowers: early. Glossy green leaves with a broaj margin of creamy white. Fach, 25 cents.

Double Pink. The old variety. Each, 25 cents.

\section{OTAHEITE ORANGE}

The great beauty, novelty, and popularity of this plant are indeed wunderfinl. It blooms most freely during winter, though it is likely to bloom at any and all times of year. WVith one or two pots of it anyone can raise an abundance of delicate and fragrant orange blossoms. It is a dwarf orange, which grows, blooms, and fruits freely in pots. Fruit about one.half the size of ordinary oranges.

Strong plants, each, 20 cents; extra strong plants, each 35 cents. 


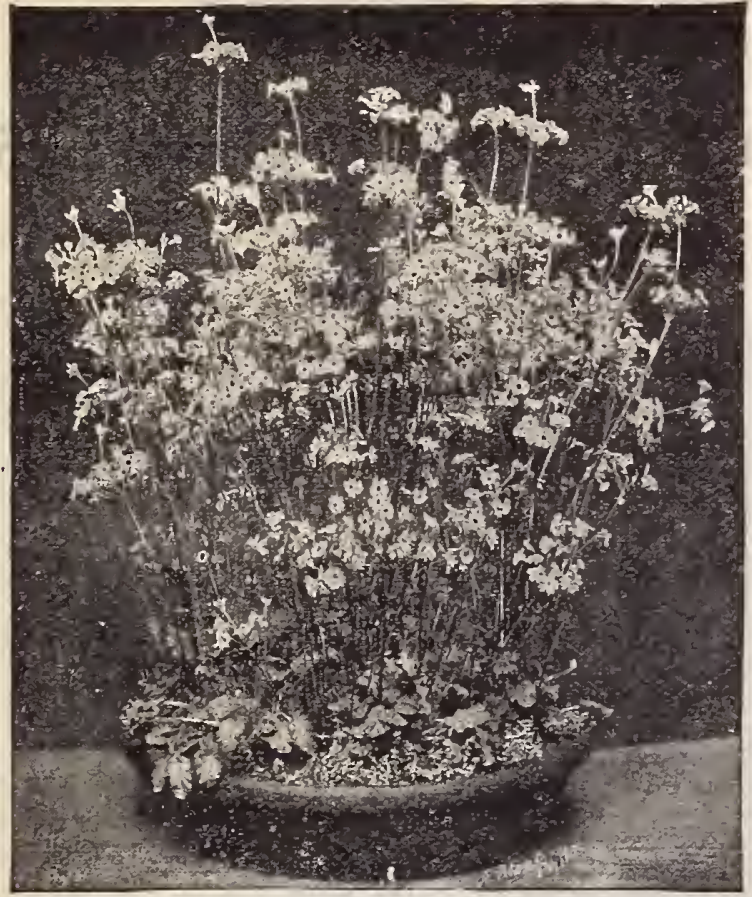

BABY PRIMRUSE

Primula Forbesi. Baby Primrose. Needs but little care. It forms a dense rosette of fleshy leaves, from which spring the flower stems about iz incbis tall; delicate rosy-lilac flowers produced in great abundance.

Each, 20 cents; two for $3^{\circ}$ cents.

Primula obconica grandiflora. Perpetual blooming, bearing large trusses of flowers on long stems, well above the foliage; color a pale lilac and pink Each, 20 cents; dozen, $\$ 2.00$.

Mexican Primrose. A charming plant, wbich in freedom of bloom excels all others. Flowers almost three inches in diameter, cup-shaped; color bright pink, with scarlet veins and large, showy white center. A plant of easy culture.

Each, 15 cents; two for 25 cents.

\section{PALMS}

First size, \$1.25; second size, 85 cents; third size, 35 cents.

First size, eighteen to twenty inches high; second size, eight to tuelve inches high; third size, strong young plants from three-2nch pots.

Sent by Mail or Express, charges prepaid, at prices quoted. Kentia Belmoreana. Graceful arching leaves, with long, terete, shining, yellowish-brown petioles: divisions of the leaves, twenty to thirty in mum ber, strap-shaped, deep green in color. This palm will stand a great rleal of ill-usage and maintain a good appearance.

Kentia Forsteriana. The beautiful "Thatch Palm," similar to the Kentia Belinoreana, but the petioles are a brighter green and the leaf divisions narrower, more delicate and graceful. A handsome Palm for table decoration.

\section{OXALIS}

Ortgiesi. Golden Star. An attractive plant that is always in bloom, and requirs no special treatment. The clusters of star-sbaped flowers are bri.ht gulden yellow. Underside of the dark olive leaves a bcautiful crimson. Each, I5 cents ; dozen, \$I.25.

\section{PETUNIA}

Single, Vick's Ruffled. These plants are from seed of our own growing, and we recomniend them as being very fine. The flowers are richly colored, very large and beautifully fringed.

Each, 15 cents; two for 25 cents; dozen, $\$ 1.25$

Single Fringed. Flowers nicely fringed.

Each, Io cents; three for 25 cents; dozen, 81.00 .

\section{RUBBER PLANT}

Ficus elastica. This is certainly one of the best plants grown for table or house decoration. It succeeds well with ordinary treatment. 'l'be glossy green leaves resist the dirt and gas to which plants in dwelling houses are exposed. Strong Plants, each, 50 cents; larger plants, each, 75 cents and $\$ 1.00$.

\section{SALVIA}

Each, 15 cents; dozen, \$1.50.

Clara Bedman or Bonfire. A dwarf early blooming variety. The plants are almost hidden by the mass of brilliant scarlet flowers.

Splendens. The well-known Scarlet Sage. A splendid flowering plant with plumes of dazzling scarlet flowers.

\section{UMBRELLA PALM}

Cyperus alternifolius. A beautiful, easily-grown plant, that is admirably adapted to many different modes of culture. It makes a very show y plant for pot culture, is one of the best for ferneries, while for the aquarium it is without an equal. Each, 15 cents; three for 30 cents.

\section{CLIMBING} GERMAN IVY

Each, Io cents; three for 25 cents.

A fine, thick-growing trailing plant that is unsurpassed for use in hanging baskets and urns, where delicate green fuliage is needed.

\section{IPOMEA, Moonflower}

\section{Each, 20 cents; dozen, $\$ 2.00$.}

Ipomoa Bona Nox. It is a beautiful, vigorous climber, producing large, pure white, sweet-scented fowers at night and on dull, cloudy days. 'To keep overwinter, the plant must be cut back, the roots potted, and kept in growing conclition.

Ipomoea Leari (Blue Moonflower). Flowers six inches across, of intense violet-blue, with reddish plirple rays.

One plant, each, of Ipomœa Bona Nox and Leari for zo cents.

\section{JASMINE}

Jasminum grandiflorum. $\Lambda$ favorite greenhouse climber or house-plant, and one of the sweetest of fiowers. Foliage fine; white, star-shaped fragrant fowers from November to May. Easy o1 culture. Each, 20 cents.

\section{NASTURTIUM, Double \\ Each. 20 cents}

Flowers perfectly double, and borne in great numbers the whole year. Golden Wonder. The color is a brigbt golden yellow, witb a dash of scarlet in the center of each petal.

Sunbeam. Flowers a beautiful shade of bright orange-red. One plant of each of the two varieties for 30 cents.

\section{TRAILING VINES}

\section{MANETTIA VINE}

Manettia bicolor. A beautiful twining plant; flowers from one; to $t$ wo incbes in length, of the most intense fiery scarlet, with bright yellow tip. As d put plant to train on a trel!is it is unrivaled. In the open ground it succeeds amirably. Each, 20 cents; two for 30 cents.

OTHONNA

Crassifolia. A neat drooping plant for hanging baskets. Yellow flowers Each, ro cents; three for 25 cents.

PASSIFLORA, Passion Vine

A class of rapid growing climbing plants well adapted for house culture in winter or for training over porches, etc., during summer. The flowers are about four inches in diameter, with pear-shaped petals.

Constance Elliot. Flowers pure white. Each, 15 cents; two for 25 cents

\section{PILOGYNE SUAVIS}

A splendid climber for screens and verandas; also fine for hanging baskets. Each, 15 cents; two for 25 cents; dozen, $\$ 1.25$.

\section{SMILAX}

A well-known and popular climber. Foliage of a dark glossy green, used largely with cut flowers, wreatlss, etc. Excellent for parlor or window culture, '1ender. Each, 15 cents, dozen, $\$ 1.50$.

\section{VINCA}

Major variegata. A heautiful trailing plant, admirably adapted for hanging baskets and vases. The leaves are glossy-green, broadly margined a creamy white: flowers blue.

Each, 10 cents; large plants, with vines two to three feet, 25 cents. 


\section{SUMMER FLOWERING BULBS}

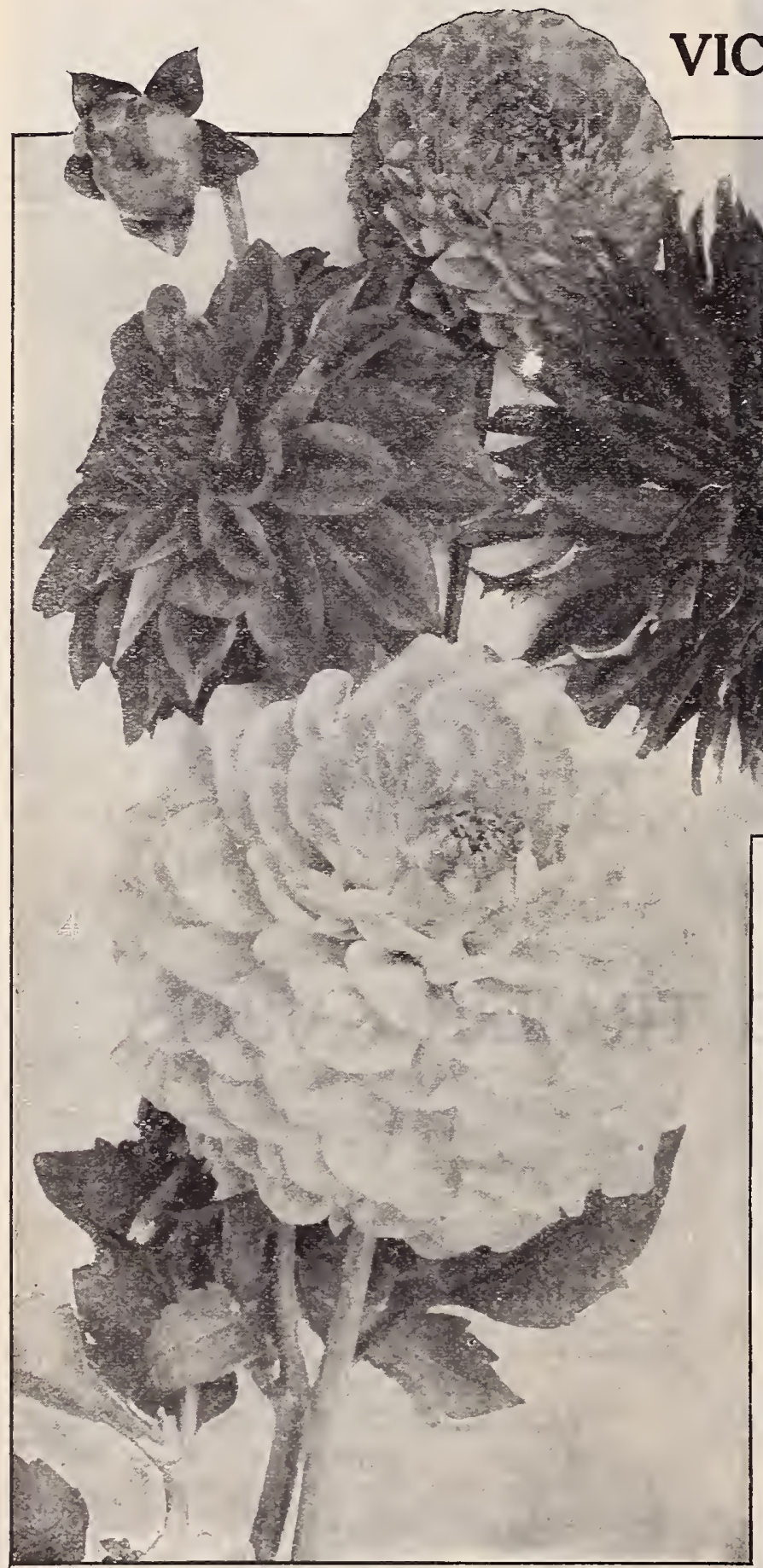

I. Pompon Dahlia. 3. Decorative Dahlia

2. Cactus Dahlia. 4. Show Dahlia.
No flowers are easier to grow, or respond more readily to care and attention, than Dahlias; liut three things are of prime importance; a moderately rich soil, sunshine and water. Plant about May Ist, covering the tubers three inches deep. If many shoots start up, thin them out to one or two. When the plant is six inches high, cut it off above the second joint. This will cause it to throw out four branches, making a strong,bushy plant, , hich will withstand wincls and produce flowers freely. Cultivate well until they legin blooming; after that stir only the surface soil, and then just enoitgli to prevent a crust forming.

\section{Cactus Dahlias}

The Cactus Dahlias have large, loosely-formed flowers. The long, narrow petals are variously rolled or twisted. The flowers many of which are nording on slender stems, are the most graceful and artistic of all the Dalilias.

Each, 20 cents; dozen, $\$ 2.00$; except where noted. Mail or express prepaid.

Alpha. White, spotted and striped purple.

Claja J. Stredurick. Salmon-flesh, shaded darker. Very large, with long narrow pointed petals. Oue of the best.

Countess of Iomsdale. Rich salmon, tinted apricot. One of the easiest of all the Cactus Dahlias to grow, and last season produced more blooms than any uther Cactus Dahlia on our farm.

Dainty. Primrose, shaded and tipped, soft pink. A delicately beautiful flower.

Earl of Pembroke. Dark rich shade of reddish purple.

Frute. Rose pink, cream center.

Kriemhilde. An exquisite combination of ivory white and pink. "Queen of the Cactus Dahlias."

Keynes White. Fine white of perfect shape.

Matchless. Dark, velvety maroon. Each, 15 cents; dozen, \$1.50. Mrs. H. J. Jones. Crimson-scarlet striped with cream. Varies from solid crimson to cream color on the same plant.

Mrs. J. J. Crowe. Clear jellow; fine habit and form.

Priucess. A rich blending of rose and soft pink. Flowers of collosal size and very free.

Standard Bearer. Brilliant Scarlet. Medium size. Very free flow. ering.

Folker. Pure Yellow. 


\section{Decorative Dahlias}

Decorative Dahlias are intermediate hetween Cactus and Show. The massive flowers are not so glohular as those of the Show and the petals are hroad and somewhat flattened.

Each, 20 cents; dozen, $\$ 2.00$; except as noted. Mail or express prepaid.

Black Prince. Dark velvety maroon. Large flowers. Each, 15 cents ; dozen, $\$ 1.50$.

Catherine Duer. Fine red, a favorite for cutting.

Clifford W. Bruton. Canary yellow. Large, long stemmed flowers. One of the finest Decorative Dahlias.

Constancy. Rich reddish orange, shaded hronze. A strong.and vigorous grower and profuse hloomer. Each, I5 cents; dozen, \$1.50.

Eloise. Pink, center of flower blush white.

Gloriosa. Bright glistenıng crimson scarlet.

Harry Freeman. l'ure White.

Iridescent. Metallic hluish tints on red ground. Free flowering.

Jack Rose. Rich glowing crimson. Color of the favorite old rose, General Jacqueminot. Early and profuse bloomer.

Keystone. Lilac ground penciled with crimson. Fine large flowers.

Lyndhurst. Rich glowing, clear, deep scarlet. Fine long stemmed flowers.

Mrs. Hartong. Light fawn suffused with pink. Large. Fine form. Each, I5 cents, dozen, \$1.50.

Ir's. Hoosevelt. Delicate light pink. Immense double flowers of graceful form Free flowering. A magnificent variety. Each, 30 cents; dozen,\$3.00. Nymphæa. Light shrimp pink, almost white. The "Water Lily Dahlia." Robust plant and large heautiful flower.

William Agnew. Brilliant glowing, light scarlet. Beantiful large floweis. Zulu. Kightly named the "Black Dahlia." Each. 15 cents; dozen, \$1.50.

\section{Show Dahlias}

The old fashioned douhle Dahlia. Ball-shaped flowers; the petals quilled or tuhular. As a class they are more formal than the Cactus or Decorative. 'lhey still retain their old-time popularity, on account of their long stiff stems and their lasting qualities as cut flowers.

Each, 15 cents; dozen, \$1.50. Mail or express prepaid.

A. D. Livoni (Ethel Vick.) Soft sèa shell pink. A splendid cut flower. Ada Tiffin. Light peach, tinted rose.

Arabella. Pale primrose, tipped lavender and shaded rose. A charming color and all early, free hlooming flower

Bird of Passage. White, tipped with pink

Emily. Lavender. Flowers of great size on long stems. A grand variety and a very free hloomer.

Frank Smith. Deep velvety maroon, each petal distinctly tipped with white. Very striking and attractive.

Maid of Kent. Cherry red, tipped with white.

Millev's Hed. Dark crimson scarlet. Large and free flowering

Miss Thatcher. Sulphur yellow.

Penelope. White daintily flaked light lavender. Good size and free hlooming. Purity. A beautiful white.

Queen of Yellows. Clear, deep yellow. A splendid flower for cutting.

Red Hussar. Brilliant glowing scarlet. Lighter shade than Miller's Red alid nut quite so large. Free flowering.

Red Warrior. Rich crimson.

Stomm King. Pure white. Very early and a most profuse hloomer. Thomas White. Dark crimson ,naroon.

White Swan. White. A magnificent large white flower.

\section{Pompon Dahlias}

The ball-shaped flowers of the Pompon Dahlias are a littlesmaller than these of the Show class, and are borne in the greatest profusion on long slender stems. They are earlier than the larger classes.

Each, 15 cents; six for 75 cents. Mail or express prepaid. Catherine, Pure lemon yellow.

Eleganta. Deep soft pink, edged rose.

Daybreak. Soft shell pink.

Fairy Queen. Sulphur yellow, edged deep peach.

Little Beauty. Delicate shrimp pink.

Prince Charming. Creamy white, tipped pink.

Snowciad. White, early and profise hloomer

Vivid. Bright fiery scarlet. A prolific hloomer.

White Aster, Pure white, splendid for cutting.

\section{Amaryllis}

The Amaryllis produces show flowers that are handsome and very attractive resembling Lilies. The hulhs should be potted in a rich, sandy loam, with good drainage. They require abundant moisture when growing, but at their season of rest water should he given sparingly

Fragrans. Flowers three to four inches long ; yellow; fragrant; stalks 15 to 18 inches high. Each, I5 cents.

Regine. Equestre. One of the best of the Amaryllis family for winterhlooming. Flowers large, bell-shaped; color light scarlet, throat or center white. Each, ro cents.

Johnsoni. An elegant pot plant, with crimson flowers five inches in diameter, each petal striped with white. Flower-stalks two feet high, with clusters of three to five hloons. Each, 50 cents.

Formosissima. Jacobean Lily. Eight to ten inches high. Flowers dark crimson. The hulbs are dormant during the winter. Each, 15 cents.

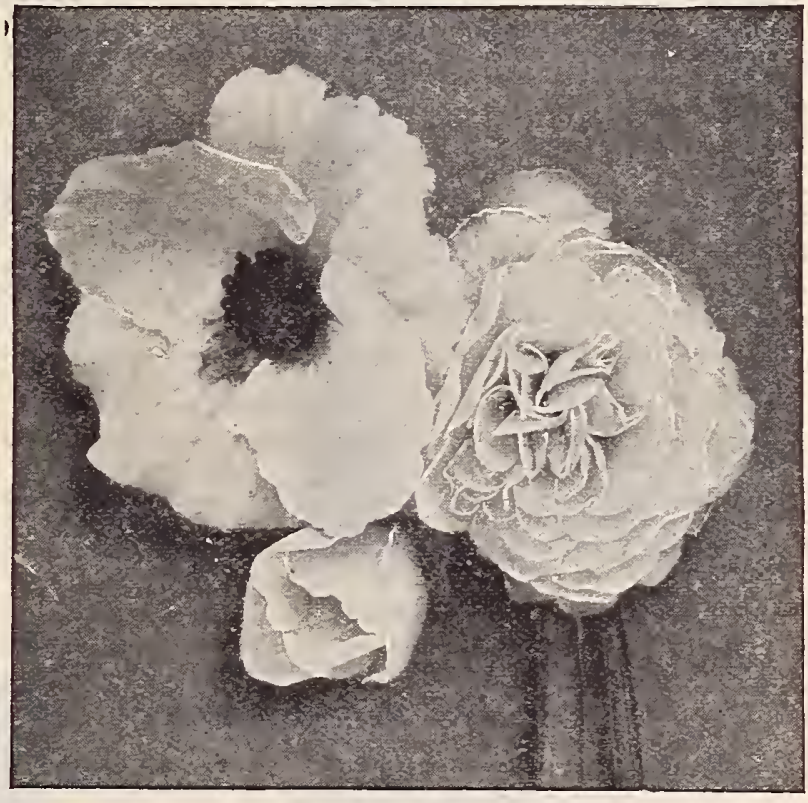

\section{Tuberous Begonias}

No plant equals these Begonias for growing in partly shaded places. Blooms continuously from June to October.

The flowers are brilliant, handsomely formed, and of wonderful size, often measuring from four to six inches in diameter. The plants are easily grown and are fine either as pot or bedding plauts. After the blooming season is cver the tubers are dried and either left in the pots or placed in dry sand and kept until spring, to he started again in February or March.

Single Five colors, affording a charming selection for contrasting colors Ingle in hedding. White, Crimson, Scarlet, Rose, Yellow. Each, 10 cents; three for 25 cents; dozen, 75 cents. The set of five for 40 cents.

Double The same colors as fornd in the single Begonias, hut the hlooms Rase, Yellow. Each, 20 cent; t wo for 30 cents; five for 60 carlet, dozen, \$1.25.

Bearded Begonia B. grandiflora erecta cristata. This good size, bearing on each petal a dense crest or heard coingosed of curiously twisted threads. Mixed colors. Each, 20 cents; two for 30 cents.

\section{Calla}

Little Gem. A dwarf variety of the old Calla, ter to twelve incles higb : free hloomer. Each, 15 cents; two for 25 cents.

Spotted Calla. Alba maculata. Beautiful for pot culture. The foliage is marked in the same manner as that of the Vellow Calla. 'I he bulhs must be kept in dry sand in the winter. Each, 10 cents; dozen, \$r,00, 


\section{GLADIOLUS}

There is no other summer-flowering bulb so satisfactory, needing so little attention and thriving so well in almost any ordinary soil, as tbe Gladious. The bulbs should be set from three to six inches apart in rows, or, for massing, six inches apart, and about four inches deep. Plant from middle of A pril to first of Jine. In the fall, before hard frosts, take up tbe bulbs, remove the tops, dry in the air for a few days, and store in some cool, dry place, secure from frost, until spring. Our list is a selection of the cream of bundreds of varieties which are grown on our own farm, under our own supervision.

America. The most popular Gladiolus in cultivation. Splendid large flowers of a beattiful clear flesh pink color. The petals are well rounded, the flowers broadly opened, and the fine showy spike is of good length. The plants are vigorous growers, not subject to disease, and make extra good bulbs.

Attraction. Flowers very large. A beautiful soft color, betwcen rose and scarlet. The large throat is pure wbite.

Augusta. Fine white, faintly tinged with lavender. Free bloomer and had a long season, producing many side branches.

Beauty. Earliest of all. Light pink with chocilate throat.

Brenchleyensis. Vermilion-scarlet. Fine old variety. Early, vigorous and a free bloomer.

Eugene Scribe. The large, well opened flowers are a soft rose-pink heavily flaked with brigbt carmine. Edges of flowers ruffled. Large spikes.

Independence. A brilliant rose pink, witb richly marked throat, a long strong spike of wax-like flowers. One of the best.

Isaac Buchanan. Light yellow, flushed with deeper color.

Jean Dieulafoy. Early. Large flowers of creamy pink. Laige blotch of bright crimson in throat.

Madam Monneret. Soft pure pink; a little carmine in the throat.

May. Beautiful light flesh pink, flaked with carmine at thre edges. A good

Mephistopheles. Very striking. Deep scarlet heavily marked with yellow and dark crimson.

Mrs. Beecher. Very large flowers of deepest scarlet. Eary and a strong grower.

Shakespeare. Light pink suffused with carmine.

"1 900." Rich, deep scarlet with large white blotch. Hardy and free flowering. A splendid, late blooning variety.

\section{Any Variety Named Above}

Each, 10 cents ; three for 25 cents ; six for 40 cents ; dozen, 75 cents.

Baron Hulot. Dark, velvety, violet-blue. Best of the blues. Each, 15 cents : three for 40 cents; six for 75 cents; twelve for $\$ 1.40$.

Canary Bird. Clear canary yellow, without markings. The best yellow. Each, IS cents; three for 40 cents; six for 75 cents; twelve for $\$ 140$. Cardinal. Intense cardinal scarlet. Deep, rich color and large flowers. Each I5 cents; three for 40 cents; six fo 75 cents; twelve for \$I.40.

\section{Kunderdi Glory} ductions of recent years. Each petal is distinctly ruffled at tbe edge. The immense fowers are a beautiful cream-pink color. Leaves very broad. Strikingly distirct in plant and flower. The stock we offer was all grown on our own farm the past year. Each, I5 cents; six for 75 cents; twelve for $\$ I .40$.

Meirose. One of the largest Gladioli in cultivation. Light pink ground, flaked with rose. Very desirabie. Each, 20 cents; six for $\$ 1.00 ;$ twelve for $\$ 1.70$.

Peace. The flowers are extra large, of perfect form, on a heavy, straight spike. Color a pure white, with pale lilac featherings on the interior petals. A charming flower, either singly or for massing: The bulb is large and the plant is a remarkably strong grower. Each, 25 cents.

Primulinus. A rare species from South Africa. The flowers are small, of a primrose yellow color, and borne on tall, slender stems. Hlooms the whole season. Each. 25 cents ; six for $\$ 1.25$; twelve for $\$ 2.25$.

Princeps, Immense, broadly open flowers of clear, brilliant scarlet. The "Amaryllis flowered" Gladiolus. Each, 20 cents; six for 85 cents; twelve for $\$ 1.40$.

Rosella. Very large flowers of deep rose color. Each, ro sents; three for 35 cents; six for 40 cents; dozen for 75 cents.

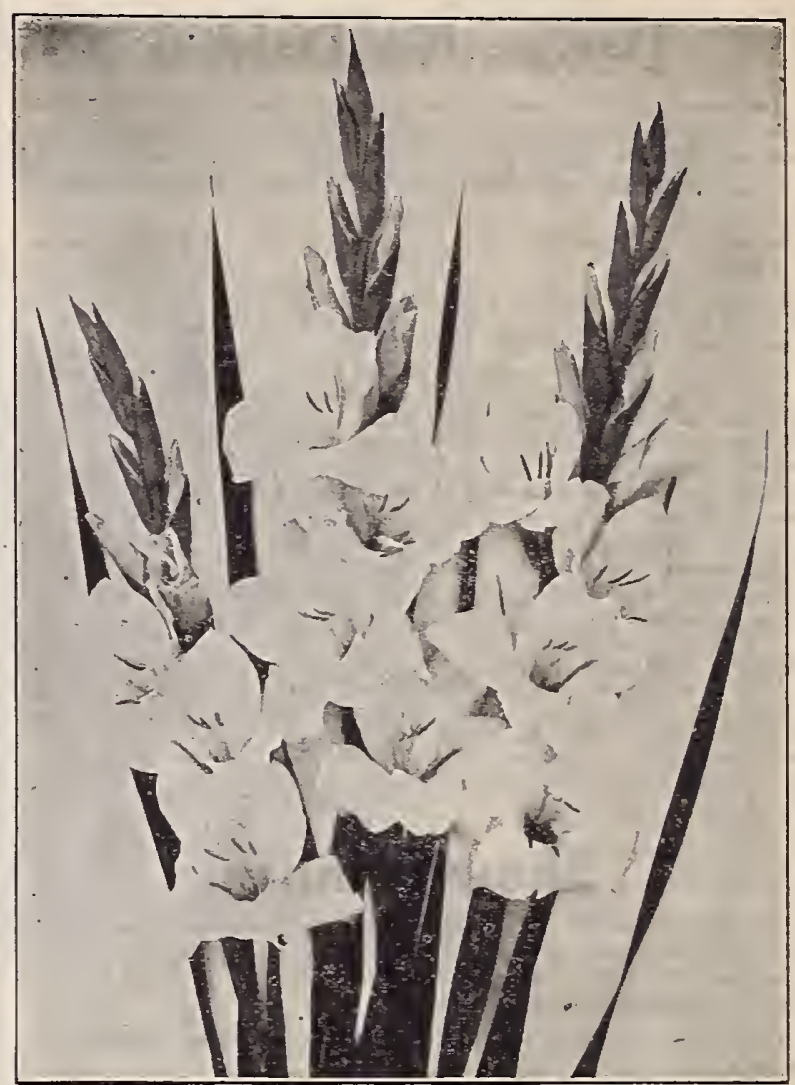

GLADIULUS, AMERICA

\section{COLLECTIONS}

In order to give our customers an opportunity to make their own collections of standard varieties at mollerate cost, they may select : Any 3 (all different), priced at 10 cents, for . 25 cents Any 6 (all different), priced at 10 cents, for. 45 cents Any 12 (all different), priced at 10 cents, for. 80 cents

\section{MIXTURES}

Vick's Named Mixture. This is a mixture of over I50 named varieties to which we are adding every year. It comprises every class, and will furnish a profusion of bloom from July till frost. Many of these varieties cost us several times as much as we charge for the mixed

Six, 30 cents ; dozen, 55 cents ; hundred, $\$ 4.00$; charges prepald.

Choice Mixed. All colurs in fine assortment. Six, 20 cents; dozen, 30 cents; hundred, $\$ 2.00$; charges prepaid.

\section{GROFF'S HYBRID GLADIOLI}

\section{In Mixtures Only}

This race of Gladioli contains many striking shades. The plants are more robust than those of the standard, or Gandavensis type, and the flowers are larger, more spreading and have broader throats. The famous "Anerica" is one of the many' choice varieties taken from Groff's Hybricls.

Light and White Hybrids. Beautiful collection of light and dainty slıades. Six, 30 cents; dozen, 50 cents; huncred, $\$ 3.50$; prepaid.

Red Hybrids. All shades of red, scarlet and crimson. Six, so cents; dozen, 50 cents; hundred, $\$ 3.50$; prepaid.

Blue Hybrids. Includes all the shades of clematis, lilac and beliotrope; a beautifulstrain. Six, 45 cents; dozen, 80 cents; hundred, $\$ 6.00$.

Mixed Hybrids. All shades in grand mixture, Six, zo cente; dazea, 5o cents; huadred, $\$ 3.50$. 


\section{G L A D I O L US}

ROCHESTER WHITE

The Purest White Gladiolus Ever Offered.

Rochester White is in a Class by Itself.

Lovers of fine Gladioli will be pleased to know that through the sticcessful efforts of James Vick's Sons, as distributing agents, growers, everywhere, are now able to buy this magnificent variety at a moderate price. This will, we are sure, lead to its being at once very widely introduced.

Rochester White has been highly commended by every authority on Gladioli, both in this country and in Furope, and it has been awarded first prize at every one of the many plices wbere it nas been shown in competition. Its unrivaled purity, its splendid habit, and its fine keeping qualities as a cut flower, conbine to make Rochester White an ideal exhibition variety.

The flower is a beautiful clear white throughout. It has no markings in the throat and even the anthers are white. The large, broadly opened blooms have nicely rounded petals, well arranged in an ample spike three feet in height. Tbey form bulbs of good size which produce strong, healthy plunts, comparing well in size and vigor with any of the standard varieties. See also novelty pages.

Each, 40 cents; three for $\$ 1.10$; six for $\$ 2.00$; dozen, $\$ 4.00$.

\section{CALADIUM}

Fancy-Foliaged. The fancy-foliaged varieties are very satisfactory for summer decoration. Leaves striped, blotchei, and spotted with white, crimson, and pink; in fact, the variety of color is something wonderful. In the fall the leaves die down, and the bulbs should be kept in the pots in a warm place. Each, 25 cents; dozen, $\$ 2.50$.

Esoulentum-Elephant's Ear. One of the stateliest of the ornamental-leaved plants, producing a splendid subtropical effect. Leaves frequently grow three feet in length and nearly as broad. Roots obtained in the spring will make good plants in the summer, and in tbe fall they should be taken up and stored in the cellar.

Medium-sized bulbs, each, 20 cents; dozen, $\$ 2.00$.

Large-sized bulbs, each, 30 cents; dozen, $\$ 3.00$.

Mammoth-sized bulbs, each, 40 cents; dozen, $\$ 4.00$

\section{GLOXINIA}

Gloxinias are among the handsomest of our summer-blooming greenhouse plants. The flowers are gorgeous, and the foliage has a velvety appearance. Bulbs should be started in spring in a warm place. They require partial shade and a liberal supply of water wben growing. After blooming, water should be withheld and the bulbs remain dry through the winter.

Four colors-Red, White, Blue, and Spotted.

Each, 20 cents; two for 35 cents; four for 60 cents; dozen, $\$ 1.50$.

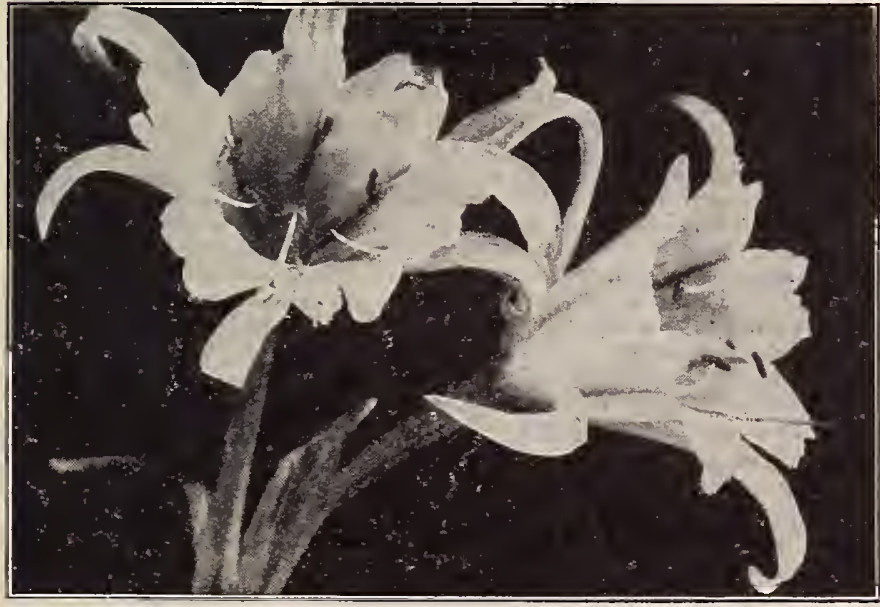

ISMENE

\section{ISMENE, Peruvian Daffodil}

Giant Ismene. The Ismene is one of the finest flowers of the stately Amaryllis family. I'he heavy bulbs send up stems two feet in height, on which are borne numerous large, pure white flowers. The flowers have a rich and striking appearance and are exceedingly fragrant. The Giant Ismene is easily grown and its beautiful and stately flowers are sure to give satisfaction. After the bulbs are ripened off they may be potted up and used for winter blooming.

Each, 20 cents; dozen, $2 . \infty$

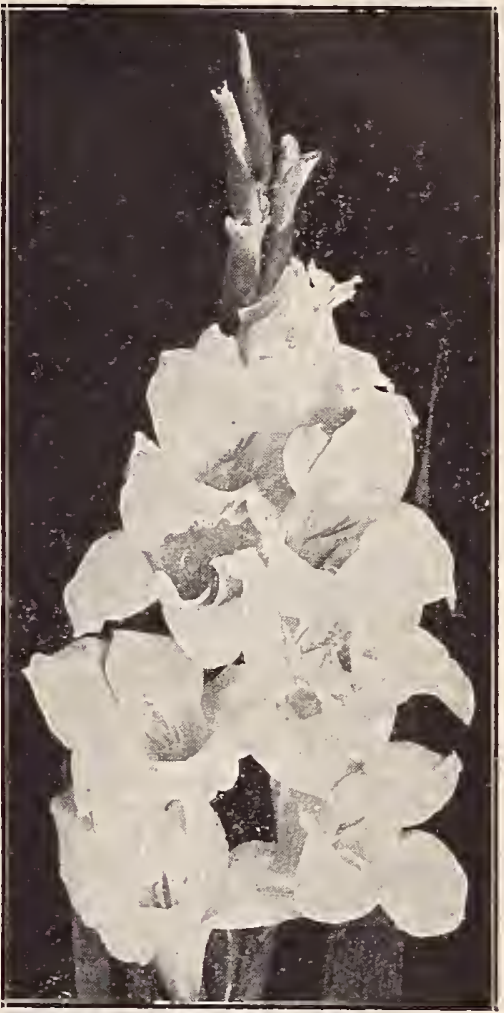

GLADIOLUS, ROCHESTER WHITE

\section{HYACINTHUS}

Candicans. Summer Hyacinth. A beautiful and stately plant, with stems three to four feet bigh. It has large, pure wbite pendant, funnel-shaped flowers, in long racemes. Very fragrant. In the North the bulbs should be dug in the fall and wintered the same as Gladiolus. Each, Ic cents; dozen, \$I.00

\section{MADEIRA VINE}

A charming climber for porches. The thick, dark green foliage forms a fire screen, and the white flowers are very fragrant. Tender. Strong bulbs, each, 5 cents; dozen, 50 cents.

\section{MONTBRETIA}

One of the most showy summer-flowering bulbs. Star-shaped fowers, produced in great numbers on long graceful spikes. Three for to cents; dozen, 30 cents; hundred, \$I.75.

\section{OXALIS}

Free-blooming bulbs, fine for pots, vases, or for edging walks and beds. Plant three inches apart.

Dozen, I5 cents ; hundred, 75 cents ; by mail prepaid.

Lasiandra. Rosy Crimson. Tetraphylla, (Deppei). Rosy lilac

\section{TIGRIDIA}

Tigridias are beautiful flowers, delicate as Orchids, and showing wonderfui blendings of colors. Plant bulbs in May and give the same care as to Gladiolus for winter.

\section{Each 6 cents; dozen 6o cents.}

Conchifiora. Yellow and orange, with dark spots.

Grandifora alba. A beautiful variety, with large showy white flowers marked at the base of each division with spots of a reddish brown color on yellow ground.

\section{TUBEROSE}

The Tuberose is a beautiful, pure white, wax-like, very sweetscented, double flower, growing on tall stems, each stem bearing - dozen or more blossoms. Our Tuberoses are all extra sized splendid bulbs.

Dwarf Tuberose, Pearl. Each, 5 cents; sixfor 30 cents; dozen, 35 cents; hundred, $\$ 2.50$. 


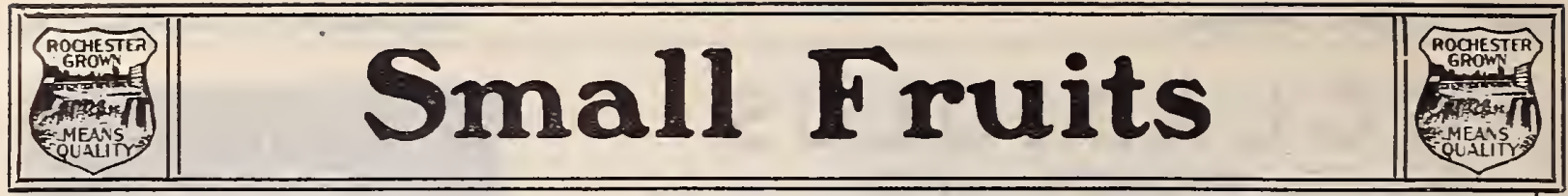

\section{STRAWBERRIES}

For field culture, plant in rows four feet apart, with the plants one foot apart in the row. For garden culture, plant three feet by one foqt. Should the ground not be prepared for planting on receipt of plants, they should be carefully heeled in, in a cool, moist, shady place. Do not sprinkle the foliage, as it causes a moisture to collect, which is very injurious to the crowns, causing them to rot. In setting the piants be careful to have the crowns even with or a little above the surface of the ground, and to have the trench or hole in wnich the plants are to be set deep enough to allow their roots their full length. Some varieties of Strawberries have pistillate or imperfect flowers. These must have perfect-flowered varieties planted every fifteen or twenty feet-among them, or they will produce mperfect fruit. The pistillate varieties are marked

At dozen and hundred prices we prepay postage or express eharges; at thousand rate customers will pay express or freight charges.

Dozen, 25 cents; $100, \$ 1.50 ;$ I000, \$5.00, except as noted.

Abington (P). Large, bright red, tirm and good quality ; holds its color wel
and continues bearing a long time. An improvement on Bubach. Dozen, 45 cents; 100, $\$ 2.50$; 1000, $\$ 10.00$.

Vick's Uncle Joe. Its fruit is perfect in form, of a dark, rich color, firm flesh, monstrous in size and uniform in shape. Amcng other attractive features, its early and continuous yield during the season is attributable to its strong, healthy and robust grow: Dozen, 50 cents ; twenty-five, 75 cents; hundred, $\$ 2.25$; fifty at bundred rate; thousand, $\$ 12.00$.

Climax. This very prolific strawberry originated with Henry W. Graham, of Maryland. In I900 he had 1,I00 plants, which he set on less than a quarter of an acre. In rgor he shipped 6,300 quarts, or about 20,200 quarts to tbe acre. Medium early: Dozen, 35 cents; $100, \$ 2.00 ; 1000, \$ 8.00$.

Early Beauty. Fruit medium to large. Productive and good quality. One of the best early varieties me have ever fruited. Dozen, 45 cents; 100 , $\$ 2.50 ; 1000, \$ 10.00$.

Echo. Superior to other varieties in both flavor and sweetness. Fruit brilliant red, of medium size, second early. Very productive.

Gandy. One of the best late Strawberries. Large, uniform size, rich crimStevens' Late Champion. The plants of this variety are of more than ordinary vigor: a good runner; perfectly healthy; color bright. A fine looking berry. Ripens after most other varieties bave gone. We consider it the best late strawberry. Dozen, 35 cents; $100 \$ 2.00 ; 1000, \$ 8.00$.

World's Wonder. As productive as the Haverland, but twice as large. Fruit is a bright red in color and does not turn dark after being picked. Uniform in shape, large size, good keeper and shipping berry. Ripens early and brings extra fancy price on market. Vines are strong, thrifty, and rapid in growth. Will protuce a large crop on either high or low land. The fruit is so firm and its keeping qualities are so excellent that it does not need to be picked oftener than once in three days. Dozen, 50 cents; hundred, $\$ 2.50$; thousand, $\$ 10 . \infty$.

William Belt. One of the very best for the home garden. Plants Fruit large, bright crimson. Ripens all over, no green tips. Juicy and sweet.

\section{OTHER STANDARD VARIETIES}

Brandywine, Jessie, Crescent (P), Glen Mary (P), Bubach (P), Mckinley, Wilsnn, Sample (P), Seaford $(\mathbf{P})$.

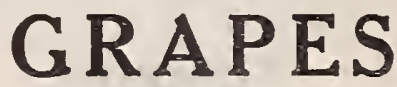

At the single and dozen prices we prepay mail or express charges. Hundred lots by express or freight, charges not prepaid.

Rows should be eight feet apart, and vines from six to eight feet apart in the row. Dig a hole two feet long, one foot wide, and one foot deep. Put a little surface soil in the bottom, and mix in some bone dust or commercial manures

Charges prepaid on all Small Fruits at the single and dozen prices. Hundred and thousand lots, charges not prepaid 


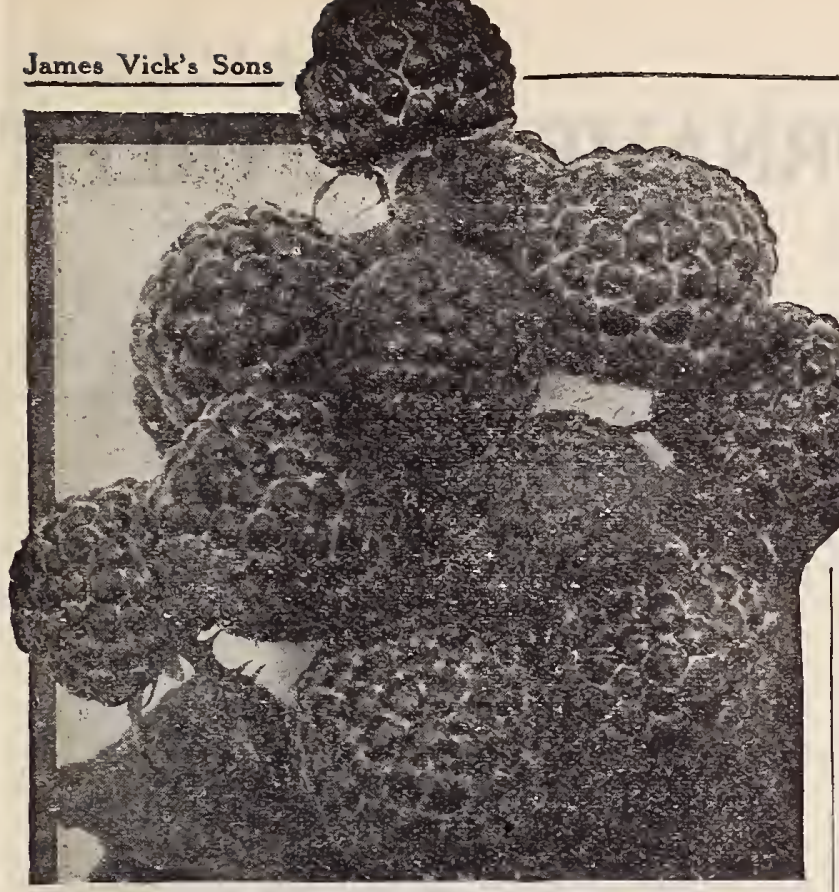

PLUM FARMER

\section{RASPBERRIES}

Blackcaps, and others that increase from the ends of the canes, should be plauted three and a half by seven feet. Keep the soil loose and free from weeds. When the canes attain the height of one foot, pinch off the ends; this causes the canes to branch, grow stocky and self-supporting. In the spring of the bearing year cut these back to within six inches of the main stalk. After fruiting, cut out all the dead wood. Red Raspberries and all others that sucker, should be set five by three and a half feet apart, when they must be cultivated both ways. Allow only three or four canes in each hill; treat all others as weeds. For garden culture set red varieties three feet apart each way, Black Raspberries four by three feet.

\section{RASPBERRIES, BLACK}

Each, 15 cts.; dozen, 75 cts.; hundred, \$2.25; thousand, \$15.00. Plum Farmer. above was taken from an actual photograph of a plant on our farm in I912.

"The plants are hardy, vigorous and productive; the berries large, good in color and quality. It his already been grown in some localities, and reports of its behavior are very favorable. It certainly should be given a trial in all commerciai plantations." -Report of Geneva Experimental Station.

The fruit ripens early; berries are large, thick meated, firm, juicy and sweet. In quality, firmness aud productiveness, it is all that can be desired either by wholesale growers or for the home garden.

Cumberland. Very hardy, having withstood a temperature of $16^{\circ}$ below zero. Very productive, making large crops of enormous berries Fruit unusually firm, and may be shipped long distances. Mid-season variety, coming ahead of the Gregg.

Gregg. Very large, fine quality, productive, late, hardy.

The Kansas. Early. Stands drouth well, and is uninjured by frost. Fritt is larger than that of the Gregg. Jet black, firm texture.

\section{RASPBERRIES, RED}

TU Fruit bright red, somewhat oblong, the largest of 1210 C. Ell red Raspberries. Flavor sweet and juicy. before Cutbbert. Holds its size well to end of season. In hardiness it easily takes first place. Plants very strong and vigorous.

Each, 20 cents; dozen, $\$ 1.50$; hundred, $\$ 8.00$.

Cuthbert. A valuable late variety; large, firm, and of superıor quality ; very productive. Each, I5 cents; dozen, 75 cents; hundred, $\$ 2.00$; thousand, \$12.00.

Miller's Red. One of the best early varieties. As large as Cuthbert. Brigh red. Flavor rich. Each, 20 cents; dozen, 80 cents; hundred, \$3.00.

Columbian. Popular for the home garden. Grows from eight to Perfectly hardy. Best for canning and evaporating; retaining color, form and flavor. Each, 15 cents; dozen, 75 cents; hundred, $\$ 2.25$; thous and, \$12.00.

\section{RASPBERRIES, YELLOW}

Golden Queen. Light amber. Each, is cents; dozen, 80 cents hundred, $\$ 5.00$.

Rochester, N. Y., The Flower City

\section{BLACKBERRIES}

At the single and dozen piices we prepay mail or express charges. Hundred and thousand lots by express or freight, charges not prepaid.

For field culture, plant in rows six feet apart and plants three feet apart in lie row. For garden culture, five by four feet.

Price, except as noted, each, 15 cents ; dozen, 80 cents; hundred, \$2.50; thousand, \$I5.00.

Blowers. (New) The giant of all Blackberries. An upright strong grower, very hardy and productive. Ripens about the middle of July and continues bearing for about two months. Each, 25 cents ; dozen, \$I.50.

Eldorado. Very vigorous and hardy; fruit large, of finest quality and without a liard core.

Minnewaski: One of the largest and most productive. Early. Rathbmn. Fruit extra large. In quality it surpasses the luscious I)wberry. Being without the hard core common to Blackberries, it bearer. Fruit large throughout the season. As a shipper it is unsupassed. Snyder. An exceptionally hardy variety. Berries medium size, produced abundantly ; sweet, juicy, and, when fully ripe, without a hard core.

\section{GOOSEBERRIES}

Gooseberries thrive best if planted where they will receive a partial shade. Plant five feet each way. Gross feeders, liking a deep rich soil.

At single and dozen prices we prepay postage or express charges. Chautauqua. Fruit a light yellow (nearly (White), free from spines and hair Thick-skinned, sweet, and of exquisite flavor. Equal to any other variety on the market. Each, 50 cents; dozen, \$3.50.

Downing's. A native seedling; vigorous, hardy, and prolific; free from mildew. Hruit greenish white, large. Each, 25 cents; dozen, \$1.75.

Industry. A valuable new foreign variety. Fruit dark red, very large, and of a rich agreeable flavor. An immense yielder. Each, 30 cents; Doz., 2.50. Pearl. Grown from seed of Houghton, crossed with Ashton Seedling. Worthy of special notice because of its good zuluality, productiveness, and freedom from mildew. Each, 25 cents ; dozen, \$1.75.

\section{CURRANTS}

Choose a moist, rich soil for Currants. Plant five feet apart each way. Keep free from weeds and grass by liberal cultivation and mulching. Use plenty of manure and trim out superfluous wood by cutting back the new growth twothirds each year. Keep the foliage free from worms by using white hellebore. Each, 20 cents; dozen, $\$ 1.25 ;$ hundred, $\$ 7 . \infty$.

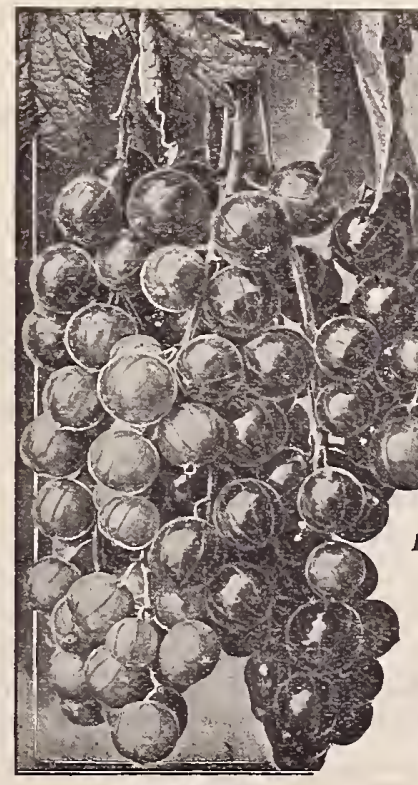

PERFECTION
Cherry. Large and productive. Standard for market.

Black Champion. An English variety. Extra good for jams, etc.

Fay's Prolific. One of the best; very pro. ductive; large; g o od flavor, early.

Red Cross. A fine variety. Plants strong, vigorotis, remarkably productive. Clusters large, often measuring four inches in length ; berries large.

White Grape. Valuable for the table; quality excellent, mild, and sweet.

Pexfection. Color bright red; size as large as the Fay's or larger, the clusters averaging larger, the size of berry being well maintained to end of cluster. Rich, mild sub-acid, plenty of pulp, with few seeds. Less acid and of better quality than any other large currant in cultivation. The Perfection is a great bearer, superior to Fay or any other large sort. Strong 2-year plants, each, 30 cents; 2.50 per dozen. 


\section{VICK'S FRUIT AND ORNAMENTAL TREES \\ APPLES \\ WINTER PEARS}

Our list embraces a careful selection of the best for the several seasons and thosethat have proved worthy of general cultivation. Those starred $(*)$ are tbe Russian and hardier varieties.

40 cents each, $\$ 4.00$ a dozen, $\$ 30.00$ per hundred

\section{SUMMER}

Early Harvest-Medium, pale yellow, fine fiavor, sub-acid; very productive. July.

*Red Astrachan-Large, crimson, juicy, witb ricb, sub-acid flavor. Bears early; hardy. July.

* Yellow Transparent-The hardiest and finest early summer apple grown. Fruit large, pale yellow. July.

\section{AUTUMN}

*Duchess of Oldenburg $-A$ large, beautiful apple, round, streaked red on yellow ground; tender, juicy, very acid. Fine for cooking. September.

* Fameuse. Snow-Medium, deep crimson, flesh very white, tender, crisp and juicy, sub-acid. A popular dessert apple. October.

Maiden' $\forall$ Blush-Medium, "pale yellow, red cheek, fine quality, sub-acid, October.

\section{WINTER}

Baidwin-Large, roundish, skin deep red, flesh juicy, crisp, sub-acid, good flavor. Vigorous and productive Keeps splendidly. December to March. *Grimes' Goldea-Good size, yellow; higb quality. November to March. King-An apple of the largest size; deep red, round, flesh yellow, juicy, 2cid, tender. Always in demand. November to March.

*McIntosh Red-A very fine apple of the Fameuse class, hardy: large, dark red; flesb wbite, very tender, splendid quality. November to Feb.

Newtown Pippin-Large, round, greenisb jellow. Very high quality, juicy, crisp, tender, ricb, sub-acid. December to April.

Northern Spy-Crisp, tender, high quality, fine shape, beautiful coloring. Red, usually striped, sub-acid. November to Marcb.

Northwestern Greening-Very bardy, greenish jellow, large, mild, subacid. November to March.

Roxbury Russet-Nedium, dull green and yellow; flesh white, rich, subacid. November to March.

Talman Sweet-Medium, pale whitish yellow; flesh white. fine grained very hardy and productive. The best winter sweet apple for home and market. November to March.

*Wealthy-An American apple that is becoming very popular on account of itshandsome appearance and early fruiting. Hardy and productive. Fruit large size, roundish, skin smooth, splashed witb dark red; flesh wbite, tender, juicy, sub-acid. November to January.

Wine Sap-Medium, deep red; firm, crisp, high flavor; popular in South west. December to May.

\section{CRAB APPLES}

Transcendent-Large, yellow with ricb crimson cbeek. An improved Si. berian crab. September.

\section{SUMMER PEARS}

50 cents each, $\$ 5.00$ a dozen, $\$ 30.00$ per hundred

Bartiett-Iarge size, rich, melting, delicious; everywhere successful. Blossoms sterile, requiring other varieties planted near by to insure fertilization. September.

Clapp's Favorite-Very large and showy, golden sellow with red cbeek Ripens a week before Bartlett. Rots at the core unless picked ten days before ripe. August.

Wilder-Medium size, yellow with carmine sbading; fine grained, tender, subacid, August.

\section{AUTUMN PEARS}

50 cents each, $\$ 5.00$ a dozen, $\$ 30.00$ per hundred

Duchesse d'Angouleme-Very large, greenish yellow, tender, melting, buttery and juicy: does best as a dwarf. October.

Flemish Beauty-Large, sweet, melting; very productive, but liable to scab: very hardy. September.

Kieffer-Large, deep yellow with russet dots: juicy, sweet, coàrse; immensely productive ; early bearer. Fruit must he thinned to get the largest size. Fine for canning. Said to be blight-proof. Uctober and November. Seckel-Small, finest flavor; excellent for pickling and dessert; very pro. ductive. September.

Sheldon-Medium size, round, russet and red; melting, rich, very juicy and delicious; very productive; keeps well. October.
50 cents each, $\$ 5.00$ a dozen, $\$ 40.00$ per hundred Beurre d'Anjou-A grand pear: large, bandsome, buttery, melting, rich, yellow when ripe. The finest winter pear grown. Requires to bang late. Octuber and January.

Lawrence-Medium size, golden yellow, melting, very rich. The finest early winter pear. November and December.

\section{DWARF PEARS}

40 cents each, $\$ 4.00$ a dozen, $\$ 30.00$ per hundred Beurre d'Anjou-Early winter. Clapp's Favorite-Very early. Duchesse-Late fall, fine. Seckel-Extra fiue quality.

\section{CHERRIES--Sweet}

50 cents each, $\$ 3.00$ a dozen, $\$ 30.00$ per hundred Black Tartarian-Frit large, heart shape, dark purple, tender, rich; very prolific. Tree upright, vigorous and healthy. The best early black cberry. Napoleon-The largest size, yellow with red cbeek. Fery firm, juicy and sweet. Vigorous, upright tree; erormously productive. July.

\section{DUKES AND MURRELLOS-Sour}

Early Richmond-Medium size, bright red, acid, very bardy and productive. Fruits very young. For cooking and market mie of the best. June. English Morello-Medium size, dark red, acid, late; dwarf. Very hardy early bearer. July.

Large Montmorency-Fruit large, bright red, fine flavor; very bardy and immense bearer. Season a little later than Early Richmond.

\section{PLUMS--European}

50 cents each, $\$ 5.00$ a dozen, $\$ 30.00$ per hundred

Fellenburg-(1talian Prune)-Very large, rich dark purple, flesh juicy and good, rather coarse, freestone: tree spreading, productive. September.

German Prune-Medium size, dark blue, juicy, rich. Tree upright, vigorous and productive. September.

Reine Claude-Large, yellowish green, juicy, melting, sugary, rich flavor. Septemoer.

\section{AMERICAN}

Bradshaw-Very large, purple: juicy, excellent quality. Tree erect and vigorous, productive. August.

Imperial Gage-Medium size, yellow, juicy, ricb, déicious, productive, strong grower. August.

Lombard-Medium, violet red, juicy, pleasant and good. Immensely productive, hardy. August.

\section{JAPANESE AND HYBRIDS}

Abundance-Fruit large, showy and beantiful. Color amber turning to a rich, bright cherry red, highly perfumed. Flesh light y'ellow, juicy, tender, and delicious; freestone. The tree is a strong upright grower, immensely productive. Season early.

Burbank-Flesh, yellow, firm, tender and very juicy, rich, sweet and aromatic, Very productive. Tree spreading and hardy. One of the best. Medium. Wickson-Large, color carmine with a heavy white bloom; stone small; flesh fine, firm, sugary and delicious. Picked green, will ripen and color perfectly and keep two weeks or more after ripening, making it an excellent market plum. Tree upright grower and productive.

\section{PEACHES}

30 cents each, $\$ 2,75$ a dozen, $\$ I j .00$ per hundred Champion-A white freestone, ripening about September $1 \mathrm{st}$. Delicious, sweet, rich and juicy, skin creamy white with red cheek, strikingly handsome. It is hardy, productive, early, largest size and highest flavor.

Crawford's Early-Very large, yellow, rich, sweet, luscious; free. Sept. Crawford's Late-Very hardy, large, yellow, rich, sweet; free. September. Elberta-Takes the lead for beauty, size and quality. One of the hardiest, as large or larger than Crawford's Early, and its equal in heauty and flavor. One of the finest yellow freestone peaches. Fruit yellow with red cheek fiesh yellow, juicy, good quality; ripens slightly later than Early Crawford.

Fitzgerald-A native seedling, as large or larger than Crawford; freestone, very best quality. A heavy bearer, fruiting very young, almost invariably the second year after planting. Hardy. Ripens just afier Craw ford's Early.

Greensboro-Lerger and earlier than Crawford's Early, and nearly freestone, It is colored beautifully with crimson and has 2 yellowish cast; the flesh is white and of good flavor. The peach is large, many specimens measuring eight to nine inches in circumference. Productive. 


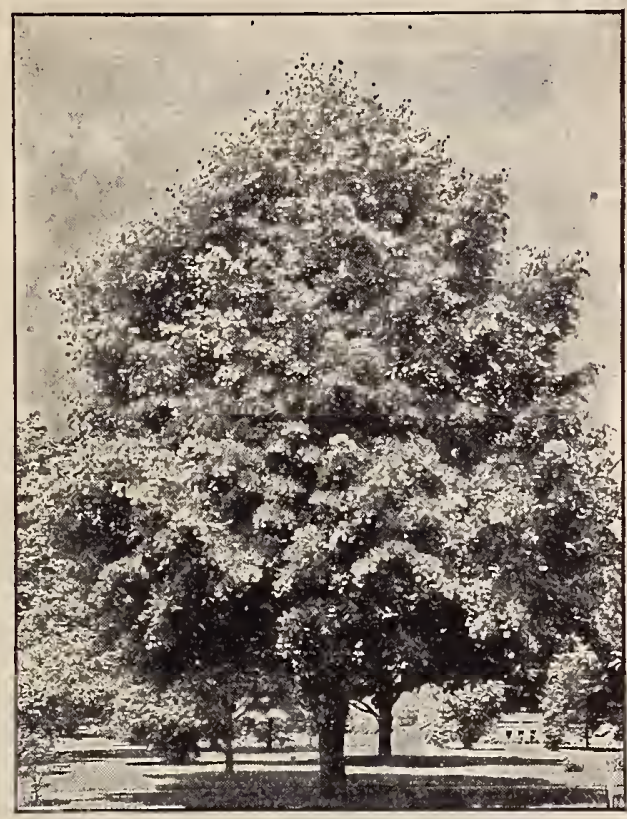

AMERICAN LINDEN

\section{ORNAMENTAL TREES}

Beech, Purple leaf.

Each. Dozen.

Birch, Cut-leaved Weeping

Catalpa, Speciosa

Catalpa, Bungei.

Crab, Bechtel's Double-flowered (American)

Dogwood, White-flowering

Dogwood, Red-flowering.

Elm, American White.

Elm, Camperdown Weeping

Horse Chestnut.

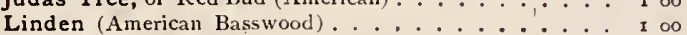

Linden (European) . . . . . . . 75

Magnolia Acuminata.

Magrolia Conspicua.

Magnolia Soulangeana

Magnolia Speciosa

Maple, Norway

Maple, Schwedler's.

Maple, Silver-leaved..

Maple, Sugar

Maple, Weir's Cut-leaved.

Mountain Ash, (European)

Mountain Ash, Oak-leaved .

Mountain Ash, Weeping

$\$ 100 \quad \$ 10$ 00

Oak, Pin.

Poplar, Carolina

Arbor-Vitæ (Tbuja Occidentalis)

\section{EVERGREENS}

Arbor-Vitæ, Douglas' New Golden

Arbor-Vitæ, Pyramidalis

Juniper, Irish

Spruce, Colorado Blue, two feet

Spruce, Colorado Blue, I2 to 18 inches

Spruce, Norway $\begin{array}{rl}\$ 10 & 00 \\ 7 & 00\end{array}$

700

10 oc

700

1500

800

ro on

Io 60

800

1900

1900

I9 on

Io on

I5 $\infty$

60

Io 00

800

700

1000

[3 00

600

600

The prices on all Trees include packing, but the purchaser is to pay the express or freight charges. Not less than six trees at the dozen price.

\section{INSECTICIDES AND FUNGICIDES}

Note-Liquids and poisonous powders cannot be sent by mail. Directions for using printed on each package.

Black-Leaf 40 (Liquid), A highly concentrated solution of Tobacco. Recommended by Experiment Stations for black Aphis and sucking insects of all kinds. Spraying directions on each package. $1 / 2 \mathrm{lb}$, , making $47 \mathrm{gal}$, of wash , 85 cents : $21 / 2$ lbs, making 240 gals. of wash, $\$ 3.25$.

Bordeaux Mixture. (Liquid). For fungous diseases. Directions for using on can. Pint, $30 \mathrm{cts}$.: quart, $50 \mathrm{cts.}$ : gal., \$1.50; charges not prepaid.

Bug Death. For potato bugs and blight; contains no arsenic; does not

wash off. In comparative tests made on our farms last season Bug Death headed the list, not only as an insecticide, but kept the plants in a healthier condition and actually increased the yield over all others, while the potatoes when dug were healthier, contained more starch, and kept better than otbers. I-lb. package, I5 cents; 3 -lb, package, 35 cents; 5 -lb, package, 50 cents: $121 / 2$-lb. package, \$1.00; 100-lb. keg, \$7.50; charges not prepaid.

Dickey's Duster. For applying not only Bug Death but any other insecticide in powdered form, 25 cents each; charges not prepaid.

Dalmatian Insect Powder. The true "Persian" insect powder Ýlb., 20 cents: $1 / 2 \mathrm{lb}$., 35 cents; lb., 55 cents ; charges paid. Hellebore. Pure and fresh : used largely for currant worms, etc.

Kerosene Emulsion. For scale insects, aphis, etc. Quart, 50 cents; gal., $\$ \mathrm{x} . \infty 0$; charges not prepaid.

Lime Sulphur Solution will destroy San Jose Scale, Oyster Shell Bark Louse, Scurfy Scale and all other sucking insects, such as Spiders, Lice, Aphides of all kinds, at the same time Fungus spores of Apple Scab, Peach Rot, Leaf Spot, etc., if applied in the fall immediately after the leaves drop, or in the spring before the buds open. Use in proportions I gal. to 40 gals, water. Quart, 25 cents; gal., 75 cents ; 5 gals., $\$ 2.25$; ro gals., $\$ 3.75$ : charges not prepaid.

Nicofume. A tobacco-paper insécticide for fumigating only. Prices; small sizes ( 24 sheets), 75 cents : medium size (144 sheets), $\$ 3.50$; large size (288 sheets), $\$ 6.50$ : charges not prepaid.

\section{STICKY BANDING FOR TREES}

To catch Insects and Caterpillars tbat crawl up from the ground to reach the foliage. Particularly valuable for catching Elm Tree Beetle and Larvae. A space about two inches wide is smoothed on the bark and Sticky Banding put on this smooth surface, making an application one-sixteenth of an inch thick. I-lb. cans, 30 cents each; 3 -lb. cans, 85 cents each; charges not prepaid,
Nicofume Liquid, $1 / 4$ pint, 50 cents; pint, $\$ 1.50$; charges not prepaid.

Nicoticide. (Liauid). Can be used either for fumiganng or spraying : $1 / 4$ pint 70 cents; $1 / 2$ pint $\$ 1.25$; pint, $\$ 2.50$ : quart, $\$ 4.50 ; 1 / 2$ gallon $\$ 8.50$ I gal., $\$ 15.00$; charges not prepaid. Lamps, complete, $50 \mathrm{cts}$, postpaid.

Nikoteen. Thirty per cent. strength, for spraying. Strongest, purest and economical. Death to Aphis or Green Fly, Red Spider, Mealy Bug, Thrip and many other forms of Flower, Fruit and Vegetable Pests. I-pint bottle $\$ 1.50 ; 2$-ounce bottle, 40 cents.

Slug Shot. Non-poisonous powder for Potato Bugs, Cabbage Lice and Worms, Currant Worms, etc. 5 lb. package, 30 cents : charges not prepaid.

Sulpho-Tobacco Soap. Used as a wash for roses, trees, and house plants. Very effective for insects on animals. 3-oz. cake, 13 cents; 8-oz. cake, 30 cents ; postage paid.

Tobacco Dust (The Black Stuff). Per lb, 25 cents; postage paid. Vick's Excelsior Insect Exterminator. Will destroy-Striped Bugs, Cabbage Lice, Green Cabbage Worms, Potato Bugs, Aphis, Squash Bugs, Cockroaches, etc; 50 cents per pound, by mail. In lots of five pound or over, 35 cents per pound by express at expense of the purchaser. Best applied by mieans of the bellows we have constructed for that purpose. Eight-inch Bellows, \$1.50. Twelve-inch Bellows. \$1.75; charges not prepaid. For use in conservatories and for hotse plants we offer a small zinc Bellows, in two sizes. No. 1 , with one ounce of Exterminator, 30 cents, postage paid. with four ounces of Exterminator, so cents, postage paid.

Whale Oil Soap. Used as a wash for roses, trees, and plants affecter with insects: $1 / 2 \mathrm{lb}$. box, 25 cents ; I lb. box, 40 cents; postage paid. Special price on large quantities.

\section{SCALECIDE}

Used for the destruction of the San Jose Scale. Dilute at the rate of one gallon Scalecide to 20 gallons of water. Scalecide does not clog hose, nozzle or pump, and is pleasant to use. 5o cents per qt.; $\$ 1.25$ per. gal.; $\$ 4.00$ per 5 हals. Charges not prepaid. 


\section{Miscellaneous Supplies}

Bellows. For applying dry insecticides. Hand-made throughout from seasoned wood and best quality sheepskin. Eight-inch, \$1.50; I2 in., \$1,75. Charges not prepaid.

Dibbles. Used in transpalnting, steel point. Each, 50 cents, postpaid; 35 cents, not postpaid.

Farm Record Book. Thirty-two pages. Practical. Does not require a bookkeeper. Enables the farmer to keep complete records of all farm operations-labor, cost of crops, poultry, stock breeding, etc., ro cents.

Farmogerm. It is always profitable and often necessary to inoculate seeds of Alfalfa, Clover, Peas, Beans, Cowpeas, Soy Beans, Sweet Peas and, other Leguminous plants. Unless the right kind of bacteria are present on the roots the plants are unable to gather nitrogen from the air. Farmogerm is a standard preparation; has been thoroughly tested. In addition to increasing the yield of legumes, fertilizer value equivalent to $\$ 30.00$ per acre, may be deposited during their growth, for succeeding crops, In bottles. Easily applied to the seed at the time of sowing. Be sure to state for what crop Farmogerm is wanted.

Garden size, $1 / 4$ acre, 50 cents; acre-size, $\$ 2.00 ; 5$-acre size, $\$ 9.00$.

Grass Shears. Best quality steel. 75 cents, postage not paid.

Grafting $\mathrm{Wax}$. $1 / 4 \mathrm{lb}$., I5 cents; $1 / 2 \mathrm{lb}, 25$ cents; lb., 40 cents, postpaid.

Garden Trowels. Solid steel, best grade only, 30 cents, not postpaid.

Labels. Wooden: painted. Charges not prepaid.

$31 / 2$ inch, pot, per $1000 \ldots 0.756$ inch, pot, per 1000

4 inch, pot, per rooo... $90 \quad 8$ inch, pot, per 1000.

4 I/2 inch, pot, per rooo . I.00 $3 \frac{1}{2}$ incb, tree, copper wired perm 4.00

5 inch, pot, per 1000 ... 1.255 inch, notched, per 1000... 2.25

Potting Soil. Especially prepared and sifted, per bushel, 75 cents'; bbl., \$1.75; charges not prepaid.

Pruning Shears. Charges not prepaid: 10-inch Wiss, genuine, \$2.50; g-inch W'iss, genuine, $\$ 2.25$.

Raffia. For tying, per lb., 20 cents; 5 lbs., 80 cents; 10 lbs., \$1. so charges not prepaid.

Sprinklers. Tyrian. Rubber, made with a perforated detachable top valuable for window gardening, bouquet sprinkling, dampening clothes, etc.; postpaid.

6-ounce size, straight neck .

6-ounce size, bent neck

8-ounce size, straight neck

8-ounce size, bent neck

So 75

Weeders. Claw, 25 cents; Hazeltine, 40 cents; Lang, 30 cents: postage paid.

\section{BASKET MAKING MATERIALS}

Raffia. The inner skin of a palm found in Madagascas. Raffia is very fly weaving into fancy baskets, boxes and mats. In its cor basket work va rious colors are used: our list is complete and embraces the following:

No. 3-Indian Red No. 14-Sage Green Nio, 8-Pink

No. I2-Ligbt Orange No. I7-Emerald Green No. 10-Brown

No. 5- Vellow No. 6-Dark Navy No. o-Black

No. 16-Bright Jellow No. 7-Red No. 13-Bright Green

- Christmas Red

PRICES ON BASKET MATERIALS Postage Paid

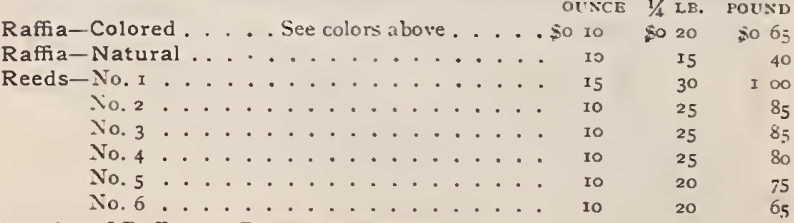

Samples of Raffia and Reeds on application.

\section{BOOKS ON BASKETRY}

Basket-Making. By T. Vernette Morse. 32 pages, illustrated with ro6 work. ing designs. A condensed work valuable to the beginner. Postpaid 25 cents. How to Make Baskets. By Mary White. 200 pages, cloth bound, finely illustrated with working designs and half-tone plates. The best work on the subject we have seen. Postpaid, \$1.10.

\section{KNIVES BUDDING AND PRUNING}

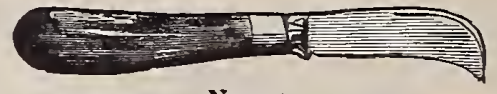

No. II7

Pruning. No. II7 - I blade, folding, cocoa handle, round end... . .80

No. $80 \mathrm{x}$ - $\mathrm{r}$ blade, folding, cocoa handle ...... . . . 65

No. 923 - x blade, folding, stag bandle ....... 1.00

No. 928 - I blade, folding, stag handle . . . . . . 1.25

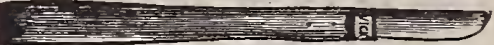

No. 728

Budding. No. $7^{18-}$ r blade, open: cocoa handle ........ . \$o.25
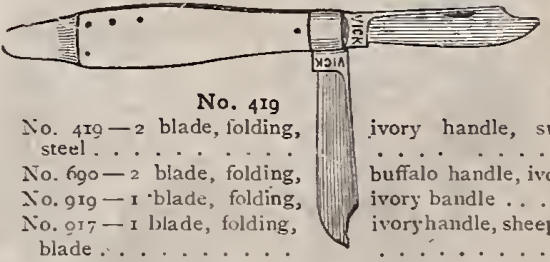

ivory handle, superior

" No. $4 \mathrm{Ig}-2$ blade, folding,

No. roo- 2 blade, folding

No. 9 rg - I blade, folding.

blade

........ . 51.25

buffalo handle, ivory tip 1.00

ivory bandle ...... I. 15

ivors handle, sheep's-íoot

$\mathbf{1 . 3 5}$

\section{FERTILIZERS}

Clay's Fertilizer. A popular English concentrated fertilizer for forcing greenhouse plants and vegetables; also used on bouse plants, about one teaspoonful to each plant. Per lb., 20 cts.; 5 lbs., 75 cts.; 10 lbs., \$r.25; 28 lbs., \$2.25; 56 lbs., \$4.00; 112 lbs., \$7.25; charges not prepaid.

Nitrate of Soda (Chili Saltpetre). The best and cheapest form of Nitrogen for plants. Highly concentrated and immediately available. Nothing like it to make plants grow. Price subject to market changes. 3 lbs., $30 \mathrm{cts}$; 5 lbs., 50 cts.; rolbs., 75 cts.; 25 lbs., $\$ 1.50$; 100 lbs., $\$ 4.00$; charges not prepand.

Pure Raw Bone Meal. I lb., ro cents, or postpaid, 25 cents; 5 lbs., 30 cents; 10 lbs., 50 cents; 25 lbs., \$1.00; 50 lbs., \$1.75; s00 lbs., \$3.00; charges not prepaid.

Peruvian Guano. In $200 \mathrm{lb}$. bags only ; per bag, $\$ 5.00$; per ton, $\$ 40.00$

\section{Pulverized Sheep Manure}

It is Convenient. Being thoroughly dried and finely ground. Pulverized Sheep Manure is in a convenient form for use on the lawn, in the garden, in the greenhouse, or for potting soil. Most of the weight has been removed in drying.

It is Natural. A pure animal fertilizer. No chemical change or loss of plant food occurs in drying and grinding. Adds organic matter to the soil by nature's own method.

It is Inoffensive. Unequalled for the lawn. Is a top dressing of stable manure, without any unsightly appearance or offensive odor.

There is No Risk. Contains no acids or chemicals to burn the sprouting seeds or roots of plants. May safely be used wherever stable manure would be desirable, and without inconvenience.

On the Lawun. The first shower, or watering, following an application of Pulverized Sheep Manure, produces a luxuriant dark green rrowth. The insoluble particles, gradually decaying, feed the grass roots for a long time, so that the effect is lasting.

We have used Pulverized Sheep Manure on our own farm quite extensively for Field Crops, with excellent results. For this purpose we use a grain drill as for commercial fertilizers.

In the Gardin Pulverized Sheep Manure is convenient; it furnishes plant food in the best form for growing plants of all linds; and it adds organic matter, or humus, to the soil, thus keeping it in a good mechanical condition. Commercial fer, tilizers cause the soil in time to become hard and dry.

Price: 6 lbs., 35 cents ; 25 lbs., 75 cents; 50 lbs., $\$ 1.25$; Ioo lbs., \$2.00, not prepaid. 


\section{Auto-Spray No. 40}

Equally well adapted as a general purpose sprayer for trees, plants, shrubs, vines, etc., or for applying whitewasb and cold water paint. The tank is made of either brass or galvanvanized iron, as ordered. The pump and large air-cha mber are made of heavy brass, and the pump is fitted with a special graphite packing which can be easily: adjusted. The agitation is mechanical and effective.

We offer this machine as the best all-around size and equipment, in lever handle high pressure punps, for small orchards and general work. It can be carried about, by the handles or mounted on a wheelbarrow. Each machine securely cratfeet an high-grade hose, eight feet of extension, stop cock and Vermorel nozzle. Shipping weight, $45 \mathrm{lbs}$.; net $w^{\prime}$ ght, 33 lbs. Auto-spray No. 40-A.

Brass tank; capacity, eigbt gallons A u to-Spray No. $40-\overline{\mathrm{B}}$. Galvanized tank; capacuy, eight gallons . Auto-Spray No. 40-C Brass tank, mounted on a 20 -inch one-wheel truck; c a pa cit y, 12 gallons

Auto-Spray î. $40-\dot{D}$ Galva nized tank mounted on a zo-inch one-wheel truck: ca pacity, I2 gallons. . 14.40

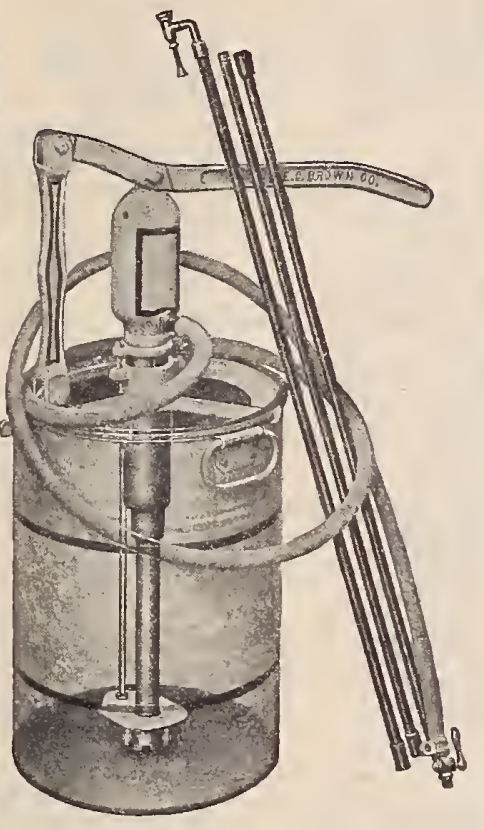

\section{Non-Clog Atomic Nozzle}

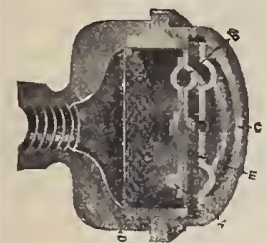

The most valuable nozzle on the market. Positively the only nozzle that will not clog despite the claims of other manufacturers. Its good points will appeal to any practical orcbardist. Can be adjusted by a simple mechanism to throw from a fine spray eighteen inches from tbe nozzle mouth,to a concentrated form throwing twenty feet Has a capacity of two, three or four point Vermorel, according to the disc used, each nozzle being furnished with four discs. A special feature is the patented screen through which the solution passes before entering the nozzle and absolutely preNet price, $\$$ r.oo brass. Also fitted with standard $1 / 4$ inch pipe thread.

\section{Auto-Spray No. 1}

\section{Capacity Four Gallons of Solution}

The Auto-Spray. No. I is the best corn. pressed air sprayer made. Strongly built and guaranteed to be satisfactory and without defect. Will handle all solutions including whitewash, and can be used in all kinds of work. Tank of heavy brass or galvanized steel. Seamless brass pump 2 inches in diameter. The pump is locked air tight to the tank by means of a simple sliding cam. Tbis locking device is superior to that on any other spray er. There are no screw connections to wear out and become leaky. All parts are instantly accessible and easily replaced. Each machine equipped with 2 feet of $1 / 2$-incb hose, nozzle for fine spray, cap for solid stream and either stop-cock or our patented self-cleaning shut off ("auto-pop") as ordered.

Auto-Spray No. I-A-Brass tank with stop-cock.
Anto-Spray No. I B-C Brass tank with $\$ 6.75$ auto-pop

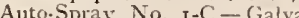
with stop-cock

Auto-Spray No. I-D- Galvanized tank

with auto-pop

Brass Extension, 2 feet.

Brass Elbow

Brass Strainer.

\section{Auto-Spray No. 37 \\ Continuous Sprayer}

Compact design. Will bandle all solu$t$ ions. The entire unscrewing the front

cap, permitting the syphon tube to be

withdrawn should it become clogged. Fitted with two spray caps, one straight, and the other at an angle for reaching the under side of broad

leaves. Will spray with tank at any angle. So-

lution does not come iu contact with pump cylinder.

Auto-Spray No. 37-A-One quart, all tin

Auto-Spray No. 37-B-One quart, Galvanized reserviois

Auto-Spray No. 37-C-One quart, Brass reservoir

Auto-Spray No. 37-D-Galvanized tank, one-half gallon.

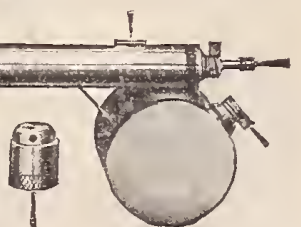

Auto-Spray No. 37-E-Brass tank, one-half gallon.

\section{Ornamental and Flowering Plants for Special Purposes}

For Constant and Brilliant Bloom. African Daisy, Ageratum, Sweet Aly'ssum, Antirrhinum, Asters in all varieties, Calliopsis, all the dwarf Cannas, Centaurea, Eschscholtzia, Gaillardia, scarlet Geraniums, Marigold, Nasturtium, Pansy, Petunia, Phlox Drummondii, Portulaca, Salvia, Scabiosa, Sweet Peas, Verbena, Double Zinnia,

Low-Growing Plants for Masses of Color. White-Sweet Alyssum, white Ageratum, white Candytuft, Vick's white Pllox. Drummondii, white Verbena.

Blue-Ageratum, Heliotrope, Lobelia, blue Verbena.

Red-Carmine and Crimson Candytuft, Geranium, Phlox Drummondii, Scarlet, and Phlox Dwarf Fireball, Poppy, Verbena.

Yellow-Gaillardia, Eschscholtzia, French Marigold and especially the variety Tagetes signata pumila, and Nasturtium Lady Bird.

Dwarf Plants for Edgings and Borders. Ageratum, Alyssum, Dwarf Candytuft, Coleus, Douhle Daisies, Golden Feather, Little Gem Feverfew, Heliotrope, Lobelia, Mignonette, Myosotis, Pansies, Phlox Drummondii, Pinks, Veronica, Vinca, Violets.
Hardy Plants for Cemeteries. Anemone Whirlwind and Japonica, As. tilbe Japonica, Achillea the Pearl, Hardy Candytuft, Eulalias, Hemerocallis flava, Hydrangea arborescens, Hydrange paniculata grandi. ra, Lilies, Lily of the Valley, Day Lily or Funkia alba, Chinese Peonies, Polyast tha Roses, Rose Madame Plantier, Spirea Van Houttei, Vinca minor.

Fragrant Flowers. Asperula odorata, Sweet Alyssum, Candytutt, Carnation, Clematis paniculata, Honeysuckle, Heliotrope, Lily of the Valley, Lily, Mignonette, Nicotiana affinis, Pansy, Sweet Peas. Pink, Rose, Sweet William, Ten Weeks Stock, 'Tuberose, Verbena, Wallflower.

Climbing Plants. Ampelopsis, Aristolochia, Adlumia cirrhosa, Cobnea, Cypress Vine, Clematis, Cardiospermum (Balloon Vine), Chinese Matrimony Vine,Cinnamon Vine, Dolicbos, the Gourd Family, Humulus Japonicus, Honeysuckle, Morning Glories and Ipomøas, English Ivy, Maurandya, Perennial Peas, Trumpet Vine.

Plants for Window Boxes, Vases and Baskets. Ageratum, Alyssum, Abutilon, Begonia, Canna, Cobœa, Coleus, Dracæna indivisa, Fucbsias, Grevillea, Geraniums, Heliotrope, German Ivy, Lobelia, Lantana, Mignonette, Mim. ulus, Myosotis, Maurandya, Manettia Vine, Madeira Vine, Nastırtiums, $\mathrm{Ox}$. alis floribunda, Portulaca, Petunia, Schizanthus, Thunbergia, variegated forms of Vinca major, Veronica, 


\section{Index of Articles in This Catalogue}

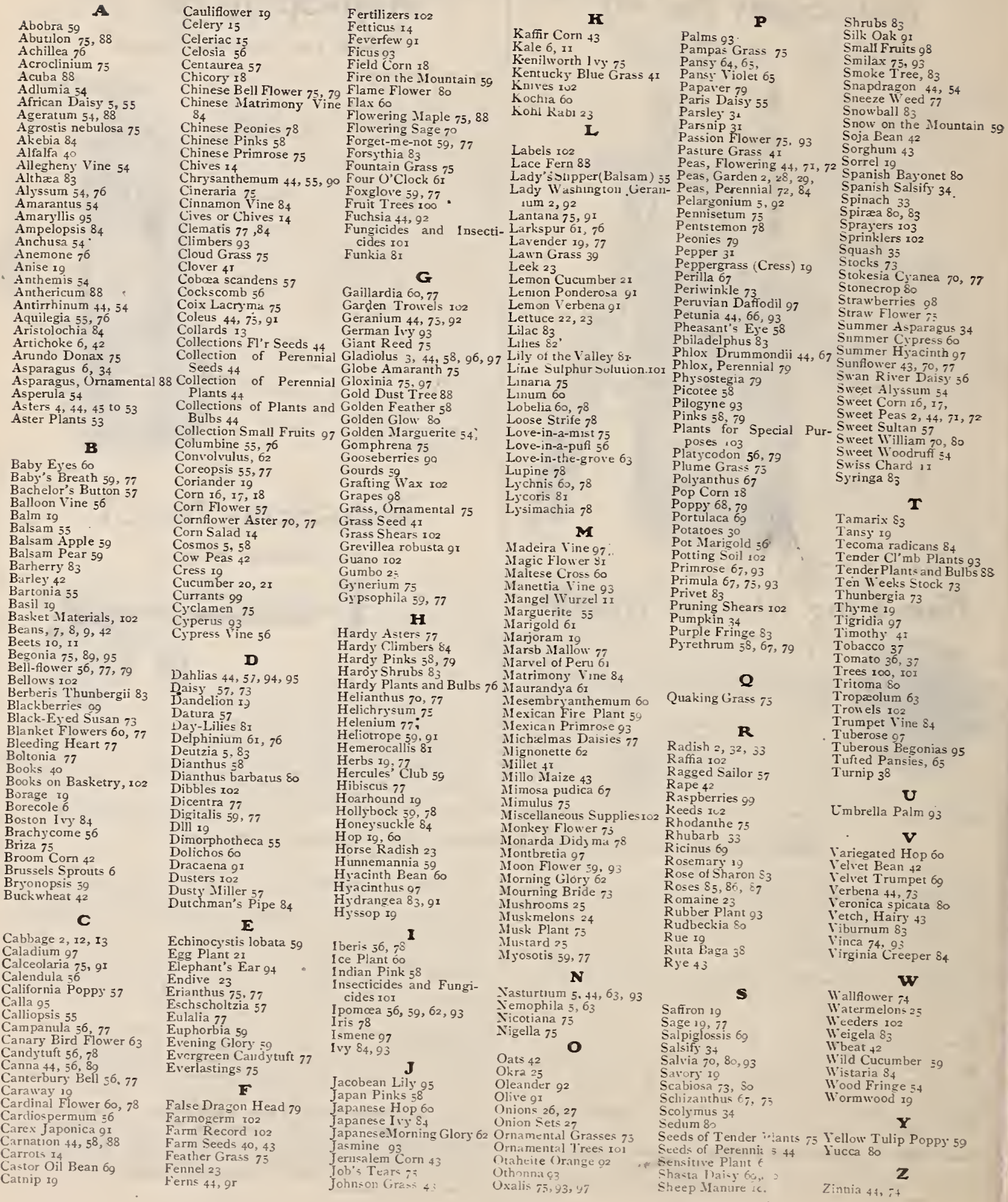



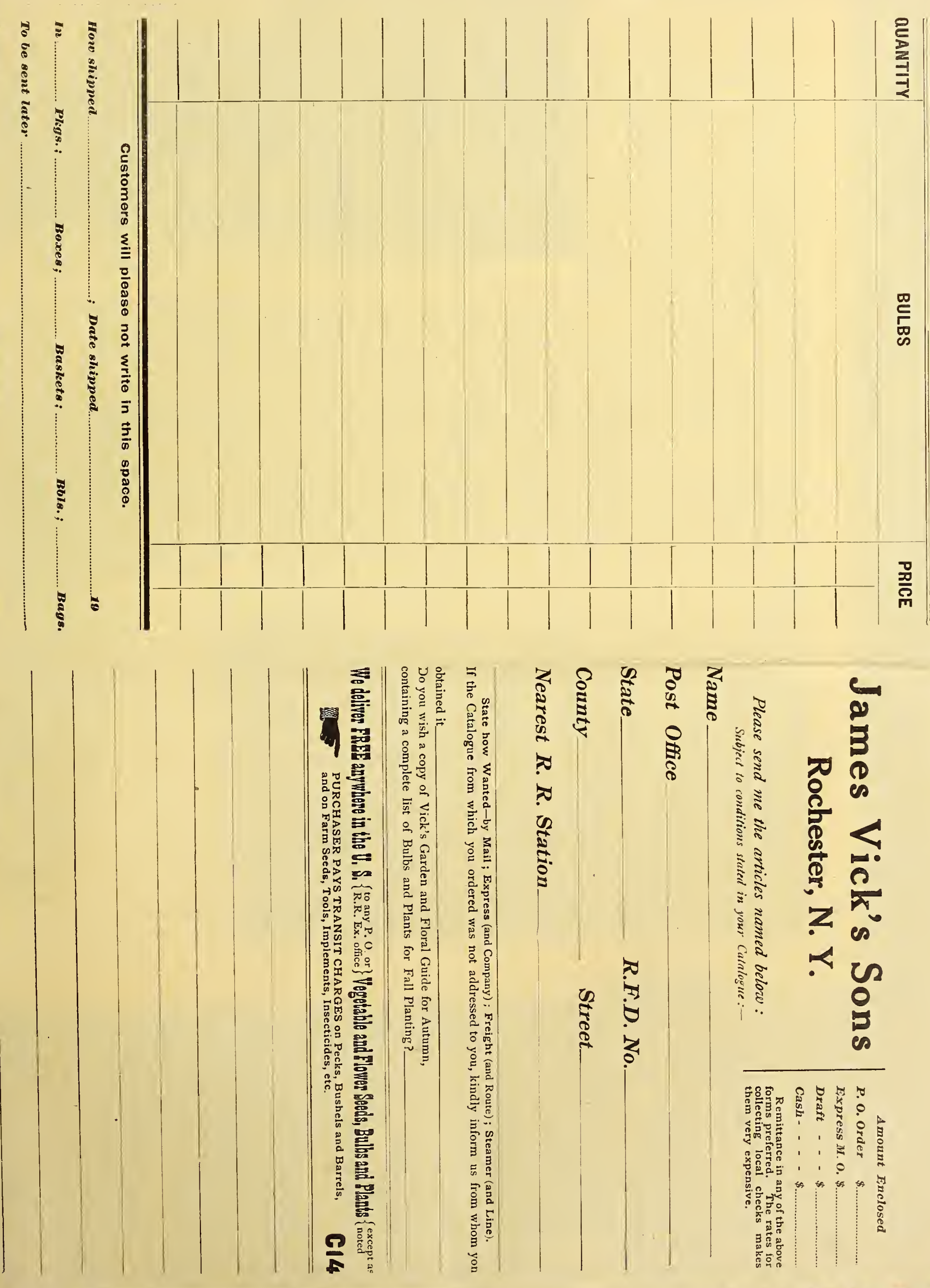

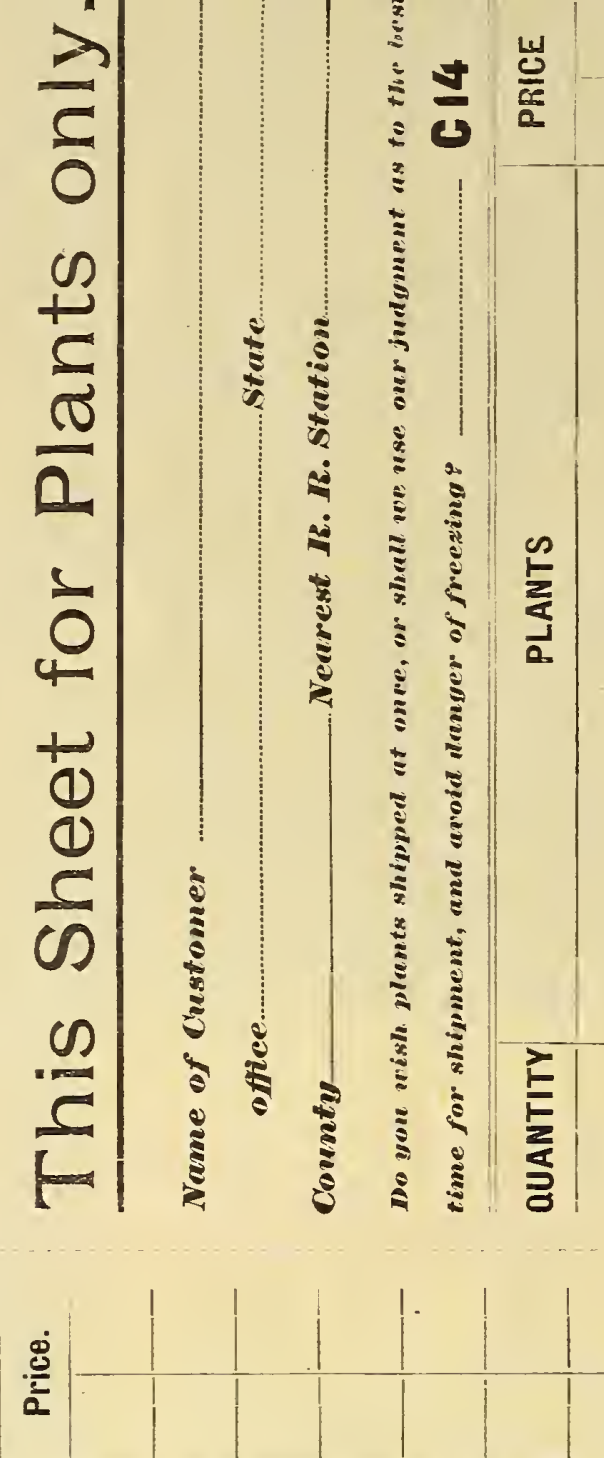

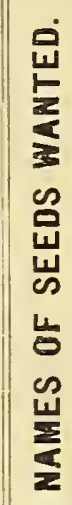

桠

N

g.

$\frac{g}{2}$

$\frac{\dot{s}}{\sigma}$

:

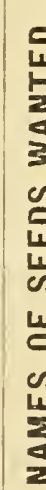

$\frac{5}{\frac{5}{a}}$

o

s

.

$\sqrt{\frac{g}{a}}$ 


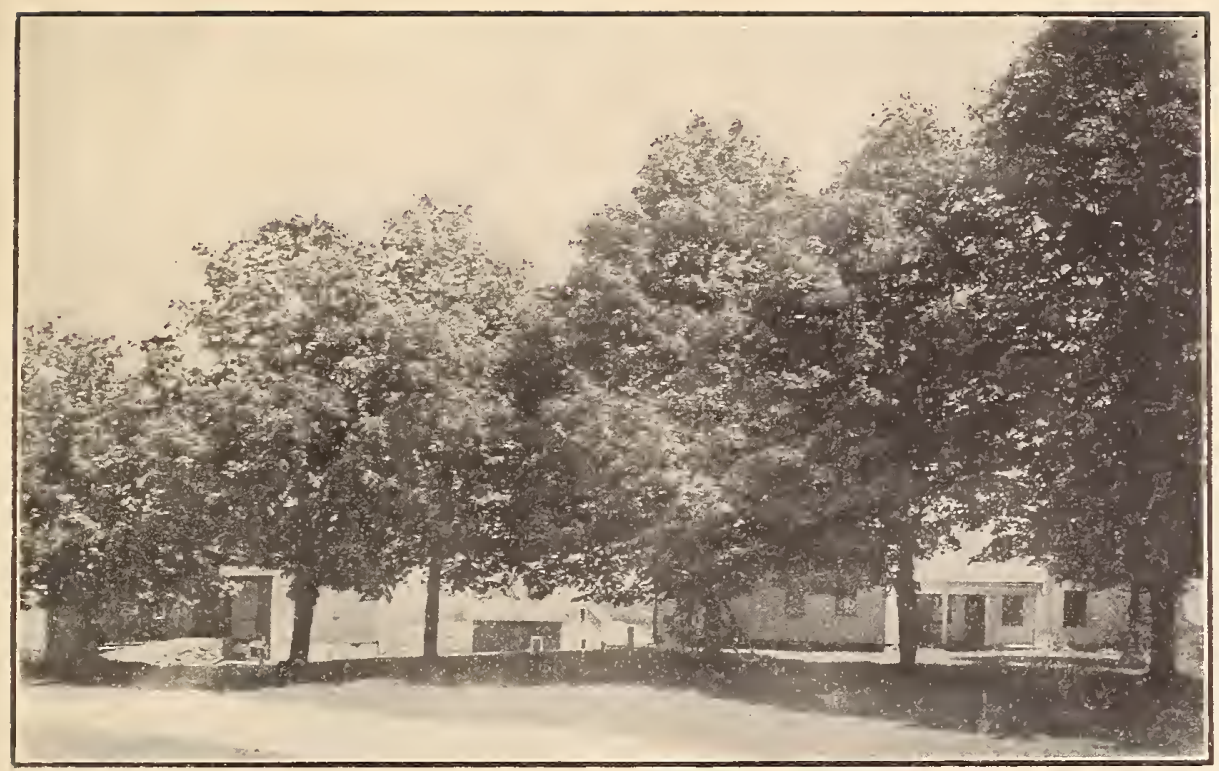

THE first view on this 1 page shows the entrance to one of our seed farms which we call "The Orchard Farm." Many people in this section of the state rall it "The State Orchard Farm" for the reason that it contains an orchard which has been operated for a number of years by a New York State Experimental Station and is under lease for several more, as a model and experimental orchard. By many experts it is considered the most perfect orchard of its size as regards location, soil conditions, health, vigor and shape of trees, and average productiveness. The Experiment Station keeps an accurate record of every kind of expense in connection with it, the results of all the experiments, and the total yield from every tree. Apples from this orchard have uniformly sold for a price considerably higher than the general market. Although this season has been unfavorable for apples in this section of the country, our orchard produced a large crop of excellent quality. They have already been sold by the state at a very handsome figure. It has occurred to us that many of our customers living in towns or cities, or any section where apples are not plentiful, would like us to ship one or more barrels of apples next fall. It is too early to make definite arrangements now, but by the time our fall catalogue of 1914 is issued we will practically know about the crop and what prices to obtain. If any of our customers are interested in this matter we will be glad to have them write us about August or September next.

The other view on this page represents a part of a group of the Rochester Florists' Association, which organization apparently satisfactorily accomplished two things: holding a picnic and inspecting our flower fields. Every year our farms are visited by a large number of people, the number increasing every season. While a good many of them are florists and seedsmen who come long distances to study the varieties of Asters or other flowers in which they are interested, the larger number of our visitors come by trolley, or motor, simply to enjoy the glorious coloring and magnificent expanse of one field of flowers after another.

Visitors are always welcome. It is indeed a great pleasure to us to have thousands of people enjoy the glorious spectacle our farms present in the late summer and autumn time. Our trial grounds show a great variety of flowers grown under ordinary outdoor soil conditions. These alone furnish opportunity for study, and are a great source of pleasure to every visitor; while our main crops of Asters, Phlox, etc., furnish a siectacle which, for becuty and grandeur, are not surpassed by any similar sight in America.

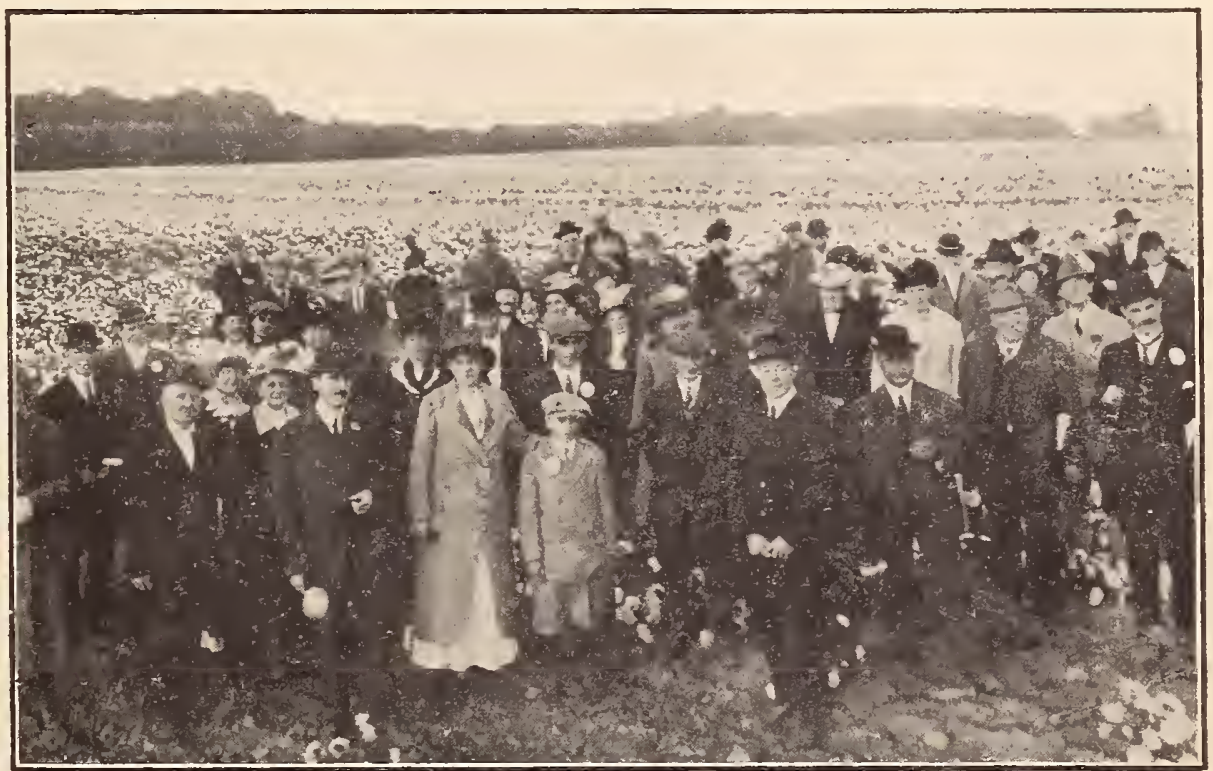




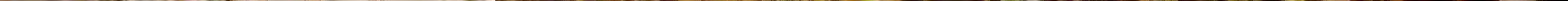

